


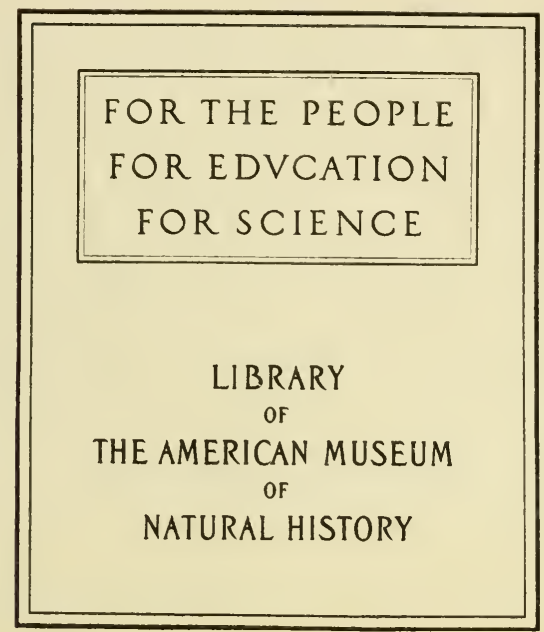





\section{The Natural History of South Africa} Mammals. 4 Volumes

The Monkeyfolk of South Africa

The House Fly: A Slayer of Men

$$
\text { Publishers : }
$$

Messrs LONGMANs, GREEN, AND CO. 39 Paternoster Row, London

\section{The Snakes of South Africa:}

Their Venom and the Treatment of Snake Bite Snake Bite and its Scientific Treatment

$$
\text { Publisher : }
$$

Mr T. MASKEW MILLER, Adderley Street, Cape Town

The above-mentioned Works are all Profusely Illustrated

Extract from Letter by R. Roycroft, M.B., C.M., District Surgeon, Greytown, Natal :

"I take this opportunity to express to you my thanks for the many hours of genuine pleasure you have given me by the reading of your so charmingly worded works. It is very seldom that a scientist combines the two factors : ( I) Knowledge; and (2) the skill of being able to present that knowledge in language "understandable of the people.", 




\section{THE NATURAL HISTORY OF SOUTH AFRICA}

VOL. I. 
23-43762-Dec. 14.

i.

Made in Great Britain 
TO THE

Loving Companion and Helpmate in my Labours MY WIFE

THIS BOOK IS AFFECTIONATELY DEDICATED 


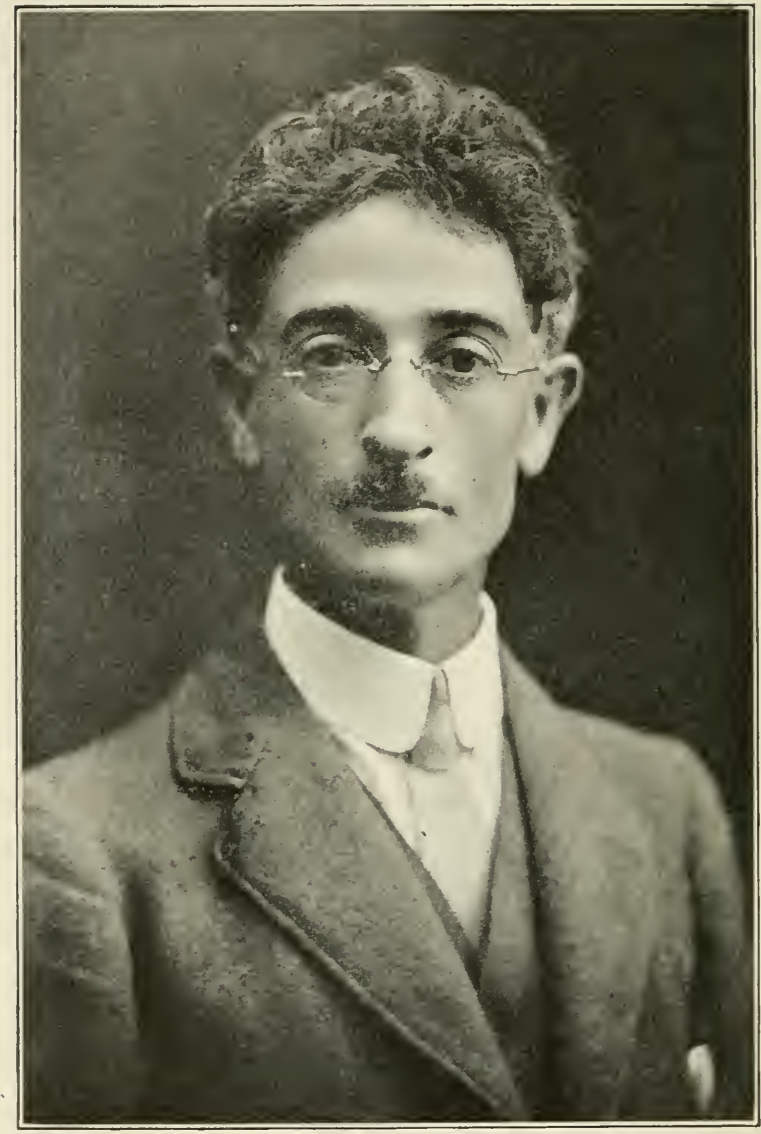

THE AUTHOR

(I922) 


\section{PREFACE}

In the presenting of these volumes on the birds of South Africa, it has been my endeavour to create in the minds of my readers a love and a keen appreciation of our beautiful and useful allies.

From my earliest youth I have made an intimate study of the creatures of mountain, veld, forest, and stream in their native haunts. The results of some of these studies have already been published in book form in the "Natural History of South Africa" and "Snakes of South Africa." My intention was to have published these volumes at an earlier date, but, owing to unforeseen circumstances, their publication has been held over.

The results of several years of research and study of the birds of South Africa were recorded in a number of diaries. These records were lent to a naturalist friend with permission to take notes from them. Alas! he lost them all. It was a sad loss to me, resulting in further years of investigation.

The first volume deals chiefly with the economic side of bird life. There is much spade work and great battles yet to be fought by the human race against the adverse forces of Nature which retard the 
spread of the human race over earth's fair surface. Our most formidable and ruthless opponents are the insects. It is now almost an even fight for supremacy, and unless we combine and utilise our forces more effectively and efficiently, we shall find it very difficult to secure a livelihood. A few more wars, with the inevitable disorganising of the forces employed against the insect hosts, will result in these enemies getting a strangle hold upon us. Our race may recover, but many millions will perish of starvation and insect-borne diseases. The fecundity of the insect is tremendous, and a little weakening in our offensive will bring disaster, sure and certain, upon our race. The insects are fighting for possession of the earth. It is now a case of Insect versus Man. All other forms of life have been subdued, but the insect still holds its ground, and ever and anon gains considerable advantages over us. The present production of food is not sufficient for the needs of our race. Millions live in a condition of semi-starvation; hosts actually die of hunger. With the increase of the world's population, we must have a corresponding increase in food production. By subduing the insects and keeping them in subjection we can provide food in plenty for every human being. At present a large percentage of the world's food supply is devoured by hungry insects.

In our struggle for food and life we have two great aids. Birds stand in the front rank as our allies, and cannibal insects come second in usefulness. We cannot stem the assaults of our enemies with 


\section{PREFACE}

poison sprays and other artificial appliances, supplemented by useful carnivorous and parasitic insects.

The birds alone can turn the scale in our favour.

The principal object of this book is to endeavour to show the extent of the depredations of insects, and the usefulness, nay, the necessity of birds in our fight for supremacy against the greatest enemy of the human race-the insects and allied forms of life.

In the compilation of these books I was helped by valuable field observations on the nesting habits and diet of birds by my son Vivian; also by my son Desmond with many pen and ink sketches.

\section{THE AUTHOR.}

Port Elizabeth, I923. 



\section{NOTE}

THE author and publishers both wish to gratefully acknowledge their obligations to Messrs Bernard Quaritch Ltd. for permission to reproduce the coloured plates in Layard and Sharpe's "Birds of South Africa." Plate I., Crested Eagle (Hieraaëtus ayresi), is reproduced from The Ibis by kind permission of the Committee of the British Ornithologists' Union. To Edward Howe Forbush, the Ornithologist of the Massachusetts State Board of Agriculture and the Editor of Bird Notes and Neros, for literature. Also for notes and extracts taken from the book "Birds of South Africa" by Layard and Sharpe, and "The Fauna of South Africa" (Birds) by Stark and Sclater. 



\title{
ILLUSTRATIONS
}

\author{
VOLUME I.
}

\section{COLOURED PLATES}

PLATE

I. Crested EAGLe (Hieraaëtus ayresi) - Frontispiece From The Ibis. April I9I9.

II. (I) White-FLANKed Flycatcher $\left.\begin{array}{l}\text { (Pachyprora molitor) } \\ \mathrm{R} \text { (Pachyprora privit) }\end{array}\right\}$ to face page 10

(2) PriRit Flycatcher (Pachyprora pririt)

III. BAKBAKIRI SHRIKE (Laniarius gutturalis) ,$\quad 76$

IV. ORANGE-BREASTED ROCK-JUMPER

(Chatops aurantiacus)

V. (I) GREen COUCAL (Ceuthmochares australis)

(2) West African Coucal

(Ceuthmochares cireus)

\section{BLACK AND WHITE PLATES}

The Author (1922)

Nomenclature of the Bird's Feathers

Beaks and their Uses 


\section{ILLUSTRATIONS}

(I) The Crombec Warbler's Nest ; (2) Bakbakiri Shrike, Nest, and Eggs; (3) The Little White-Eye's Nest; (4) The Large Yellow Seed-Eater's Nest; (5) The Crowned Lapwing and Eggs ; (6) The Thick-Knee's Nest

(1) Nest of Silent Bush Robin, or Fiskal Flycatcher ; (2) Nest of the Cape or Olivaceous Thrush; (3) Nest of Cape Robin Chat; (4) Nest of Bar-Throated Warbler; (5) Cape Bulbul, with Egg of Cuckoo; (6) Nest of Cape Canary

(I) Secretary Bird ; (2) White Stork

Nests of (I) Pink-Billed Weaver; (2) Black and Yellow Bishop Bird; (3) Scaly-Feathered Weaver; (4) Black-Headed Oriole

Nests and Eggs of (I) The Drongo; (2) Turtle Dove; (3) Tchagra Bush Shrike; (4) Bakbakiri Shrike;

(5) Cape Rock Thrush - - - - 55

Black and Grey Cuckoo at the Nest of a Cape Bulbul - _ 59

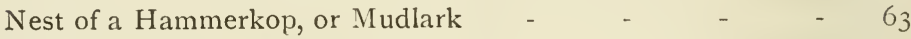

(1) Pair of Paradise Flycatchers and Nest; (2) Red-Necked Bush Pheasant's Eggs ; (3) Nest-Hole of a Woodpecker

Nests of (I) Smith's Weaver Bird; (2) With Unusually Long Entrance Tube ; (3) Spotted-Back. IVeaver ; (4) Yellow Weave

Nests of (I) Burchell's Coucal, or Vlei Loerie ; (2) Honeysucker; (3) Cape Longclaw ; (4) Quail ; (5) Stanley

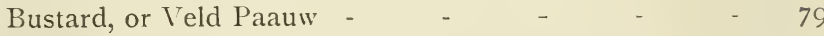

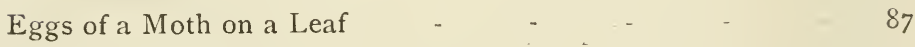

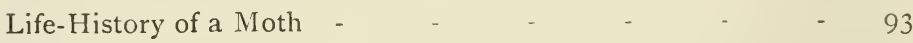

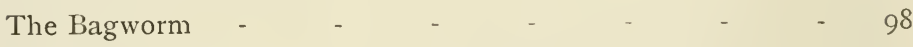

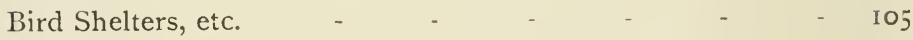

Boomslang, or Tree Snake - $\quad$ - $\quad$ - $\quad$ - $\quad$ - $\quad$ Io9

(I) Secretary Bird in the Act of Killing a Snake; (2) Nest of a Black Crow on the Top of a Telegraph Pole - _ I 5

(I) Mountain Partridge ; (2) Red-Necked Pheasant - _ II9

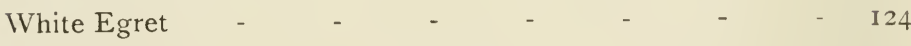




\section{ILLUSTRATIONS}

(I) A Domestic Fowl Half Skeletonised; (2) Skeleton of an Abnormal Domestic Duck

Nesting Boxes from Old Tins, etc.

Various Types of Bird Nesting Boxes

Tree-Hole and Walden Boxes

Cat-Proof Fence and other Devices for Protecting Birds - 148

Various Devices for Protection from Climbing Cats, etc. - $\quad 153$

Nesting Boxes in Position - _ _ _ - 159

The Black Crow, or South African Rook - 162

(1) The Wattled Starling, or Little Locust Bird ; (2) The Black-

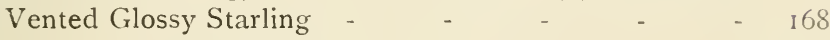

(1) Burchell's Glossy Starling; (2) Pied Starling - _ 173

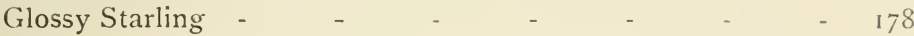

(I) The Red-Wing Starling, Spreeuw, or Rooivlerk;

(2) Verreaux's Glossy Starling - $\quad$ - $\quad$ - $\quad$ I 82

(1) Black-Headed Oriole ; (2) Golden Oriole - _ _ 187

(I) Masked Weaver Bird ; (2) Black Widow Finch ; (3) Paradise Widow Bird ; (4) Pin-Tailed Widow Bird

193

The Gape of the Night Jar

(1) Common Waxbill, or Rooibeckie ; (2) South African Ruddy Waxbill, or Robin; (3) The Dainty Scaly-Feathered Weaver -

(1) Dufresne's Waxbill, or See-See ; (2) Orange-Breasted Waxbill, or Zebra Waxbill; (3) Blue-Breasted Waxbill; (4) Grenadine, or Violet-Ear Waxbill -

(1) Taha Bishop Bird; (2) Black and Yellow Bishop Bird, or Yellow Kafir Fink; (3) Black and Yellow Bishop Bird, Nuptial Plumage ; (4) Paradise Widow Bird

(I) Sundevall's Seed-Eater; (2) Streaky-Headed Seed-Eater; (3) Seed-Eater ; (4) Cape Canary

(1) Capped Wheatear, or Schaap-Wachter; (2) The Large Yellow Seed-Eater; (3) The Golden-Breasted Bunting, or Streep-Kopje -

(I) The Cinnamon-Backed Pipit; (2) Orange-Throated Lark, Longclaw, Cape Lark or Cut-Throat Lark; (3) RedCapped Lark (Inkelde Leeuwerk) 


\section{ILLUSTRATIONS}

( I) Rufous Long-Billed Lark ; (2) Bar-Tailed Lark, or Clapart Leeuwerk -

Cape Wagtail

(I) Ray's Yellow Wagtail ; (2) African Pied Wagtail -

(I) Cape Long-Tailed Sugar Bird; (2) The Orange-Breasted Sun Bird ; (3) Greater Double-Collared Sun Bird

(I) The Black Sun Bird; (2) Immature Male; (3) MouseColoured Sun Bird

(I) The Cock Malachite Sun Bird; (2) The Female;

(3) Scarlet-Chested Sun Bird -

251

A Fiscal Shrike, or Butcher Bird

Fiscal Shrike, or Butcher Bird, with Nest and Eggs

256

26 I

(I) The Black-Headed Bush Shrike; (2) Four-Coloured Bush Shrike; (3) The Black and Crimson Shrike

(I) The Long-Tailed Shrike; (2) The Bakbakiri Bush Shrike, or Cock-a-Vick - $\quad$ - $\quad$ - $\quad$ -

(1) Lesser Puff-Back, or Snowball Shrike ; (2) Greater PuffBack Shrike, or Bonte Canaribyter

(1) Grey Cuckoo Shrike, or Blaauw Katakure; (2) Black Cuckoo Shrike ; (3) Southern Grey-Headed Bush Shrike 


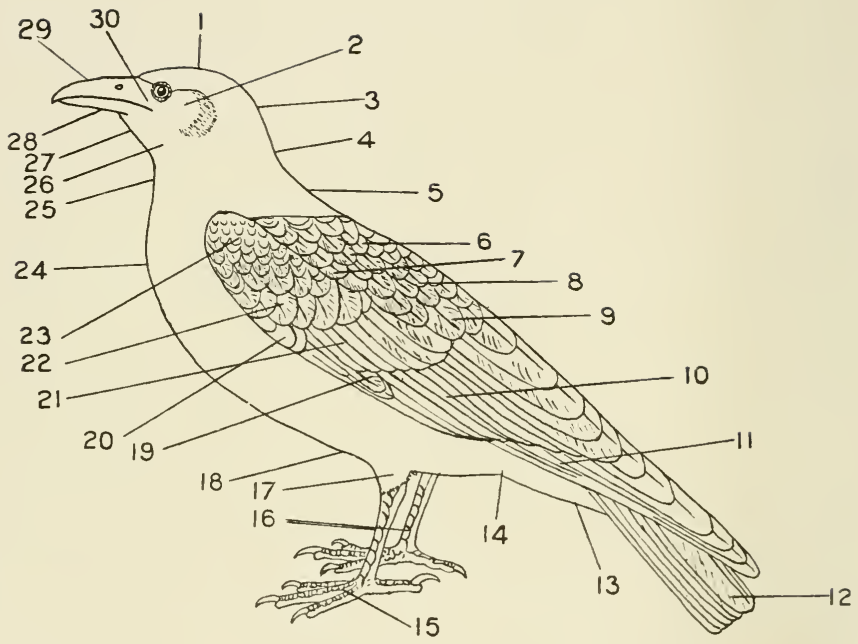

1. Crown.

2. Ear coverts.

3. Hinder crown.

4. Nape.

5. Hind neck.

6. Mantle.

7. Scapulars.

8. Upper back.

9. Lower back.

10. Secondaries.
11 Primaries.

12. Tail.

13. Under tail coverts.

14. Vent.

15. Foot.

16. Tarsus

17. Thigh.

18. Belly.

19. Primary covert.

20. Bastard wing.
21 . Secondary coverts.

2.2. Median coverts.

23. Lesser coverts.

24. Chest.

25. Throat.

26. Cheek.

27. Chin.

25. Genys.

29. Culmen.

30. Lores. 


\section{THE NATURAL HISTORY OF SOU'TH AFRICA}

\section{BIRDS}

"Think of your woods and orchards without birds!

Of empty nests that cling to boughs and beams!

As in an idiot's brain, remembered words

Hang empty 'mid the cobwebs of his dreams !

While bleat of flocks or bellowing of herds

Make up for the lost music when your teams

1)rag home the stingy harvest, and no more

The feathered gleaners follow to your door."

LONGFELLOW.

In the economy of Nature birds take a very considerable part. Throughout all forms of life, from the humble creatures which are mere spots of transparent jelly, upwards all along the line to the highly evolved sub-human animals, Nature guards against the undue multiplication of species so that those forms of life which increase most rapidly have the largest number of enemies.

Man fondly nurses the erroneous belief that he is the dominant animal upon earth. True, he has acquired a considerable measure of power and dominance, and persecutes and slays the lower animal life VOL. I. 
around him in a most brutal and unreasoning manner. Knowing no better, he destroys friend and foe alike.

The real lords and masters of the world are the insects. With his many inventions, man wages a constant warfare upon the insect army which is seeking to drive him from the face of the earth. The numerous sub-human allies which the Creator has provided to aid him in his struggle for life are doing most of the fighting. Man's puny attacks do about as much damage to the insect enemy as shooting into a flight of migratory locusts with a rifle.

Insects breed with astounding rapidity, and when from any cause their natural enemies are diminished in numbers, they immediately increase and become a plague.

Over a million species of insects are already known, and new kinds are being discovered every day. These vast, uncountable hordes live upon vegetable and animal life. If we had the power to exterminate all the natural enemies of insects, and exercised that power to the full, then, within a period of five years, the insects would have swept the entire world bare of vegetable life-yes, as bare as the Sahara Desert. Every living creature is dependent either directly or indirectly on plant life, and the world would, without it, become a barren, uninhabitable waste. Man is indeed a provokingly unreasoning animal, for he, as a general rule, does not avail himself as he should of the knowledge of his men of science. To bring about most of the reforms for the protection and general betterment of the individual and the race, it is usually 


\section{BIRDS}

necessary to employ compulsion in the form of legislation. Until the education of children takes a more practical turn, the human race will continue to blunder on and evolve to higher intellectual and spiritual planes at an exasperatingly slow pace.

Insects have hosts of enemies other than our feathered allies; but if we exterminated the native birds, the human population of South Africa would, in a few years, be reduced to a condition of starvation. The fecundity of many species of insects is staggering to the imagination of even an astronomer. For instance, one hop aphis, if allowed to breed unchecked, would develop thirteen generations in a single year, and at the end of the twelfth generation would have bred an army of ten sixtillions of aphides.

Forbush has worked it out, and says if this uncountable army was marshalled in line ten to the inch, it would extend as far as the great star Sirius, which is so far away that if a man could travel at the rate of light, which is 186,000 miles per second, the journey from earth would take him eight years.

Kirtland, too, has carefully worked out the rate of breeding of the gypsy moth, and states that if a pair of these moths and their progeny were allowed to breed unchecked for eight years, they would strip the entire United States of America of vegetation.

A Colorado beetle or potato bug would, if unchecked, multiply in one season to the number of $60,000,000$. It can thus be realised by even the dullest intellect, that at this rate of multiplication the Colorado beetle would very quickly exterminate the 


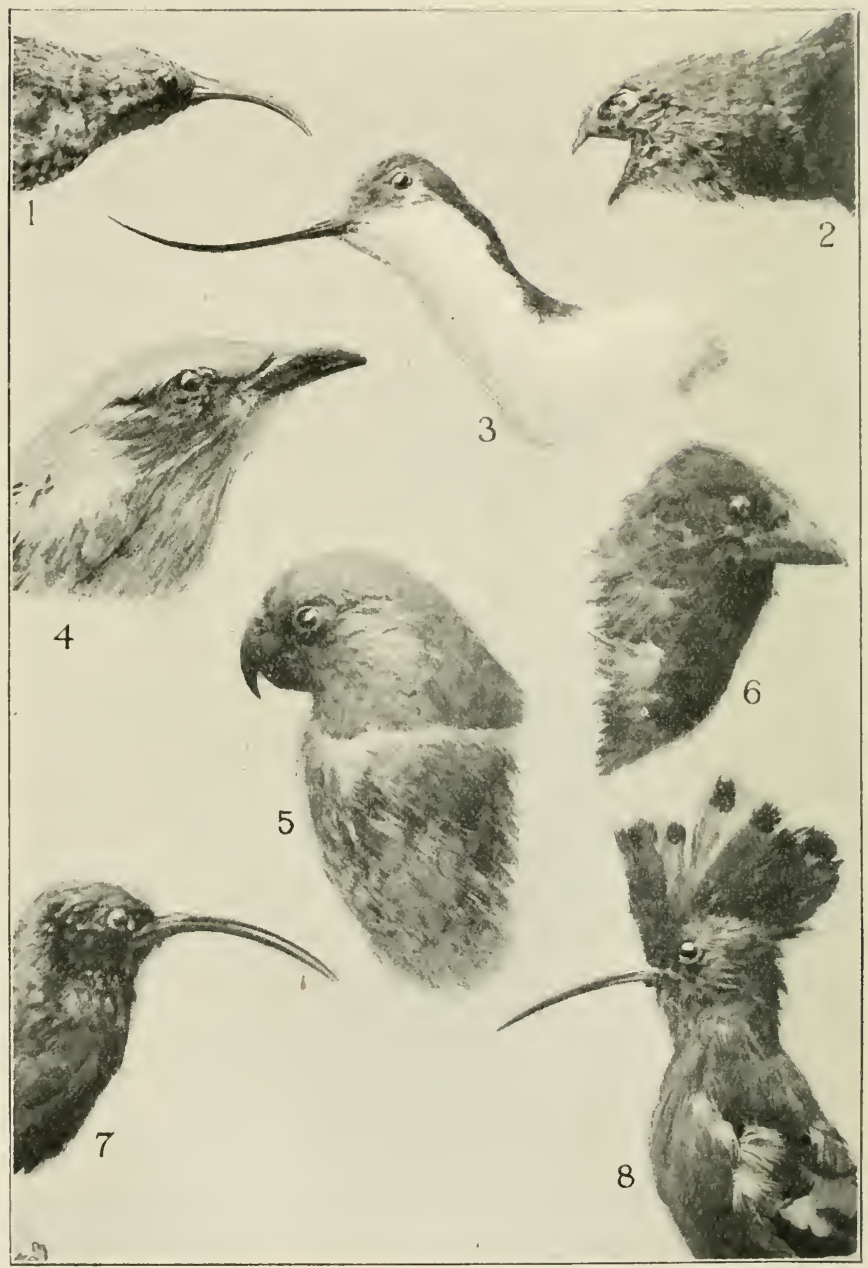

BEAKS AND THEIR USES. 


\section{BEAKS AND THEIR USES.}

1. The Black Sunbird (Cinnyris amethystinus) has a beak suited for sipping nectar from flowers.

2. With his wide-gaped jaws the Swift (Cypselus apus) captures insects in the air.

3. With a sweeping side movement, the Whimbrel (Numencius phaopus) sifts the mud of lagoons for aquatic forms of life on which it lives.

4. The European Roller (Coracias garrulus) is provided with a specially strong weapon for killing grasshoppers and bectles.

5. Meyer's Parrot (Pcocephalus Meyeri) possesses a tool for digging nest holes in trees, for breaking up hard fruits, and cracking nuts and berries.

6. The Black-Collared Barbet (Lybius torquatus) uses his beak for nipping the berries and wild fruits from forest trees.

7. The Kakelaar (Irrisor viridis) uses his long curved beak for searehing out insects in the bark and substance of forest trees.

8. The Hoopoe (Upupa africana) wins his living by prodding the ground for insects and their larve which lurk underground. 
potato plant. The migratory locust, for instance, if allowed to lay its eggs and breed unchecked, would in a few years make farming an impossibility. Aye ! it would sweep the entire country of vegetation and convert it into a barren, useless desert.

The tick is another insect scourge; it is parasitic, and feeds on the blood of animals. It reduces the condition of stock animals more or less seriously, and is an active agent in carrying disease germs from one animal to another.

The female tick lays from 2,000 to I 8,000 eggs, according to the species.

If all our tick-eating birds were destroyed and dipping suspended, these terrible pests would kill off every stock animal in the country. On taking up my residence in a house at Port Elizabeth, surrounded by large grounds and gardens, I was amazed to find the place a paradise of insect life. The flowers and vegetables which I planted were completely eaten off before reaching maturity. Prior to my tenancy, the house was uninhabited for two years, and boys had been in the habit of roaming at will about the premises with catapults and air-guns, murdering any and every bird they could find. Others searched the bushes for nests, intent on robbing them of their contents. The place became a sanctuary for birds on my advent, and within a year the insect army of occupation was annihilated.

Insects not only breed with astounding and disconcerting rapidity, but their powers of eating are, if anything, still more amazing. A caterpillar will 


\section{BIRDS}

eat three times its own weight of vegetation every day. This, on first thoughts, does not seem so very astonishing, but if applied, for instance, to a horse, it would mean the animal would require at least a ton of food every twenty-four hours to satisfy its hunger and provide for its growth. A man weighing I 50 lbs., eating only twice his own weight of food, would need a daily ration of $300 \mathrm{lbs}$.

The appetite of the vegetation-eating caterpillar is, however, dwarfed into comparative nothingness by the colossal eating powers of some of the carnivorous larvæ. One of them, for instance, will devour 200 times its original weight in twenty-four hours.

If a large caterpillar eats

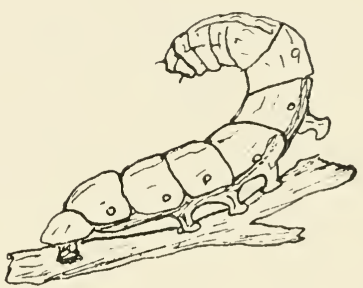

The Caterpillar takes a heavy toll of the farmers' crops. an ounce of vegetation a day, it can well be imagined the number of tons. of produce the offspring of a few moths or butterflies would devour in a season if every egg was allowed to hatch and the caterpillar permitted to live its allotted span of life. The actual bulk of vegetation devoured is not the only mischief wrought by insects. Hosts of species of insects pass the first or larval stage of their lives underground, and feed on roots, and consequently destroy the life of the young plant.

Man with all his weapons of defence could not withstand the onslaught of the insect hosts a single year without the aid of the allies which he ignorantly 


\section{NATURAL HISTORY OF SOUTH AFRICA}

persecutes, and in the front rank of which are the birds. Yet, strange to say, Man, who claims by reason of his mental superiority to be the Lord of the earth, is either directly or indirectly destroying the creatures which the all-wise Creator has provided to help him in his struggle for food and life against the most formidable of his enemies-the insects and their near relations, which, although not true insects in a scientific sense, are popularly grouped as such.

"What! would you rather see the incessant stir

Of insects in the windrows of the hay, And hear the locust and the grasshopper

Their melancholy hurdy-gurdies play?

Is this more pleasant to you than the whirr

Of meadow lark and her sweet roundelay,

Or twitter of little field-fares, as you take

Your nooning in the shade of bush and brake?"

LONGFELLOW.

Man, who claims to be guided by an educated intellect, deliberately attacks his allies instead of acting in co-operation with and safeguarding them in every way in his power. Lack of the right kind of knowledge is undoubtedly the tap root of the evil. Boys and girls leave school knowing little or nothing at all about the Natural History of the country in which they dwell. A few pick up some knowledge of the ways and habits of the lower forms of life, but the vast majority go forth to persecute and slay the creatures which are striving to make the lot of man a brighter and happier one. Nay, more! they are making it 


\section{BIRDS}

impossible for him to live and enjoy the fruits of his toil. In his orchard and garden man can, to a limited extent, keep the insects in check with various insecticides, which are after all unnatural and expensive, and often dangerous. Even with these aids he is frequently overwhelmed. When his crops, his pasturage, and his forests are invaded by ravening hordes of insects, his offensive collapses and his defences are demolished. He sits in his home, chafes, blames Providence, the Government, or thinks the visitation a Divine punishment for his sins. In this latter

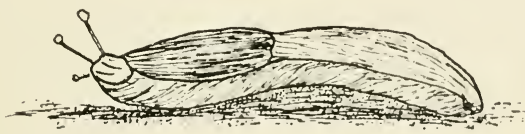

The Slug is a garden pest, and birds are its enemies.

surmise he is not far wrong, for it truly is a chastisement for his sins and those of his neighbours in allowing his friends and allies-the native birds-to be persecuted, done to death, or driven to seek less dangerous hunting grounds.

Insects are attacked by parasites, diseases, and fungi, and some kinds prey upon others; but all these natural checks, with the fight put up by man, are altogether and entirely inadequate to prevent insects from increasing to uncountable hosts and sweeping all vegetable life from the face of the earth, except by the aid of his allies the birds.

Insects are preyed upon by some species of small mammals; by lizards, toads, and other reptiles and 
batrachians; but their arch-enemy-the foe which keeps them in check-is our feathered ally, the bird. Destroy the birds, and all the other foes of insects could not prevent them from carrying all before them by sheer force of numbers.

Why are birds indispensable allies in our desperate efforts to stem the advance of the insect Hun? Because the food of the vast majority consists of insects. The seed-eating species, with but few exceptions, feed their young solely on an insect diet.

Is it then a matter for wonder that outraged Nature scourges us so severely? We deserve it, surely. There are sins of omission and commission; both are equally far-reaching in their results.

We are hypnotised by the belief that it is necessary to have our children's minds filled with what might be termed "the ballast of the ages." There is often no time left in the child's life, or no desire on the part of the parents, to have it taught those things which are necessary to enable it to develop into a useful and progressive citizen of the State, and to pilot its way through life with the minimum of mishaps and disasters. To study Nature is to study the works of God. It is eminently practical in every sense of the word, and is also a powerful factor in the awakening of the moral and spiritual nature of man.

Why have so many of the human race degenerated into mere money-making machines, with intervals of leisure for the gratification of their animal passions and desires? Chiefly because their minds have never been awakened to a realisation of the fairy- 


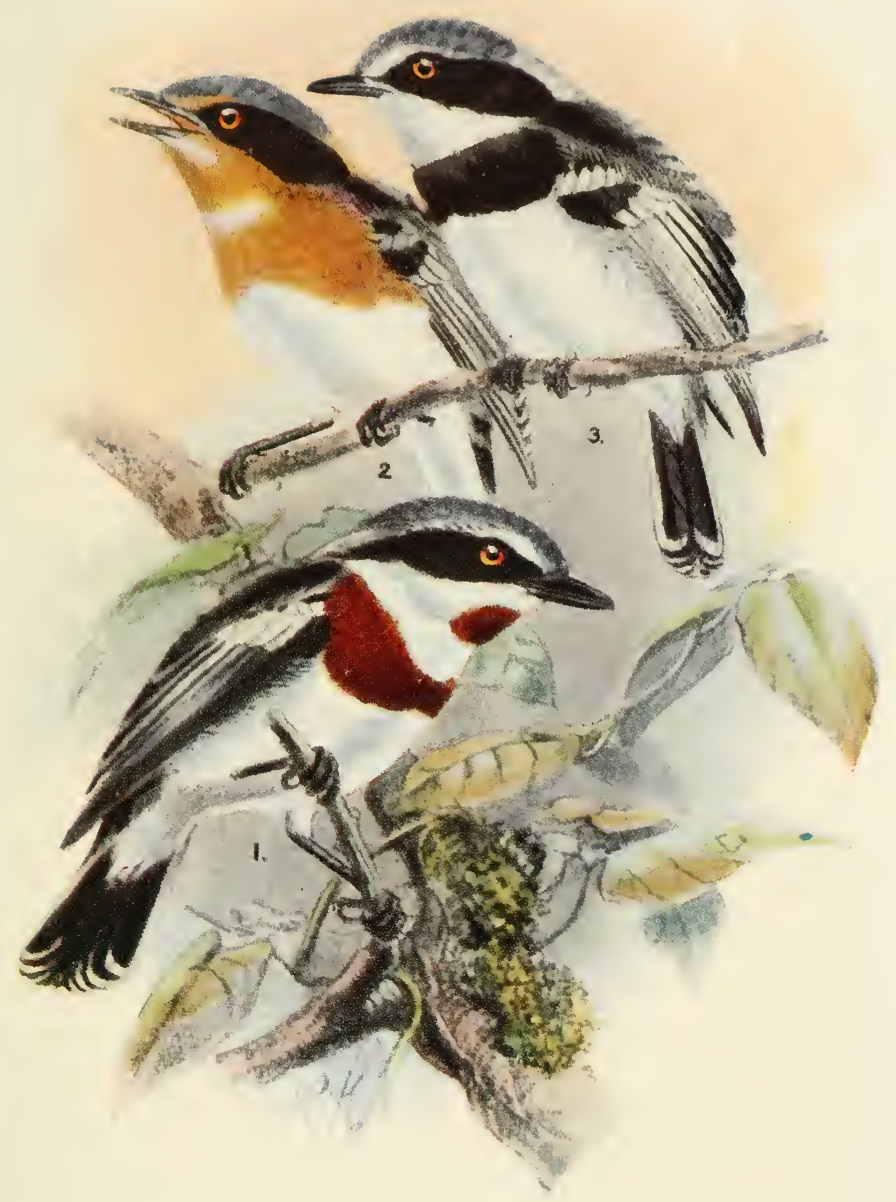

PLATE II.-(1) White-flanked Flycatcher (Pachyprora molitor)

(2) Pririt Flycatcher (Pachyprora pririt).

The mission of the Flycatcher is to capture insects in the aut 



\section{BIRDS}

land around them opened up by a study of Natural History.

What is sport to man is often death or persecution to some creature which, more likely than not, is a valuable ally, but he knows it not. Since the invention of the gun, man has been engaged upon the deliberate and wanton upsetting of the balance of Nature. He ventures where angels fear to tread, not because of his bravery, but by reason of his want of knowledge. Knowing no better, he allows his children to wantonly maim and kill the wild birds, and rob their nests. He hands down to them erroneous, mischievous, and harmful beliefs in regard to the sub-human inhabitants of veld, mountain, forest, and stream, which results in the persecution of the creatures which are helping him in his battle for life.

For instance, it is popularly believed the harmless little geko lizard is venomous. The result is, this highly useful little insect-eater is killed at sight. So much for the wisdom of man. Conversing with a lady school teacher from an up-country dorp, I expressed regret at the profound ignorance of our children on the ways and habits of the wild creatures of this country. She admitted the fact, but was eager to inform me she encouraged the boys in the school to learn Natural History. One boy, she declared, had made a wonderful collection of birds' skulls. "How did he procure the skulls?" I queried. "He went out excursions and killed the birds with a shotgun," she replied. "Other boys," she declared with pride, “ collected birds' eggs, and had really lovely 


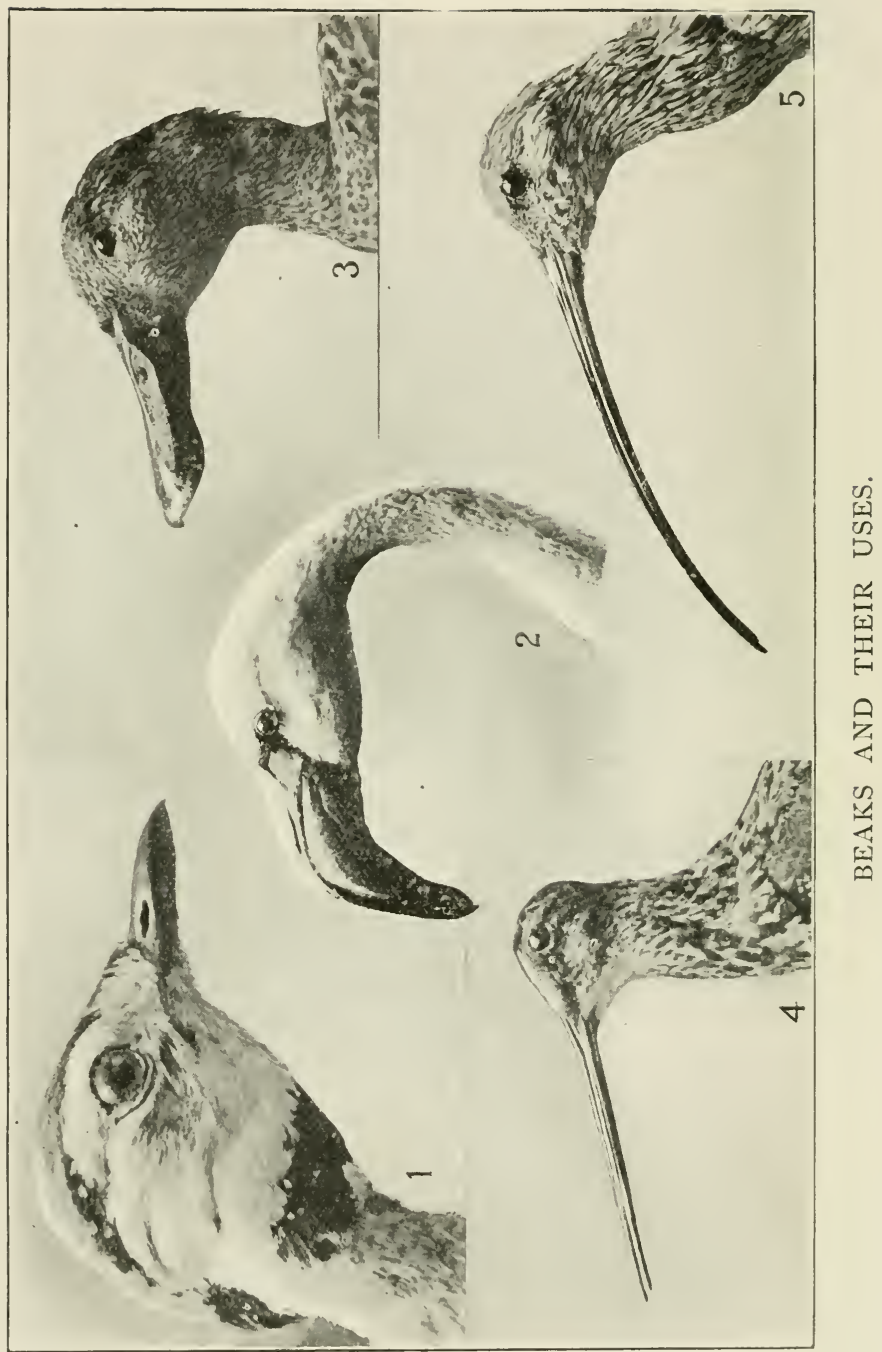


BEAKS ANI) THEIR USES.

1. The Natal Knorhaan (Otis larrowii) digs among the roots of grasses and shrubs on the veld for insects and their larva.

2. The Flaningo (Phonicopterus roseus) has a bill wonderfully adapted for digging and sifting the slime and mud of lagoons for crustacea and mollusca.

3. The Cape Shoveller Duck (Spatula capensis) shovels and sifts the mud and aquatic vegetation for snails, which are the hosts of the liver fluke in sheep and Bilharzia in man.

4. The Ethiopian Snipe (Gallinago nigripennis) bores into the soft mud of marshes for worms and aquatic insects.

5. The Curlew (Numenius arquatus) probes in the mud for its food, which consists of the various small creatures which live therein. 


\section{NATURAL HISTORY OF SOUTH AFRICA}

collections." "I suppose they took the entire clutch of eggs every time?" I asked. "Yes! oh, yes! They were so eager, you know, and so jealous lest their rivals should get more eggs than they.'

In South Africa there are about 920 species and subspecies of birds. Of this great host not more than twenty species can be said to be harmful to man without sufficient redeeming qualities, from an economic point of view, to justify their preservation. There are some which, when judged from a

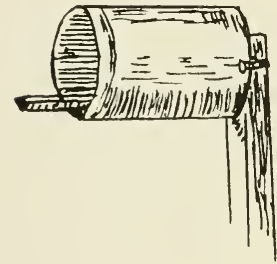

Convert all your old tin cans into bird-nesting boxes. broad standpoint, are beneficial to man as a whole, but which are a pest to individuals such as fruit growers, stock farmers, and graingrowing farmers.

The colies or muis vogels and the bulbuls, for instance, are foes to the fruit farmers; the larger birds of prey can expect no mercy from stock and poultry farmers; and the "vinks" are a pest to the grain grower.

However, each family of birds will be subsequently dealt with from an economic point of view, so that we may be fully acquainted with the various services rendered us by them, and the amount of payment some of them take from us for services rendered. It will then rest with us to judge whether any of them are taking too heavy a wage in fruit, corn, bees, poultry, or young stock for the work they perform.

One thing is beyond dispute and must be conceded by every reasoning individual, viz., that to kill or other- 


\section{BIRDS}

wise persecute the birds which are helping us all the time in our fight against the voracious hordes of insects, is a deliberate crime to posterity and a grave moral wrong.

Is a man morally justified in persecuting, maiming, or killing useful birds because no man-made law is violated? If we saw a big, strong man persecuting or killing a helpless child we should be aflame with anger or righteous indignation. On the contrary, when we see a man deliberately shoot a helpless little bird friend, we pass by and heed not. The life of a useful insectivorous bird is, or should be, as sacred as the life of a child.

It is deplorable, but nevertheless true, that a large percentage of people are kept in the path of righteousness solely by fear of consequences; hence the necessity for good and sound legislation and machinery for the enforcement of the laws, until such time as the race, as a whole, have advanced to a higher moral and spiritual plane. Before interfering with the marvellous and beautiful scheme of Nature, it behoves man to make careful study and not allow himself to be guided and dominated by his passions, inclinations, and prejudices. After carefully weighing the evidence, should it be found that any bird, animal, or reptile is, by its actions, hampering the advancement of the human race, then, and not till then, are we morally justified in removing it from the world of the living. When any creature is destroyed which acts as a check on another, the inevitable result is a multiplication of the latter. The destruction of a pair of breeding starlings, 


\section{NATURAL HISTORY OF SOUTH AFRICA}

for instance, which involves the death of four to six nestling birds, means the increase of a minimum of 30,000 caterpillars and grubs within six weeks. These caterpillars soon reach the adult condition, change into chrysalides, and emerge as moths, butterflies, and beetles. Each of the females lays thousands of eggs, which bring forth a vast and destructive army of larvæ, and from the 30,000 caterpillars and grubs there will arise within a few short months an uncountable host. All because of the thoughtless or wanton destruction of a pair of breeding insectivorous birds.

Many years ago the English press gave colour to the erroneous and stupid belief that owls were birds of evil omen, and that they were destroyers of chickens and useful birds. Some of the farmers, believing these false statements, mercilessly persecuted the owls, and the survivors retreated to the wilds. The following season loud and bitter were the complaints about the damage done to the crops and young poultry by rats and mice. The second season proved still worse, and many a farmer was ruined.

There has been much controversy as to whether the English sparrow (Passer domesticus) does more harm than good. The chief indictment is that it eats the buds of fruit trees, with a consequent serious diminution of the subsequent crop. There is no doubt at all when this species of bird increases abnormally in numbers it does become a pest, as is the case with some of the South African seed-eating birds, whose ranks have to be thinned when their attacks assume formidable 


\section{BIRDS}

proportions. 'The thinning process, however, should only be embarked upon when it is absolutely certain the birds are doing more harm than good, for it must be remembered abnormal eruptions of insects cause the birds to concentrate. The chief concern of birds during the spring and early summer is to find the most favourable localities for rearing their families. The young are fed on an insect diet and, unless insects are abundant, the young birds, or a large proportion of them, will perish.

Some years ago the farmers in Hungary, incensed by the damage done by sparrows to budding fruit trees, and actuated largely by superstition, prejudice, and ignorance, made war on this species of bird and nearly exterminated it. Within the short period of five years the land was in the grip of the insect Huns. The farmers became panic-stricken, for utter ruination stared them in the face. Fortunately knowledge, and with it repentance in this instance, did not come too late. The sparrow came into his own again, and the country was saved.

James Buckland, whose life's work has been devoted to spreading knowledge in regard to the economic value of birds, relates several instances of the serious consequences attendant on the indiscriminate destruction of wild birds, which are briefly as follows:-

In the island of Bourbon the people, impelled by erroneous beliefs and superstition, set a price on the martin's head. The birds were nearly annihilated, and, as a consequence, grasshoppers overspread the VOL. I. 


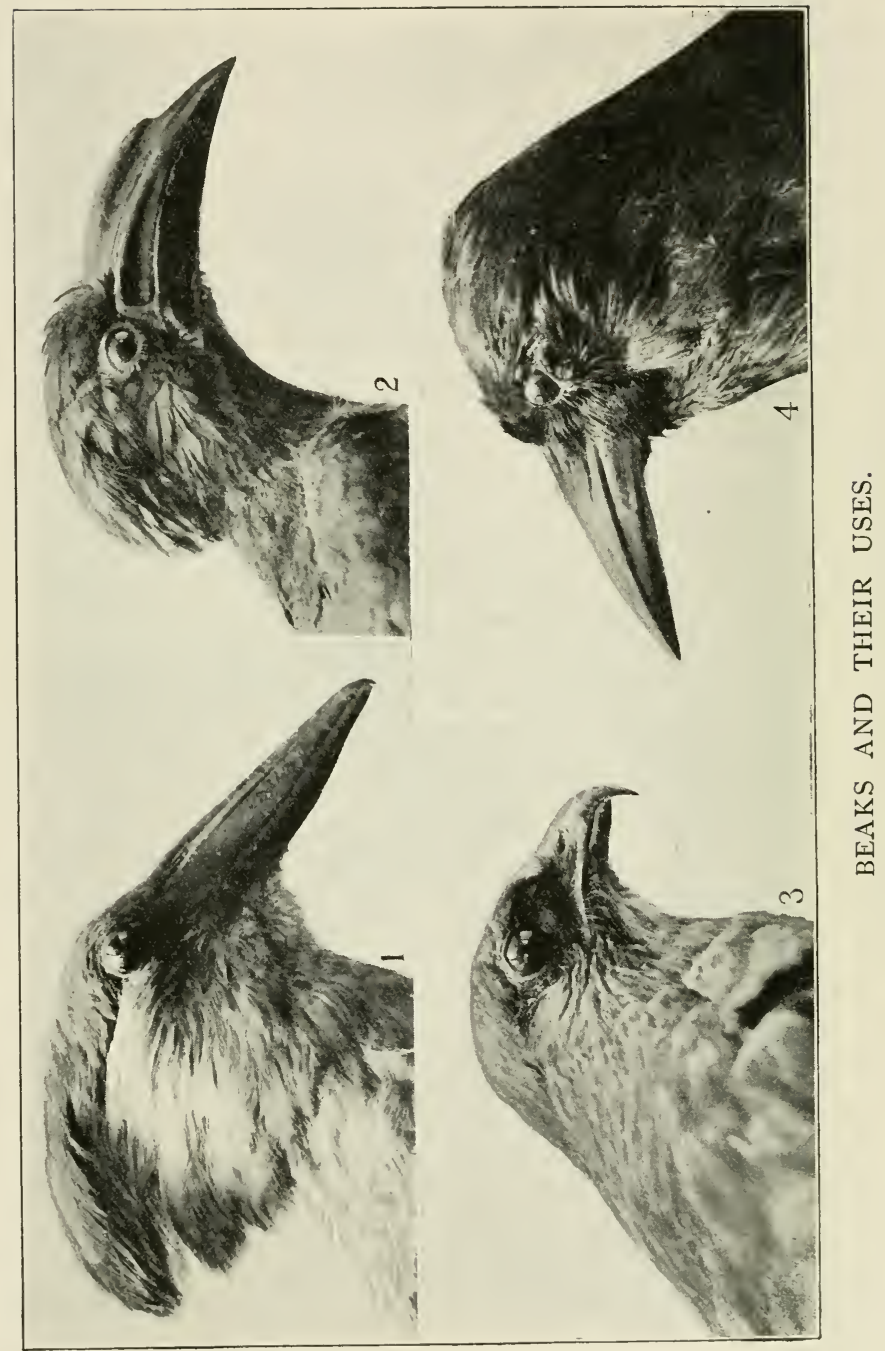




\section{BEAKS AND THEIR USES.}

1. Nature provides the Hammerkop (Scopus umbretta) with an efficient tool for snapping up frogs and other aquatic creatures.

2. The Crowned Hornbill (Lophoceros melanoleucus) uses the only tool Nature gives him to pick fruit and berries, and to plaster up the entrance hole of his nest.

3. The Jackal Buzzard (Buteo jackal) slays and rends rats, snakes, birds, and small mammals with his powerful curved beak.

4. With its hard pick-like bill the Black Crow (Cornus capensis) digs up the soil for root-eating grubs. 


\section{NATURAL HISTORY OF SOUTH AFRICA}

island and the people were frantic with fear lest they should perish. It was indeed fortunate for those foolish people the martin was not quite beyond recall. Every encouragement was given these birds, and swift fell the punishment on anyone who persecuted them. The martins, finding an abundant food supply, increased rapidly in numbers, and the devastating hordes of grasshoppers were destroyed.

In the year $\mathrm{I} 86 \mathrm{I}$ the harvests of France were very poor, and the Minister for Agriculture appointed a Commission to investigate the cause of this alarming diminution in the crops throughout the country. The Commission attributed the unusually poor return to the ravages of insects. It seems the birds which had been keeping the insects in check had been shot, snared, and trapped in such numbers that the survivors were unable to maintain the balance of Nature, and the insects multiplied and overspread the land to scourge man for his ignorance and folly.

This Commission reported that they could suggest no other remedy against the ravages of insects than prompt and energetic legislation to prevent the destruction of birds.

For some years prior to 1877 the farmers of Nebraska were in the habit of poisoning the blackbirds during the spring and autumn around the cornfields, because they believed this bird was damaging the crops, particularly the wheat. Large numbers of prairie chicken, quail, plover, and various other species of eminently useful birds were destroyed at the same time by eating the poisoned grain. Again 
outraged Nature arose and smote those unreasoning farmers in the form of countless hosts of locusts which swept the land bare of crops and pasturage. "As ye sow, so shall ye reap."

In 1895 , in the region of Ekaterinburg, in Russian Siberia, two species of cut-worms and about ten species of locusts devastated the countryside, and the farmers were in despair, for there was famine throughout the land. The local Society of Natural Sciences carefully investigated the cause, and declared it to be due to the almost complete destruction of the native birds, which had been killed and their plumage sent abroad to gratify women's vanity.

The tick is a living, ever-present nightmare to the farmer. Knowing its disease-carrying propensities, he never can tell when it may infect his flocks and herds with a disease that will destroy, perchance, the majority of them. The tick is the most formidable enemy with which the stock farmer has to contend.

With but few exceptions the ground birds feed more or less on ticks. Some species of birds, such as the tick birds (Buphaga), take them direct from the cattle, but the majority feed on them upon the herbage and ground. When a female tick has gorged herself with blood, she drops from her host and crawls away to seek a suitable place in which to deposit her eggs. These blood-gorged ticks are eagerly sought after by birds, which frequent the grazing grounds of cattle to seek for them.

Every female tick so destroyed means the destruction of thousands of eggs. For instance a quail, 
partridge, guinea-fowl, lark, rail, starling, or any one of the many tick-devouring birds, in a single season is capable of killing vast swarms of ticks directly and indirectly.

I have found as many as fifty gorged female ticks in the crop of a single cattle egret (Bubulcus ibis). Taking the minimum number of eggs laid by one of these ticks at 2,000, we have the tremendous total of I००,०००. In the crop of a quail, eight of these mature female ticks were found. This, multiplied by 2,000 , makes a total of I 6,000 ticks accounted for by one bird in a day ; or, during the course of the spring and summer, the colossal number of 3,000,000 ticks would have been accounted for by one quail.

Twelve crowned lapwings (Stephanibyx coronatus) or kiewitjes, as they are popularly termed, were shot during December on a cattle-frequented veld. Nine of these contained an average of five blue female ticks distended with blood or eggs. Again, taking the minimum number of eggs laid by each tick at 2,000, we have a total of I0,000 ticks accounted for by each bird in one day. In three months these birds, eating female ticks at the rate of five per day, would account for $\mathrm{I}, 000,000$. If these had survived, and taking half their number to be females, the following season they would have totalled something like $6,000,000,000$.

Yet we find otherwise reasonable, intelligent, humane, and unselfish men deliberately slaying these tick-destroying birds for sport, and for the pot, or to obtain a few paltry pence for their plumage. We also 


\section{BIRDS}

find otherwise kind, loving, gentle, and affectionate women deliberately encouraging the cold-blooded murder of these valuable allies of our race by adorning their headgear with their plumage.

Any woman wearing this badge of cruelty should be regarded as a pariah, and shunned by all humane people.

The appalling destruction of insect-eating birds in Jamaica, chiefly to supply the demands of the millinery trade, resulted in such a plague of grass ticks, flies, and mosquitoes, that all breeds of cattle, with the exception of Indian cattle, were exterminated, and the death-rate amongst other domestic animals and the human population was considerably raised.

In French West Africa the unrestricted shooting and trapping of the guinea-fowl resulted in epidemics of germ diseases amongst the native tribes, and the destruction of crops by beetles, cut-worms, grubs, and locusts.

The wholesale destruction of native birds is followed by disaster to man as surely as day follows night. Man idly, wilfully, or ignorantly brings about the cause, and he suffers the effect to the full. To-day he has men of science who are capable of guiding and teaching him how to avoid most of the set-backs he gets in his journey through life, but he heeds them not. When they cry aloud in protest at his deeds of vandalism, he turns a deaf ear ; or when they essay to spread the seed of knowledge in writings, or by means of lectures, those whom they seek to benefit actually put 


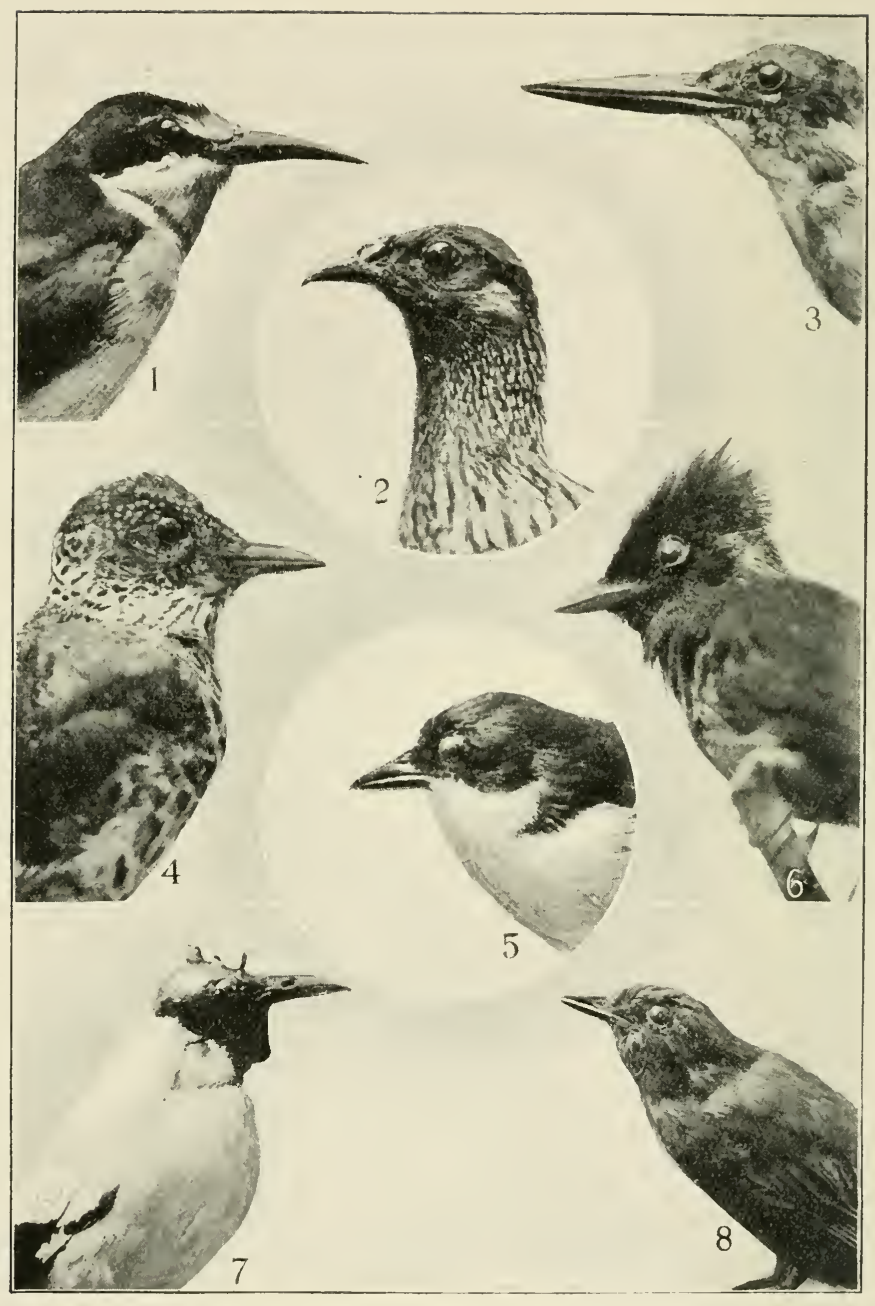

BEAKS AND THEIR USES. 


\section{BEAKS AND THEIR USES.}

1. The European Bee-Eater (Mcrops apiaster) has an instrument perfectly adapted for catching bees on the wing and crushing them to death without running any risks.

2. The Noisy Frankolin or Bush Pheasant (Frankolinus capensis) grubs in the loose loam of the bushlands for insects which pass the larval phase of their lives there.

3. The Half-Collared Kingfisher (Alcedo scmitorquatus) gets his living by diving for fishes.

4. The Cardinal Woodpecker (Dendropicus cardinalis) pecks out the decaycd wood of trees in search of the larve of wood-boring beetles, and to make nest holes in which his family are reared.

5. The Greater Puff Back Shrike (Dryoscopus fermgincus) crushes beetles with his short strong beak.

6. The Paradise Flycatcher (Tcrpsiphone perspicillata) snaps up insects on the wing and crushes them to death.

7. The Wattled Starling or Locust Bird (Dilophus carunculatus) captures locusts in the air and, with a snap, he shears off the victim's wings and legs.

8. The Noisy Robin Chat or Piet-myn-vrouw (Cossyfra bicolor) slays the insects which lurk in the trees and issue forth before sunrise and after sundown. 
obstacles in their way. When the Mormons first settled in Utah, hordes of black crickets swarmed down from the mountains and swept off their crops to the last seedling. What were vast fields of wheat in the morning were as bare as freshly-harrowed land in the evening. The first year's crop was a total failure. The second year's crop promised to yield a huge harvest, for the weather conditions were ideal, but the cricket host again swarmed down and laid the land bare, leaving not a blade of wheat. The Mormons became panic-stricken, for they were on the brink of starvation. Suddenly, as though sent from heaven, hundreds of thousands of Franklin's gull appeared and devoured the crickets, thus saving the settlers from extinction.

Finding ample food for its needs, this species of gull has been a regular visitor to Utah, and continues to keep the crickets in check. It is, consequently, held sacred by the inhabitants, who have erected a monument to it in Salt Lake City, so that posterity may know these gulls were, and are, keeping the insect hosts in check, and thus preserving the State from the financial ruin which would otherwise overtake it.

Every country has its hosts of vegetation-devouring insects, and these are kept in check by the native birds. Occasionally they gain the upper hand in one or more localities, but the birds soon discover the fact, and flock to the threatened area and quickly reduce the ranks of the invading host. Should the birds increase unduly in numbers, there is a dearth of insect food, resulting in the migration or dying off of considerable numbers of birds. This decrease in birds again gives 


\section{BIRDS}

the insects a chance to increase, and so the pendulum of Nature swings to and fro until man spreads over the land and begins tilling the soil. Finding certain species of birds are taking some slight payment in grain or fruit for their immensely valuable services, he foolishly begins a war of extermination upon birds generally. Apart from any damage the birds may do, it is a practice common in all newly-developed countries for colonists to destroy the native birds for the pot, and often for no other reason than to gratify the brutal desire to kill, which is inherited from our remote barbarian cave-dwelling ancestors. Nay! we do our primitive ancestors a grievous wrong in making this comparison.

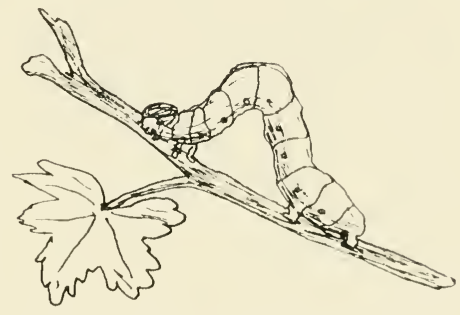

The Caterpillar defoliates wur shrubs and trees. The bird is its enemy.

They hunted and killed animals and birds for food and raiment, impelled by dire necessity. We, on the contrary, kill for the mere lust of killing.

When a boy or youth acquires a gun, he invariably sallies forth seeking " something to kill." He knows no better, for his parents and teachers have not taught him that animals and birds are warm-blooded creatures with nervous systems as sensitive to pain as ours, and that they love, mate, rear families, and live lives of greater wisdom and usefulness than many of the men who foolishly believe they have the moral right to persecute and murder them at will. 
This thoughtless and foolhardy practice of killing the native birds brings retribution sharp and severe upon the pioneer. The swarms of insects, finding the produce of the cultivated fields more succulent fare than the native vegetation to which they were accustomed, abandon the latter and invade the former. The new diet being so abundant and nourishing, they multiply with alarming rapidity. Their rapid increase is powerfully favoured, and indeed made easy, owing to the farmer, his sons, and employees having persecuted the birds so relentlessly that the survivors had fled in terror to the wilds.

A servant is surely worthy his hire. Apparently this is not so with our good and useful helpers-the birds. Those which are purely insectivorous and take no payment at all are killed, trapped, and their homes robbed of eggs and young. The species which take a little payment in the shape of corn or fruit for their heavy labours on behalf of man, are hated and hunted relentlessly. Man is, and always has been, apt to observe superficially and arrive at erroneous conclusions.

"You call them thieves and pillagers; but know

They are the winged wardens of your farms, Who from the corn-fields drive the insidious foe,

And from your harvests keep a hundred harms.

Even the blackest of them all- the crow-

Renders good service as your man-at-arms,

Crushing the beetle in his coat of mail, And crying havoc on the slug and snail."

LONGFELLOW. 


\section{BIRDS}

The history of man and his attitude to wild birds in every country in which he has migrated with his fire-arms is an example. We have a convincing instance, in the records of the pioneer farmers of New Zealand, of the terrible damage which a single species of caterpillar inflicted upon them. When they began to cultivate the virgin soil on an extensive scale they, as is usual with their kind, killed and allowed their boys to amuse themselves by killing and terrorising the native birds.

A caterpillar which had hitherto struggled hard for a living on native vegetation, and had been attacked constantly by hungry, watchful birds, began to invade the cultivated fields from which the birds had been driven. To the consternation of the farmers, it multiplied as if by magic. It swarmed in uncountable hosts and spread over the land. Beautiful green fields of wheat, miles in extent, became brown with the hue of this destructive little creature. Nothing could stop its advance. It became a blasting army. Thousands of cattle and sheep were driven to and fro over them, to no purpose. Horse rollers, steam rollers, and fire were employed as weapons. Deep trenches of great extent were dug and covered over when full of caterpillars. All human efforts were unavailing. No apparent impression was made on this mighty insect host. Railway trains were held up. The engineers could not plough their way through the overwhelming hordes of caterpillars. Man was hopelessly defeatedand by a caterpillar.

It became apparent that the colonisation of the 


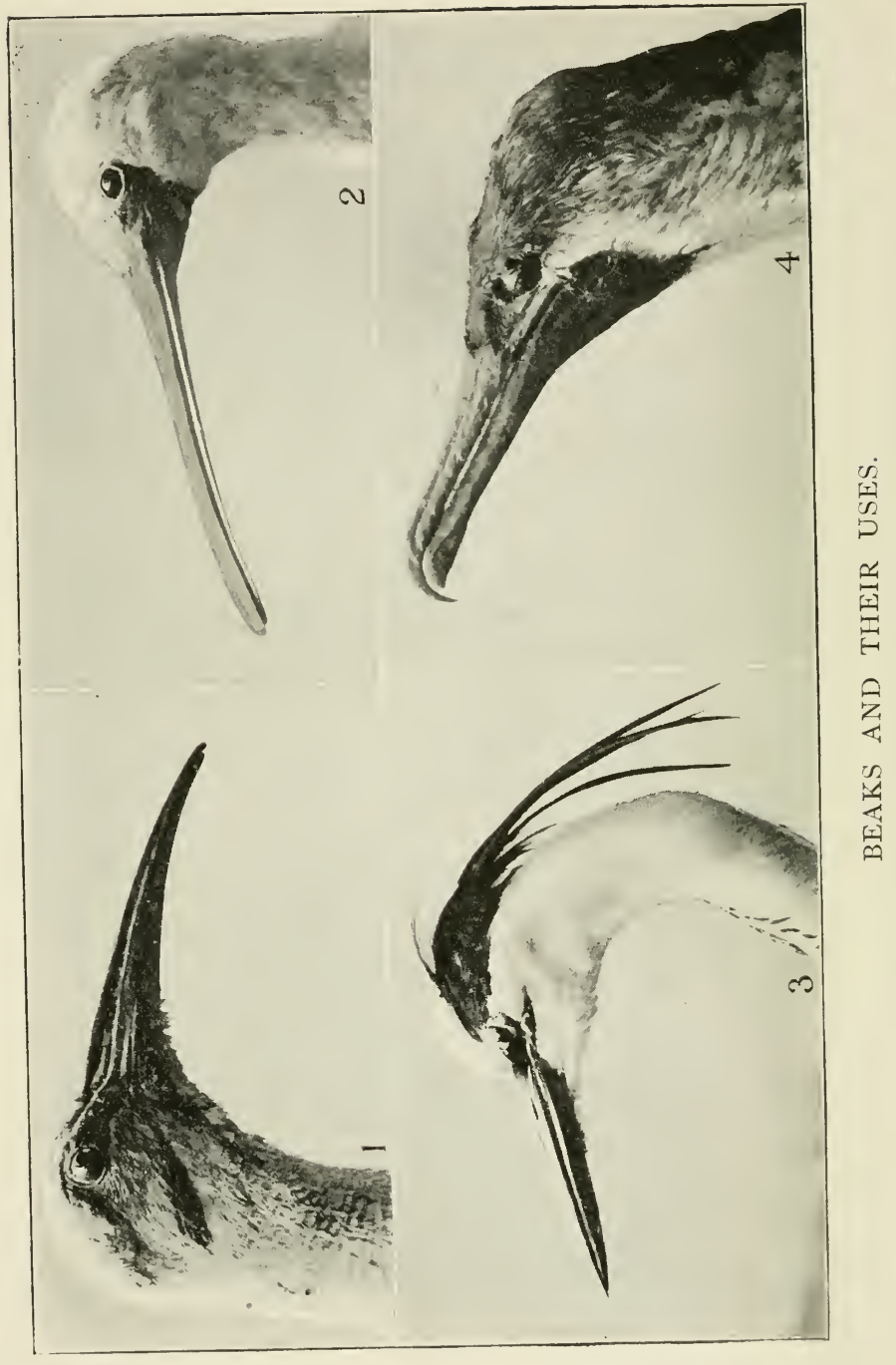




\section{BEAKS AND THEIR USES.}

1. The Hadada Ibis (Hagedashia hagedash) uses its beak like we do a pick to unearth insects and their larvæ on which it feeds.

2. The African Spoonbill (Platalea alba) uses its flat, spoon-like beak to explore for shellfish, crabs, and worms in the mud, and also for snapping up small fishes and aquatic insects.

3. The Grey Heron (Ardea cinerea) stands immovable in the water and impales the fish and frogs which come within striking distance.

4. The Cormorant (Phalacrocorax lucidus) pursues fishes under water in the ocean and tidal rivers, and kills them with the sharp point of his powerful beak. 
country could not be proceeded with. All man's efforts to check the conquering host proved as effective as a child's bank of sand erected on the seashore to stem the incoming tide. The one and only hope of salvation lay with the native birds. The chastened farmers, repenting of their folly, did their utmost to encourage the birds to return.

The birds had, however, suffered so severely from his treachery and his murderous weapons that those which ventured on his fields fled in terror at sight of him. Until the advent of the European, the birds had lived in loving friendship with the Maoris. They now refused to be propitiated. Their experiences had made them excessively suspicious of all human-folk. As a last resource, and as a final despairing experiment, the Government introduced birds from England. The one which made itself thoroughly at home and bred most rapidly was the common house sparrow (Passer domesticus). To the help rendered by this much-despised and persecuted bird the New Zealand farmers owed their salvation. Indeed, the entire population was rescued from destitution and red ruin, for those resident in the villages and towns were dependent upon the farming community directly and indirectly for a living.

The great majority of reptiles are useful allies in our war against insects, but most of them cease to feed, and hibernate during the winter months; and even when they are abroad their needs are not large in the way of food, very little satisfying them.

On the contrary, birds feed daily throughout the 


\section{BIRDS}

year. They have a high bodily temperature and lead an active life, entailing a great expenditure of muscle and nerve energy, with a considerable loss of heat, consequently their requirements in the way of food are large. Nature has provided for this in giving the bird a strong and rapid digestion, which impels it to seek food at frequent intervals. When the parent birds have a nestful of youngsters to provide for, they are on the war-path from daylight until dusk. A pair of birds with four nestlings destroy as many insects as a dozen single birds, because the rapidly-growing fledglings require an abundance of food. Birds are not only formidable foes of insects, but they help very largely in keeping weeds and other forms of undesirable vegetation in check. Also they are largely instrumental in forming forests, both by sowing tree seeds broadcast, and by protecting the growing trees against the ravages of insects.

Birds which feed largely on fruit and berries do not, as a general rule, digest the seeds; these pass through their digestive organs unchanged.

On the contrary, the true seed-eating birds, which feed chiefly on the seeds of weeds, digest the seeds completely, and thus render man very valuable services.

When these birds attack corn-lands in unusually large numbers, of course it lies with each farmer to use his judgment as to whether the harm they are doing is paid for in full or not by the weed seeds and insects they devour. It must be remembered that birds lay their eggs during the spring and early summer, conse-

VOL. I. 
quently the young are born when the crops are green, tender, and especially attractive to caterpillars and other insects which are naturally most abundant at that time. It is, in fact, the Creator's provision against abnormal outbreaks of insect life. It means that at the very time when insects are most abundant and capable of doing the maximum amount of harm in cultivated lands, their enemies the birds begin rearing their families. This means an enormously increased consumption of insects. Numbers of birds, when adult, live mainly, and sometimes entirely, on seeds, but they feed their nestlings on caterpillars and other kinds of destructive larvæ.

Therefore let no man raise his hand against any of our feathered helpers without long and careful observation and subsequent deliberation. The troubles of the New Zealand farmers were not at an end with the suppression of the insect peril. The Scotch thistle had been accidentally or intentionally introduced. It flourished exceedingly in its new environment, and bid fair to take possession of the entire country. The farmers utterly spent themselves in energy and money in their desperate struggle to overthrow this new enemy which threatened their very existence.

They cut and burnt the plants, poured turpentine on the split stumps to kill the roots, and in other ways sought to exterminate this formidable weed. Their labours were in vain. The weed had come to stay, for the climate was genial, and strongly favoured its rapid growth. The wind carried the clouds of thistledown far and wide and, wherever it fell, a plant sprang 


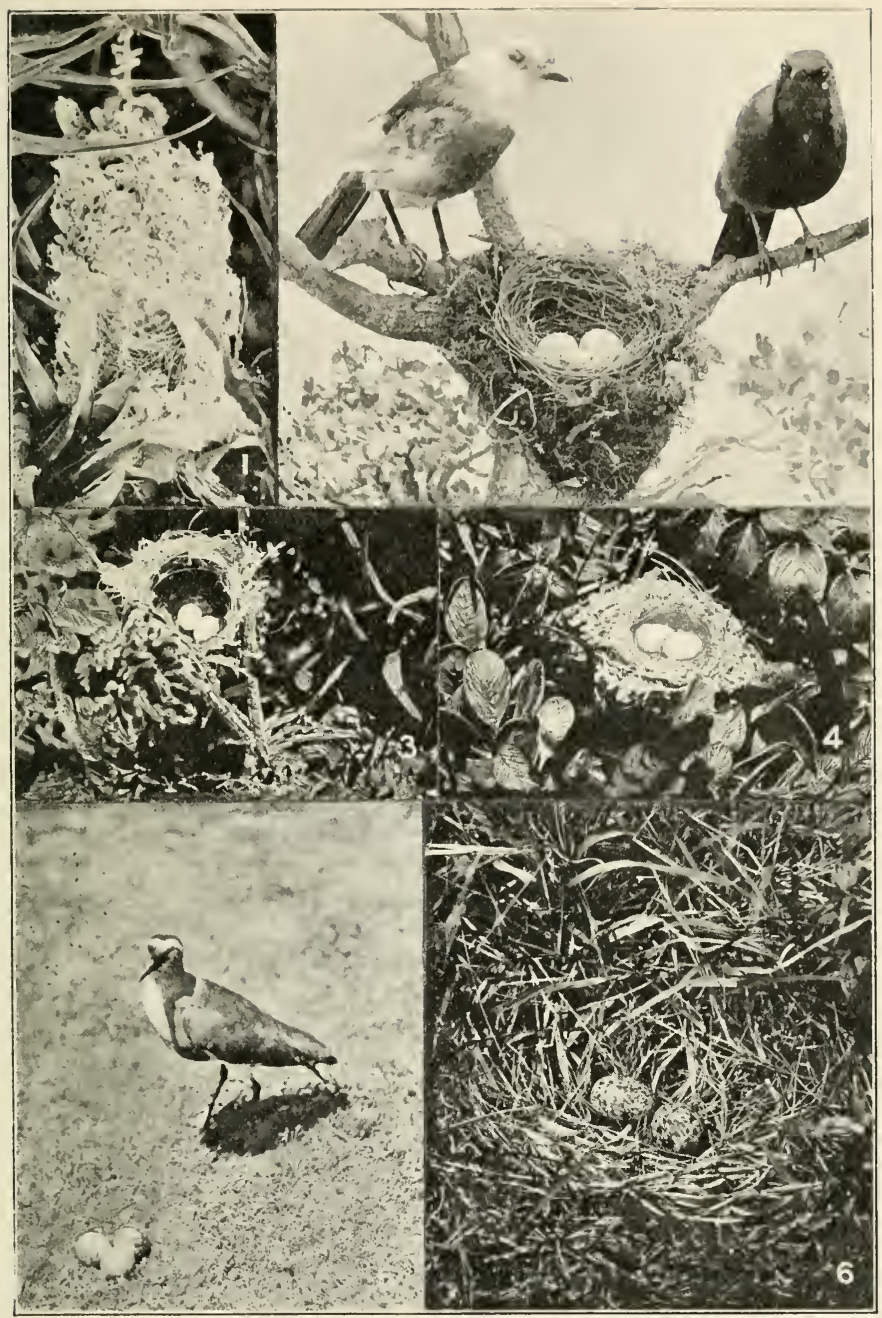

1. The Crombec Warbler makes a nest of cobwebs.

2. Bakbakiri Shrike, or Cock-a-Vick. One of the shrikes (female) in this illustration is a partial albino.

3. The Little White-eye, or Glas-oogie, builds its nest between two twigs.

4. The Large Yellow Seed-eater's nest is usually found in a shrub.

5. The Crowned Lapwing, or Kiewitje, lays its eggs on the bare ground.

6. The Thick-knee also rears her family on the ground. 
to life. The pest steadily advanced until the fields were covered with dense masses of prickly plants struggling one with another for elbow-room.

Again the sparrow, which had saved the colonists from the insect invasion, came to the rescue. These birds had multiplied and overspread the country, and it was a fortunate circumstance for the farmers that they had found the country so congenial. In tens of thousands the sparrows assembled and fed upon the seeds of the thistle. Possibly an ancestral liking for it had been revived, for they abandoned all other kinds of seeds and fed exclusively on it, and the weed was vanquished; for, aided so magnificently by their feathered allies, the farmers were able to get it under control.

Man's memory for good and kind services rendered is short. Injure him in any way, however, and his memory is long-regrettably long. Man readily forgets a kindness, but an injury rankles long and persistently in his brain cells, like a noxious parasitic growth.

Buckland tells us that the sparrow was regarded in his day in New Zealand " as an impudent thief, without any redeeming feature in its character." True, when the sparrow increases abnormally in numbers, it does considerable harm. The too rapid increase of the bird may be checked with advantage at times in and about settlements, but in the light of past experiences the New Zealanders would be indeed unwise ever to organise campaigns for its entire extermination. In the face of numerous and bitter complaints and revilings from farmers against the sparrow, there are 


\section{BIRDS}

enormous yearly harvests. In fact, New Zealand is famed throughout the world for its bountiful and unprecedented harvests of grain.

The average man reasons from effect to cause in a very superficial way. The New Zealand farmer, for instance, saw the sparrow eating his grain. The bird, therefore, stood condemned. It was stealing some of his property. His mind was aflame with the desire for revenge. He did not pause to consider why he had such a heavy crop of grain. If he did he would, perchance, have realised it was because of the absence of caterpillars and noxious weeds, and that the sparrow was largely responsible for this desirable state of things.

The farmer willingly pays his human labourers their hire, and carefully feeds and cares for his draught animals; but when the bird takes five or perhaps ten per cent. of the wages it is entitled to, the shortsighted husbandman is loud in his complaints against the "impudent thefts" of his wageless labourers. Not a grain will he willingly give to the bird that has helped him.

A typical instance came to my notice in Natal. A farmer of my acquaintance growled loud and long at the birds which ate his corn. He took me round a great field of ripening corn and pointed out the damage seed-eating birds had done. Yes, true enough the grain had been eaten along the fringes of the field. The evidence was conclusive to the farmer, so he, his sons, and servants made war on the birds; they were shot, trapped, snared, and their nests destroyed. 
He visited a neighbouring colony of weaver birds, and with a shot-gun demolished over a hundred hanging nests with their living contents. He gloried in the work of slaughter. He would exterminate these rascally, thieving birds. Those he did not kill fled in frenzied terror from the neighbourhood to safer hunting grounds. He kept up this campaign for two years. The third season I happened to visit him. "Well, how are the crops?" I asked. "Miserable; never had a poorer crop of forage, and what there is of it is mixed with weeds." The next season was worse; the crop wasn't worth harvesting, and in disgust he turned his cattle into it. I explained to him that from the time the seed was harrowed into the soil, the insects had been busy below ground and above ground devouring the germinating corn, the roots, and the tender growing plants. The surviving plants were unable to outgrow and smother the weeds, and consequently the latter grew and reached maturity, scattering their undesirable seeds over his lands.

If this farmer had confined his slaughter of the birds to reducing to normal those species which had increased abnormally, it would have been well for him.

The head gardener of Sheffield Union, after thirty-five years' experience of the economic value of birds, says:

"In the trying summer of I9I I, bird-life played a very conspicuous part in our efforts to combat the ravages of insects. The birds generally known as seed-eaters became prominent insect feeders. I can say this from very personal experience, being respon- 


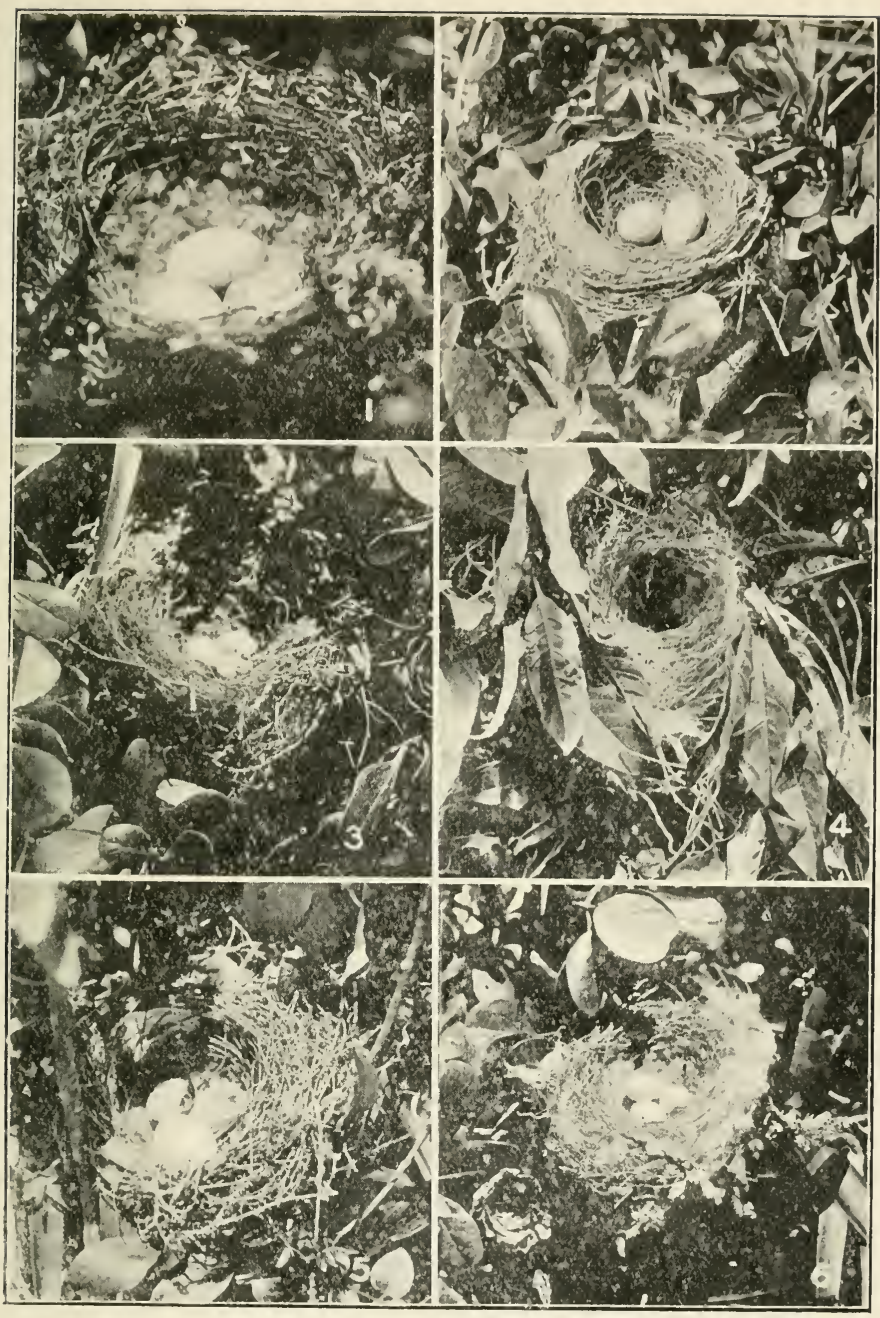

1. Nest of the Silent Bush Robin, or Fiskal Flycatcher, in a tree.

2. The nest of the Cape or Olivaceous Thrush in the fork of a tree.

3. The familiar Cape Robin Chat builds its nest in hedges and shrubs.

4. The nest of the dainty Bar-throated Warbler in a low bush.

5. Cape Bulbul, with egg of Cuckoo.

6. The neat and cosy nest of the Cape Canary is placed high up in a tree 
sible for the supply of 30,000 to 40,000 cabbages and cauliflowers, and tons of turnips, carrots, etc., and my experience has been that of many. There was never such a season when everything was overrun with insect filth, but in a most remarkable way seedeating birds like linnets, sparrows, finches, and many others swarmed down upon the fields and ate up legions. But for this there must have been an absolute famine in these vegetables."

It must be borne in mind that the cultivation of land powerfully favours an eruption of insects, and that as a consequence an unusually large number of birds are required to keep them in check.

In South Africa the migratory locust does immense damage to crops, pasturage, and forests. For twenty years and more a campaign has been waged against this mighty host. The fight still proceeds with varying success. The slightest relaxation of the pressure exerted by the Agricultural Department of Government and the farmers is quickly followed by an increase in the numbers of devastating swarms of locusts.

Here again we have cause and effect. Ever since the advent of the European settler to South Africa, the wild birds have been persecuted. The so-called game birds-such as guinea-fowl, partridge, and quail, the storks, cranes, herons, and ibises-have been harried, hunted, and slain. As a direct result of this steady reduction of their chief natural enemies, the locusts and grasshoppers have increased abnormally. Aye! truly our sins have overtaken us. Money 


\section{BIRDS}

has been spent like water in the endeavour to overthrow the enemy.

This locust campaign has already cost South Africa millions sterling in active war against this plague.

Both in Natal and the Cape I have systematically examined the contents of the crops and stomachs of birds of different species at varying seasons.

During a locust invasion I counted over 2,000 very young locusts in the crop of a white stork (Ciconia alba). Taking the number at 2,000 daily, we have 60,000 locusts disposed of in a month by a single bird.

A farmer brought in some guinea-fowls he had shot during a hunt out upon the veld. In the crops of five of these I discovered nearly I००,००० locust eggs.

The crop of a cattle egret (Bubulcus ibis) contained I,200 newly hatched locusts, 400 grasshoppers, 5 I ticks, 8 beetles, and 3 caterpillars. The crop of a bald ibis (Geronticus calvus) contained 3 I winged locusts, 760 young grasshoppers, I 78 insects of various kinds and their larvæ.

The majority of the bird enemies of locusts are migratory in their habits, and only visit South Africa from the north during the warm season of the year when insect life is abundant.

Birds are highly intelligent and timid creatures, and finding South Africa so full of human enemies, they migrate to less dangerous regions, and consequently from year to year migratory birds visit us in ever-decreasing numbers. 
For instance, the little locust bird or kliene sprinkhaanvogel (Glareola melanoptera) was to be found in large flocks every summer season in the neighbourhood of Pietermaritzburg. The youths of the city, finding the bodies of these faithful allies were good for making pies, began a campaign of extermination. Within five years not a single bird of this species was to be seen, not because they had all been killed, but, finding themselves so inhospitably received, they no longer visited their old hunting grounds. The result was a plague of grasshoppers, which for many years devastated the pasture lands and made gardening almost an impossibility.

The extermination or driving away of a single species of bird may, and often does, result in a plague of some sort.

For instance, in Australia, grasshoppers every summer season are a menace to the farmer. Should their natural enemies, the birds, be reduced in numbers for any reason, the grasshoppers rapidly multiply and lay waste the crops and pasturage.

The straw-necked ibis (Carphibis spinicollis) is the bird which is mainly responsible for holding these pests in check. A rookery of these ibises was visited, and it was estimated 200,000 birds were breeding there. Some specimens were procured, and it was ascertained by actual counting that the average contents of the crop of a single bird totalled 2,400 young grasshoppers and some snails and caterpillars: 200,000 birds would therefore dispose of about $480,000,000$ grasshoppers per day. This vast number would 


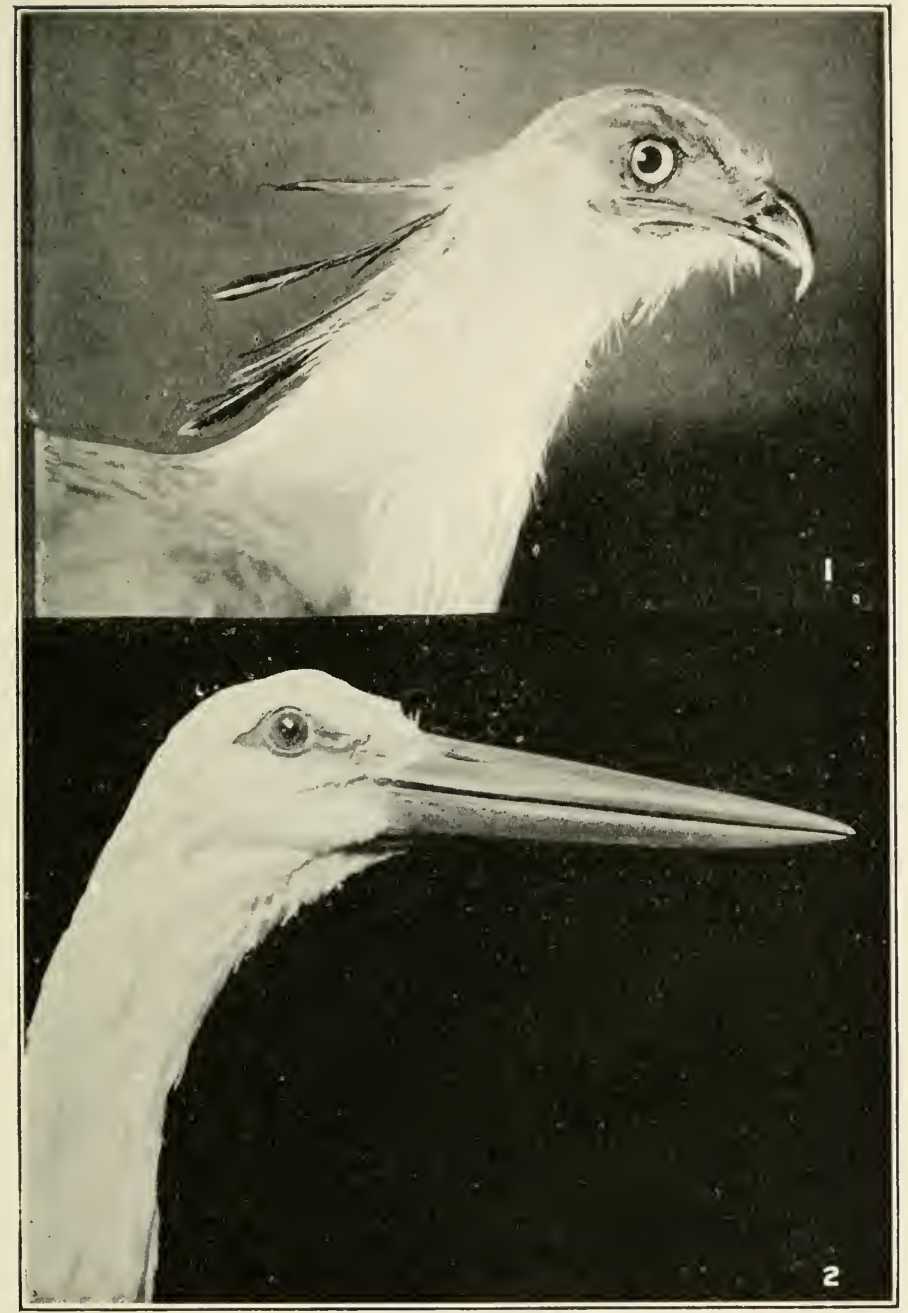

1. The pointed and curved beak of the Secretary Bird is an efficient weapon for killing rats and other vermin.

2. White Stork (Ciconia alba). The beak of a bird is a weapon of offence and defence. Also a tool with which it procures food. 
be consumed every day by the nestling birds alone, and the parent birds would necessarily have to procure a further supply for their own needs. It can thus be realised what a colossal work this one rookery of ibises was doing for man.

Without the ibises successful agriculture would be impossible in Australia. When grasshoppers are scarce the ibis feeds chiefly on a fresh-water snail,

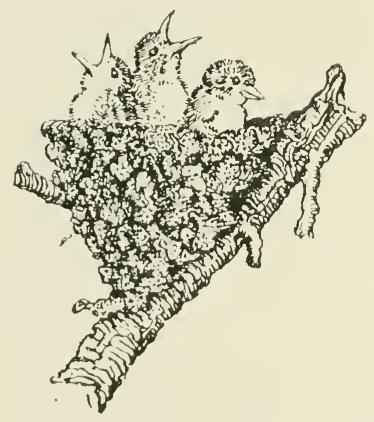

When we kill the parents the baby birds perish miserably. which is the intermediary host of the dreaded liver fluke that destroys large numbers of sheep.

"What is everybody's business is nobody's business" is a very true saying. In the instance of the ibises in Australia we see it explained, for, notwithstanding the immense services rendered to the individual and the State as a whole, people actually visited these rookeries and collected the eggs in cartloads. An instance is mentioned of a party in I 9 I 2 having gathered so enormous a quantity of eggs that they were unable to take them all away, and left 4,800 eggs to rot on the ground. Bird protection laws are useless unless the people of the country actively assist in helping to enforce the laws. An agitation is got up, and a public law is made, interest lapses. No combined and sustained efforts are made to have the law enforced. No trouble is 
taken to educate the populace into a knowledge of the existence of the laws.

Birds breed when the farmers' crops are young and tender, and when not persecuted they build their nests in the vicinity of the growing crops, knowing full well there will be an abundance of fat caterpillars on the cultivated lands for their needs. Many a time I have sat, hidden in a bush, watching a colony of weaver birds flying to and from the farmers' fields, bringing one or more caterpillars every journey for their hungry children. One pair of weaver birds made sixty journeys in two hours. Assuming each brought back one caterpillar every journey, the pair of birds would have removed 120 caterpillars from the farmers' fields in two hours. A full day's work would account for 960 caterpillars. Usually two to five small caterpillars are the result of each journey. The average accounted for in a day by a pair of birds would probably be I, 500 .

The colony under observation totalled I I 3 pairs of birds, and these would collect at least I 50,000 caterpillars a day. Yet it is a common practice throughout South Africa to permit children, both white and coloured, to rob birds' nests of eggs or young. Should he not require either, the boy gratifies his destructive instincts by pelting the nest with stones, or riddling them with pellets from an air-gun, shot-gun, or catapult. It is, indeed, high time this wanton and alarming slaughter of our feathered allies ceased. Boys are not by nature cruel. Their many brutal and sometimes diabolically cruel acts perpetrated on defenceless 


\section{NATURAL HISTORY OF SOUTH AFRICA}

animals, birds, and reptiles are due to utter lack of the proper kind of instruction.

Until economic Natural History is taught in schools, in the lecture hall, and in popular writings, the country will go on suffering from the effects of the indiscriminate destruction of our native birds and other useful fauna.

What we need is more education of the heart, or, in other words, humane education. What is humane education? It means the careful, systematic training and development of the brain centres which give rise to feelings of pity, unselfishness, and sympathy with all suffering creatures; a desire to prevent cruelty and to make the lot of others, both human and animal, as happy as it is humanly possible, by kind acts, words, thoughts, and sympathy. 'The man or woman who lives entirely for the gratification of selfish desires is a parasite upon a community-an ever-present evil example to the young. Longfellow fully realised this when he wrote:-

" How can I teach your children gentleness, And mercy to the weak, and reverence for life, When by your laws, your actions, and your speech You contradict the very things I teach?"

America is far in the lead in her efforts to teach her children their duty towards the animal folk. The educational authorities in that country are rapidly realising that cramming a child's brain with a quantity of dry facts is not education. It is certainly necessary to educate the intellectual lobes of the brain in certain 


\section{BIRDS}

ways to fit the girl or boy for her or his future career, but a man may even possess the finest university training it is possible to get, yet that man may be an a 11 round blackguard. Why? Because in such a case the moral, spiritual, and humane lobes of his brain have not been cultivated; they have been starved and consequently enfeebled, hence the man uses his educated intellect to provide ways and means for the gratification of his perverted lower passions and other

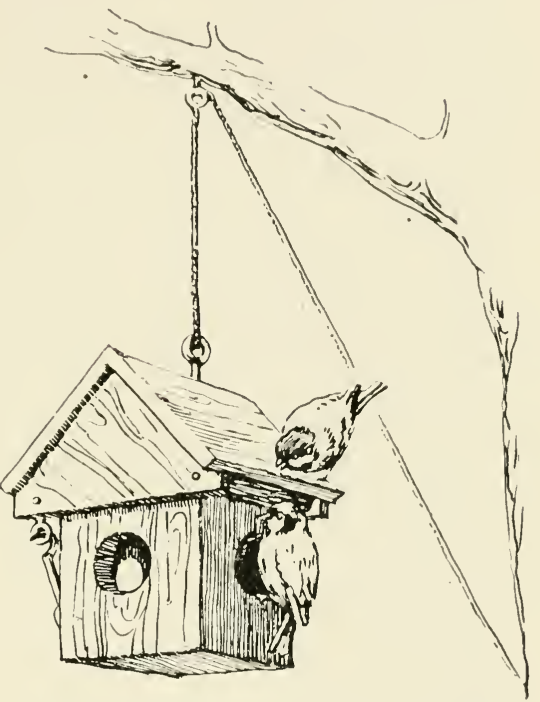

Nest box suspended from a tree. Birds cannot breed unless they have suitable nesting sites. The wise farmer provides them. selfish desires. There is deep wisdom in what Cowper says:-

"I would not enter on my list of friends-

Though graced with polished manners and fine sense,

Yet wanting sensibility-the man

Who needlessly sets foot upon a worm."

The beautiful white egret was nearly exterminated in Egypt by the plume trade. The Egyptian Zoo- 
logical Service took the matter up just in time. A worm was devastating the cotton crops, and thousands of people were being steadily but surely beggared. The Egyptian Zoological Service did not preach humanity or kindness. The natives were simply told: "A worm is destroying your cotton crops. The egret feeds on those worms. The plumage hunters kill the egret for profit and take the money out of the country. The matter is in your hands." That was enough : the egret has at last come into his own. From a few captive egrets in the Zoological Gardens fifteen egrets were hatched in I9I3. These have now multiplied and spread all over Egypt. It is universally admitted the egret has saved Egypt's population from penury and averted national bankruptcy.

If a man possesses one talent and cultivates and uses it for unselfish purposes, he is an infinitely better man than he who has two talents and uses them for the acquirement of wealth for self-gratification. Man is so absorbed in the pursuit of wealth and the gratification of personal desires and passions that he has no time for study and meditation. Does he pause and consider when he buys his boy an air-gun or shotgun? Does he ask himself what use his son is likely to make of the gift? If he considers the matter at all he will know that the impelling instinct of a boy is to sally forth and kill some defenceless creature unless he has previously received a thorough moral and humane education. To refrain from committing a harmful or dishonourable act only because of the 


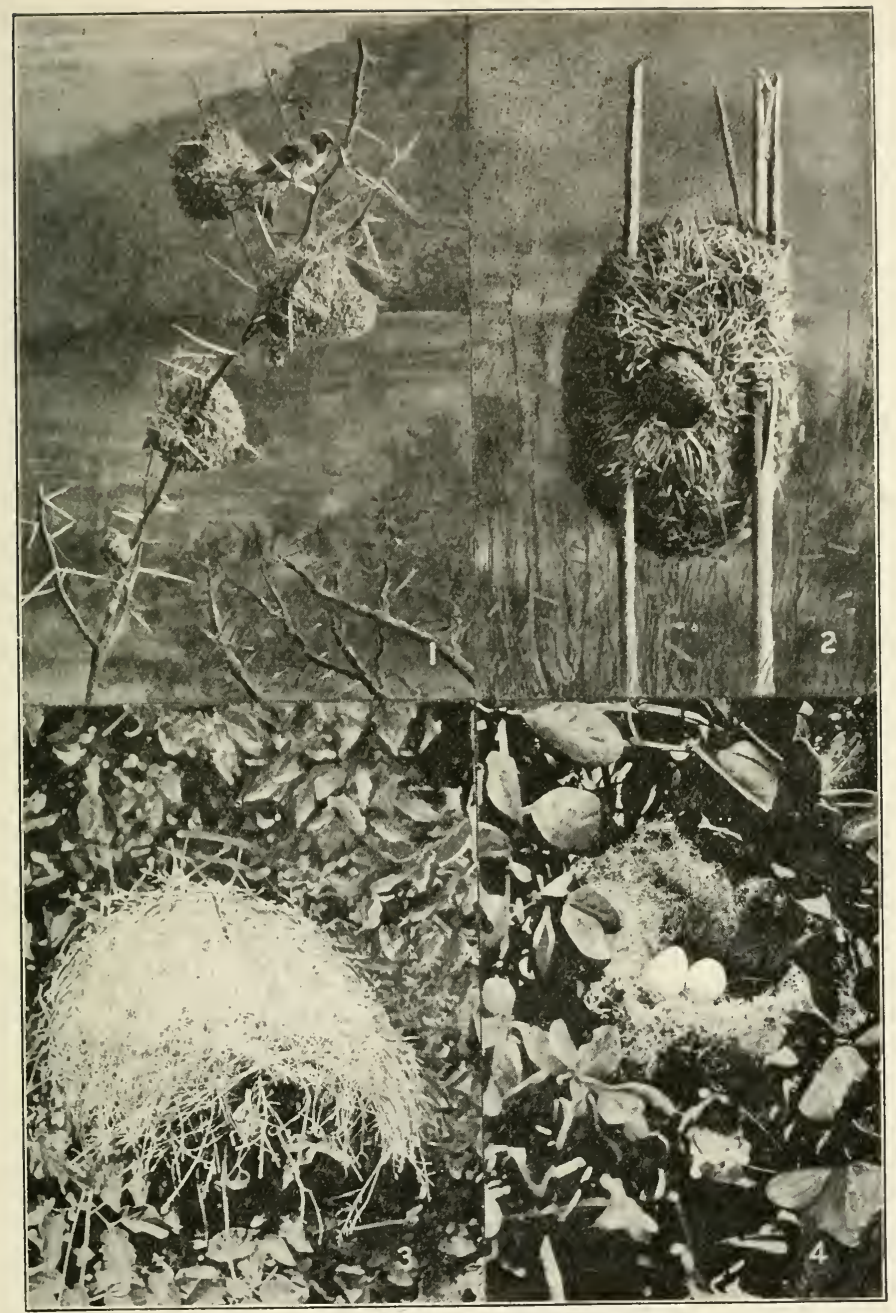

1. The Pink-billed Weaver associates in colonies, and builds small round nests on the branches of trees-usually the mimosa.

2. The Black and Yellow Bishop bird weaves a big nest of grass between two reeds.

3. The Scaly-feathered Weaver's nest is a mass of dry grass placed in a tree. The entrance hole is at the side.

4. The Black-headed Oriole builds a nest of lichen in the upper branches of a tree.

VOL. I. 


\section{NATURAL HISTORY OF SOUTH AFRICA}

fear of consequences is despicable in the extreme. It is not "cricket." It reflects no credit on a man at all. He cannot claim to be on a higher level than the sub-human kingdom of the animal creation until his actions are controlled by a developed moral and spiritual mentality.

I have seen too much of the evil wrought by

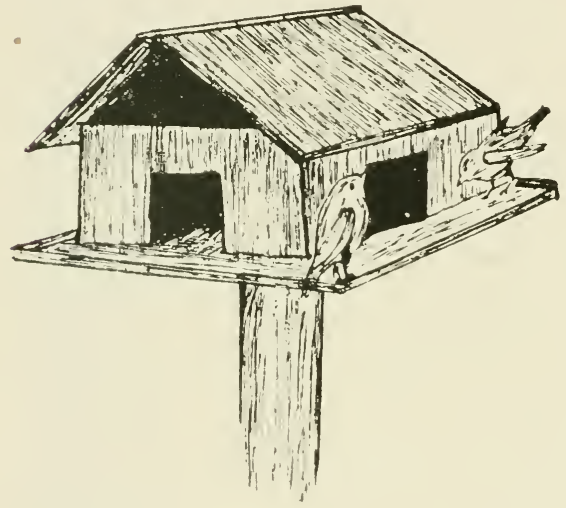

A Bird House for the garden or stoep. Birds require shelter from sun, wind, frost, and rain at times. boys with guns a mongst our feathered friends and helpers, the birds. Even the swallow and the martin, of all birds, were not sacred to them. These birds rank highest in value to man. Their sole food consists of insects and allied forms of

life which are captured on the wing. These winged insects are adult males and females which seek one another in the air for the purpose of mating. The impregnated females find out a favourable environment and deposit their eggs. Insects, with but few exceptions, lay immense numbers of eggs, therefore the destruction of one mature female insect is equal to the extermination of many hundreds and even thousands of larvæ, such as caterpillars. 


\section{BIRDS}

Martins and swallows rear broods of from four to six, according to the species. The young are fed on insects captured on the wing.

The authorities in a certain South African town objected to the "unsightly appearance" of a number of swallows' nests under the eaves and other sheltered nooks and corners on the town hall. The fire brigade was turned out, and strong jets of water were turned on to the mud nests. Over 300 were washed down with the nestling birds, which perished miserably. Taking the average number of young in each nest at four, we have I,200 young and 600 adults. Each family destroys on an average 2,000 flies, gnats, winged weevils, and aphides in a day. It will thus be seen this little colony of swallows destroyed more than one million insects daily. These were taken in and near the vicinity of the town. Comment on the action of the authorities of that town is needless.

Mr Eustace Montgomery, the late Director of Veterinary Research in South Africa, stated in I9I9 that the annual losses of stock farmers in the Union of South Africa from preventable diseases were not less than $f 8,000,000$.

These stock diseases, with but few exceptions, are due to injection of disease microbes through the mediumship of insects and allied forms of life. This does not end the trouble. Our indifference to the welfare of our bird allies results in an abnormal increase in the numbers of insects which destroy pasturage and crops, bringing about an insufficiency of food for stock animals. The lucerne caterpillar, for instance, 


\section{NATURAL HISTORY OF SOUTH AFRICA}

attacks and demolishes great fields of beautiful green lucerne. The army moth caterpillar blasts the veld and crops as by fire. Clouds of migratory locusts in the winged and wingless stages eat up both crops and pasturage. Hundreds of other destructive pests take their unearned share of food which ought to be available for our stock animals.

We have great ideals, aye! beautiful dreams of South Africa's fair lands sustaining a population of twice and many times more than its present number. But do we combine and utilise our available resources to bring our ideals to fruition? No! we may be aptly compared with the farmer who possesses a hundred fertile acres and only makes use of half a score of them.

The United States Department of Agriculture has estimated (I92I) that insects damage the nation's crops to the vast extent of 2,000,000,000 dollars annually. The Entomological Branch of the Canadian Department of Agriculture say that insects cause a loss of at least $f, 25,000,000$ to their country.

When will man cease to slay his feathered soldiers and policemen? The injustice, the brutality, the stupidity of his action in destroying his feathered friends and allies is inexcusable. There is no excuse for ignorance. Ornithologists and entomologists have raised their voices in protest, but they are heeded not. Men turn a deaf ear and continue to pursue the methods of their uninformed ancestors. The men who retard human progress most seriously are those who are ignorant of their ignorance. What is urgently 


\section{BIRDS}

needed is to teach the people the value of our native birds, and to provide the necessary machinery for the enforcement of bird protection laws. In South Africa the majority of wild birds are under the protection of the law, but no efforts are made to either enforce these laws or to educate the school children on the subject.

How long are we to allow these allies to be at the mercy of the trap, the snare, the catapult, and the gun of the ignorant? Just so long as we permit this unreasoning and callous slaughter of our birds, we shall have our crops, our orchards, our pasturage, and our forests riddled and damaged by the insect armies.

Birds seek out and devour the worms in the wood, the caterpillars on the crops, the aphides on the shrubs, the fruit and disease-carrying flies in the air, the wireworms and other larvæ underground, and pests which are wounding and slaying all forms of useful plant life. In Canada and the United States of America strong efforts have been and are being made to reduce the gigantic losses which are caused by the depredations of insects. It is estimated (I9I 5) that the birds of Nebraska eat I 70 cartloads of insects a day. This was the calculation of an eminent naturalist. He also estimated that the birds of Massachusetts destroyed 2 I,000 bushels of insects daily; and a single species of hawk saved the farmers of the Western States I 75,000 dollars a year by destroying grasshoppers and field mice.

When you take life away with one blow, do you not sometimes think how powerless you are to make 
live again that which you have killed? When you kill a bird, does not remorse sometimes overtake you when you think what a miracle of machinery you have stopped by a thoughtless act?

"We pass through this world but once. Any good we can do, therefore, or any kindness, let us do it now, for we shall not pass this way again."

\section{BIRDS AND THE ORCHARD}

OLD colonists in South Africa all tell the same tale of how, long ago, the fruit trees were laden with good, sound fruit. Now, the fruit grower in order to obtain even an average crop, is obliged to wage unceasing war on the hosts of insects which devour the trees or lay their eggs in the ripening fruit, rendering it maggoty and useless. Should he grow careless and become slack in his offensive or defensive measures, his crop is ruined. Nearly all this mischief started in and near the towns and villages. Boys and even grown men wantonly persecuted the birds and robbed their nests, and the latter, in consequence, became increasingly shy and scarce. The disappearance of the birds brought about an abnormal increase of the various insects which attack fruit trees and the ripening fruit. Larvæ of beetles tunnel the trunks and branches; caterpillars and certain species of beetles feed on the foliage; flies and moths lay eggs in the fruit. Farmers, in their anxiety to destroy the fruit-eating 


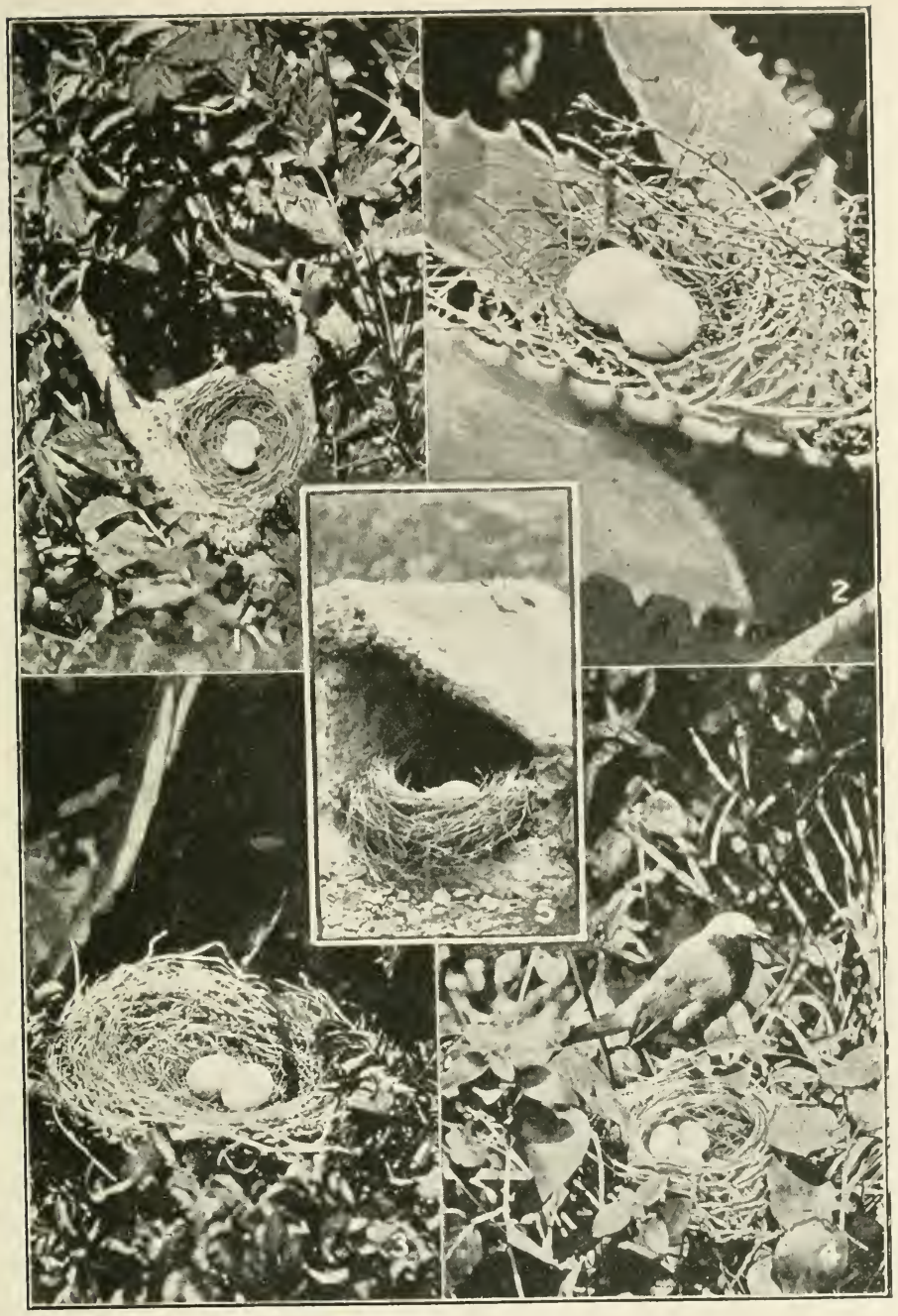

1. The Drongo weaves its nest between two branches.

2. The nest of the Turtle Dove is a flimsy structure of twigs and rootlets

3. The nest of the Tchagra Bush Shrike is built in a thick bush.

4. The Bakbakiri Shrike rears its family in a nest in a low shrub.

5. The Cape Rock Thrush builds its nest among rocks, or under a stone. 
birds, such as the muis vogel and bulbul, used little or no discrimination. The sight of a bird in the fruit trees is proof to them it is a pest. Even should a man confine himself to shooting true fruit-eating birds, the frequent discharge of his shot-gun will damage the trees and terrify all the birds in the neighbourhood, causing them to abandon the locality for a safer habitat. Unless other means such as pellet guns are used, it is often more profitable to allow the fruit-eating birds to take a toll of the fruit than to lose the entire crop and risk damage to the trees themselves by insects and their larvæ.

If decoy bulbuls and muis vogels are placed in cages and limed twigs are placed over or near the cages, considerable numbers of these birds may be caught. Another method is the trap cage. The mouse bird or muis vogel can be destroyed in three ways :-

I. Injecting a solution of strychnine into ripe fruit. This is a rather risky proceeding, and may easily lead to accidental poisoning of children.

2. The muis vogels have a habit of roosting in a bunch, clustering like a swarm of bees. If their roosting place can be located, a single charge of small shot will destroy a large number. . On cold, cloudy days they may often be seen in clusters in the fruit trees.

3. The most efficient way is to trap them. The trap is a simple contrivance, and is made of $\frac{1}{2}$-inch mesh wire netting stretched on a frame of No. 6 or No. 7 fencing wire, and fashioned like an eel trap with a funnel at one end. Some fruit is placed on a 


\section{BIRDS AND THE ORCHARD}

hook, made of wire, inside the trap, and the trap is placed in a fruit tree or in a tree near the orchard. The muis vogel being a climbing bird, the trap should be placed with the funnel end below. If put in a fruit tree, a branch with fruit on could be pushed into the trap. The trap should be about 3 feet by $\mathrm{I}$ foot. Fruit growers should have several of these traps in various parts of the orchard.

The persecution of birds in the neighbourhood of towns and villages and on some farms has now resulted in South Africa being absolutely overrun by

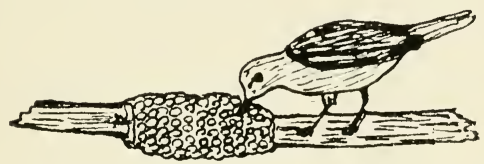

Biris clear the twigs of clusters of insects' eggs.

fruit and tree destroying insects. Man seeks by costly, and at best very imperfect, ways to stem the invasion, but in the end his efforts prove futile. Already fruit growing is being abandoned because it entails so much expense and expenditure of time in combating the hordes of insects which swarm down upon the orchards. The rescue of the fruit industry from eventual extinction rests with the native birds. In the bird army we have an efficient ally in our fight against the insect fruit pests. It is not recommended that we cease our manifold artificial methods of attack and defence against the enemy. Let us also avail ourselves of the help which the birds can render. 
All they ask is protection. Then, why not be up and doing? It is not enough that we individually refrain from persecuting the birds. We must combine and protect these valuable helpers from molestation by ignorant, irresponsible, and morally degenerate folk.

Before raising his hand in anger against any bird, the fruit grower should ponder well, lest by the removal of one evil he brings a greater upon himself. Some species of birds supplement a large insect diet by a little fruit, or devour it only in times of drought when no water is available; others peck the seeds from fruit already partly eaten by true fruit-eating birds or beetles; others, again, attack maggoty fruit and feed on the maggots, fruit flies, and beetles, and not the fruit. Some birds peck off buds now and then, but no species of South African bird is, so far, guilty of this crime to any very serious extent. When the English house sparrow (Passer domesticus) increases abnormally, it does considerable damage to budding fruit trees, and at times it becomes necessary for man to considerably reduce the numbers of this rapidly breeding bird owing to its natural enemies having been practically exterminated in Great Britain.

A man who grows fruit as a hobby, or who is backed up by large capital, may possibly ward off the attacks of insects to a limited extent by artificial means; but, nevertheless, he has no moral right to use his influence to deprive the poorer class of fruit growers of their only ally, the birds.

Buckland mentions an instance of man's hasty 


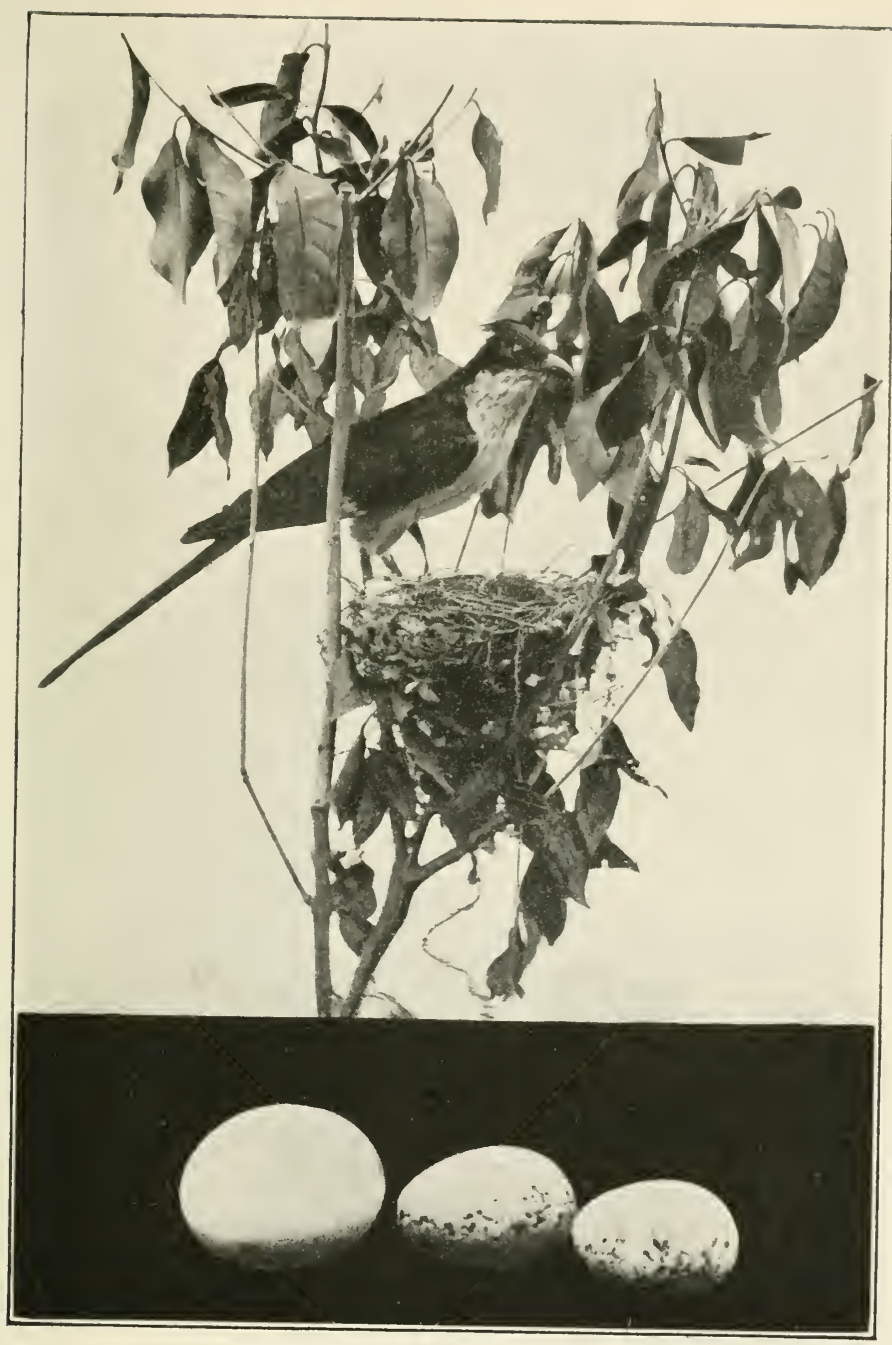

Black and Grey Cuckoo (Coccystes phyopinarius) at the nest of a Cape Bulbul (Pycnonotus capensis). This cuckoo laid a large white egg in the bulbul's nest, and, taking one of its host's eggs in its mandibles, it flew away.

The Cuckoo's egg, and the two eggs of the bulbul, are shown in the illustration.

This happened on 1Sth December 1919. 
judgment, and the result. Frederick the Great of Prussia, angered because a flock of sparrows had pecked and spoiled some of his cherries, issued an order that every small bird on his estate be searched out and killed. Within two years his beloved cherry trees were bare of fruit, but heavily weighted with caterpillars instead.

The only fruit-eating birds which do not earn their wages to my knowledge are the coly or mouse bird (Muis vogel), the bulbuls, known as the kuifkop, geelgat, topknot, black head, and tiptol.

In some localities the red-winged starling or rooivlark (Amydrus morio) ravages the orchards.

Poisoning fruit to kill fruit-eating birds is often a harmful and wasteful practice, because large numbers of birds are poisoned which resort to the orchard to peck at fruit already damaged by the true fruit-eating birds, beetles, flies, and maggots. I have seen woodpeckers and other eminently useful insectivorous birds lying dead under trees, some of the fruit of which had been poisoned.

The following experience of the owner of a large cherry orchard in Kent, England, is interesting reading :-

"Two men were constantly employed in the early summer to shoot bullfinches, chaffinches, woodpigeons, and indeed every bird that dared to chirp. An ominous stillness pervaded the orchard and, notwithstanding the money wasted in labour, powder, and shot, the crops were far below the average, owing to the depredations of thousands of caterpillars that fed 


\section{BIRDS AND THE ORCHARD}

upon the young fruit buds and in due course upon the leaves, hanging by silken cords from the branches. In this case it would have been better and cheaper to have left the birds alone rather than to have cultivated such a magnificent crop of caterpillars. These, of course, carried on the mischief on a much more extensive scale the following year."

Mr Joseph Witherspoon, of Red Rose Vineries, Chester-le-Street, writes as follows :-

"Of that class of people, forming so large a portion of our population (in England), who never bestir themselves save when their interests are attacked, birds have much reason to complain. With them a bird's existence is ignored, save during the short period of the year when, undoubtedly, they do consume somewhat of that which is of more or less value. It was my fortune to be reared in a school where birds were certainly not regarded as friends. My father, a market gardener, encouraged me to destroy every nest I found; and it was possessed with much the same feeling that, after being engaged in other pursuits for thirty years, I returned to the calling of my boyhood, and also commenced growing fruit under glass. I soon discovered that insects were seriously destructive both inside and outside, and believing that a good sharp frost would rid us of the latter, I longed for a hard winter. The following winter we had 39 degrees of frost, or below zero. Even fruit trees of some varieties were killed, and as for birds, in some places they were all but extinguished. From this period, sixteen years ago, you may date my becoming a close 


\section{NATURAL HISTORY OF SOUTH AFRICA}

student of the habits of birds, as, with the thrush tribe all but annihilated, the following summer snails were a scourge, gooseberry bushes were stripped by innumerable caterpillars, and all trees that had been injured by the frost had their sickly foliage proportionately devoured by the red spider.

"For the protection of my one and a half acres of trees and fruit bushes, situated some 600 yards from the town, I have within the vinery walls about twenty-five pairs of sparrows, and my gooseberry bushes are never touched. As for sparrows eating the blooms, I have, as yet, only heard of the performance. These are stern, unattackable facts. During the first year, after the serious frost referred to, I dusted my bushes with hellebore powder. Amid the shoals of dead caterpillars that lay under every bush I discovered several dead sparrows, which had been killed by eating the poisoned pests, and so I had it proved conclusively that they did eat the gooseberry caterpillar.

"Birds that are fed on the premises, and that live and feed amongst the trees, search for and attack the larvæ of grub at every stage of their existence. I attribute much to having birds bred, and always near, where you want them, for such never attack buds ravenously, as do town-bred birds, the latter not being able, so situated, to secure the green food necessary for their health. With gooseberry bushes near a stackyard you will probably find, especially during a snow storm, that the want of green food has compelled the birds to eat the buds. Also in early spring, in 


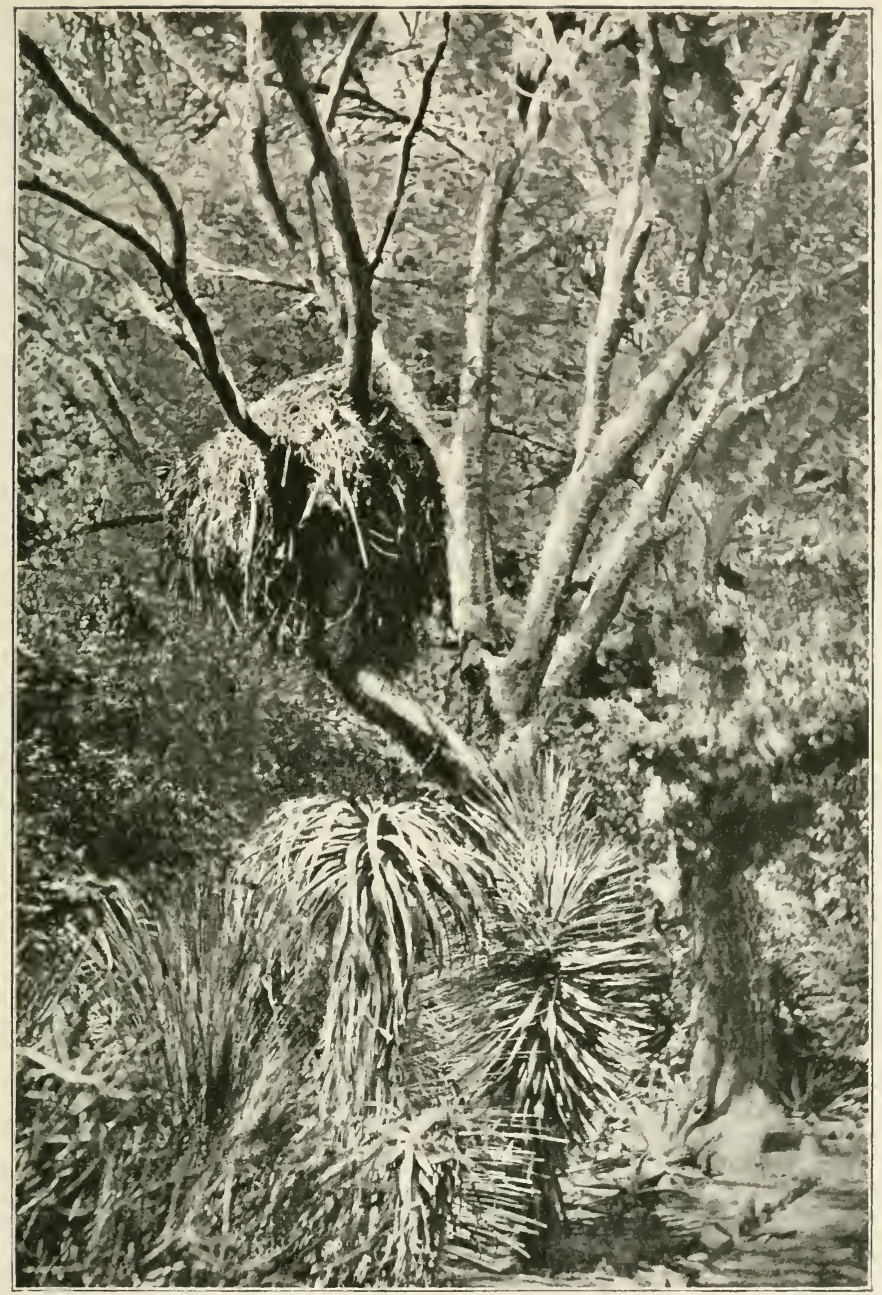

Nest of a Hammerkop or Mudlark (Scopus umbretla) in St George's Park, Port Elizabeth.

It is composed of bark, twigs, bits of paper, rags, and straw, and would fill a Scotch cart. 


\section{NATURAL HISTORY OF SOUTH AFRICA}

the neighbourhood of large towns, the conditions being similar, everything that is green will be sought for. Likewise, when gardens are surrounded by woods, it is only by a liberal use of nets that any reasonable portion of the fruit can be saved. I provide nesting places, and thus have birds so near to the caterpillars and so far away from house morsels, that they devour the pest greedily. But fruit crops being thereby secured, we must next draw on our ingenuity to prevent the birds taking more than their fair tithe. Birds are very destructive to corn when in the milk state, and fields, situated near towns, suffer severely. Had I such a field I would set two school children, the one from 4 A.M. till $\mathrm{I} 2$ and the other from I 2 till 8 P.M., each having a crake, to drive the birds away. If the children cost, say, $f_{\text {, I }}$ for the fortnight, I should perhaps save from $f .5$ to $f, \mathrm{I} O$ of a crop which, but for the birds, would be non-existent.

" In part justification of those who would exterminate birds, it must be admitted that for perhaps six weeks in the year, crows, blackbirds, and sparrows are especially destructive; but if cultivators would concentrate their efforts to 'keep them moving' at such times to other fields, then they would not be injurious, and their services would so be secured for the longer period, the great value of which will only be known when thousands of grubs are allowed to breed and devastate through our ignorantly tampering with the necessary balance so wisely provided.

"As to the hard-billed tribe of birds which destroy the seed beds, the gardener must protect his beds with 


\section{BIRDS AND THE ORCHARD}

nets, as these species live mostly on seed all the year round; indeed, we cannot but be witnesses to the vast swarms that feed on stubbles and fallows during the winter months without thinking that were it not for these birds eating myriads of the seeds of choking, impoverishing weeds, our corn crops in thousands of cases would not be worth the gathering.

"Since writing the above, with a further season for close observation, I offer a few more remarks on the labours of my feathered favourites. Whilst many fruit growers have been racking their brains to discover still more poisonous compounds for the destruction of the apple weevil and other insect pests, I have again found my birds quite equal to the occasion. My apple crop, in fact, has been so well preserved that I do not remember to have met with even one fruit disfigured by insects; this, too, after, by the aid of a microscope, discovering many more maggots than I expected to find. Sure enough the enemy were in possession, and the battle was rather tough; but, all in good time for the fruit crop, the brave birds brilliantly conquered. In connection with my occupation there are three things that I love to see, viz., crows following the plough, ducks (under two months old) in either vinery or orchard house, and sparrows, especially during the blooming period, feasting and holding high converse in an apple tree.

"My advice to all is : Think long, think seriously, and search deeply before attempting to upset the laws of Nature or disturb the balance of forces

VOL. I. 


\section{NATURAL HISTORY OF SOUTH AFRICA}

established by the Great Designer and Maker of the Universe.

"The last season I have had further confirmation of the great value of birds, as within fifty yards of my sparrow colony my apple orchard has been the wonder of the neighbourhood, and numerous visitors have come from adjacent towns to see the sight, all declaring they never saw the like before."

"Think every morning when the sun peeps through

The dim, leaf-latticed windows of the grove, How jubilant the happy birds renew

Their old, melodious madrigals of love! And when you think of this, remember, too,

'Tis always morning somewhere, and above The awakening continents, from shore to shore, Somewhere the birds are singing evermore."

LONGFELLOW.

\section{BIRDS AND THE GARDEN}

'THE garden and cultivated farm are ideal places for insects to breed and multiply in. Moths, butterflies, and certain kinds of beetles always deposit their eggs in the most favourable spot for the development of their grub and caterpillar children. Therefore it is only natural that by day and by night these winged pests should flock in from mountain, forest, veld, and valley to deposit their eggs amongst the succulent 


\section{BIRDS ANI) THE GARIDEN}

plants of the garden or green waving corn or wheat of the fields. The eggs hatch and the larvæ instantly begin their attacks on the vegetation, each according to its kind. Some burrow underground and feed on the roots; others bore into the stems of plants and eat out the pith ; others, again, attack the foliage, the bud, or unripe grain or fruit. 'These brigands are wily. They employ many clever devices to deceive and to escape the attention of the owner of the produce they are bent on devouring. In his tours of inspection, or when labouring in the fields during the daytime, he

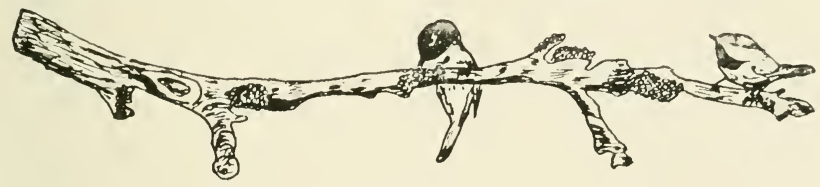

Cleaning twigs of clusters of insects' eggrs.

sees but few, if any, of his enemies. The birds, however, from long generations of inherited experience, know the crafty ways and dodges of these thieving rascals. At the first streak of dawn the birds are out and busily searching the ground and vegetation before the caterpillars have sought a place of concealment beneath the loose soil, decaying leaves, grass, behind bark, on the under side of the leaves, etc. Again, at sundown the birds await the reappearance of the robbers and snap them up. In fact, except during the hottest part of the day, birds are busily searching for their insect prey, merrily chirping, twittering, and calling affectionately to one another all the time. 
Wise Nature, knowing that the insect army in richly cultivated fields is at times likely to gain the upper hand in spite of the constant onslaughts of birds during the daylight hours, has provided another powerful check.

Moths fly by night and lay thousands and tens of thousands of eggs during the hours of darkness. One female moth, therefore, is capable of producing a small army of caterpillars. Every moth destroyed before it succeeds in depositing its eggs is equal to killing five hundred or a thousand caterpillars.

The night jar (Caprimulgus), variously known as the night hawk, goat-sucker, nachtuil, has been specially evolved by the Creator for the purpose of preying on insects which fly by night. Emerging from its leafy retreat at dusk, it is on the hunt the entire night, and its labours do not cease until dawn. The number of insect pests it destroys is enormous. When flying insects are in insufficient numbers to satisfy its needs, it seeks others on the roads, pathways, and other bare spots, surprising them while they are in the act of travelling to seek more succulent vegetation, or a suitable place in which to hide and change into the chrysalis state preparatory to issuing forth as fullydeveloped winged insects.

From an analysis of the stomachs of a number of night jars, the following one may be taken as an average example :-

80 moths; $4^{6}$ beetles; 8 caterpillars; 2 I insects of various species.

Taking half the moths and beetles to be females, 


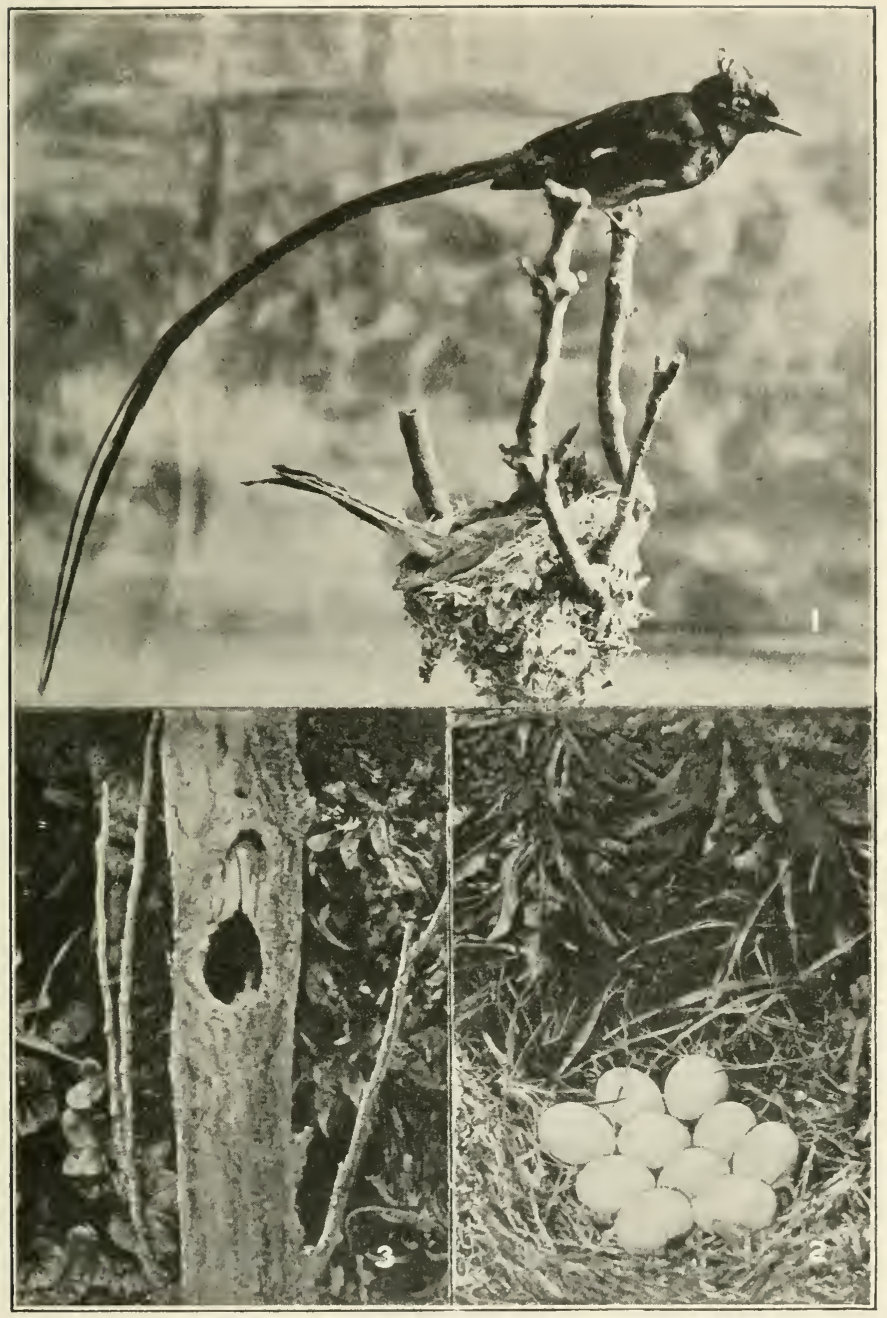

1. A pair of Paradise Flycatchers and nest. The nest is made of lichen, cobwebs, and moss.

2. The Red-necked Bush Pheasant lays from 8 to $20 \mathrm{cggs}$ in a nest on the ground in the midst of dense scrub, long grass, or weeds. The chicks are active from birth.

3. The nest hole of a Woodpecker in a dead tree trunk. 
and estimating that each would lay 500 eggs, we have a total of 3 r,500. Multiplying this by thirty, we have the enormous total of 945,000 noxious insects destroyed in a month of thirty days by a single night jar. Yet, in an idle moment, or to gratify an insane desire to kill, or impelled by superstition, a man will deliberately shoot down such a bird. If the harm fell solely on that man's head, then there would be some cause for gratification in the knowledge that the guilty party had paid the penalty. Unfortunately, the harm falls upon the community generally. During the summer season in South Africa the destructive termite, popularly known as the white ant, sends forth vast swarms of fertile winged males and females to spread over the land and found new colonies. These often issue forth in uncountable hosts on warm nights, and the night jars get busy and gorge themselves on the soft, milky bodies of these terrible pests. Every pair destroyed means one colony less. A single colony of these termites is capable of doing damage to the extent of thousands of pounds sterling by eating fencing posts, the woodwork of houses, destroying the roots of plants, shrubs, and trees, as well as stored fodder ; and, in fact, anything dry of a vegetable and animal nature. The ravages of the white ant in South Africa seriously impede the development of the country, therefore the life of any creature which preys largely upon this pest should be held sacred, and there is no better ally than the night jar. This bird is absolutely harmless to man, asking nothing at all from him for its services except freedom from 
persecution, so that it may the more efficiently succour him.

In the Farmer's Weekly, 22nd August I9I7, the following paragraph appeared :-

"A plague of mice is devastating the Low Country and destroying crops in every direction, reports the New Agatha correspondent of the Zoutpansberg Review. As one passes along at night they quelch under the horses' feet. 'Traps are being set in every direction, and in one field the writer saw over fifty traps set, but it does not seem to help. Unless the plague ceases quickly, every bit of grain will be eaten up. It is said that few snakes have been seen this season, but whether this fact has anything to do with it or not is not known."

In another issue of the same journal a farmer wrote complaining bitterly of the hordes of rats and mice which were causing extensive destruction to his crops, young plantations, and orchards. Poisons and traps had failed, and he was in despair.

Here, again, we have cause and effect. The owls, hawks, and snakes, which are the natural foes of these destructive rodents, had been destroyed in such numbers that the balance of Nature had been upset, and man was called upon to pay the penalty.

A small piece of land was specially ploughed and a few hours later a black crow, or African rook, was shot on it. We opened the crop and counted thirtyeight skins of root-devouring beetle larvæ in it. Yet this bird is counted by the agriculturist as a pest. 


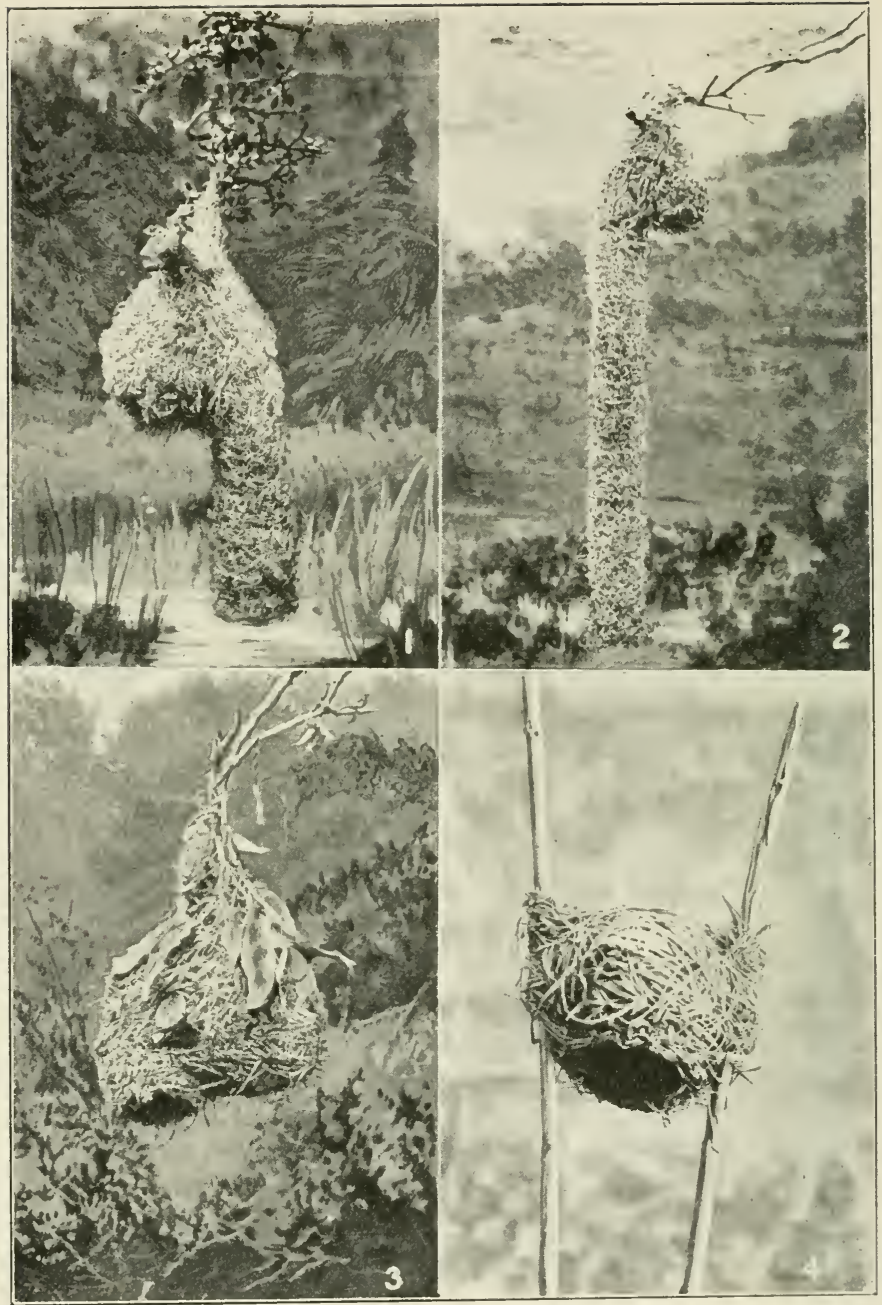

1. Nest of Smith's Weaver Bird, with the entrance tube of usual length.

2 . Nest of Smith's Weaver Bird, or Bottle Fink, with unusually long entrance tube.

3. The Spotted-back Weavers associate in colonies, and build their nests from the extreme ends of branches.

4. The Yellow Weaver attaches its nest to two water reeds. The entrance hole is under the front part of the nest. 


\section{BIRDS AND THE GARDEN}

In the large gardens surrounding the Port Elizabeth Museum we have a pair of Stanley cranes, otherwise known as blue cranes. The gardens used to be swarming with snails (Helix adspersa), slugs, caterpillars, and underground larvæ. To-day no insect life is to be seen, and for the past three years these two cranes have sufficed to keep the gardens free of all species of insect pests, excepting scale and blight.

One man may encourage birds in his garden or on his farm, but if his neighbour persecutes them they become so shy and timid that the sight of a man sends them flying off to their retreats in terror. The consequence is, the intelligent and humane farmer suffers equally with his neighbour, for the frightened and nervous birds pay his garden and fields but a hurried visit at daybreak, and snatch up a few caterpillars and fly off in hot haste before their arch-enemy, who should be their protector, is out and about. These birds, if protected, would have remained and fed on caterpillars and other noxious insects all day

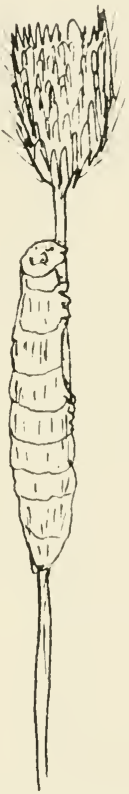

The birds feed their young on the caterpillars in the wheat.

long. Thus does man prepare a scourge for his own back. Sometimes a bird is seen busily digging with its bill on recently planted ground for the dreaded cut-worms which feed so voraciously on the tiny shoots before and just after they emerge from the 


\section{NATURAI, IISTORY OF SOUTH AFRICA}

ground. The conclusion invariably arrived at is that the bird is digging up the germinating seed, and sentence of death is hastily passed on it. Perchance, after much exhausting toil, a bird fails to satisfy its hunger on cut-worms and caterpillars, and is seen to take a few peas or some grain. This evidence, to the average human observer, is sufficient justification for destroying the bird and all its species, although for every seed it eats a thousand are indirectly saved by it. For instance, we will take a large field of wheat as an illustration. From the time the seeds germinate until the crop is ripe for reaping, cutworms, other grubs, caterpillars, grasshoppers, and beetles are steadily devouring it. A caterpillar will eat at least fifty young wheat plants in the course of a single day or night. One small bird will destroy r०० caterpillars a day when they are young, and ten times that number if it has a nest full of babies. So, if a bird destroys Ioo caterpillars in a day, and if a caterpillar eats fifty wheat plants, then the bird is saving 5,000 wheat plants every day, or I 50,000 in a month, from destruction. Should the bird be feeding five nestlings at the same time, a minimum of half a million wheat plants would be saved in a month. Not only this, but if those caterpillars had come to maturity they would have changed into butterflies or moths, and the next generation of caterpillars would have multiplied at least a thousandfold. This, then, represents a portion of a breeding bird's labours for the farmer. When the wheat is ripe, and if it be one of the grain-eating 


\section{BIRDS AND THE, ( NARIDEN}

species, it will perhaps seck some slight payment for its long and arduous services. It will probably be satisfied with two heads of wheat per day. Is this a heavy wage for a bird that has been the means of saving a minimum of 5,000 stalks of wheat a day for six or eight weeks? Is this feathered labourer not worthy of his hire?

An observant gardener, after thirty years' experience in the cultivation of fruit, flowers, and vegetables, says

"Often and often I have known rooks and starlings charged with pulling up wantonly row after row of young broad-bean plants, and it is only when I have pointed out that all the plants had been previously attacked with the terrible ground pest, the wire-worm, that a more friendly view has been taken of the mischief, or so-called mischief, done by the birds. Precisely the same thing happens in cornfields, and the seedling wheat, etc., is strewn aboutevidence as strong as holy writ. By good cultivation rather than by adventitious means, allowing birds a free run of the farm, and by placing water at their disposal, the wise farmer or gardener will leave most of the birds to carry out their natural functions, which are largely for his particular benefit.' 


\section{BIRDS AND PASTURAGE}

To the stock farmer, birds, with the exception of eagles, are an unmixed blessing. 'They ask of him no return for their services in keeping in check the insects and rodents which would otherwise devour the pasturage. When for any reason birds are reduced in numbers below the normal requirements of Nature, insects, rats, and mice multiply and become a plague. Miles of country may thus be spoiled or reduced considerably in value from a stock-feeding point of view.

In Natal, many years ago, a storm of icy cold wind and rain continued for an entire day and night. Stock and poultry died of cold and exposure in tens of thousands. The mortality amongst wild birds was enormous. Before the storm the forest groves, valleys, and fields were alive with birds, and their cheery calls echoed everywhere. After the storm the survivors crept out from their retreats, cold and hungry, and for two years birds were comparatively scarce. The blizzard occurred during the winter. The following season and the one after that were the worst the farmers, gardeners, fruit and flower growers had ever experienced. In the absence of birds, the insect hordes increased and swarmed everywhere. I happened to have several acres under cultivation, but the grasshoppers swarmed in such numbers that not a single plant reached maturity. Kitchen gardening was equally hopeless, for the instant the plants 


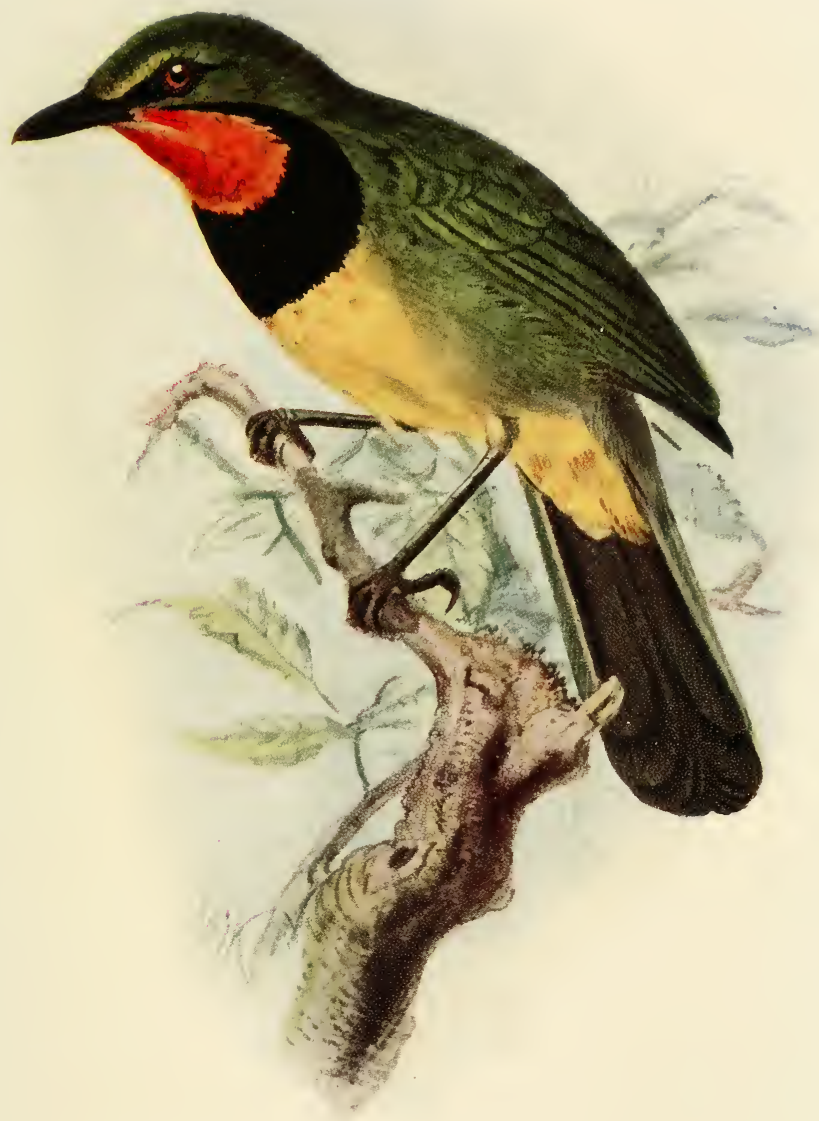

Plate III. - Bacbakiri Shrike (Lamarius gutturalis).

The Shrikes protect our gardens, orchards and plantations from the attacks of insects 



\section{BIRDS AND PASTURAGE}

pushed their heads above ground they were eaten off by these voracious grasshoppers, which in a day consume ten times their weight in vegetation. Four acres of lucerne were attacked by a countless swarm of green caterpillars, and every leaf found its way into the inside of a caterpillar. Insects were in myriads on the veld; native trees and shrubs suffered heavily. Migratory birds arrived and helped to check the enemy's advance until the native birds had once again increased sufficiently to hurl back the foe. The loss indirectly occasioned to the farming industry by the destruction of bird life in that blizzard was enormous.

In the neighbourhood of Port Elizabeth the pasture lands for several seasons in succession were invaded by hairy caterpillars which swarmed everywhere. They devoured both grass and shrubs, and invaded the vegetable and flower gardens. My grounds were a sanctuary for birds, and in consequence they congregated, bred, and slept there in large numbers. I kept the birds under careful observation, and found the only one which attacked and ate this uninvitinglooking caterpillar was the silent bush robin, otherwise known as the black and white flycatcher (Sigelus silens). This is a sociable little bird, and it builds its nest in situations easily accessible to the egg-hunting boy. Consequently its little home is raided and robbed on a wholesale scale every breeding season. The adult birds are persecuted and killed by boys at all times. Some kill them wantonly, but the majority relentlessly persecute these eminently useful 
birds under the erroneous belief they are fiskal shrikes, they unfortunately having a superficial resemblance to that bird. The fiskal shrike, otherwise known as the jack hanger or butcher bird, is hated by boys because it

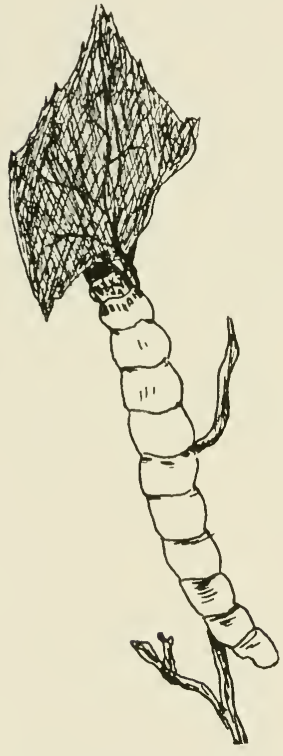

Caterpillars eat up the pasturages. sometimes kills pet cage birds by settling on the cage and seizing them between the wires in its powerful bill, with which Nature has provided it for its mission in life as an insect destroyer.

The reduction of the silent bush robins resulted in a plague of these hairy caterpillars, and considerable damage was done every spring to pasturage and gardens, all because of the thoughtlessness of boys due to lack of proper teaching.

In various parts of South Africa, principally in the neighbourhood of villages, I have seen large areas almost denuded of vegetation by grasshoppers, cut-worms, and caterpillars. The mischief does not end with the loss of pasturage. Rain falls, and the water rushes rapidly off the hard, sun-baked surface, and on its way to the nearest spruit or river it cuts fissures which develop in time into large dongas and carries away the soil, leaving stones and pebbles in its wake. 


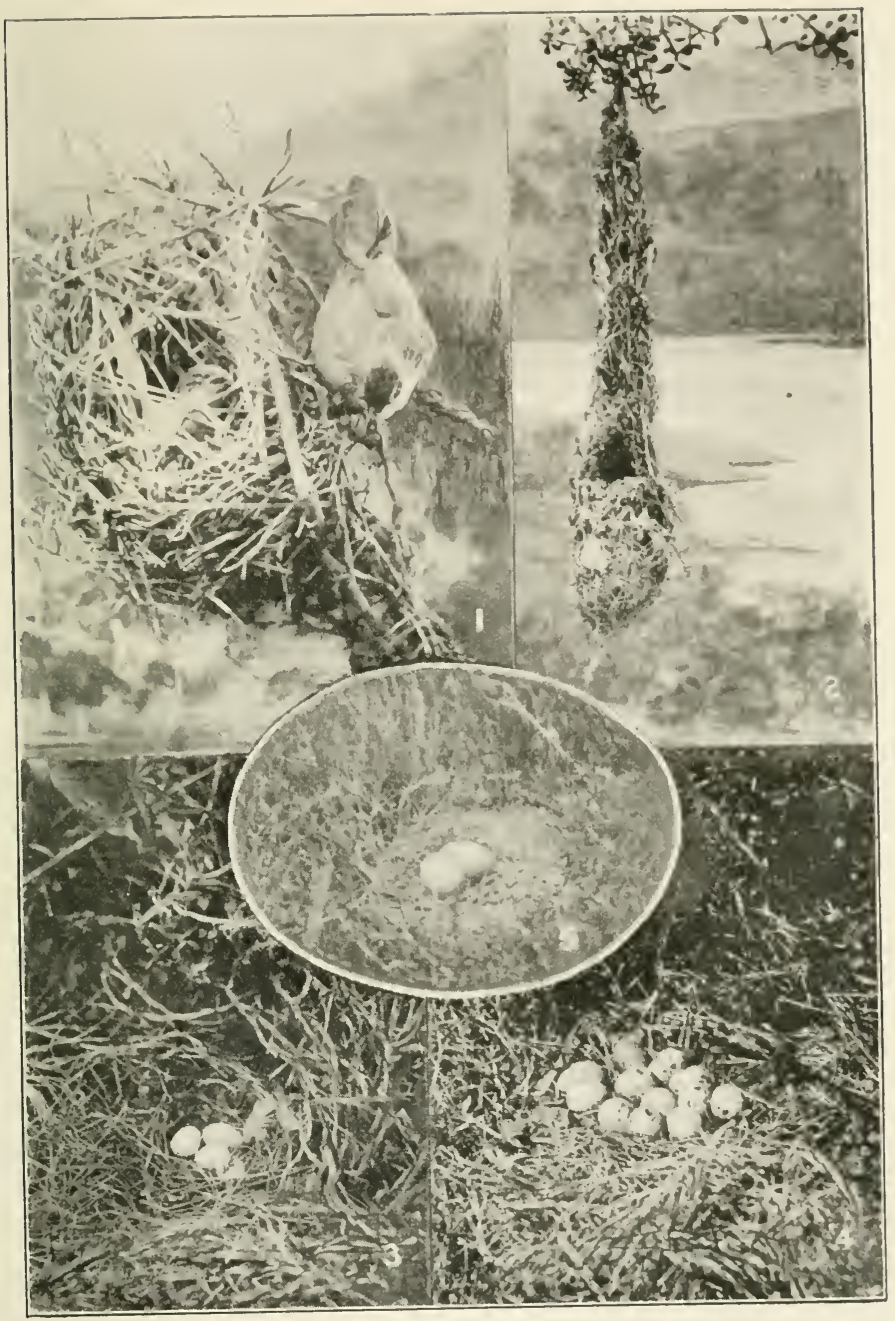

1. The nest of Burchell's Coucal, or Vlei Loeric.

2 . The IIoneysuckers make their nests of cobwehs and lichen.

3. The Cape Longelaw makes a nest on the ground.

4. The Quail also lays her eggs on the ground.

J. Nest of the Stanley Bustard, or Veld Paraw, in the heath. 
When the land is clothed with vegetation, this erosion of the soil is prevented, and a large percentage of the water is retained and absorbed by the earth. Here, again, we have cause and effect. Man destroys the birds ; insect pests increase and eat up the vegetation ; pasturage disappears and the land is ruined. These are the two sides of the picture :-No birds : swarms of insects; no food for stock; barren land. Numerous birds : few insects ; rich pasturage ; good land, increasing every year in fertility. Verily, as ye sow, that shall ye also reap.

In the vicinity of Pietermaritzburg, many years ago, the larks and other grass birds were practically exterminated by youths and boys with shot and pellet guns. This resulted in the grass being eaten off most alarmingly by grasshoppers. The tender, sweet and nutritious grasses died off and the hardy wire grass, which is unpalatable to stock, superseded it. In other places noxious weeds, which the grasshoppers would not eat, gained the upper hand. ripened their seeds and sowed them broadcast, with the aid of the wind, over the cultivated lands. Thus, owing to our carelessness and want of specialised knowledge, or criminal failure to heed the warnings of naturalists, dire and lasting harm was wrought.

James Buckland mentions an instance which occurred some years ago in Bridgewater, Massachusetts, U.S.A. A great battue was held by the ignorant townspeople in the spring-time, resulting in so many grass birds being killed that their dead bodies were ploughed into the land for manure. The people paid dearly for 
their brutality, for the following year the grass was attacked below ground and above ground by insect pests in such numbers that it withered and died as if blasted by fire.

The wanton destruction of wild birds in one of the inland districts of Australia, on which large numbers of settlers had established themselves with the helping hand of Government some years ago, brought its punishment swift and sure. Caterpillars and beetles swarmed over the land and succeeded in converting wide areas of magnificent pasture land into a barren waste. The grasses were utterly destroyed owing to the roots having been devoured.

A similar calamity befell the New Zealand farmers. The senseless and brutal persecution of native birds resulted in a plague of crane flies and click beetles. The larvæ of these pests attacked the roots of the rich meadow grasses, and killed the plants as effectually as though they had been scorched by heat. 'This scourge threatened to spread over the length and breadth of the land. Again man availed himself of the aid of his persecuted feathered friends. The English starling was introduced. It multiplied rapidly and fed greedily on the larvæ, and saved those undeserving farmers from having to pay the extreme penalty for their misdeeds.

Without the help of our bird allies there would be no pasture lands for stock. Every blade of grass would disappear from the face of this green earth. The cut-worms, grasshoppers, caterpillars, and grubs would make short work of it, roots and all.

Man would be as powerless in the face of this VOL. I. 
mighty host as a child in his efforts to stem the advance of an avalanche. Without the help of birds man would quickly perish, and Earth would know him no more. Yet this vital truth is not taught to school children. They go forth from the schools and, knowing no better, great numbers of them employ much of their time in setting back the clock of human progress and expansion.
"I saw with open eyes
Singing birds sweet,
Sold in the shops
For people to eat ;
Sold in the shops of
Stupidity Street.
"I saw in vision
The worm in the wheat,
And in the shops nothing
For people to eat ;
Nothing for sale in
Stupidity Street."

\section{Ralph Hodgson.}

Partridges are magnificent conservators of pasture lands. When overabundant in the vicinity of cultivated lands, partridges are apt to do a certain amount of damage. If the farmer, after due consideration, considers they are doing more harm than good, he can easily reduce their numbers. He should bear in mind, however, that they are warring all the time on insect pests, and that if these insects were allowed to breed unchecked by the partridges, they would very likely do his crop 50 per cent. more damage than the birds. Insects may be compared to weeds in a garden. If 


\section{BIRDS AND PASTURACEF}

weeds are not systematically destroyed, the entire garden will soon be overrun with them, and the useful products choked. So, too, with insects. Kill off their natural enemies, and they multiply and spread with even greater rapidity than weeds, until they cover the entire farm, bringing red ruin to the owner.

The desirability of careful investigation by trained men into the value or otherwise of birds is brought home by the fact that the Legislature of Pennsylvania, on 23 rd June I 885 , passed an Act known as the "scalp Act," for the destruction of hawks, owls, weasels, and minks, providing a bounty of fifty cents each. This Act was passed after a great outcry and much pressure by farmers, and it was fondly hoped that agriculture would benefit wonderfully.

The law was in operation eighteen months, and in that period of time 90,000 dollars were paid out in bounties. Experts subsequently went thoroughly into the matter and estimated the total annual loss to poultry in the State of Pennsylvania to be about I,2 50 from the depredations of the birds and animals outlawed. It was calculated that every hawk, owl, and weasel killed about 900 rats and mice annually. The result of the operation of this Act for the one and a half years of its existence was the destruction of I 28,57I of the most inveterate enemies of rats and mice. The experts put down the total loss to agriculture for this short period of the reign of stupidity and ignorance at 3,947, I 30 dollars, or, to put it in another way, the State threw away 2,105 dollars for every dollar saved. This only represented the direct 
loss during the operation of the Act. The destruction of so great a number of enemies of rats and mice enabled the latter to multiply until, by slow degrees, the balance of Nature was restored.

The ultimate loss to the State by this deplorable interference with the workings of Nature must have resulted in the loss of at least 50,000,000 dollars. The destruction of so-called game birds to-day is a practice which brings financial loss on a very large scale. The partridge is an example. At intervals during the game season, which is during the winter months in South Africa, I examined the contents of a large number of crops, and they consisted of termites, beetles, grasshoppers, locusts, slugs, snails, larvæ of a wide assortment of insects; nodules from the roots of water grasses ; seeds, and the fleshy roots of weeds, and those of a few small veld plants.

The contents of stomachs which I examined at intervals during the summer months consisted of the same miscellaneous collection, with the addition of a large number of caterpillars, eggs of locusts, winged termites, grass and weed seeds.

"The summer came, and all the birds were dead;

The days were like hot coals; the very ground Was burned to ashes; and in the orchards fed

Myriads of caterpillars, and around

The cultivated fields and garden beds

Hosts of devouring insects crawled, and found

No foe to check their march till they had made

The land a desert without leaf or shade."

LONGFELLOW. 


\section{BIRDS AND FORESTS}

'THE forest trees have many enemies. The insect is by far the most formidable. Remove Nature's checks on the multiplication and spread of insect life for a few years, and the forests would be swept out of existence.

Like a human army the insect host is divided up into regiments and battalions, and their methods of attack differ one from another. Each has its special allotted task to perform. Some of them attack and devour the seeds and nuts; others eat up the roots of seedlings. Another kind deposits eggs in a crevice in the bark of a tree. These

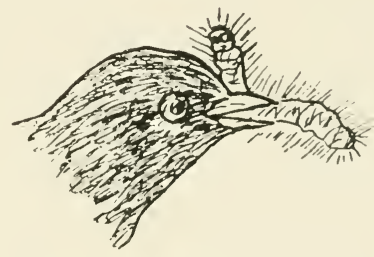

The Cuckoo and the Oriole are fond of hairy caterpillars. hatch into grubs, which bore their way into the trunk or branch and feed upon its substance. The holes let in moisture and destructive fungi which gradually bring about the death of the tree by slowly but surely sapping its life, like a cancer in the human body. The rotting eventually becomes so extreme that the tree dies, slain indirectly by the grub of a beetle.

Other kinds of grubs attack and feed on the soft inner bark and sap. Caterpillars swarm over the entire tree and denude it of leaves. 'The leaves are the breathing organs of trees; they are its lungs by means of which the tree inhales carbonic acid gas and 
exhales oxygen. The majority of trees die if deprived of all their leaves. I have seen patches of forest blasted and dry as though stricken by a fierce wave of heat. I watched an army of caterpillars kill a noble old oak tree in Pietermaritzburg. They began at the top of the tree and, eating many times their own weight of leaves each day, they, in the course of two weeks, stripped it absolutely bare of foliage. Then, descending to the ground in the night, they migrated to another tree and blasted it also. A few birds made daily assaults on this mighty host, but alas! they were but the attenuated remnant of a once strong army of defence. The human folk in their blindness had succeeded in almost exterminating their allies.

Battalions of gall-flies attack the twigs and form galls upon them. Weevils bore into the pith and lay eggs which hatch into grubs. The cicada, or "Christmas bee," inflicts wounds in trees, often of a serious nature. Aphides, scale insects, and plant lice weaken the tree by sucking its juices, which are to it what blood is to us. The grubs of great numbers of species of moths feed upon the buds and flowers. Preyed upon by such hosts of enemies, the tree grows increasingly weak and becomes a prey to parasitic plant growths such as fungi; and the terrible white ant or termite attacks both roots and trunk of the harassed and sickly giant.

Such are the enemies which prey upon forest trees; enemies which, if not kept sternly in check, would multiply in an incredibly short while and sweep the forests out of existence. And without 


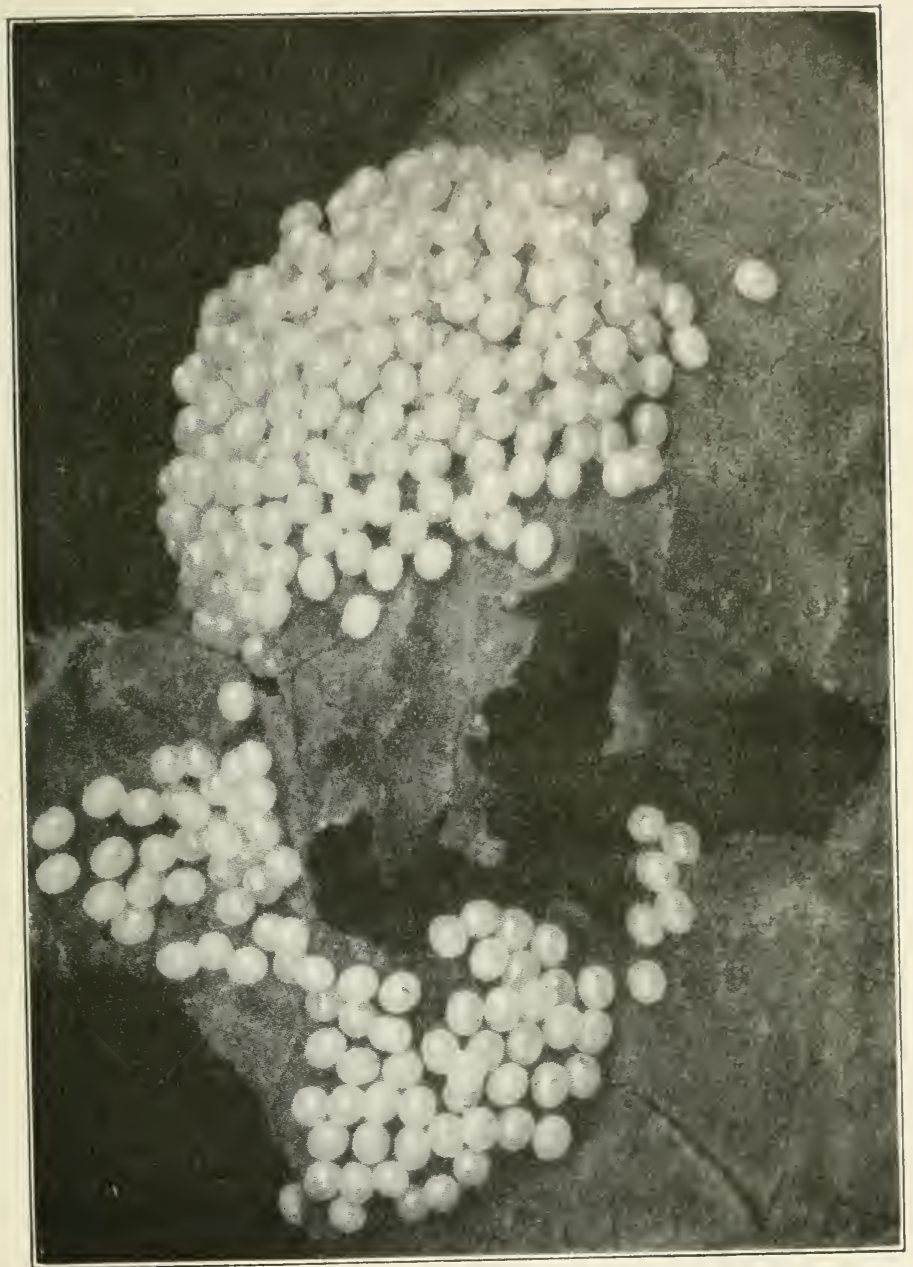

Eggs of a moth on a leaf.

Small birds diligently search the foliage of trees, shrubs, and the farmers' crops for the eggs of insects on which they greedily feed. (Photo by Y. K. Roots, in the National Geographic Magazine of Anerica.) 
forests all higher forms of life in the world would perish.

Buckland puts it very aptly: "But for the trees, the insects would perish; and but for the insects, the birds would perish; and but for the birds, the trees would perish."

Nature fortunately has provided an efficient army to keep the enemies of the forest trees in check. They breed too rapidly, and they are too clever in hiding and otherwise escaping notice for birds ever to absolutely exterminate them. But so long as man does not unreasonably persecute the birds, they will succeed in keeping the enemy in check so that the damage inflicted may be easily made good. Purely insectivorous birds will never increase too largely in numbers except for a brief space, for an excess of insect-eating birds means a scarcity of food, and the less physically fit die off, and so Nature adjusts the balance.

What of the many fruit-eating birds in the forests? Do they cause damage? By no means. They are one of Nature's tree and shrub planters. Eating the berries and fruit, they sow the seed far and wide. At Port Elizabeth the sand dunes at one time threatened to overwhelm the southern portion of the city. Port Jackson wattles (Acacia cyclopea) were planted over the dunes. What was formerly a vast shifting waste of sea sand is now covered with a dense forest of these trees. The wattled starling, commonly known as the locust bird or klein springhaan vogel (Creatophora carunculatus), is very fond of the red, fleshy appendage 


\section{BIRISS AND FORESTS}

of the hard, black seed of this wattle tree. In eating it the bird usually swallows the seed as well, and this passes unchanged through its intestines, and is voided. These starlings spread themselves in flocks over the veld and hill-sides in search of grasshoppers, leaf and root destroying insects, with the result that the acacia trees are springing into existence in the most unexpected places. If, for instance, the trees were allowed to grow unchecked for a few centuries a mighty forest would be the result. The local forester was puzzled to account for the presence of wattles which sprang up and flourished along the wire fences. The wattled starlings perch in thousands on these fences and void the seeds. Wherever these starlings are in the habit of congregating, masses of trees soon come into existence.

A tree establishes itself perhaps owing to a seed which has passed through or been cast up from the crop of some fruit-eating bird. It grows to maturity, sheds its seeds, and its children grow up around it. Birds feed upon the berries or fruit, and drop the seed wider afield. Scores of isolated clumps of trees come into being. The sowing of the seed by birds, wind, and animals proceeds, and a great forest is the ultimate result.

Our feathered guardians of the forest perform their duties well and faithfully. The woodpecker is Nature's policeman of the tree trunks and branches. Insects attack a tree and enter it ; fungi follow, and decay sets in. The woodpecker attacks the dead or dying wood and clears it out as neatly as a surgeon removes a 
dangerous tumour or cancer, and the tree heals up the wounds and the danger is overcome. Woodpeckers rarely attack sound wood. When making a home in a tree trunk to rear a family, the bird usually attacks a decayed spot and indirectly does the tree a valuable service by removing the fungoid growth and dead

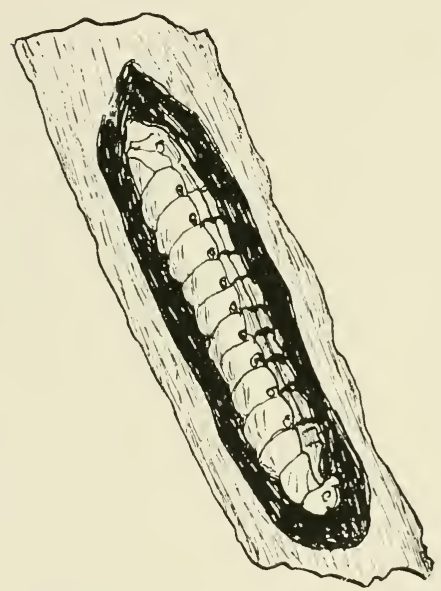

The Woodpecker eats the worm in the wood. wood, which gives the cells of the tree an opportunity to form a shield of woody tissue against further attacks by fungi.

The woodpecker possesses feet and claws specially adapted for climbing up, down, and round about the tree trunks and branches. The stiff tail acts as a support when the bird is at work pecking out decayed wood, or removing dead bark in search

of insects, their eggs, and grubs. Insects have a terrible time when these feathered policemen of the woods are plentiful. Those insects which bore into and breed in timber are practically immune from the attacks of other kinds of birds, and but for the onslaughts of the woodpeckers the wood-boring insects, which eat twice their own weight of wood each day, would multiply and ruin the forests and invade our orchards and gardens. 


\section{BIRDS AND FORESTS}

These birds know their business, and they perform it to perfection. Every inch of the bark is inspected for traces of the presence of insects. A slight groove, a trace of gnawed wood, a tiny hole in the bark, afford clues which are energetically followed up. Meanwhile

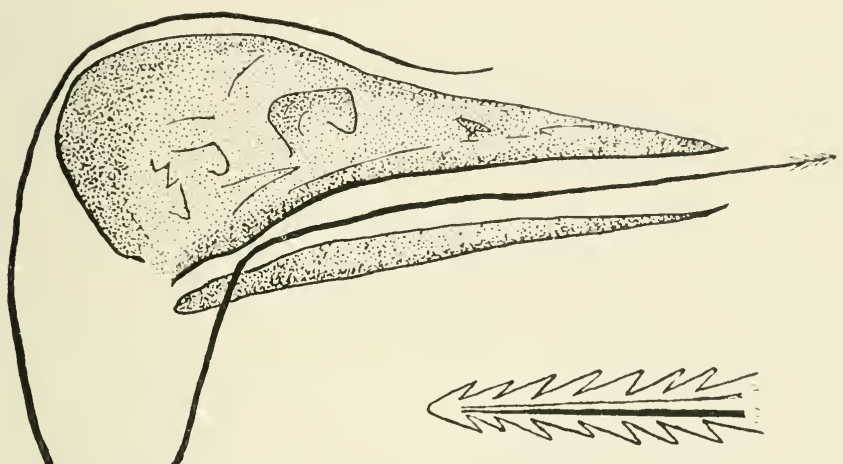

The tip of a Woodpecker's tongue.

The tongue of the Woodpecker is round and worm-like. It curres round the base of the skull and over the top. It can be extended for some distance from the end of the bill. It is covered with a sticky mucus, to which insects adhere. Its tip is pointed and barbed. This wonderful tongue is used for picking insects from leaves, twigs, and bark. Also for penetrating the long winding tunnels of wood-boring larvix. The tip of the tongue is driven into the body of the grub, and the barbs prevent the viction from escaping.

the bird is continually tapping the tree with its beak, and so acutely attuned is its sense of hearing that it knows instantly whether the wood is sound or in a condition of decay. If the latter, it rips off the bark, pecks away the decayed wood, and greedily swallows the borer grubs which have caused the mischief. 'The cause being removed, the tree recovers. 
In the Tzitzikama and Knysna forests the grub of a longicorn beetle does considerable mischief. The grubs bore into the hardest wood and utterly ruin it for timber purposes. These large borer grubs feed upon the wood until mature. When adult the grub bores its way to the surface and changes into a chrysalis, leaving a veneer of bark between its head and the outer world. After a period it emerges as a large winged beetle. The woodpecker is an adept at locating these chrysalides and, tearing off the protecting bark, they are triumphantly drawn out and swallowed by the bird or fed to her brood.

For twenty years I made a special study of birds in their native haunts, mostly in Natal. I lived with them in the fields, valleys, forests, and on the mountain tops, spending days and weeks at a time in the wilds, my sole companions being a pony, dog, and note-book. The stomachs of the different species of South African woodpeckers were examined at various times, and noted. The contents averaged about 70 per cent. beetles and their larvæ. The great majority of these were wood borers; others were destroyers of roots, leaves, buds, berries, and fruits. An average of 30 per cent. consisted of white ants (termites), caterpillars, moths, and various species of leafdestroying insects. Never a trace of seed, berry, or fruit did I ever discover in the stomach of a woodpecker.

Sound wood has no attraction for a woodpecker, for there are no insects there. The bird is out for food and not to expend its strength in useless labour. It 


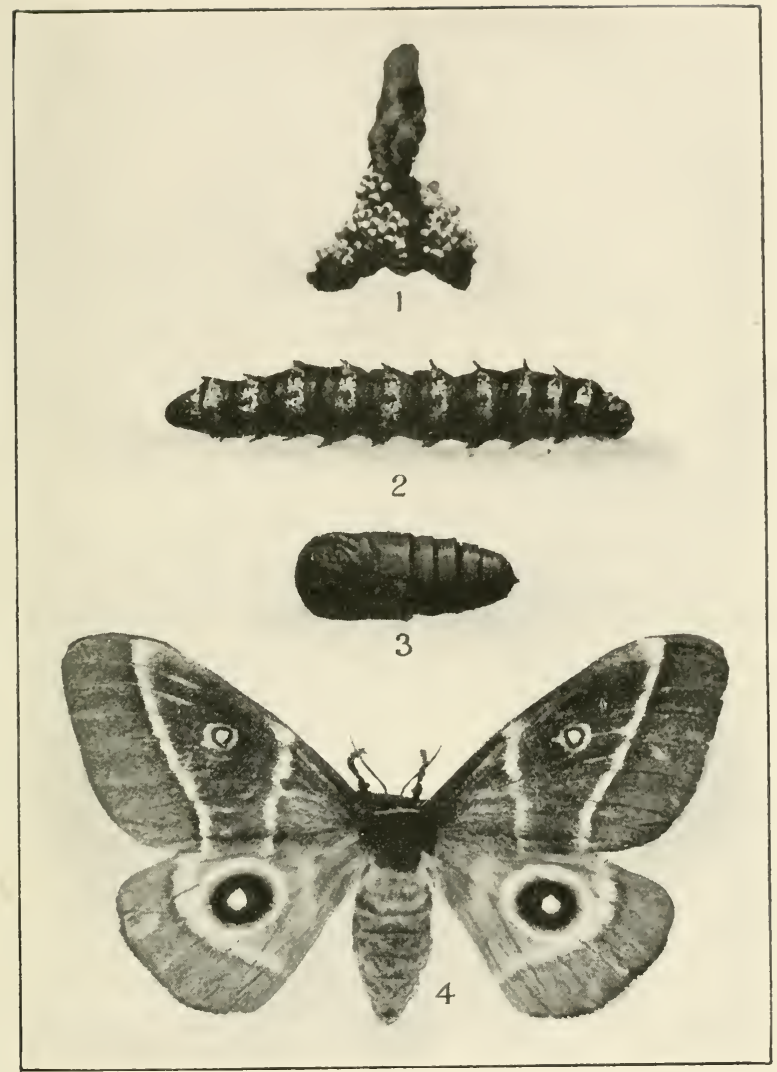

Life-history of a Moth (Nudaurelia isis) which is a pest of apricot, plum, and plane trees.

1. Cluster of Eggs on a twig.

2. Larva or Caterpillar.

3. Chrysalis or Pupa.

4. Adult, or Imago Insect, which emerges from the chrysalis.

This is typical of the life history of all moths and buttertlies, viz., egg, caterpillar, chrysalis, moth, or hutterfly. 


\section{NATURAI, HISTORY OF SOU'TH AFRICA}

pecks the rotten wood or removes pieces of dead bark to catch and devour the enemies of the trees; it, in fact, attacks them in their strongholds.

Woodpeckers, with the exception of the three species of American sapsuckers, are eminently beneficial to forestry, and deserve every possible encouragement

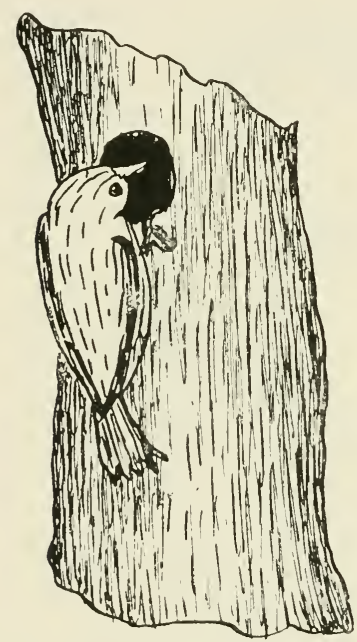

The Woodpecker rears her children in a hole in a rotten tree. and protection, therefore let no man raise his hand against a woodpecker. It is a bird which works in the interest of man all its waking hours, and asks no payment, not even a seed or a fruit. Yes, it is a slave indeed to man, but a willing slave, glad and happy to serve him. Man rewards it by shooting it down. His boys are allowed to make collections of its eggs, and the Kafir umfaans roast the nestlings and eat them.

Man in his folly and ignorance has, in the past, imagined he could dispense with the services of the bird. Every time he made the experiment he failed miserably. With his costly pumps, his sprays, poison baits, and nets, the extent of his achievements are the saving of a limited number of trees.

Man values lightly that which he gets for nothing 


\section{BIRDS AND FORESTS}

-it was ever so. The forest birds, which keep the ravening hordes of insects in check in order that he and his kind might multiply and overspread the earth, are often mercilessly murdered for the despicable and savage purpose of adorning a woman's hat. Aye ! woman's vanity in this respect has cost the peoples of the world countless millions of money, and retarded the expansion of the human race and the opening up of new lands to an alarming degree. Yet our educationists stand aloof when there is such a crying need for bringing enlightenment to the school children on this vastly important matter. There is no time, they say, for extra subjects to be taught. Children are already weighted down sufficiently with lessons. Yes, they leave school freighted with much so-called knowledge which is of little or no value to the vast majority of them in their struggle for existence. Poor, indeed, is their equipment for the grim struggle for existence which is before them. We simply blunder along-muddle through anyhow. Inquire of librarians of public libraries and they, one and all, will inform you that for one book of fact taken out by subscribers, five hundred books of fiction are read. This apathy and distaste for knowledge shown by the average adult is a clinching reason why knowledge of a practical kind should be taught to school children.

The pond in which a frog dwells is the whole world to him, and so it is with the majority of human folk. They are shut up in a prison of their own makingthe doors are unbarred, but they seek not to open them. Seek and ye shall find. 
"A primrose by a river's brim,

A yellow primrose was to him,

And it was nothing more."

A wild bird's feather in a woman's hat is an ornament to her and those who behold it, and nothing more. To the ornithologist it is something more.

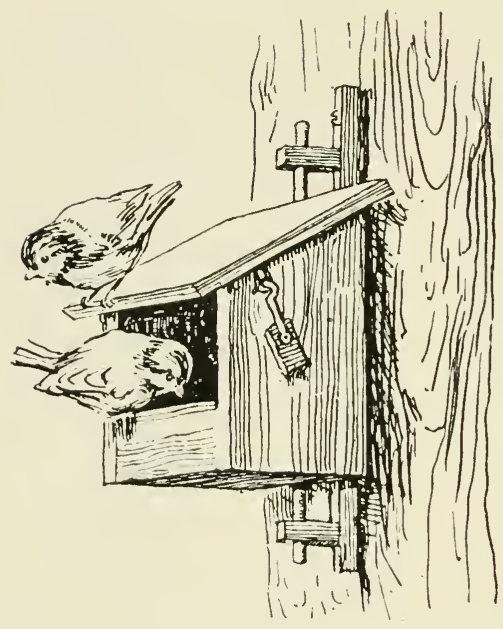

If you want birds in your neighbourhood, encourage them to breed by providing Nesting Boxes. -He, in vision, sees a lovely pair of innocent birds chirping, singing, and frolicking in an excess of happiness while they busily build their home. He sees the mother bird brooding lovingly over her cherished eggs, while her mate sits on a twig near by and makes her vigil a joy indeed with his sweet song and loving presence. Ever and anon he takes his turn on the eggs, so that she may go forth for exercise and search the forest for insects to satisfy her hunger. Then the young birdies come, and the joy of that loving couple knows no bounds. From dawn to dewy eve they scour the forest and fields for insects to satisfy the voracious appetites of their children. While engaged in this loving service to his children the father falls, riddled 


\section{BIRDS AND FORESTS}

with shot or a lead pellet in his heart, murdered for no worthier purpose than that his plumage may put a few pence into some human brute's pocket, and ultimately adorn a woman's hat.

What of the widowed mate and the orphan children? She, as a general rule, dies of a broken heart, and the babies perish miserably of starvation and cold.

Aye ! truly through lack of the right kind of knowledge we do the most diabolically cruel things. Ignorance and cruelty go hand in hand surely. People, as a general rule, are not by nature cruel-it is ignorance, superstition, and erroneous beliefs which make them so.

In I 905 the larch plantations on estates surrounding Bassenthwaite Lake were seriously affected by the pest known as the large larch saw-fly. On one estate alone several thousand trees were destroyed. In 1907 a severe outbreak of the disease was observed on the Thirlmere plantation of the Manchester Corporation. It was pointed out that various species of birds destroy this pest, and accordingly 60 nesting boxes were hung in the trees as an experiment. Another I I 4 boxes were added in the following year, and 105 more in I 909. The numbers of tits, robins, and starlings increased considerably, and their young were diligently fed on the larvæ of the saw-fly and long-horned beetle. The lower slopes of Helvellyn and the hill-sides on the opposite side of the lake, which a few years before were bleak and barren, were soon covered with young forest trees which resounded with the songs of birds.

$$
\text { VOL. I. }
$$




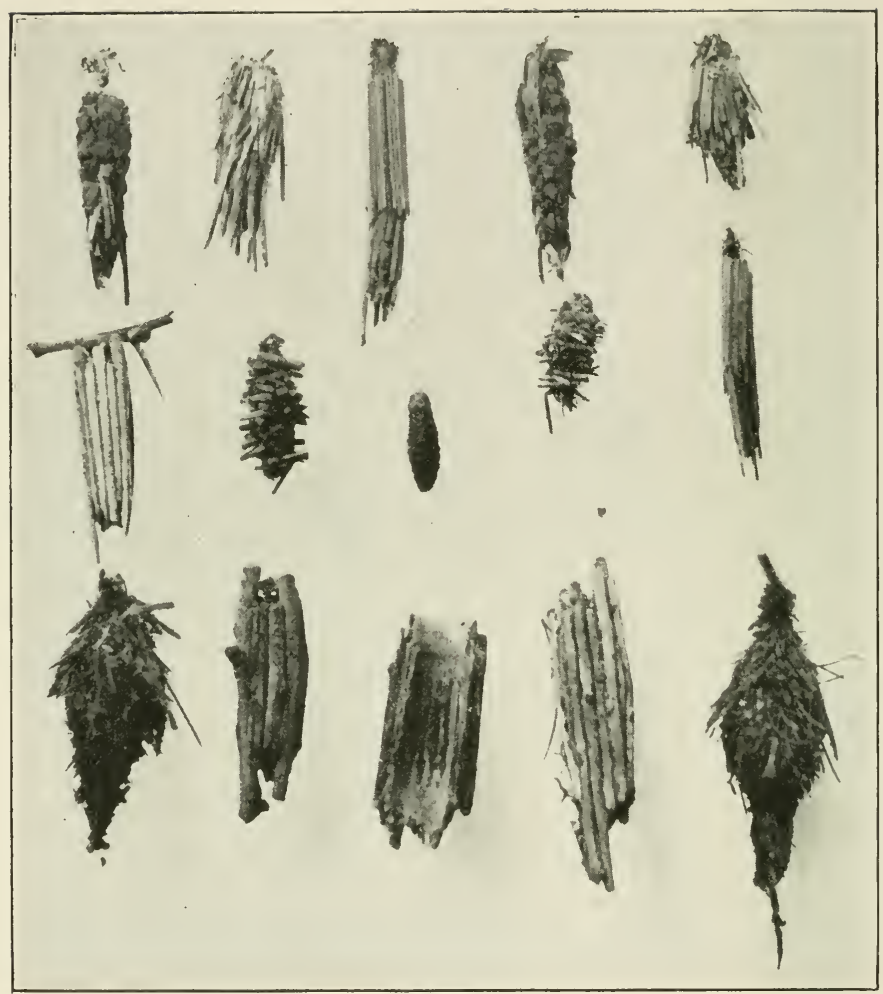

The Bagworm is the caterpillar of a moth. It lives in a silken bag covered with lengths of straw sticks and even pebbles. The Bagworm does immense damage in wattle plantations, and devours many other forms of vegetation. It has become a serious menace to the progress of South Africa.

Birds are the chicf enemies of this pest. They prey on it in the young stage; certain species of birds draw out the caterpillar from its bag, while others feed on the moth. 


\section{BIRDS AND FORESTS}

Those who are practically connected with the business of forestry are keenly aware of the great good to arboriculture done by the woodpeckers. As the rooks, partridges, and starlings are the recognised guardians of pasturage and cattle lands, so woodpeckers are the custodians and caretakers of forest growth.

If landowners, more particularly owners of woods, only knew and considered the great value of woodpeckers and their allies in continually cleansing their trees and freeing them from all vermin, they would not be satisfied until they had the feathered friends of their trees adequately protected, as is now being done in the United States. Wood, free from insects, is practically indestructible.

Birds are the most powerful insect destroyers we have. In the best forests, and particularly those which have been specially planted, there is very little natural provision for the nesting of birds. This should be provided in the shape of nesting boxes of kinds suited to the needs of the species of birds which prey on treedestroying pests. Unless this is done, plantations will continue to be ravaged owing to the limited number of birds which will be able to make their homes there. If suitable numbers of nesting boxes are affixed high up on the trees in various parts of the plantation, the birds will very soon find them out and utilise them.

These measures have been employed with unqualified success in controlling the destructiveness of insects in woods in certain parts of Europe and America. The Hainich Wood, for instance, south of Eisenach, in Germany, which is several miles in extent, 
was stripped absolutely bare by the caterpillars of a small moth (Tortix viridana) in the spring of 1905 . The neighbouring wood belonging to Baron von Berlepsch was untouched. In this wood some years previously over 2,000 nesting boxes had been affixed to the trees. Dr Gordon Hewitt, D.Sc., in writing on the subject, says: "It stood out among the remaining woods like a green oasis."

\section{BIRDS AND HEALTH}

BIRDS are a strong factor in checking the onslaughts of the disease microbe army. We now know that the great majority of diseases which attack man and beast are carried by insects. A blood-sucking fly inoculates man with the parasites which cause sleeping sickness. Other blood-sucking flies carry the germs of a number of deadly diseases to stock animals, and inoculate them direct by puncturing the skin with a sharp lancet. The common house fly is one of the foulest of feeders, and gets smothered with the bacteria of various diseases, and also voids them alive from its body. These germs it sows in our households and amongst our domestic animals. The house fly is now regarded as the chief cause of the spread of diseases in human communities and to the various members of households.

The larva of a gad or warble fly produces 


\section{BIRDS AND HEAITH}

tumours under the skin, and in the ear and nostril cavities of animals.

Mosquitoes inoculate man with a parasite which causes malarial and yellow fevers. We strongly suspect it of being one of the agents in the spread of other diseases, both animal and human.

Ticks are the transports which carry a variety of

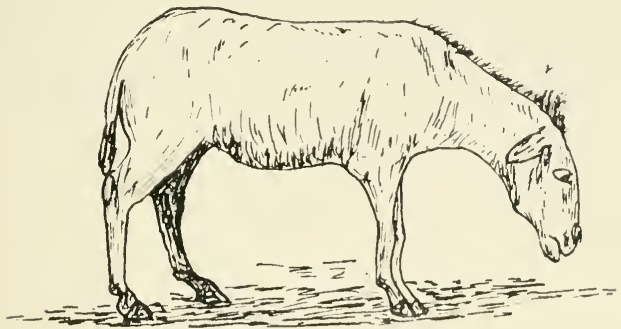

Donkey dying of ngana, or tse-tse fly disease. Blood-sucking flies are the cause of sleeping sickness in man and ngana in animals. They effectively check the spreacl of the human race in Africa. Ground-feeding birds eat the pupre, and fly-catchers and swallows snap up the flies.

terrible diseases to household pets and stock animals. Fresh water snails are the hosts of the liver, fluke, and bilharzia parasite.

A host of species and kinds of birds unknown to the majority of people are waging a relentless warfare on these disease-carrying insects. The maggots and chrysalides are devoured in countless numbers by water fowl, guinea-fowls, partridges, pheasants, quails, larks, plovers, crakes, rails, and dozens of other kinds of birds. The wagtails, fly-catchers, swallows, swifts, thrushes, warblers, sunbirds, bee-eaters, drongos, and 
other birds wage war on mature blood-sucking blow and common house flies.

White eyes, warblers, wrens, sun birds, and many other species hunt the mosquitoes from their lurking

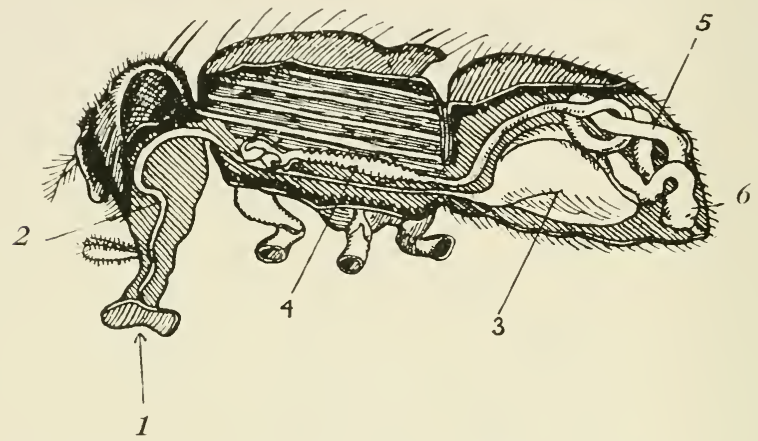

Diagram of the Digestive Organs of the House Fly.

1. The Proboscis or Sucker by which fond is drawn up.

2. The Tube through which food passes to the crop.

3. Crop or Bag in which the food is stored. The fly romits the food, a drop at a time, on whatever it may be sitting on. It is then sucked up a second time and passes into the real stomach, where it is digested.
4. The Stomach.
5. Intestines.
6. The Vent.

Disease microbes pass through the fly's digestive tract and issue forth alive. They cling to the fly's feet and body. Flies, in consequence, are spreacters of diseases. Birds are their enemies.

places amidst the foliage, and feed upon them. The night jar, miscalled a night hawk, attacks them on the wing by night. This bird has a capacious stomach and extremely rapid digestion, and a single bird can account for at least a thousand mosquitoes in a night.

Who has not seen the swallows, martins, and swifts at sundown skimming low over the ground until night 


\section{BIRDS AND HEAI,TH}

sets in? Are they at play? By no means. They are doing battle for us against the hosts of mosquitoes and other night-flying insects which are emerging from their hiding-places.

What of the tick-the scourge and terror of the stock farmer and dairyman? Here, again, the birds render sterling service. The ox-peckers or tick birds are specially evolved for the purpose of removing ticks from large animals, for the nature of their toes

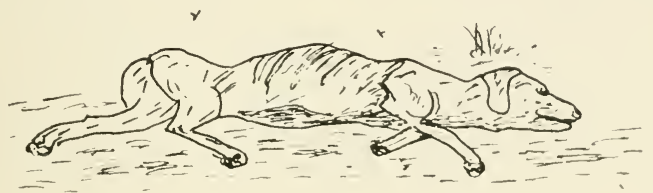

Tse-tse fly disease is fatal to dogs and all stock animals. Guinea-fowls, partridges, pheasants, and thrushes scratch up the pupe of the flies and eat them.

enables them to climb all over their host-down and up its legs, neck, and round its abdomen. Every part of the hide is inspected.

While the animals are lying at rest in the fields, the white egret, with dignified stride, walks round the beast and pecks off the blood-gorged blue female ticks which would, if left alive, have laid thousands of eggs.

The starlings, larks, plovers, crakes, wagtails, and other birds search the ground in the close vicinity for any gorged female ticks which have left their host and are seeking a suitable spot in which to lay their eggs. 
Out in the fields the partridge, plover, lark, and other ground birds peck the ticks from the grass stems.

Thus by waging incessant war on the insects which carry disease microbes to man and beast, the bird is rendering a service which cannot be overestimated. Should a few of them, when driven by hunger, take a little grain, is it robbery? Have we the moral right to brand them as impudent thieves, and cry aloud for their extermination? If it were not for the services of the bird in catching and destroying disease-producing insects, man would make no headway. It is questionable whether he could even manage to exist, except in a miserable way and in very limited numbers.

The United States Government, on the accession of $\mathrm{Mr}$ Wilson as President, issued an order forbidding, under heavy penalties, the destruction of any wild bird in the Panama Canal zone. This was real Solomonic wisdom, and it makes one wish other governmental bodies were as wide awake in their efforts to reduce the ravages of diseases.

Bilharzia is a terrible scourge of the human race in Africa, Southern Asia, and even South America. It is caused by a circaria worm of microscopic size which lives in fresh water streams, ponds, and marshes. It enters the body usually when bathing, through the human skin and the mucous membranes of the mouth and throat, and produces an incurable disease. It has been ascertained that snails and other fresh water molluscs, crustaceans, and the water-dwelling larvæ of various winged insects act as intermediary hosts 


\section{BIRLS AND HEAI.TH}

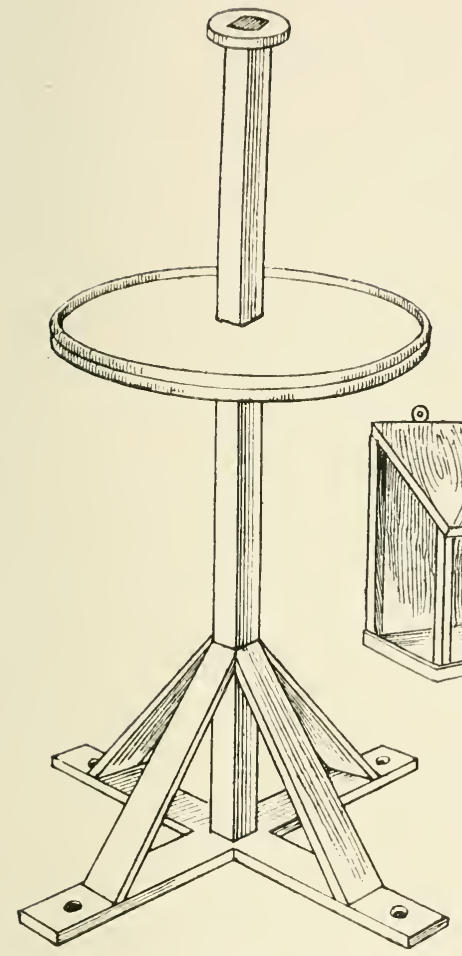

No. 3 .
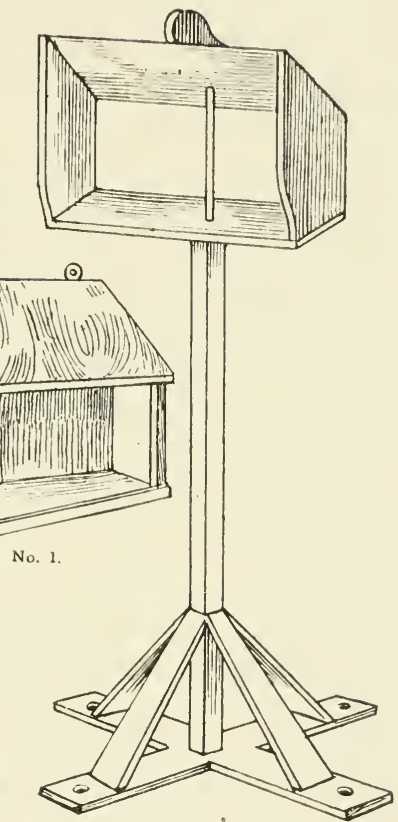

No. 2.

No. 1.-A bird shelter with open front and sides to hang on wall.

No. 2.-A bird shelter and feeding box. Swings with the wind. Glass at back. For garden or balcony.

No. 3.-Open feeding tray. A nesting box can be fixed to the top. For garden or balcony. 
for this circaria worm. Should the eggs enter the water from the urine or fæces of an infected person or animal, they quickly hatch, and the larvæ attack and enter the bodies of these hosts. Here they complete their cycle of development, and when mature leave their lowly host and emerge into the water. Unless able to enter the body of a human being or some other warm-blooded animal, they perish in about thirty-seven hours. So here, once again, we have a valuable ally in the bird. To reduce or eradicate the disease, the intermediary hosts of the worm must be attacked and destroyed. Large numbers of species of birds feed greedily upon fresh water molluscs and other forms of aquatic life. Others devour the winged insects which pass the larval period of their lives in water. In our struggle against this terrible scourge which is prematurely killing off or making physical wrecks of thousands of people, the water-frequenting birds are our greatest allies.

The microscope reveals the alarming fact that the germs of that terrible disease, sleeping sickness, breed in practically all the larger wild animals. They are immune to sleeping sickness; but a blood-sucking fly carries the germs from these to both natives and Europeans. The disease has swept off the human populations of entire districts, and it is threatening to make tropical Africa unfit for human habitation. It may be necessary to kill the wild animals, but they are not really guilty. True, they unconsciously carry the germs in their blood, but the arch-criminals are the women who wear the plumes of wild birds in their 


\section{BIRDS ANI) HF,AITH}

hats, and the men who kill game birds. 'The birds feed on the larva of the blood-sucking fly, and when they are persecuted and killed, the fly multiplies and spreads sleeping sickness far and wide. A terrible price surely to pay for vanity, so-called sport, and the pleasure of feasting on the bodies of our feathered allies.

When a man is murdered in our midst, we demand that the murderer be punished. Yet we are indirectly killing thousands of people by our selfishness and indifference. Men and domestic animals are dying annually in multitudes from preventable diseases, and we heed not. Men of science are poorly paid, discouraged, and a deaf ear is often turned to their grave warnings and expert advice, except when the knowledge can be utilised for selfish individual financial gain.

"And so the dreadful massacre began ;

O'er fields and orchards, and o'er woodland crests

The ceaseless fusillade of terror ran ;

Dead fell the birds, with bloodstains on their breasts,

Or wounded, crept away from sight of man,

While the young died of famine in their nests:

A slaughter to be told in groans, not words,

The very St Bartholomew of birds!"

LONGFELLOW. 


\section{NATURAL HISTORY OF SOUTH AFRICA}

\section{BIRDS AND WEEDS}

"By the sweat of thy brow thou shalt earn thy daily bread."

This is as it should be, for Nature has no use for those who neither work with their brain nor their hands. The ignorant boor works like an ox to produce a small return. The intelligent man avails himself of all manner of things to lighten his labours, and to enable him to get the largest possible return for his energy.

The time, energy, and money dissipated in warring against weeds are vast. Out in the wilds, weeds serve good and useful purposes, but in cultivated lands they are a pest; and, should we relax our onslaughts, they overspread our lands and crowd out the crops. To prevent the choking to death of the produce of our fields, we are obliged to constantly attack the weeds with harrows, hoes, sickles, and ploughs. The labour is never-ending, for the land is full of weed seeds which retain their vitality for years. It is impossible completely to free cultivated lands from weeds even by constantly destroying them before they mature their seed.

Weeds have evolved a protection against such a contingency. Every plant struggles as purposefully and as intelligently to safeguard its species against extinction as does any form of animal life, including man.

Many kinds of weeds provide their seeds with various ingenious contrivances by which they are 


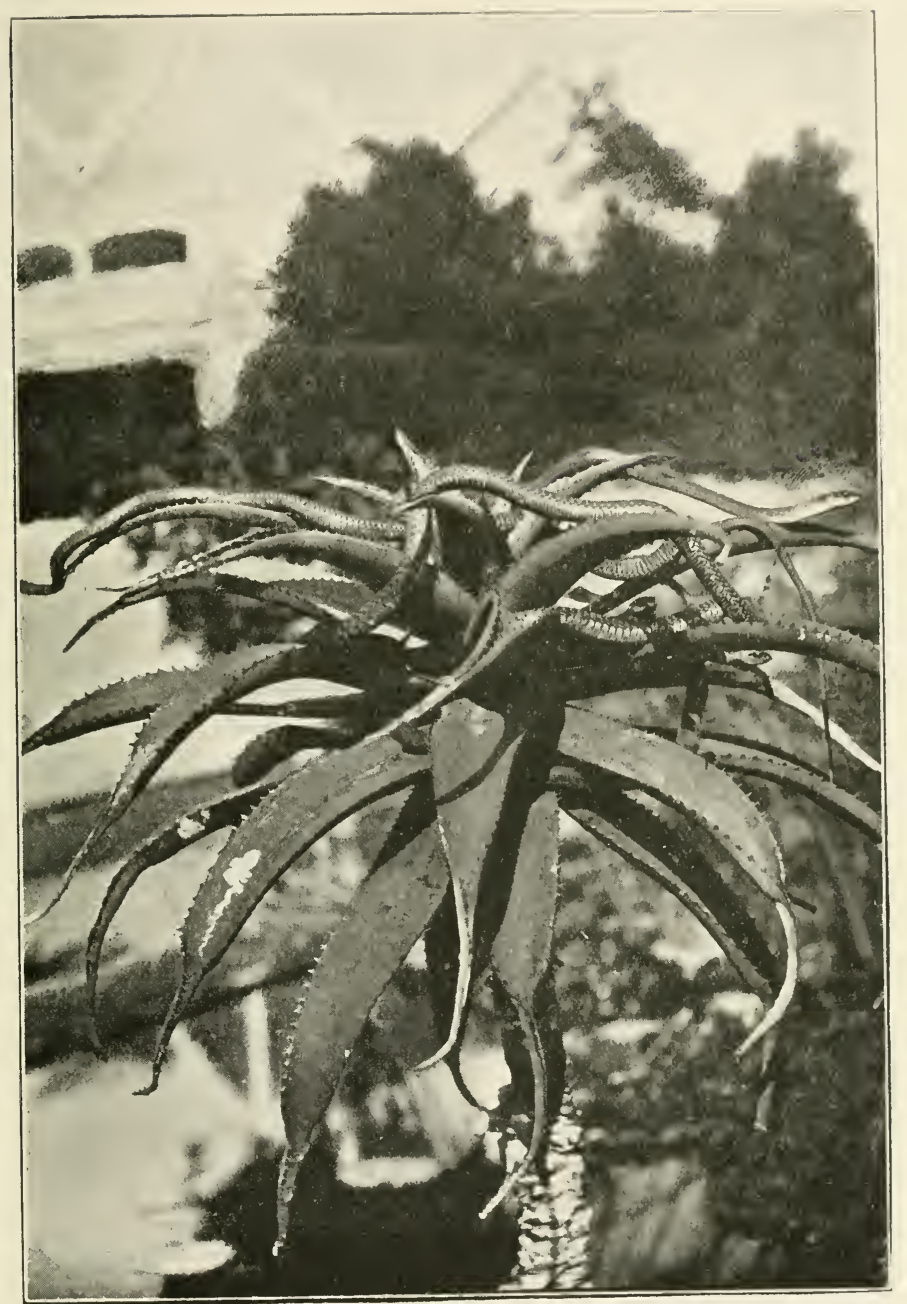

One of Nature's Bird enemies-the Boomslang or Tree Snake (I) ispholidus lypus). Photo from live specimens in the Port Elizabeth Snake Park. 
made so buoyant that even a gentle breeze will waft the seeds away through the air for miles. Others are provided with hooks for catching hold of the hair and wool of animals, and so on.

The farmer by unremitting labour may succeed in keeping his lands comparatively free from weeds, but so long as they are allowed to mature and shed their seed along the fringes of his fields and in his neighbourhood, he will have his lands resown with them.

It would not pay him to attempt to systematically destroy all the weeds on a large farm. Should he try, he and his employees would have little or no time to do anything else.

Nature, however, has not unduly favoured the weed in its struggle for existence. A host of enemies attack it. These are the seed-eating birds. From afar they gather and feed upon the seed when it is reaching maturity. As a general rule, a seed-eating bird makes two good meals a day if undisturbed. Small birds, such as vinks, will eat upwards of an ounce of weed seeds a day. When the seed is ripening it is eaten direct from the weed, and at other times it is sought for upon the ground. Even the much persecuted dove destroys immense quantities of weed seeds. It is very partial to the seeds of the weed commonly known as mistbreedie (Amaranthus paniculatus).

I came upon a young farmer one day lying in a pit. He informed me he was shooting off those pests, the vinks (weaver birds). He had already shot thirty or forty on a portion of a harrowed field which had 


\section{BIRDS AND WEEDS}

already been planted with mealies. I asked permission to open the crops of those he had slain. Every crop contained a variety of weed seeds and larvæ of various insects.

The average quantity of weed seeds consumed by ordinary birds such as weavers, widow birds, and bishop) birds, all of which are popularly termed "vinks," amount to about $25 \mathrm{lbs}$. per bird every year. Doves will eat their own weight of weed seeds every day if the seeds are sufficiently abundant.

The majority of game birds devour immense quantities of weed and water grass seeds, as well as mature bulbs which rob the soil of moisture and plant food, and often seriously reduce the stockfeeding value of land. I have found as many as 4 ounces of weed seeds in the crop of a partridge. The average crop content of one of these birds at midday is $2 \frac{1}{2}$ ounces of seeds of weeds, cut-worms, beetles, grasshoppers, and other insects. Guineafowls perform an immense service in eating weed seeds, locusts, locust eggs, grasshoppers, caterpillars, and larvæ which live underground, and which, in consequence, escape the attentions of the bulk of other species of birds. The guinea-fowl, however, does considerable mischief on newly-sown lands, for it is able to eat $\frac{1}{2} \mathrm{lb}$. of grain at a feed. Out in the wilds, and especially in game preserves, it renders great service in preying upon the larvæ of blood-sucking and other flies, gorged female ticks, etc., and is therefore a factor in checking animal plagues.

Game birds are of great economic value in our 


\section{NATURAL HISTORY OF SOUTH AFRICA}

war against those two hostile armies-the weeds and insects.

These species of birds are of far greater value to a farmer alive and out on his lands, than in the pot.

Of all the game birds the quail is the best weed destroyer. The quail is ranked in the first class among birds which are useful to man. Some authorities consider it is more useful than any other bird. During the spring and summer months it wages a terrible war on insects and their larvæ. With unerring instinct it seeks out their hiding places, and with beak and claws exposes them to view. Morning and evening it is busy hunting these pests in the cultivated fields and pasturage.

Quails feed greedily on insects so long as they are plentiful, and only resort to a diet of grass and weed seeds when insects are scarce. The quail works for the farmer right royally against the insect hordes, from the time the crops are sown in the spring until they are reaped in the autumn. When the fertile male and female termites (white ants) fall to the ground and meet to found a new colony the quail seeks them out and devours them.

As winter approaches insects become increasingly scarce, and the quail then sustains itself almost and often entirely on the seeds of weeds. The seeds of several species of the most rapidly growing and obnoxious weeds are eaten greedily by the quail. This bird breeds during the spring and summer time, and lays from six to a dozen eggs. The chicks are active from birth, like those of the domestic fowl, 
and the number of insects, larvæ, and eggs they destroy in a season is uncountable. Many of the insects preyed upon are of the kinds which pass the larval stage of their lives underground. These grubs do immense damage by eating the roots of cultivated crops, grasses, seedling trees, and shrubs. The majority of species of birds search for insects on the ground, on vegetation, and in the air. The quail takes them both from above ground and underground, and thus renders man a double service. The report of the United States Biological Survey says :-

"It is reasonable to suppose that in the States of Virginia and North Carolina from ist September to 3oth April there were four quails to every square mile of land. The crop of each bird holds half an ounce of seed, and is filled twice a day. Since at each of these two daily meals harmful weed seeds constitute at least half the contents of the crop, half an ounce daily is consumed by each bird. On this basis the total consumption of harmful weed seeds by quails from September to April in Virginia and North Carolina amounts to I, 34 I tons.'

As destructive insects form about one-third of the bird's food from June to August, quails consume 34 I tons of these pests in these States within those two months.

Few, if any, birds other than the quail will eat that terrible pest, the potato bug or colorado beetle. The quail, however, has a special liking for it and eats it greedily, and will abandon all other food so long as plenty of these beetles are obtainable. If for no

VOL. I.

I I 3

8 


\section{NATURAI, HISTORY OF SOUTH AFRICA}

other reason than this the quail should be held sacred.

The fact that the dreaded scourge, the cotton ball weevil, has not annihilated the cotton crops of America and brought red ruin to tens of thousands of people, is largely due to the services rendered by the quail in keeping these insects in check.

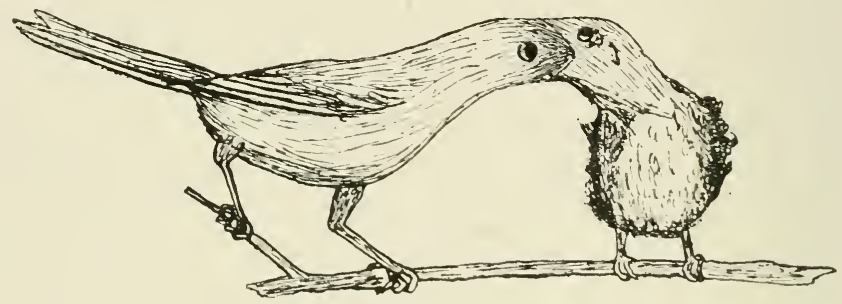

The countryside is diligently searched by the parent birds for Caterpillars to satisfy the voracious appetites of their children. This sketch shows the mother bird in the act of placing a Caterpillar in its youngster's throat.

Here we have a bird which renders man four great services :-

I. It safeguards the vast cotton plantations of the world.

2. It polices the potato crops on which the human race largely depends for food.

3. It wages war on the hordes of insects that attack the crops and pasturage.

4. It helps very largely in keeping noxious weeds in check.

Unlike many other birds, it takes no wages in I I 4 


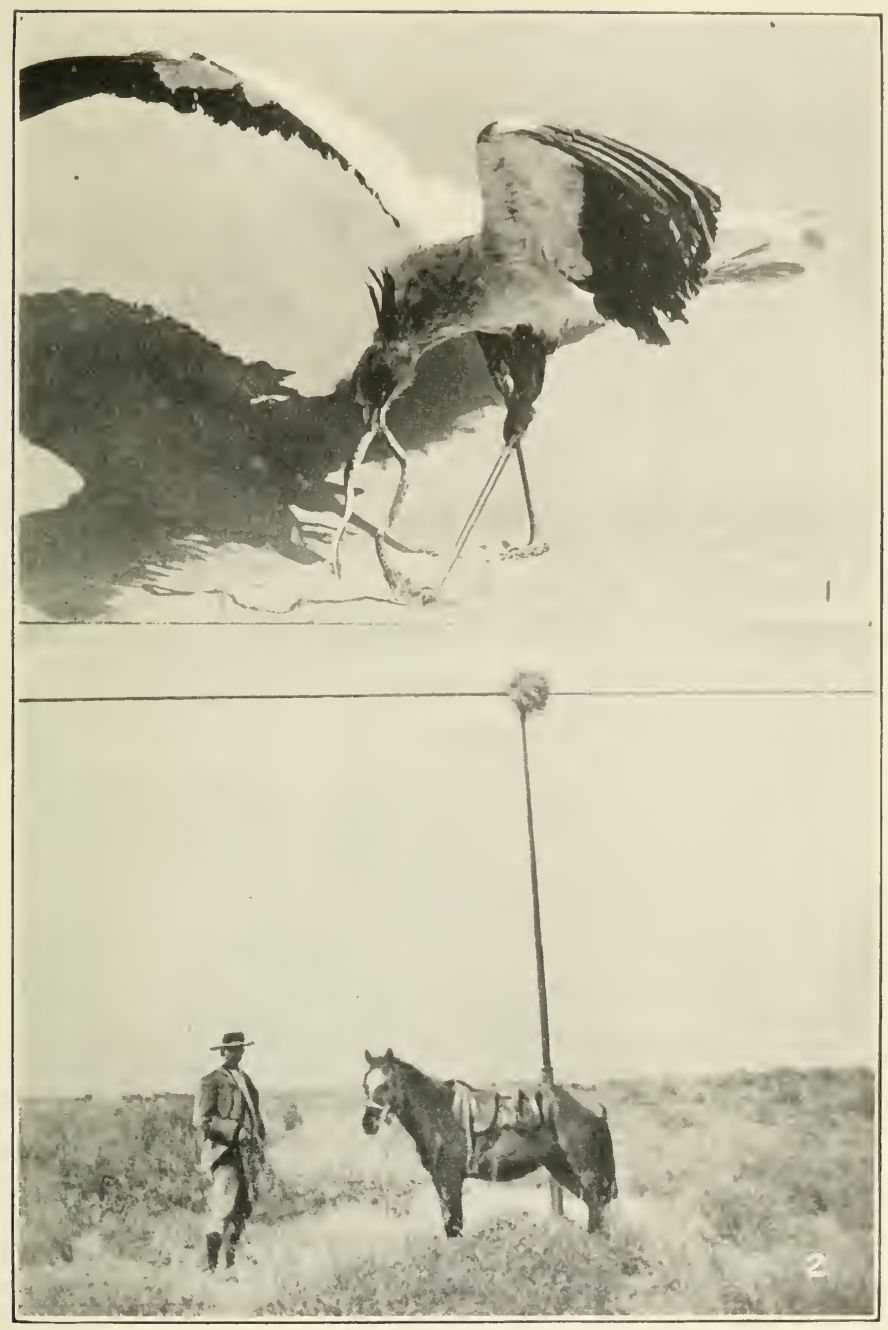

1. Sccretary Bird in the act of killing a snake. When the snake is large and venomous, such as a Cobra, or Puff Adder, the bird employs various tactics.

2. Nest of a Black Crow on the top of a telegraph pole. There is a single wire line between Springfontein and Clanwilliam, and a special man is employed to ride alongside the line to clear the poles of crow's nests which cause short circuiting. (Photo by Sir Frederick Smith.) 
grain or fruit. It works in the interests of man all the time without payment.

Every live quail on a man's land is a valuable asset. Yet, because the little creature has a plump, juicy body, it is mercilessly hunted with dogs and shot down. When will economic Natural History be taught to our children? If other subjects bar the way, then away with some of them and make place for the knowledge every boy and girl should possess. The quail stands in the front rank of birds which should be protected by law. If I were asked to choose a dozen species of birds which I considered served man best, the quail and his first cousin the hemipode or button quail would be two of them.

There are many ways of increasing the productiveness of the land and bringing a greater measure of prosperity to a country, but there is no greater than the conservation of bird life.

I examined the crop of a rook (black crow) which was shot at sundown on a stock farm. There were I 56 wireworms, 32 blue female ticks, and the larvæ of other pests in its crop.

I have stayed at many stock farms at times, and the owners were unanimous that the rook rendered valuable services. They assert it picks up the gorged female ticks which drop from the cattle preparatory to crawling into suitable cover to deposit from 2,000 to 18,000 eggs ; it digs up the larvæ of beetles which prey on the roots of pasture, plants, and grasses; and it devours locusts, grasshoppers, and a variety of other pests which eat the vegetation. 


\section{BIRISS AS SCAVENGERS}

The South African rook is usually seen in pairs, or a family consisting of the parents and the previous season's brood, and each pair have a certain area over which they rule, and they remain in possession unless driven out by another pair of birds. Rooks, however, often assemble on cornfields in numbers and eat a portion of the newly planted or sprouting corn, but it is very doubtful if the quantity of corn they eat counterbalances the destructive insects they devour during the rest of the year. It would be far more profitable for the farmer to employ native boys to patrol his fields during this short period than to poison the rooks.

\section{BIRDS AS SCAVENGERS}

Vultures are the feathered scavengers of Nature. Their mission in life is to eat up the dead bodies of animals which, if allowed to rot away, would poison the atmosphere and sow disease microbes broadcast. The diseased flesh, when swallowed by a vulture, is rapidly digested, and all the harmful bacteria are destroyed by its gastric juices. In the past, before the advent of man into South Africa, the vulture (Alas I 'ogel) and the white-necked raven (Ring-hals) rendered sterling service in keeping disease epidemics in check. When a plague broke out in a herd of antelopes, for instance, the vultures and ravens gathered in thousands, ate up the victims, and left only the bones and splashes 
of blood which the bright South African sun rapidly sterilised. In this way epidemics of disease were checked, and the animals of the country saved from utter destruction.

During the many terrible epidemics of disease which have swept the stock farmers' flocks and herds, the vultures and ravens rendered valuable services in devouring the carcasses with which the veld and hillsides were strewn. That terrible scourge of the stock farmer, gal-lamziekte, has been shown to be due to cattle eating bones with dry, rotten flesh on them, and also to bones of animals whose bodies have decayed. By eating the flesh and picking the bones clean these birds reduce the prevalence of this disease.

Vultures and ravens still do good and useful service, especially in the native territories and northwards right through Africa.

European farmers, however, are rapidly learning how to cope with stock diseases chiefly through the medium of the various farmers' journals, and instead of leaving an animal to rot on the veld and contaminate the grass, it is deeply buried. The Government Veterinary Department is now so efficient that epidemics have little chance of sweeping through the entire country as they used to do in "the good old days," when there was no concerted action taken, and little or nothing was known by farmers about stock diseases and their prevention.

The vulture, owing to the ever-increasing scarcity of carrion, is being forced by hunger to attack lambs and sheep. It is a cowardly bird, and fears an encounter 

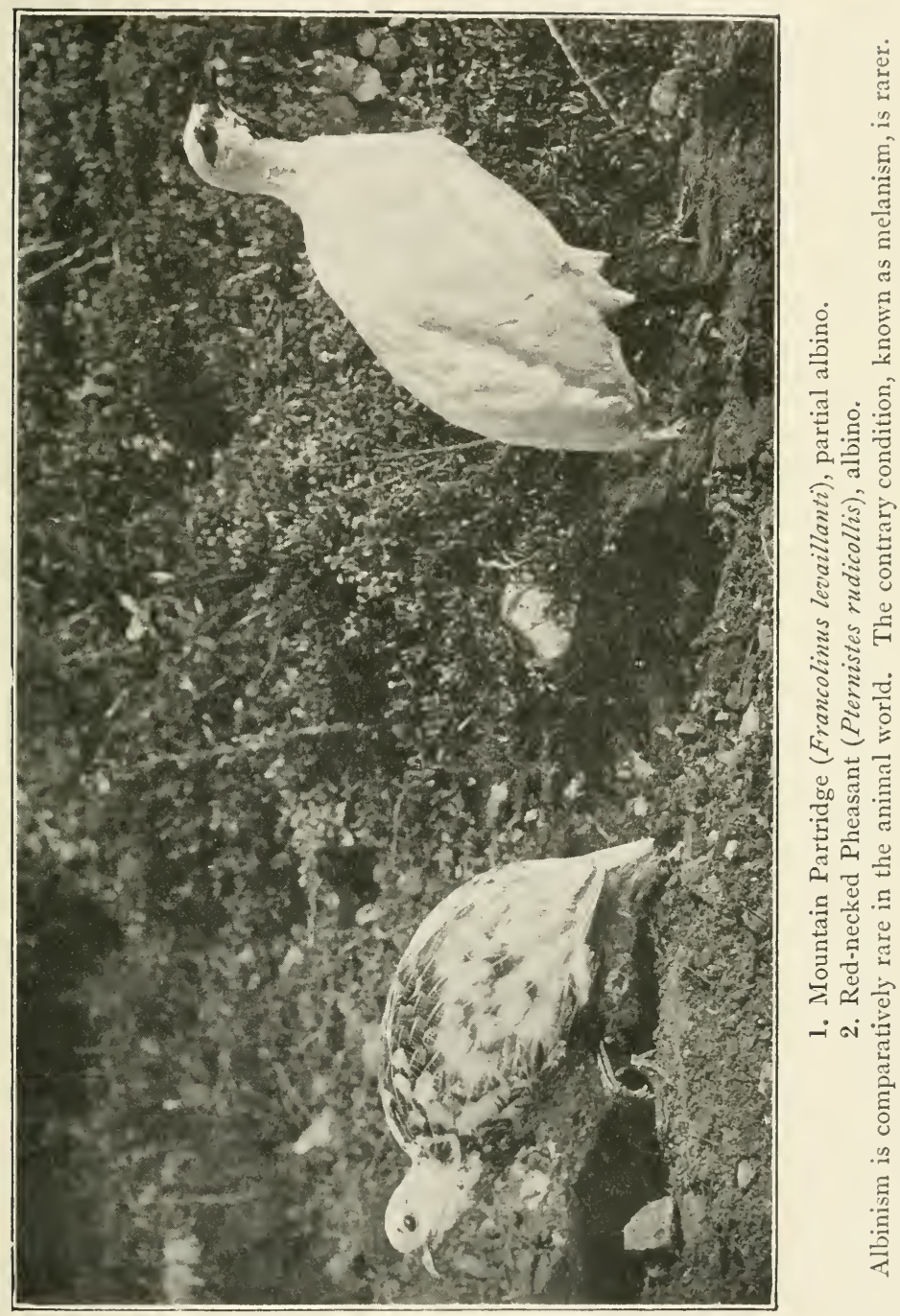


\section{NATURAL HISTORY OF SOUTH AFRICA}

even with a sheep under normal conditions; but when the ewe is in the act of lambing, these birds sometimes attack and destroy both it and the lamb. Many stock farmers, therefore, shoot it at sight or poison it. It is easy, however, to provide a shepherd when the ewes are lambing. The majority of farmers have shepherds for their flocks at all times.

The necessity for the scavenging services of the vulture and carrion crow grows less every year. With the advance of science and education, we in the more settled parts could afford to dispense with the vulture.

When carrion is plentiful the vulture will, however, rarely attack a living animal, even when quite helpless. I have many a time seen them in their hundreds watching for days a dying ox, sitting in rows like a regiment of soldiers waiting for the animal to die.

I once saw fifteen vultures watch a helpless dying sheep for two days, but none of them approached close to the animal until it died. They then rushed in and squabbled furiously over the carcass.

The aas vogels usually assemble and sit like a regiment of soldiers a short distance from a carcass, if it be a large one like that of an ox or horse, waiting until decomposition is well advanced, for two reasons : (I) They prefer decayed to fresh meat; (2) the hide is more easily broken by their beaks, and the meat can be torn off with little effort. Sometimes, when the vulture is not too heavily laden with food, it flies off, and being consumed with thirst, alights, drinks too greedily, and often vomits a portion of the putrid meat, seething with disease microbes, into the water which 


\section{BIRDS AS SCAVENGERS}

stock animals may subsequently drink. It is a much safer plan to bury the carcass of an animal which has died of disease than to let vultures intern it, but the former cannot always be done, for obvious reasons.

In some parts of India the human dead are placed on top of flat towers, and in a very short space of time the vultures pick the bones clean. In Northern Africa and Arabia the people of the villages are exceedingly insanitary in their habits, and if it were not for the sanitary services rendered by the vultures and the hyænas, pestilence would decimate the people.

The gull is one of Nature's finest feathered scavengers. The vulture and the raven are the sanitarians of the hills and veld, and the gull does a like service along the sea coasts.

The gull is a surface feeder, and its mission in life is to eat up dead animal life floating on the sea or cast up by the tide. It occasionally destroys fish, but the harm it does the fishing industry amounts to nothing in proportion to the colossal services it renders as a scavenger. Now and then when a shoal of small fishes are being hunted by carnivorous fish and in their terror come to the surface or into the shallows, the gulls will snap up a few. At other times the cormorants assemble in large numbers, and, forming themselves in crescent formation, deliberately drive a shoal of small fishes into the shallows. Gulls on these occasions hover overhead and snatch up some of the fish, but the number they secure in this way is trifling. Fishermen's stories about the gull being a great devourer of live fish are not true. They have a strong 


\section{NATURAL HISTORY OF SOUTH AFRICA}

dislike to picking up a fish alive even when it is lying helpless on the shore.

During the Government experimental nettings which I carried out in the Zwartkops tidal river during I9I5-16, the gulls hovered round in large numbers and ate up any dead fish which were left on the banks. Sometimes a gull would seize a small fish, and when in mid-air, if the victim showed signs of life, the gull instantly dropped it. On other occasions I have seen mullet leap on to the shore when pursued by a large fish, and watched the gulls swoop down and stand a few yards away and not attempt to seize the fish until its struggles had ceased.

At Algoa Bay the black-backed gulls (Larus dominicanus) do magnificent scavenging work by eating up all the fish offal cast upon the sand and in the water by fishermen.

Some years ago the beach to the south of Port Elizabeth was thickly strewn with dead fish, and the gulls gathered from afar and ate them up. The denizens of the ocean are subject to attacks of epidemics of diseases, as are their more evolved kindred of terra firma. Gulls, by eating the bodies of those that die of disease, are largely instrumental in keeping fish diseases in check. Gulls are therefore guardians of the health of the ocean's population, as well as acting as scavengers of the seashores and dirty, insanitary villages adjacent to the seashore. When pressed for food, gulls penetrate inland for miles in search of grasshoppers, locusts, and caterpillars.

Black-backed gulls, which I kept in captivity for 
observation purposes, were promiscuous feeders ; they devoured anything from caterpillars to offal, carrion, or bread. Gulls at low tide destroy numbers of small marine crustacea and other creatures which are enemies to the eggs and fry of fishes.

Notwithstanding anything fishermen may say to the contrary, the gull is a bird which deserves every possible consideration by us.

But in spite of the immense services rendered us by the gull, these birds are allowed to be slain in hundreds of thousands in various parts of the world to supply the needs of the millinery trade. For instance, on a certain island in the Pacific Ocean 200,000 gulls were murdered for the sake of their snowy white breast feathers. These gulls, at the time, were breeding, but the fiends who butchered them were in no way deterred in the work of slaughter by qualms of conscience for being the direct cause of hosts of nestling birds dying of starvation. Such is an instance of the terrible cruelties inflicted on our feathered friends and allies-all to gratify the vanity of woman. The plumage of a wild bird in a woman's hat has been aptly styled " the badge of cruelty," and it should certainly be so regarded by all humane and sensible people.

The gull has one serious drawback from our point of view. It steals the eggs of other sea birds and kills the nestlings when it gets the chance. At St Croix Island in Algoa Bay it kills considerable numbers of penguin chicks. 


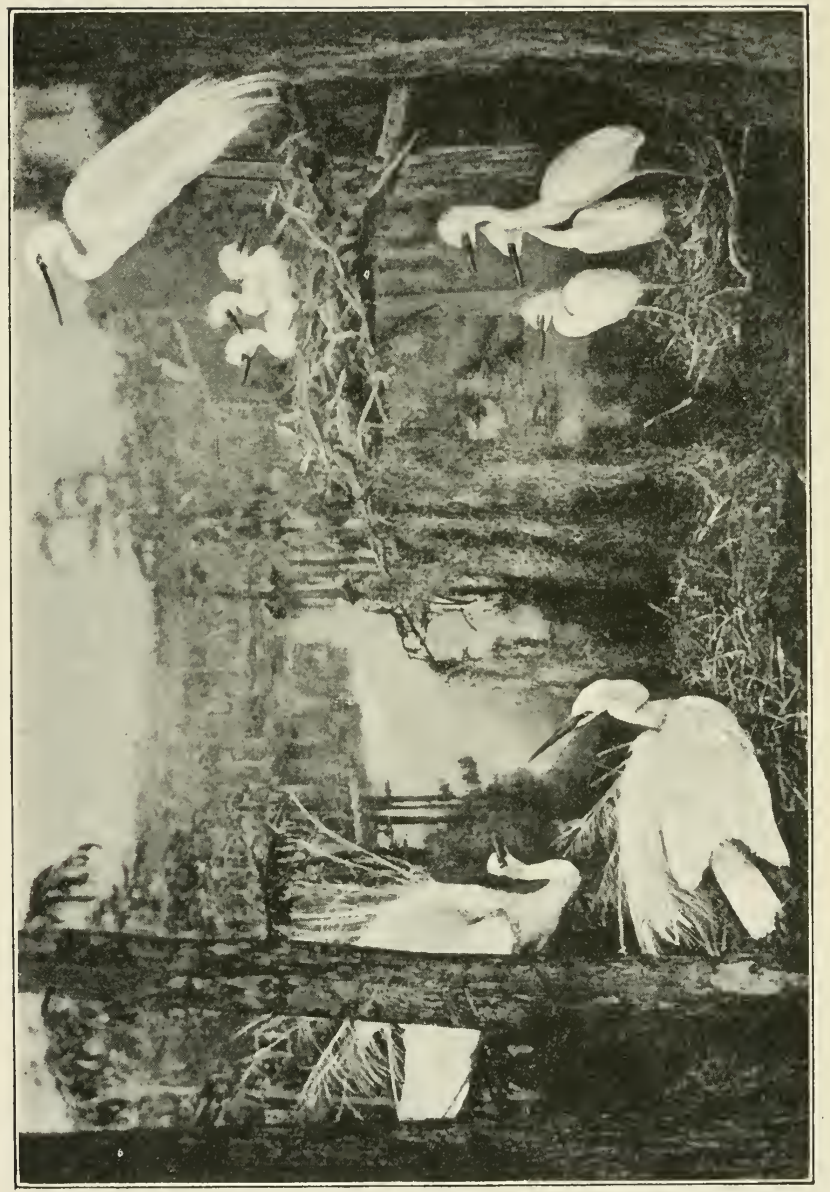

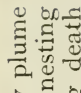

흘.

펑

胥 $b$.

दี

ปี.

is

$-D$ in

들

$\stackrel{\square}{\square}$

도

它完

记 ত己

๘

पू दी

红公完

- द्न० ग

.$=0$

㐘运

छ

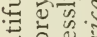

ङ

:

I

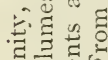

元运

क ०

¿

胥

3 क.

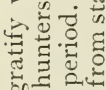

$\stackrel{0}{-1}$ 


\section{BIRDS AND GUANO}

SEA birds are of great value to man as guano producers. Guano is the excrement of the bird. It is a powerful plant fertiliser on account of the abundance of phosphoric acid, lime, and nitrogen it contains.

The ancient Incas of Peru were fully alive to the value of guano, and the birds which produced it were rigorously protected. In 1853 the Peruvian Government valued the guano deposits as being worth $620,000,000$ dollars.

300,000 guano-producing sea birds within a month were slain on a guano island in the Pacific to supply the plume merchants of London so that they might be able to keep pace with the demands of the millinery trade. Can a more brutal and senseless thing be imagined than this?

Attila and his Huns surely were not more merciless to those who fell into their power than we of to-day are to wild birds. Nay, our actions are infinitely more callous and brutal.

Attila with fire and sword mercilessly smote down his enemies. We of to-day strike down our friends and allies. And what makes it even more cowardly, if that were possible, our victims cannot retaliate.

If you sow destruction amongst the native birds, then you reap a harvest of insect plagues. If a law of Nature be violated, whether wilfully or ignorantly, the consequences are the same. There are spiritual laws 
and there are physical laws, and in proportion as we understand them and conform to them, so do our spiritual and physical health and prosperity increase. In the degree that we violate these laws, so do we bring pain, suffering, and travail, both physical and spiritual, upon ourselves.

\section{BIRDS AND FOOD}

The pioneer is usually obliged to depend largely upon his gun for food until he is able to establish himself and begin farming operations. The numbers of wild birds killed for food by these few and far between settlers do not diminish the numbers of birds, for the reason that he also makes war on carnivorous animals. These are the enemies of birds, and their reduction brings about an increase in the numbers of the latter.

At first the destruction of edible birds is a necessity. Then it becomes a sport, and this is usually carried to such extremes that many species of birds have been, and are being, exterminated. For instance, there has recently died in the Cincinnati Zoo the last American wood-pigeon. The American wood-pigeon was at one time so common that the trees in which they nested often broke down under their weight. In I 8 I 3 it was reckoned that there were over two thousand million birds. It was quickly found out that the 


\section{BIRDS AND FOOD}

birds were very good eating, and they were slaughtered by the hundred thousand. In I 869 one town alone near their great breeding grounds sent off 300,000 slain birds a day for six weeks during the nesting period, a total of $\mathrm{I} 2,000,000$ birds. 'The last American wood-pigeon to reach the London Zoo was in I883, and the last wild specimen ever shot was in September 1903. Since then not one of these birds has ever been seen wild, though there is a standing offer of $f, r, \infty \circ 0$ for one.

Fifty years ago the lakes, rivers, and marshes of North America swarmed with wild ducks. Sportsmen, professional hunters, and the agents of plume merchants attacked and slew them in millions. The plume hunters, for instance, shot them down with miniature cannons which were discharged from boats disguised with foliage. Shooting thus into a flock of a thousand ducks, large numbers were maimed and wounded. The majority of these escaped, to die in agony. From year to year this butchery went on until ducks became very scarce. The people living along the west coast of Hudson Bay eked out a hard living by catching fish during the summer. Throughout the long winter their chief means of sustenance were the wild ducks which were cured and packed away in the autumn. One result of the wholesale destruction of the wild ducks was starvation to hundreds of families of hard-working fishermen who, during the most favourable fishing seasons, were only able to gain a bare livelihood.

The fashionable lady who adorned her hat with the 
wing of a duck was unconscious of the fact that she was helping to deprive a colony of poor fisher folk of food.

The right to kill game birds for sport is a subject which can be viewed from many aspects. The quail we know to be a bird of very great economic value. Every quail killed by a sportsman is a distinct loss to agriculture. People pay taxes, and some of the money so raised is spent in encouraging the development of the country. Large Government Departments are maintained for the purpose of furthering the interests of the agriculturist and stock farmer. By protecting the quail on all Government lands we possess ourselves of a helper which renders invaluable service, gratis. The quail, in fact, is an honorary worker in the interests of the farmer and the State.

A sportsman farmer will argue that he, anyway, has a right to shoot the quails on his lands. Yes, he may do so with impunity if there be no prohibiting law, but has he any moral right? Is he not doing an injury to his neighbours? Perchance he is a stock farmer with an abundance of pasturage, and the insects do not trouble him very seriously, or else he does not notice their ravages. So the insects change from the grub and caterpillar stages into winged insects, which fly to the tempting fields of the agriculturist and lay their eggs in the midst of his crops.

Purely selfish considerations should be set aside in matters such as these. We know the quail is an exceedingly useful bird in our struggle to keep insects and weeds in check. Even the dullest-witted person 


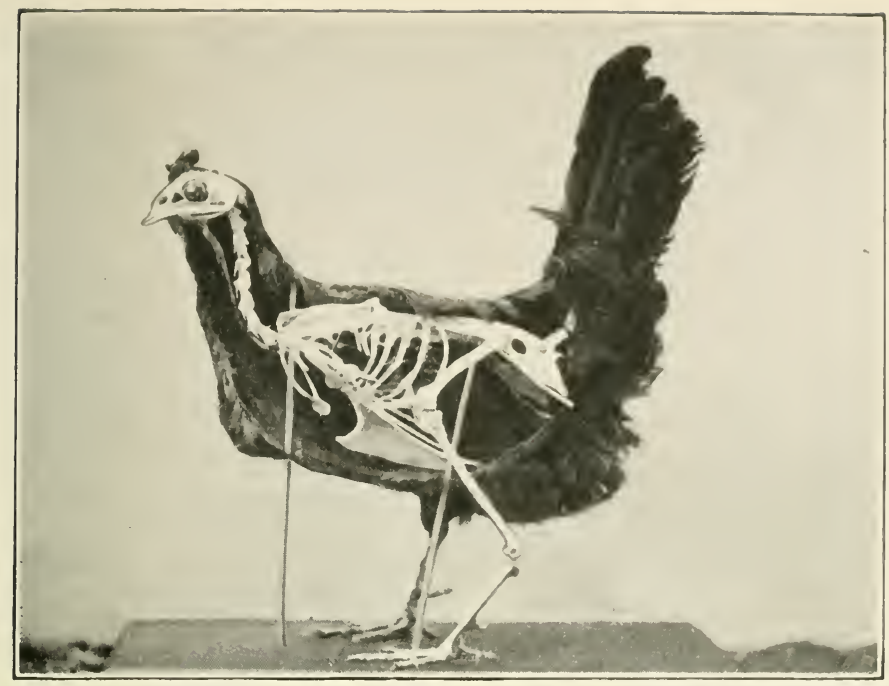

A domestic fowl half-skeletonised.

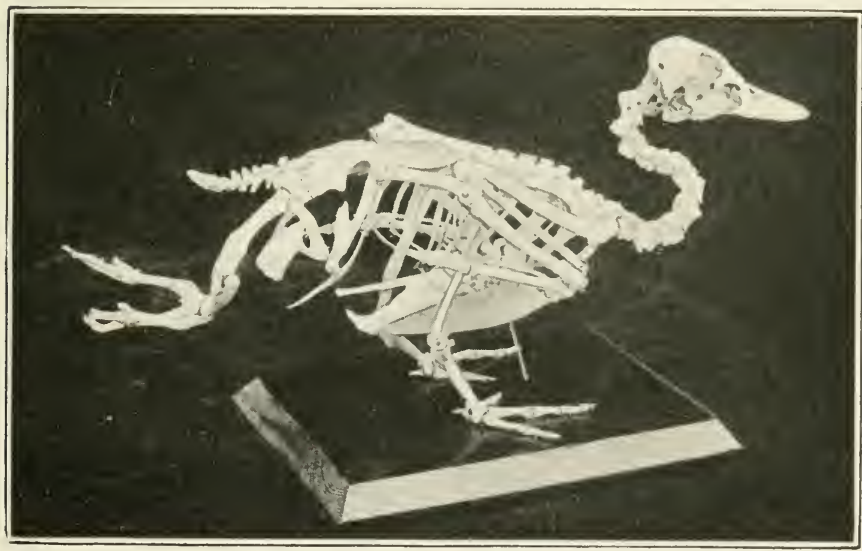

Skeleton of an abnormal domestic duck

This duck had four feet. When resting it tilted itself back on its hind pair of feet, which are represented in the skeleton by the two bones projecting from the back of the bird.

From a specimen in the Port Elizabeth Museun.

VOL. I. 
can realise that an increase in the number of quails would bring about a corresponding decrease in insects and weeds.

The various species of partridges and pheasants are also allies of the first rank in our war on insects and weeds. These birds certainly provide excellent sport, and their bodies are large, plump, and tender, and therefore highly esteemed for food.

We have to pay heavily for the relaxation and food obtained in this way. It is on record that certain Roman emperors and governors banqueted their guests on dishes of prepared nightingales' tongues, larks' hearts, and various small birds' brains. We of to-day think those Romans of old were wickedly wasteful. Yet we are in many ways no better. 'The food value of the body of a partridge would be equal to about a pound of butcher's meat. The natural life of a partridge may be estimated at twenty years, and during that period it would have rendered service to us to the extent of many thousands of pounds sterling. Assuming a partridge only devoured the small number of fifty insects a day, during the course of a life of twenty years the number thus disposed of would total 365,000. Presuming the partridge had been shot when a year old, and these insects had succeeded in reaching maturity, an average of one-half of these insects would be females. These would total i 82, 500 .

Insects produce varying numbers of eggs, according to their species. The termite (white ant) queen lays several thousands of eggs every day during the spring and summer seasons. At frequent intervals 


\section{BIRISS AND FO(OI)}

in summer countless hosts of winged and fertile male and female termites pour out of their ancestral home and fly into the air for a few hours. Descending to the ground, the wings are discarded, and they go forth in pairs to found new homes. Partridges and quails assemble and greedily snap them off the grass and the leaves and twigs on which they alight. For days these birds search everywhere, scratching up) and scattering the loose leaves and soil, and pecking amongst the roots of grass, shrubs, under stones, and in holes for these lurking termites. Every pair of termites destroyed means one colony less. A single colony of termites is capable of inflicting serious damage to man by destroying trees, shrubs, grass, crops, fencing posts, and the woodwork and thatch of houses, etc. Before I succeeded in discovering and destroying a single colony of termites, they had damaged my residence and outbuildings in Natal to the extent of $f_{0} \mathrm{I}, 000$. The repairs to tenants' dwellings, renewals of fencing posts, and other ravages by these pests cost me an average of $f_{1}$ I 50 per annum.

I have found as many as 300 fertile termites in the crop of a partridge, and 85 in a quail. 'Think of it! 300 king and queen termites at a single meal, which means I 50 colonies less of these terribly destructive creatures. In addition, the termite workers make daily foraging expeditions, and at these times the partridges and quails surprise and annihilate them.

A tick lays from 2,000 to I 8,000 eggs, according to its species. Partridges are fond of ticks, and peck 


\section{NATURAL HISTORY OF SOUTH AFRICA}

them from the grass stems and search amongst the roots of grasses, stones, shrubs, and dead vegetation. They scratch up the soil like a fowl for the female tick which has recently dropped from some animal and has hidden herself preparatory to laying a batch of eggs. With unerring instinct the partridge and quail locate the grubs of beetles and other insects which pass the larval stage of their lives underground. Mole crickets, their eggs, and the eggs of the locust and grasshopper are also exposed to view by the powerful beak of the partridge, and greedily devoured.

Should the feeding-grounds of partridges be carefully examined, numerous small excavations will be observed. These are the holes dug by the birds in their search for root-eating grubs.

The holes and scratchings of partridges may frequently be seen on the margins of cultivated fields. The grain eaten by a partridge is as nothing to the tremendous services rendered by it against the destructive insect hosts.

After grain is sown the partridges and pheasants will sometimes dig up a little here and there on the outskirts of the fields; but these birds seldom move far from cover, as they have a wholesome dread of hawks and carnivorous animals.

The scratchings and holes made by partridges amongst growing crops and vegetables are not for the purpose of feeding upon their roots, but to expose and devour the root-eating grubs and other insects, the bulbs of wild plants, and the nodules on the roots of water grasses. 

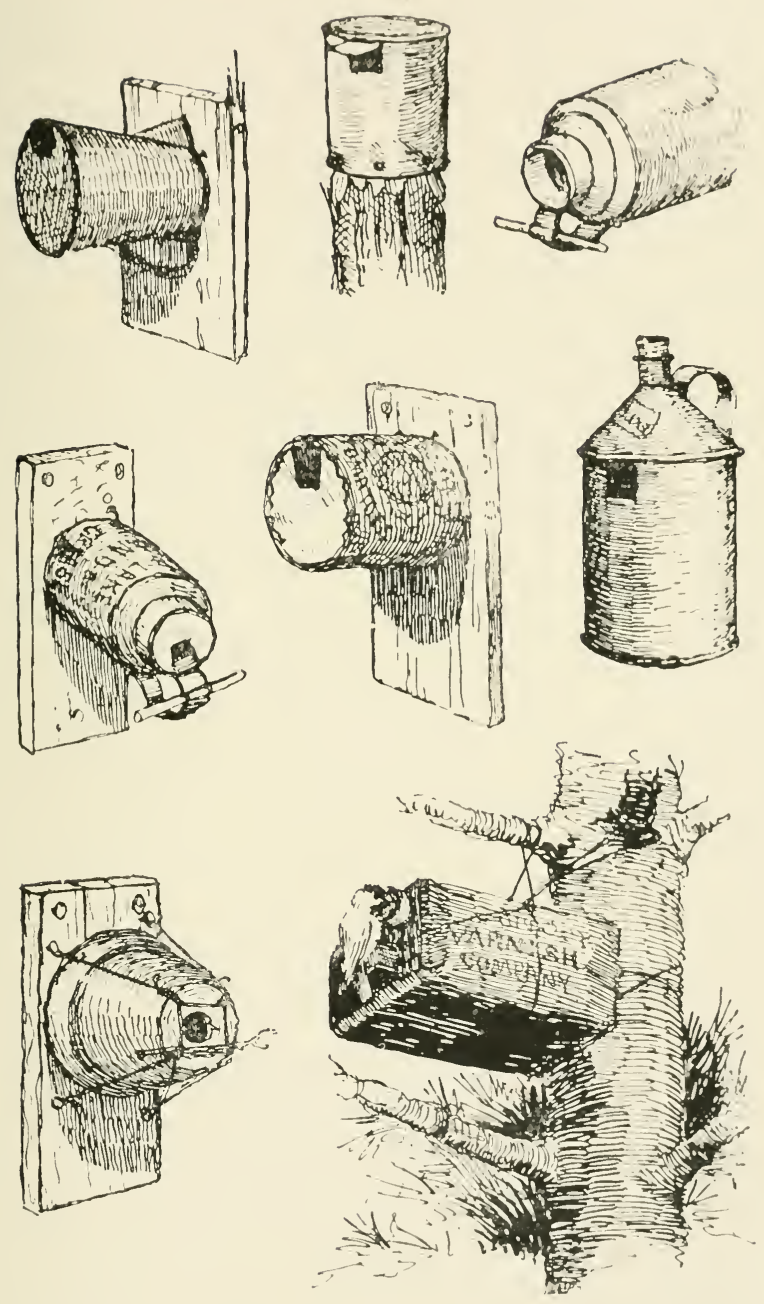

Worn-out tins and old flower pots may be used as nesting boxes. 'They' can be wired or nailed to trees in shady, sheltered situations. 


\section{NATURAL HISTORY OF SOUTH AFRICA}

There are a good many species of partridges and pheasants native to South Africa. 'They lay from four to a dozen eggs, according to their kind, and the young birds are active from birth, the same as the chickens of a domestic fowl. The partridge chicks eat enormous numbers of insects, termites, etc. Although partridges and quails rear their families chiefly during the summer months, yet it is not an uncommon occurrence for them to breed in the winter time, which is the game season in South Africa. Therefore the death of a partridge or quail during the game season may mean the destruction of a clutch of eggs or chicks.

In the winter months, when insects are scarce, the diet of the partridge consists mainly of wild bulbs, berries, weed and grass seeds. In digging and scratching for bulbs and seeds the bird unearths and eats numbers of insects which are hibernating.

We estimated that in twenty years the very lowest average of insects eaten by a partridge would number 365,000 . Taking half this number to be females, and assuming each produced only 500 eggs during one summer season, we should have the total of 9I,250,000 insects. Assuming, again, half of these are females, we should, the following season, have at the same rate of increase, which has been placed at a very low figure, the overwhelming total of 2,28 I, 250,000 insects accounted for by one partridge. Assuming, again, a partridge or quail captures and swallows one fertile female "flying ant" (termite); if this termite had escaped death it would have founded 
a colony. In a short while it would grow as large as a human thumb and be capable of laying thousands of eggs daily. We will assume it lays 2,000 eggs every day for six months in the year. Taking each month at thirty days, we have a total of 360,000 termites.

It is a common occurrence for a partridge to eat at least 200 flying ants in a day. Reckoning half of these to be females, and that they would have laid 2,000 eggs a day for six months in the year, we find the partridge in twelve months has prevented the breeding of a vast host numbering 72,000,000 termites by its act in eating 200 winged males and females. Yet we are content to go on from year to year shooting these birds merely to gratify our selfish instincts. Are we living in an age of reason? Seemingly not.

The guinea-fowl is another game bird which renders highly valuable services to man by warring on his behalf on insect pests, including locusts and their eggs. It is a formidable enemy of the grasshopper, owing to its extreme nimbleness in chasing and capturing these pests. It is out scouring the veld at daybreak for the early worm which goes to bed before sunrise.

The guinea-fowl has a voracious appetite, rapid digestion, and a powerful beak for digging insects out of their underground lairs. It supplements its insect diet with berries, seeds, and various species of native bulbs.

When allowed to increase unduly in the neighbourhood of cultivated lands, it invades the fields and takes a toll of grain. When shot at a few times, however, 


\section{NATURAI, HISTORY OF SOUTH AFRICA}

it becomes very wild and suspicious, and usually retires from the haunts of man.

The bustards (otherwise known as paauws and knorhaans) and the various species of plovers are hunted and shot in such numbers that in many districts they have been almost, if not quite, exterminated, notwithstanding the fact that they render sterling service to the agriculturist and stock farmer. Their chief diet consists of insect and allied forms of life. They devour immense numbers of "white ants,"

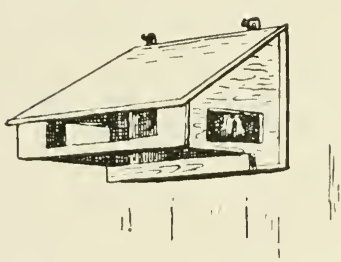

Food House attached to wall of shed. This is a very fine feeding shelter. locusts, grasshoppers, vegetation-destroying grubs, caterpillars, and beetles. The wild duck renders excellent service by checking the growth of water plants, and feeding on water snails which act as hosts in the life cycle of some stock and human diseases.

All past experience shows that the preservation and protection of insect-eating birds is not only essential in the interests of the individual farmer, but is of vital importance in the interests of food production in South Africa.

A true sportsman should surely not desire to raise his gun against any creature which he knew was helping him and his race in their struggle for existence. He may argue he is a townsman, and the birds do not in any way benefit him. 'This would be an extremely narrow and selfish view to take. The villages, towns, and cities depend largely and often entirely on the 


\section{BIRDS AND FOOD}
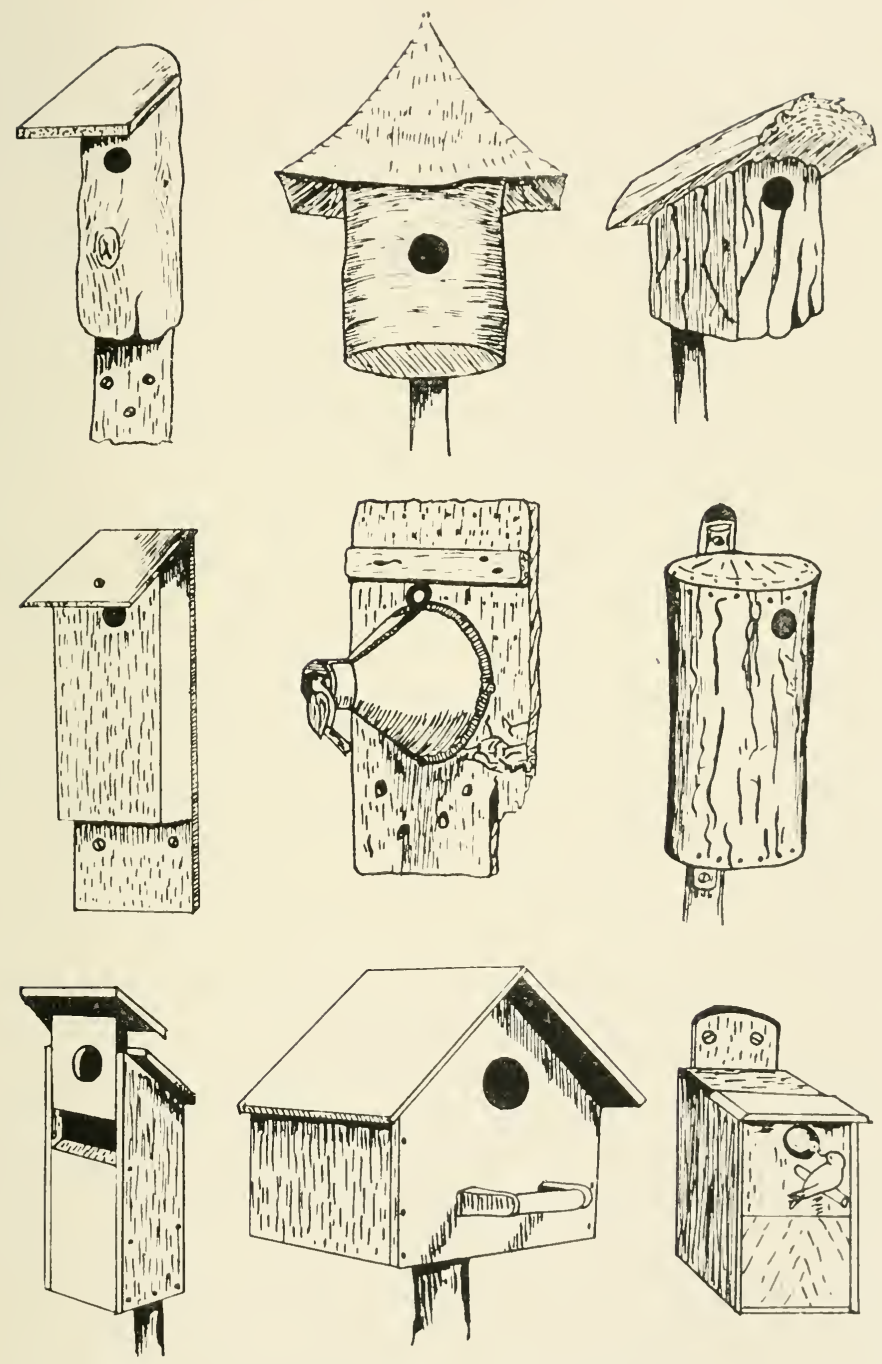

Various types of bird nesting boxes. 


\section{NATURAL, HISTORY OF SOUTH AFRICA}

development of the land and the prosperity of the farmers. A scarcity of birds means a rapid increase in destructive insects, and a corresponding decrease in the prosperity of the individual, the community, and the State.

It would be well for the country if the sportsman confined himself mainly to shooting four-footed game, such as antelopes and hares. These animals are of no economic value. Their mission in life is to act as a check on vegetation, but their services in this respect are no longer required. We need the vegetation for our domestic animals. Moreover, the buck and the hare are very destructive to crops. The farmer would be well advised to ban the shooting of all game birds on his lands.

It might be that under protection they would increase too largely and take to eating his corn owing to the dearth of insects, wild bulbs, weed and grass seeds. Should this occur he can easily reduce their numbers to normal with his gun, and at the same time give them a lesson not to encroach too freely on his lands during the sowing time and when the corn is ripening. Even if rigorously protected by man, the game birds are not likely to increase unduly. They are preyed upon by various carnivorous animals and birds of prey. Rats eat their eggs and young, wire-worms attack their vitals and destroy them, and diseases peculiar to their kind ever and anon reduce their numbers. I have, in my time, been as keen a hunter and sportsman as anyone, but after discovering by personal investigation that game birds were of 


\section{BIRDS AND NATIVE, BOYS}

greater value to us alive than dead, I curbed my destructive instincts and ranged myself on the side of the birds. I now regard them as friends and helpers, and if some of them take a little grain for wages when hard pressed, after they have exterminated the insects on the farm, well then, good luck to them, for is not a good labourer worthy his hire? Surely we do not grudge a handful or two of grain for an entire year's services in the destruction of insects, seeds of weeds, and troublesome pasture-destroying bulbs.

\section{BIRDS AND NATIVE BOYS}

Native children destroy immense numbers of birds. It matters not to them what the species may be. The native herd boys while away their time in seeking for birds' nests, trapping birds, killing them with throwing sticks, and catching them with bird-lime. It is not pure destructiveness which animates the native boy. It is food he is after. If the eggs are large he takes and roasts them in the hot ashes of a fire. The eggs of small birds are left until the nestlings are feathered. They are then taken from the nest, spitted and grilled.

Native boys are very expert in setting bird traps and snares. They kill large numbers of partridges, quails, crakes, rails, bustards, and other ground birds 
by acting in concert. Several boys will advance in crescent form, each armed with a knob stick, and accompanied by dogs of nondescript breeds. When the bird is flushed the boys throw their sticks simultaneously. The quarry, in dodging some of the sticks, is frequently knocked down by one of the others. I have often seen Kafir boys make large bags of quails and partridges in this manner.

To put a check on this wholesale destruction of birds by native boys is a thorny problem. To await the time when the native is sufficiently educated and mentally evolved to be amenable to reason and persuasion in this matter is impossible. Ere that time arrives our native birds, or great numbers of them, will be extinct.

The only practical way to check their practices would seem to be by prohibiting the robbing of nests and the capture and killing of wild birds under very severe penalties, and a rigorous enforcement of the law. It is useless making laws and not providing the necessary machinery to punish those who violate them.

At present, in many districts of the Union of South Africa, the majority of species of birds are protected by law, but snaring, killing, and robbing nests go on as of old, because it is nobody's special business to enforce the law. The majority of people, both white and coloured, are even unaware of the existence of bird protection laws. 
THE STUDY OF BIRD LIFE

\section{THE STUDY OF BIRD LIFE}

Robring birds' nests, if not encouraged, is at least permitted by the majority of parents; the boy, in consequence, looks upon it as an innocent pastime. Every egg taken from a nest is one ally less in our fight against the insect enemy. Boys have a passion for collecting eggs, which are hoarded up for a brief period, then neglected and thrown away, or smashed. 'This indiscriminate collecting of birds' eggs by boys is stupid and senseless. It is very rarely we find a boy making a systematic collection, viz., affixing the name, locality, date, number of eggs in the clutch, colour, when collected, etc. A boy who possesses the knowledge to do this is always sufficiently educated on the subject to never be tempted to take more than a single egg from a nest. However, birds' egg collecting in any shape or form should be sternly forbidden by parents and guardians of boys. It is infinitely preferable to teach boys that birds are their friends and helpers, and as such they should be protected in every way possible.

When seed-eating birds increase unduly in numbers and become a serious menace to the agriculturist, the destruction of their nests and their egg or nestling contents is often advocated by those in authority and by individual farmers. This method of reduction is essentially wrong, for the reason that these birds rear their young at the time when the crops are green and succulent. At this time insect 


\section{NATURAL HISTORY OF SOUTH AFRICA}

pests are at the maximum of their destructiveness, and wise Nature has arranged that birds shall build their nests and rear their families at this critical period in the life of the grain plant. The young of the species of seed-eating birds which prey on the farmers' grain are fed on larvæ, chiefly young caterpillars. 'The appetite of a rapidly growing nestling bird is prodigious, and the number of caterpillars it can digest in the course of a day is phenomenal.

Many species of birds are so suspicious and afraid of man that if their nests are disturbed, or an egg removed, they desert them. Others do not abandon the nests, but they never build a second time in such a dangerous locality. Through lack of knowledge and humane teaching, boys are often guilty of the most diabolically cruel actions. I have seen boys catch the fiskal shrike (otherwise known as the jack hanger) with bird-lime, pluck out all its body feathers, and let it go. I came upon a boy lying behind a shrub with a shot-gun. In front of him was a bare spot where the refuse from a flour mill had been dumped. Every time a flock of weaver and widow birds assembled to feed on the refuse, he fired amongst them. The dead birds were placed in a bag, and the wounded ones fastened by a leg with twine. When I came on the scene there were upwards of fifty wounded, blood-smeared birds struggling piteously to free themselves, and the human demon was looking on and gloating over them. He was the son of one of the leading citizens, and attended a high-class college, too. 


\section{THE STTUDY OF BIRD LIFE}

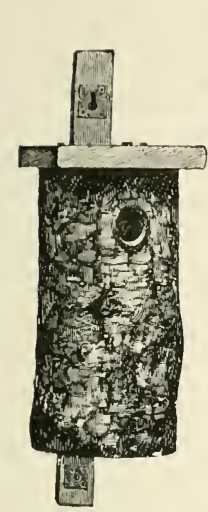

Fig. A.

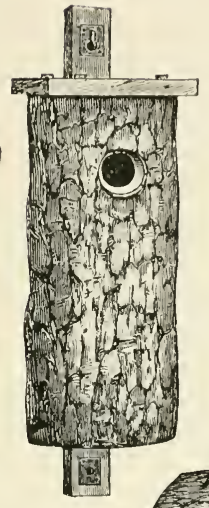

Fig. B.

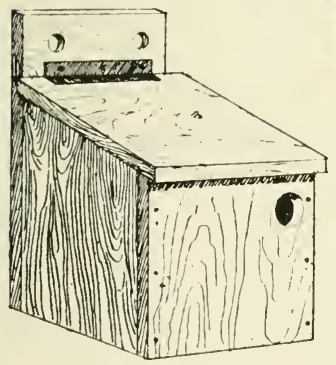

Trec-

Holc

Boxes.

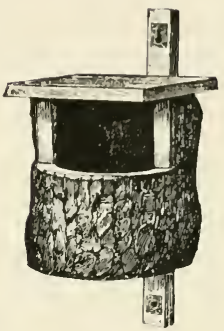

Fig. E.

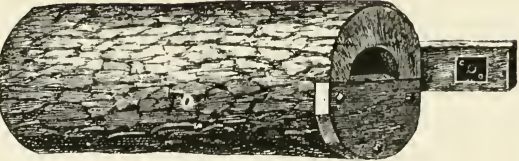

Fig. C.

Walden

Boxes.

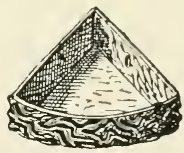

Fig. $F$.

Fig. I, the "Walden."

Figs. A , B, C, nd D.-For Starlings, Woodpeckers, and any kinds of forest birds which build nests with the entrance at the side. If enlarged with a sufficiently big entrance hole they will be utilised by owls.

Figs. E and F.-For Wagtails, Robinchats, Thrushes, Flycatchers, Doves, and other birds which build open nests. 
It is a common pastime for boys to wantonly shoot into the nests of breeding birds. I came upon several boys one day with air-guns, and their targets were the hanging nests of a colony of weaver birds. In order to obtain some facts to write an article on the incident to the local newspaper, I climbed the tree, and with a long, hooked stick pulled the nests within reach. Most of the nests contained fledgling birds, the majority of which were dead or wounded. In one nest the brooding mother bird had been shot through the brain, and her body was, even in death, spread over her eggs. Another parent bird was lying dead in the midst of her children, who gaped wide their mouths for caterpillars when I peered into the nest through a hole made in the top. Not a single nest had escaped those murderous boys. Dead and wounded baby birds or smashed eggs there were in all of them, and parent birds, frantic with grief and terror, flying to and fro.

Can anything equal this in cruelty? Yes, the wearing of the plumes of wild birds is worse, for, in order to obtain those feathers, parent birds are brutally done to death in the breeding season, resulting in hundreds of thousands of baby birds dying miserably of starvation. Why are the birds killed when they are breeding? Because at that season the feathers have attained their maximum degree of beauty.

Boys should be taught to study the ways and habits of birds, armed with note-book and camera. The student of birds rapidly learns to love them. How can it be otherwise when we know that birds 
have nervous systems as sensitive as ours to pain, and that they rival and even transcend us in the acuteness and depth of their affection and higher emotions. Some species of birds, in losing a mate, will die of grief or remain the rest of their lives faithful to the memory of their dead love. Others are frantic with grief for a longer or shorter period, as with ourselves, before marrying again. 'The bird leads a life on a parallel with the majority of the human folk. 'The cock bird courts his lady love even more keenly and persistently than the enamoured young man. He usually has several rivals, each of which seeks by a show of his power in song, flight, display of plumage, or physical vigour, or all combined, to win the young lady's affections. She is coy and shy at first, but, nevertheless, keenly observant. She holds them all aloof until eventually one of them succeeds in kindling the spark of love in her breast. The couple then become engaged, and the rivals take themselves off in anger and disgust. After a period of what human folk couples term "spooning," they marry. Then with joy in their hearts they begin building a home. Both work hard, with intervals to make excursions for food. Tired but happy when the day's work is over, they seek out a secluded nook and, cuddling lovingly together, they sleep until dawn. Eventually the house is finished, and presently the husband bird is sent into a paroxysm of delight on seeing a beautiful egg in the nest. When the full clutch has been laid the parent birds take turn about to keep the eggs warm, so that the developing birdies within them shall

VOL. I.

I 45 


\section{NATURAI, HISTORY OF SOUTH AFRICA}

not perish of cold. In two weeks or longer, according to the species of bird, the eager parents hear the feeble cheep-cheep-cheep of the now fully matured babies in the shells. Presently the shell covering bursts, and the babies are born. The mother carefully takes the broken shells in her bill, flies forth, and drops them some distance from the nest to put bird-nesting boys off the scent. Baby birds grow rapidly and require a large quantity of food. The loving parents never seem to tire, for to them it is a work of love. All day long the farmers' fields, the garden, orchard, wood, and veld are searched for insects. To and fro the parent birds fly from dawn to dewy eve. Often, owing to unfavourable weather and other reasons, barely sufficient insects can be procured to satisfy the appetites of the children, and the parents go to bed supperless. The babies have the first claim, and should the day yield few insects, all go into the stomachs of the children, and the parents are content to fast, trusting to the morrow to furnish a better harvest.

Alas! how often do we bring woe and blackest grief into these happy homes? Coveting the beautiful plumage of the father bird! Seeing him busily searching in the orchard or garden for caterpillars for his children, and misinterpreting his actions! Or in the spirit of sheer wantonness he is shot to death with catapult, air-gun, or shot-gun. His plumage is stripped from his body to decorate a woman's hat or to add to a collection of birds' skins. Perchance his feathered body is simply left to rot where it fell. Would that every bird-slaying boy could see what happens as the 
result of his thoughtless act. 'This is what he would see. The mother bird soon misses her mate. She grows uneasy, and calls again and again to him. Then her uneasiness increases to alarm, and she flies from tree to tree calling, calling, calling, alas! in vain, for her mate is dead. With a sinking heart and all joy gone out of her life she works for her children, making the neighbourhood resound with her piteous calls, hoping against hope her dearly beloved mate may hear her cries. Nobly, faithfully, but wearily she slaves to provide sufficient food for the little orphans. Retiring to rest, heavy of heart, in, on, or near the nest, she slumbers uneasily and, forgetting that her mate is dead, she ever and anon in bird language murmurs endearingly and snuggles up to him, to awake and find herself alone. The struggle proves too much for her. Emaciated and weary in body and mind, she dies of a broken heart. What of the baby birds? They die of starvation.

Is this picture overdrawn? No, not in the slightest. I have watched the tragedy in my own garden many a time. The cock bird had flown to a neighbour's garden to collect caterpillars, and never returned. The human folk in return for his services had murdered him.

God has given us the means to make our struggle for life a success. Nay, more; he has placed knowledge within our grasp by which our kind can overspread the earth and live and thrive even in great cities. In the degree that man turns the golden grain of knowledge to practical use, so will he advance and overcome 


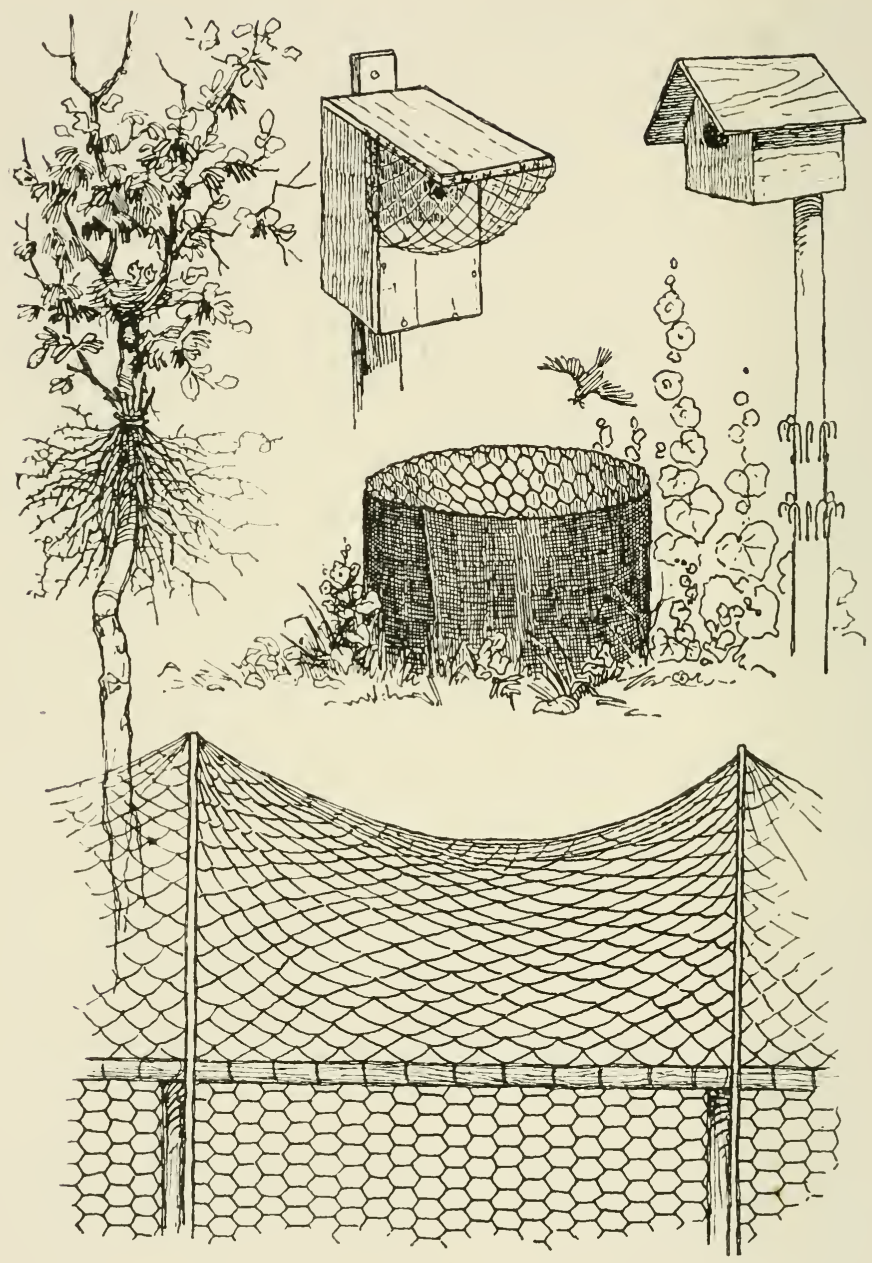

Cat-proof fence and other devices for protecting birds from cats. (From Economic Biology Bulletin No. 2, Massachusetts State Board of Agriculture, 1916.) 


\section{'THE STUDY OF BIRD LIFE}

Nature's adverse forces. With his weapons he has obtained mastery over the entire sub-human kingdom. Is his rule a wise and humane one? Is it dictated by reason, or by prejudice, superstition, individual self-interest, and the wanton gratification of the barbarian lust of killing-the joy of spilling blood?

Of all the sub-human tribes and races under man's sway, the birds are one, if not the most valuable. Without their aid he could not exist, and yet they are a possession on which he sets the least value. Those who seek to teach him why the birds are such valuable allies and helpers are disheartened and discouraged by the indifference of the various authorities and the people generally. It is those people who are ignorant of their ignorance, who clog the wheels of human progress. If a severe check is not put upon the present wanton and wholesale destruction of birds, man will bring upon himself a terrible retribution-a disaster which will be without parallel in the history of his race.

The following remarks by James Buckland are both forcible and true: "Wherever there are birds whose plumage is suitable for millinery, there will the cruel and rapacious agents of the feather dealers be found engaged in orgies of wasteful destruction. Wherever there are birds that are classed as 'game,' there hastens the market hunter to kill, kill, kill, so long as any saleable thing remains to be killed. Wherever there are species that have been harried by man to the brink of extinction, there will be the collector also, anxious to obtain the last lingering 


\section{NATURAL HISTORY OF SOUTH AFRICA}

representatives of a race before his rival gets a chance to do so. Wherever there are birds whose eggs arc valuable, there hurries the egg collector to destroy, not only the embryonic life, but often the mature life as well, by shooting the bird that laid the egg for the purpose of identification. Wherever in the wild places of the earth there are birds which are considered to be 'good sport,' there saunters that vandal of creation, the hunter of means and leisure, to expend on the most beautiful and the most harmless works of Nature his instinctive desire to kill."

"Do you ne'er think what wondrous beings these?

Do you ne'er think who made them, and who taught The dialect they speak, where melodies

Are the interpreters of thought?

Whose household words are songs in many keys,

Sweeter than instrument of man e'er caught !

Whose habitation in the tree-tops even

Are half-way houses on the road to heaven !"

LONGFELLOW.

\section{BIRDS AND HUMAN PROGRESS}

BIRDS, we now know, are necessary to man in his struggle for food. The human race is steadily increasing in numbers and spreading out over the world. When a new country is colonised there is ample clbow room; and the settler, muddling along in any sort of haphazard manner, is in little or no danger of 
starvation. As the population increases in numbers, the struggle for existence becomes increasingly keen. Men can no longer.afford to live more or less in a state of Nature ; or, to use a South African term, "Sit on the stoep and watch the wool growing on the sheep." Competition rouses him. He finds he must progress or be submerged and perish off the face of the earth. Knowledge gives him power over the forces of Nature. He who sits at home while a plague is sweeping off his cattle is not the kind of man who will make any headway to-day. An ever-increasing population can only be sustained and maintained by taking advantage to the full of every discovery of science. Too much money cannot be spent on educating the people and in helping scientific institutions. Education and human advancement go hand in hand. Every useful discovery should be taken full advantage of. We have, for instance, only lately discovered that we have in the bird tribe an asset of the highest possible value. We know that if wild birds are carefully safeguarded they will not only make our struggle for existence much easier, but by their aid our race will be enabled to multiply on the face of the land.

If it were not for the damage inflicted upon us by insects and their kindred, we could produce at least twice as much food. Not only this, but much of the money, time, and energy expended at present in warring on insects could be turned into other channels.

If there was a vast forest of magnificent trees, and ignorant men were allowed to fell the trees merely for the sake of gathering the flowers or berries on them, 
we would indignantly demand that such vandalism should cease. On the other hand, we stand idly by while the birds, which are God's agents in keeping down insect pests, are slain simply for a few feathers or to provide a mouthful or two of food. One bird alive is worth a thousand dead.

Millions of money is spent on irrigation and in fighting insects by artificial methods, but little attention, money, or thought is given to the utilisation, protection, and encouragement of Nature's insect destroyers by the states and nations of the world.

\section{ESTHETIC AND SENTIMENTAL VALUE OF BIRDS}

Without birds it would be to us like living in a house with interior walls unplastered and no decorations or other artistic furnishings. Man is not destined to live for the gratification of animal desires and passions only. He has been created for higher purposes. He is destined to go on steadily unfolding and developing his moral, altruistic, and spiritual faculties. A muscle will not grow in strength unless it is systematically exercised. Neither will any of the brain centres. If a man lives in the back kitchen of his brain, or, in other words, if he only uses the parts of his brain which he has in common with lower animals, those brain centres will grow increasingly 


\section{SENTIMENTAL VALUE OF BIRDS}

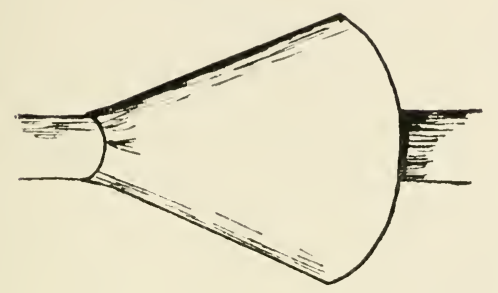

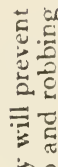

总

4.

츨

크류

¿

흥

ป

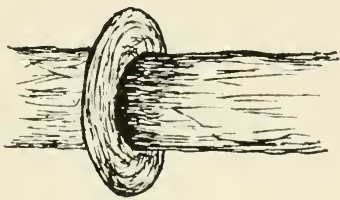

อ.․․

उ

屯ै

范出.

ट

记

๘

$\Xi$ क

बै

$\longrightarrow$ - $\longrightarrow$ 章

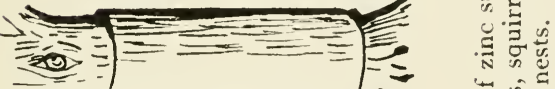

की
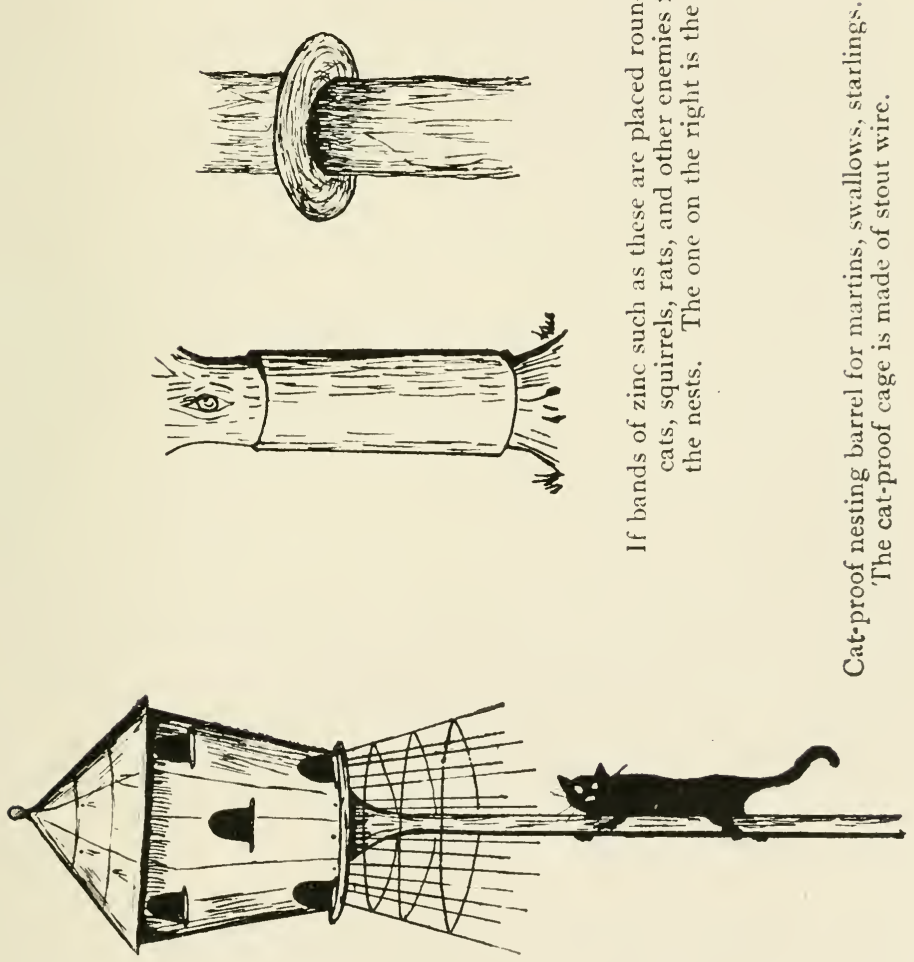
strong, and the others correspondingly weak. He will then be a slave to his passions-a man devoid of moral and æsthetic sense. Such a man is lower than an animal, for the reason that the former often indulges his animal appetites so freely and so frequently that he loses control of them. They become abnormal, and master him. For instance, he will slay for the mere lust and pleasure of killing, and boast aloud of his prowess. On the contrary, the carnivorous animals kill for food only, for they know no other means of sustaining themselves.

The crocodile is presented to us as the incarnation of all that is cold-blooded, cruel, and implacabledevoid of reason or moral sense. Yet this same reptile can teach us a lesson. When lying basking in the sun, birds gather around its head and feed upon gnats and flies which disturb its slumbers. When the crocodile gapes its jaws to allow the sun rays to warm up the cavernous depths, the birds do not hesitate to pursue and snap up their prey even inside those terrible jaws, which could snap like a spring trap. The crocodile is only a reptile, yet it is sufficiently intelligent to recognise the bird as a benefactor, and treats it as such.

What return does man make for the services of birds in making it possible to grow crops or to save his pasture lands and forests from annihilation? Does he befriend and protect these true and faithful allies? No; on the contrary he ravages their homes; wounds, maims, and kills them. The remnant, in terror, flee to the wilderness, or, forced by hunger, 


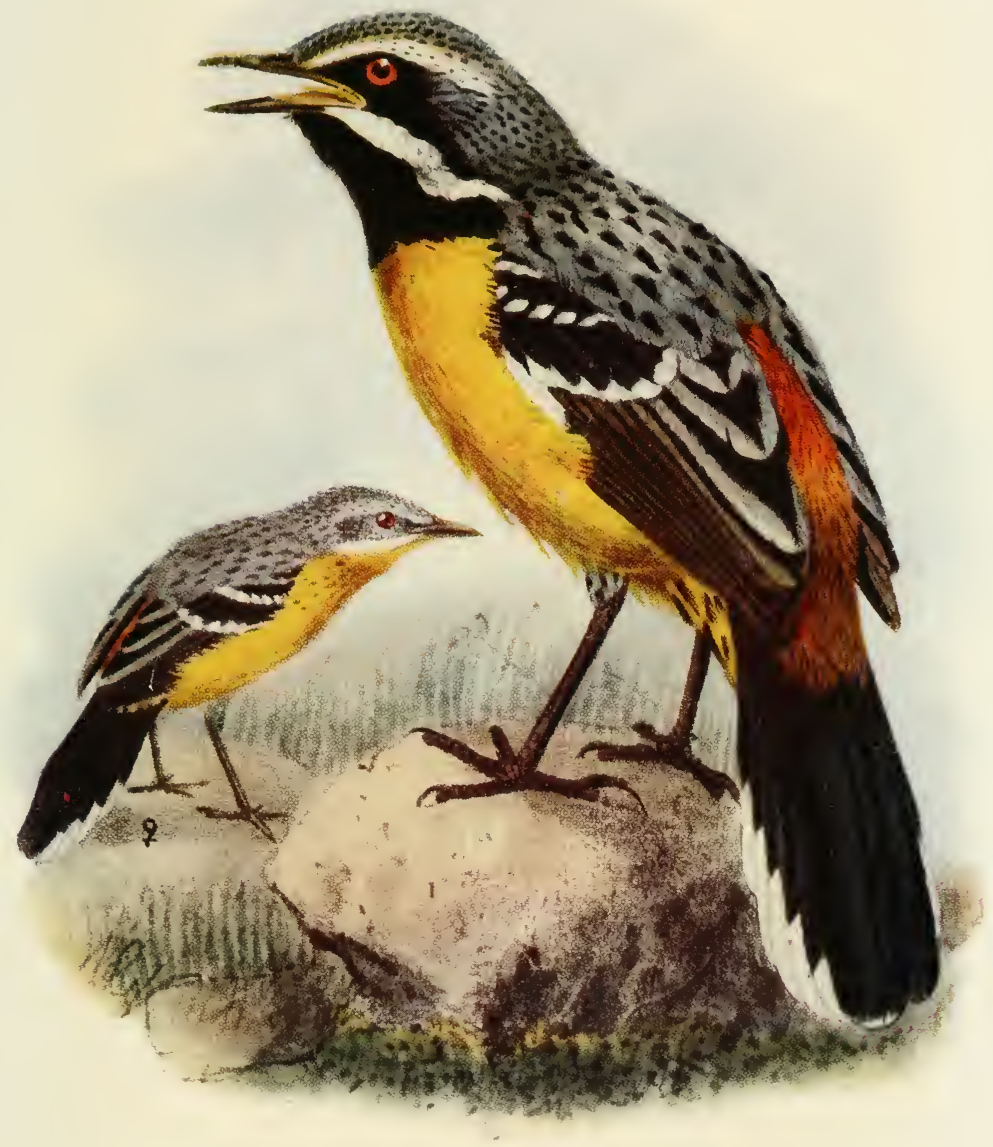

I'LATE IV. - Orange-breasted Rock-Jumper (Chactops aurantiacus). The Rock-Jumpers are the guardians of the pasturage and scanty regetation of the stony hills 



\section{SEN'TIMEN'TAL VALUE OF BIRISS}

they visit his fields and pasture lands and snap up the insects by stealth, retreating in wild alarm on sight of their persecutor. Man's hand has ever been raised against those of his own race who, seeing farther in advance of the masses, seek to benefit them. Christ sought to raise the people to a higher moral and spiritual plane. His reward was death on the cross.

The Greek philosopher, Socrates, taught the people to think of higher things than the gratification of the desires of the flesh only. He sowed the seeds of wisdom, and his reward was death by poison. So it will be until man directs his life by an educated intellect, acting in combination with the moral and spiritual organs of the brain. There is a subtle, uplifting, spiritual influence in the study of birds and their ways.

Wandering into the fields weary and depressed, the cheerful, bright, optimistic calls and cries of the birds and their happy, joyous ways and beautiful forms inspire one to renewed effort.

What would the woods and fields be without birds? As barren and unattractive to the æsthetic senses as the flowerless, weed-covered garden. Authors, artists, and poets rave of the emotion-stirring songs and the glorious gracefulness of birds, and the inspiration they thus receive in their work. Can anything be more elevating to the soul or more stirring to the higher emotions than the song of a lovely bird singing to his mate while she contentedly sits close on her eggs, her entire being suffused with love for her companion and solicitude for the welfare of her eggs? 'The song 


\section{NATURAL HISTORY OF SOUTH AFRICA}

of a bird! What does it mean to many? A signal to stealthily creep through the shrubbery and slay the songster.

A beautiful bird upon a bough suggested food or feathers to him, and nothing more.

For days and weeks at a time I have dwelt alone with Nature and the birds in the forests of Natal, content to study their ways and habits with field glasses, while lying hidden from view. Lying under a forest tree wrapped in a blanket on a warm summer's night, I lay listening to the monotonous hoot of the rat and mouse devouring owl, and the mournful cry of the insect-slaying night jar.

On the first peep of dawn the woods resounded with emotion-stirring songs and the nerve-bracing calls of its feathered inhabitants. One's mind in such surroundings cannot dwell upon gross and material things. Spiritual desires and emotions are awakened, and the soul feels its kinship with the Creator.

A friend, whom I shall never forget, was a Boer farmer in Natal. He was one of Nature's gentlemen, and his word was his bond. His homestead was surrounded with plantations which were teeming with insectivorous birds, for that farmer and his children never raised a hand against these beautiful living jewels of the woods. Once he caught a Kafir boy robbing an oriole's nest. 'The boy wended his way home wiser but sadder. Many scores of times I have sat on that wise and humane farmer's stoep watching the birds, and listening to the stories of the 


\section{HOW TO SAVE OUR FEATHERED ALIIES}

children about their ways and habits. 'The birds were their friends and companions, and the thought of doing them an injury never entered their minds. Life on a farm would be joyless indeed without the presence of birds. There is an uplifting, spirit-awakening influence in the study of birds which no other form of life can inspire.

"The lack of humane education is the principal cause of crime."

\section{HOW TO SAVE OUR FEATHERED ALLIES}

Argument and persuasion fall unheeded on the ignorant, the uncouth, and the vicious. They cannot be made to realise the harm which they do by wantonly destroying birds. Many birds to them are of evil omen, and therefore should be destroyed. Others provide a meal, or their plumage or skins will bring in a few coins. With others the desire to kill is still strong within them-an instinct which has come down through the ages from our remote ancestors, who lived by the products of the chase. So, in order to gratify this brutal instinct, they attack the most beautiful and lovable of God's creations-the birds. Such people can only be restrained by fear of punishment.

Stray domestic cats in and about towns and villages, and homesteads on farms, destroy great numbers of 
nestling and adult birds. Instead of destroying the surplus kittens at birth, they are frequently allowed to live and are subsequently given away to promiscuous people, or permitted to run wild. If the former be their fate they are invariably neglected, ill-used, and starved. If the latter, they gain a livelihood by preying largely upon wild birds.

A Bird Protection Act and an Act forbidding the importation and exportation of the skins or feathers of wild birds are essential in order to deal effectively with those who are not amenable to moral suasion.

The kernel of the evil is want of knowledge as to birds, their habits and economic value.

The conservation of the native birds is of vital importance to the country-how vital few, other than ornithologists, realise. Educate the school children, and in a generation the problem will be solved and for all time, for the children of to-day are to be the parents of to-morrow. Parents possessing this special knowledge can be trusted to hand it on to their children.

It is not necessary to interfere with the present curriculum of the schools. It is eminently desirable that school children be taught the natural history of their country, with special reference to its economic side. This could come under the heading of Nature Study.

The public museums could be made of much greater value in this respect by having economic series of exhibits with explanatory labels.

It could be made a duty of the curator or a competent member of the staff to make periodic tours and 


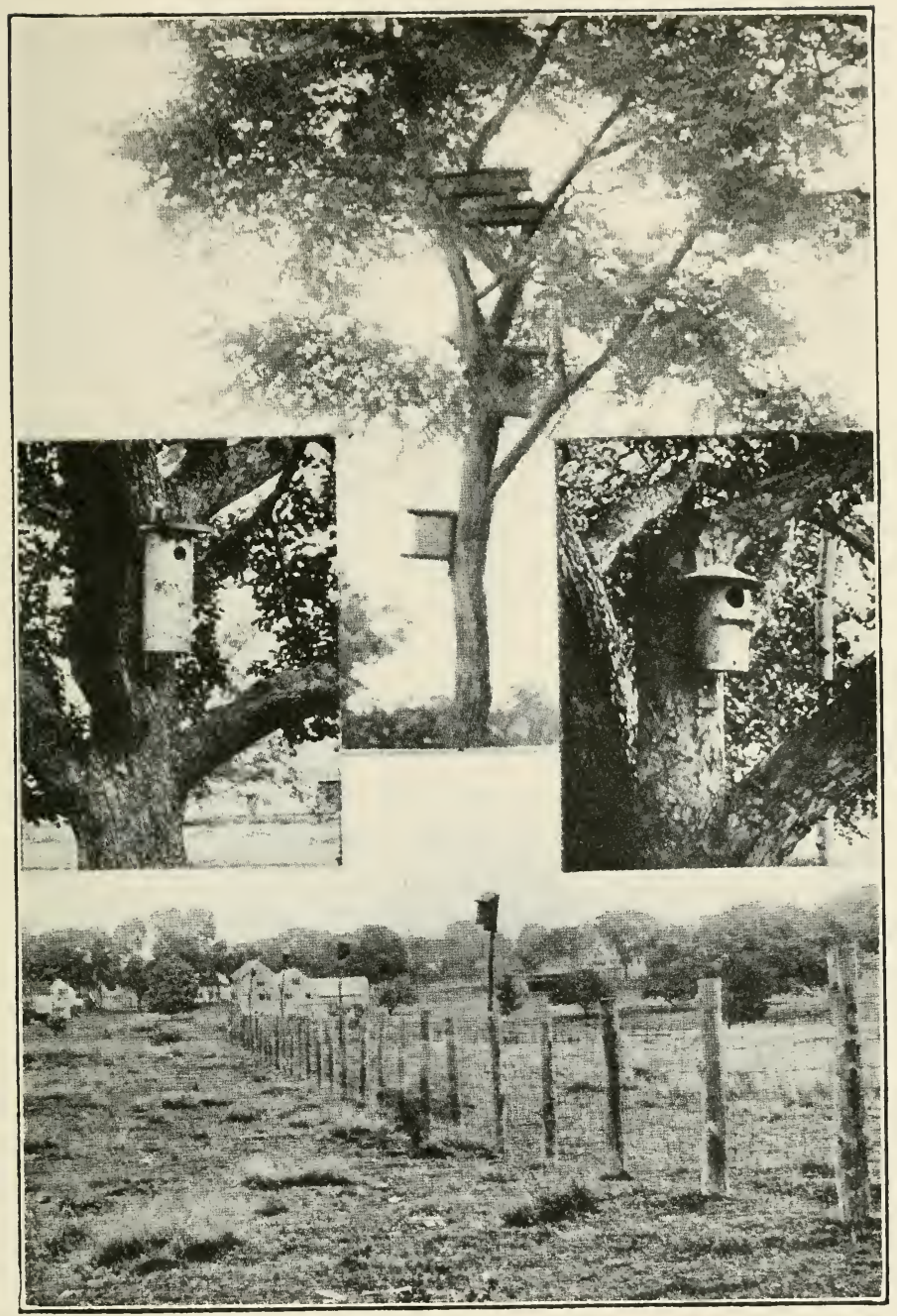

Nesting boxes in position on trees and along a fence. 
give lantern lectures to the various schools. There need be no overlapping if a list of the schools to be visited is furnished to every museum authority.

The subsidy which it would be necessary to grant each museum for this work would be a mere triflea drop from an ocean in comparison to the economic value of the work to the State. If a thorough systematic educational campaign was launched, and this one subject alone taught, viz., the economic value of native birds, South Africa would, within ten years, be richer by at least a million sterling every year.

Silently and unseen the insect hosts are taking a heavy toll of the fruits of man's industry. The locusts are an example. By reason of their size and habit of congregating in great swarms they attract special attention. If we slackened in our defensive and offensive they would, in a season, easily cause loss to the country of half a million sterling.

The destructive grasshoppers are a hundred times more abundant than the migratory locusts, even when the latter are at their worst, yet because they are scattered broadcast throughout the land and do not congregate like the locust in great swarms, the ravages they commit are not noticed; and instead of warring on them, we turn our weapons on the birds which God has given us to keep them in check.

As the birds increase in numbers, so will the grasshoppers and other plant destroyers decrease. Then in God's name why not take practical measures to increase the natural enemies of these foes of the human race? 
If a mighty host of armed men attacked us, and our very existence was threatened, we would gladly avail ourselves of proffered help from an ally to beat back the foe. Under such circumstances would we be justified in turning in fury upon our ally because a few hungry individuals of the army fighting for us took a little food now and then from those on whose behalf they were fighting? Assuredly not. Yet this is what we are doing with the birds, which are not only helping us in the fight against the ravening hordes of insects, but which are actually doing ninetenths of the fighting.

"'The greatest of all needs is more education of the heart." - Hiram Maxim.

\section{NATURAL ENEMIES OF BIRDS}

All forms of life on earth have their natural enemies which prevent any increase in numbers beyond the requirements of Nature. A constant warfare is being waged. It is indeed a struggle for the survival of the fittest, both mentally and physically. The struggle for food and the dread of falling a prey to some enemy keeps all creatures from stagnating. Those individuals of a species which have a greater measure of intelligence and bodily vigour than others of their kind are the most likely ones to survive and perpetuate the race, resulting in the conservation and preservation of

$$
\text { VOL. I. }
$$




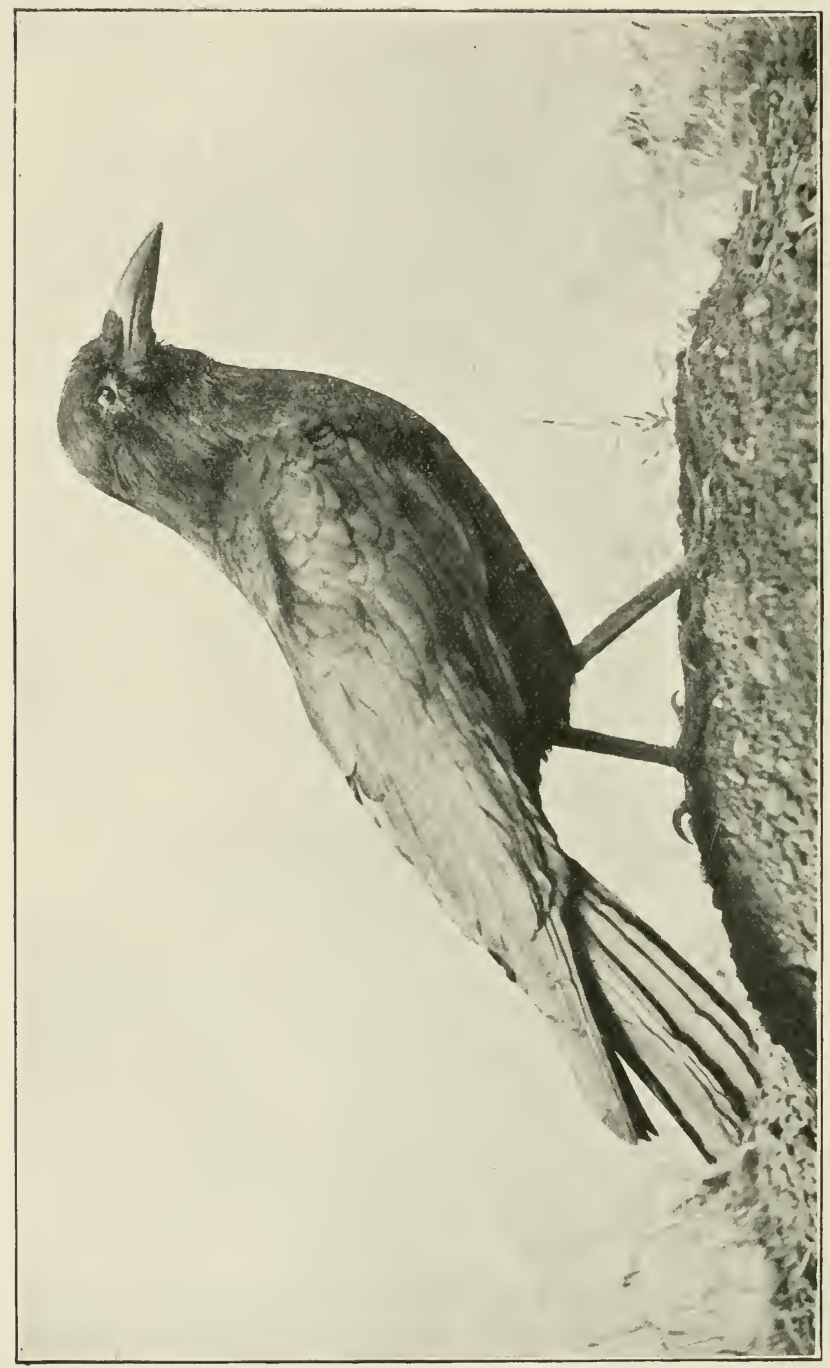

롱

동.

\&

है

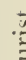

जี

雳

苂造

뉴 至

进

吉芯

ธ. $\approx \tau$

แ० एक

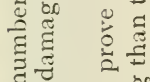

प्र 4 की

के

을

茟 क :

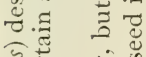

.

इั ठ छ

กิ०

今

స广

ขِ

능. 워

\& $\infty$ o

ह @ छ

छे

记

๘こ

플

भ.

-

¿

U 0 吃

푱 क

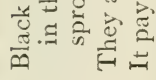

E 
physical health and a progressive development of intelligence from generation to generation. Should any species of creature succeed in increasing abnormally in numbers, the balance of Nature is soon restored, because their enemies, owing to the abundance of food, also increase in proportion. For instance, when insects are numerous, birds have plenty of food for themselves and young, and they, in consequence, become more plentiful. The birds from all the surrounding parts also flock in for a share, and remain so long as there is food for them.

So it is with other forms of life. When vegetation increases abnormally, the herbivorous animals flock to it and the carnivorous animals follow. The balance of Nature is perfectly adjusted, and swings backwards and forwards like the pendulum of a clock, until man steps in and dislocates the machinery.

Man kills great numbers of the natural enemies of birds, and it might be considered that as a consequence birds would increase abnormally. Man, however, as a general rule destroys more birds directly and indirectly than all these natural enemies, and counteracts the good he does in destroying some of the enemies of birds. Then again, it must be remembered that the artificial cultivation of plants and domestication of animals provides enormous facilities for the abnormal increase of insects. Therefore a corresponding increase in the number of birds is necessary. Purely insectivorous birds, if not persecuted by man, would fluctuate in numbers in accordance with the abundance or otherwise of insect life. On the contrary, birds which supple- 
ment an insect diet with grain and fruit would become increasingly troublesome and destructive should they increase abnormally, for, driven by hunger, they would attack the orchards and crops in ever-increasing numbers. Should such an increase occur, and after mature consideration and observation it was found these birds were really too numerous, their numbers could be reduced. No man should ever come to a

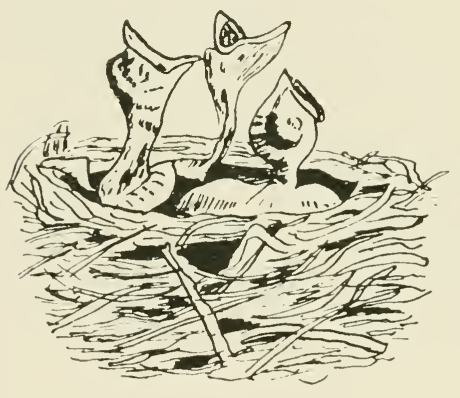

I Iungry Baby Bird:. hasty decision, however, for a large increase in the number of birds is frequently a sign of unusual activity in the insect world. Birds are keenly intelligent and more alive to the right and best conditions for rearing their young than are the majority of human folk.

The large number of birds often seen on cultivated farms during the summer time is not necessarily because they have foregathered to attack the'crops.

Insects breed on cultivated lands at a phenomenal rate. The winged mature insects flock in for miles around and lay their eggs amongst the crops, knowing full well that their offspring have greatly increased chances of reaching maturity than if obliged to subsist on the hard and limited native vegetation. Soft insects, such as grubs and caterpillars, are necessary food for the young birds, and naturally the parents 


\section{THE DOESTRUCTIVE RODEN'T}

choose the neighbourhood of a farm for preference when the time arrives to rear a family.

Birds have many natural enemies. Carnivorous animals, rats, and snakes levy a heavy toll. 'The venomous boomslang (Dispholidus typus) and the mamba (Dendraspis angusticeps) are highly destructive to eggs and nestlings. Another snake known as the egg-eater or eier vreter (Dasypeltis scabra) subsists almost exclusively on the eggs of birds. The monitor lizard or leguan (I aranus niloticus) supplements its diet of frogs, grasshoppers, and crabs with birds' eggs and nestlings. The common brown or Norway rat (Mus norvegicus) has been introduced into every country of the world, and thrives exceedingly. It levies a heavy toll on the eggs and young of birds which nest in the vicinity of man.

Birds of prey attack and kill a limited number of useful birds, and a few species of shrikes and crows occasionally eat eggs and nestlings. However, until man threw his weight into the scale against them, the birds throve and fulfilled their mission in life.

\section{THE DESTRUCTIVE RODENT}

Closely rivalling the insects in their crop-devouring powers, we have the rodents known as rats and mice. In South Africa there are large numbers of species native to the country, and three imported kinds, viz., 
the brown rat (Mus norvegicus), black rat (Mus rattus), and house mouse (Mus domesticus).

The loss they occasion to man the world over is incalculable. The produce consumed in South Africa alone by rodent animals would feed a large army of men and horses. They prey upon all forms of good and useful vegetation. They attack the forests, pasturage, growing and stacked corn, grain in bags, seeds, root crops (both in the ground and barn), young trees and shrubs, buds, fruit, and even flowers. Anything and everything of an edible nature to man and his domestic animals they gnaw and devour. Not content with these crimes, they overrun his dwellings and stores, nibbling, tearing, and wasting in their wantonness. Some kinds of birds take fruit or grain now and then from man, but they, with but few exceptions, render sterling service for it.

The rat and mouse, on the contrary, are out-andout pests-vermin of the purest water. They constitute a steady and continuous drain upon mankind. The quantity of good grain eaten by rats and mice in the various countries of the world would be sufficient to feed at least fifty million people. Another fifty millions could be sustained on the other kinds of foodstuffs eaten by these ravagers of the produce of man's labour.

Some of the rodents are active carriers of diseases. For instance, the rat harbours a flea which can inoculate man with bubonic plague. The brown rat visits the garbage barrels, privies, sick chambers, cesspools, drains, etc., and gets smothered with the germs of 


\section{THE DESTRUCTIVE RODENT}

various diseases, and distributes them throughout human dwellings, and even on his foodstuffs. Man has warred from time immemorial on rats and mice. He has called in the aid of the inventor, the chemist, the bacteriologist, and the cat, but he has failed as lamentably as in his campaign against insects. With all his efforts he can barely keep them in check. Should he relax his pressure for a single year they would overwhelm him.

Surely Nature has not so ordered it that man should be overthrown by the rat and mouse. Assuredly not. Nature has provided a host of enemies to keep these rapidly breeding rodents in check. Carnivorous animals, both large and small, prey constantly on them, but unfortunately the majority of these animals, when in the vicinity of man, attack and destroy his stock animals and poultry, and have to be exterminated. The destruction of these natural checks results in an increase of rats and mice with a correspondingly large amount of damage to produce, pasturage, and forests. Snakes prey largely on rats and mice, but many of these reptiles are venomous and cannot be tolerated in our neighbourhood.

Again we are obliged to invoke the services of the bird to save us. Hawks and owls are the principal enemies of the rapidly breeding rat and mouse tribe. The hawk by day and the owl by night wage a steady, unceasing war upon them. Without the hawk and owl, man would be in a sorry plight indeed. Yet man is so dominated by prejudice, false beliefs, and superstitions in regard to owls and hawks that he continues 


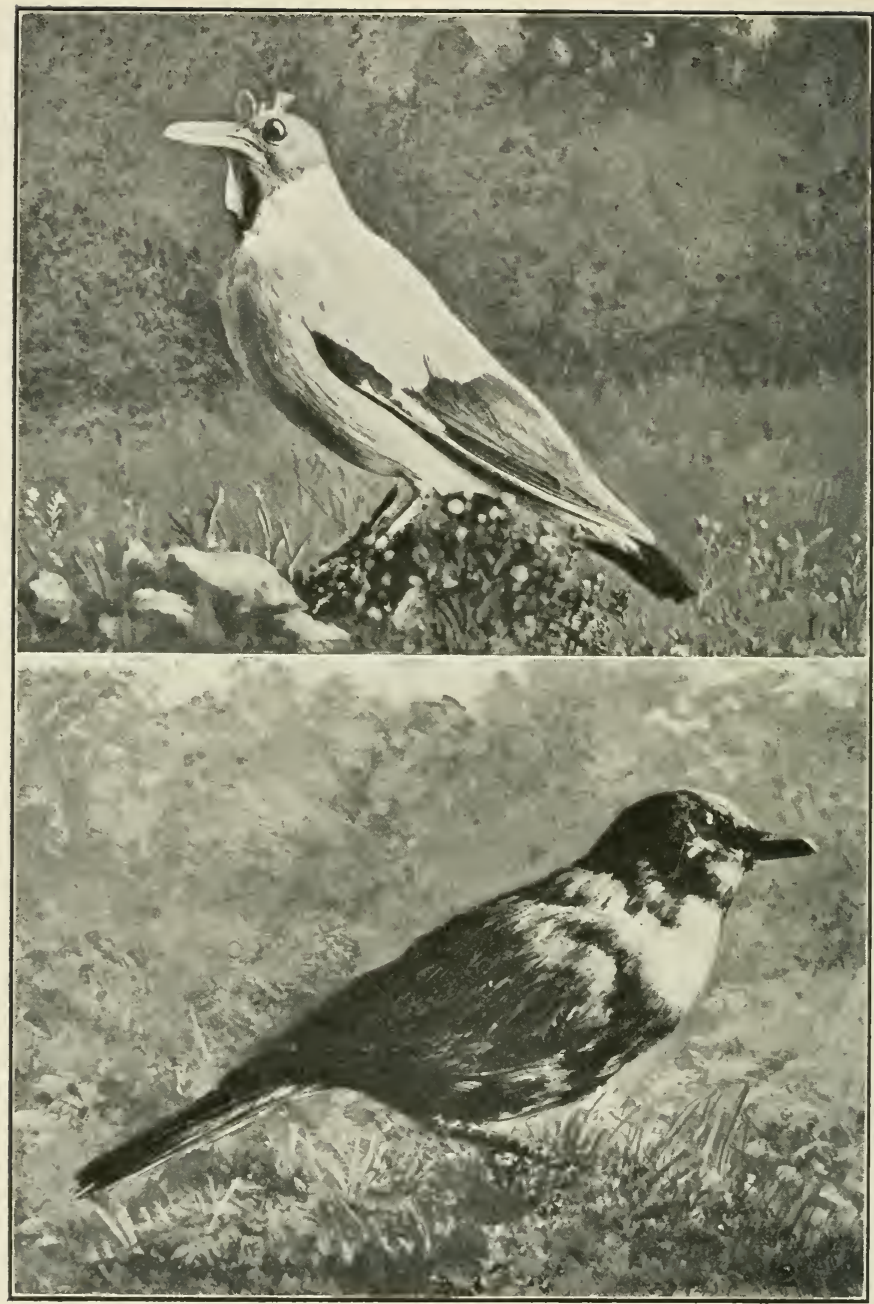

1. The Wattled Starling, or Little Locust Bird (Dilophus carunculatus). combines in great flocks and annihilates vast swarms of migratory locusts. When locusts are unobtainable it preys on grasshoppers and a variety of other destructive insects and their larvæ.

2. The Black-vented Glossy Starling (Lamprocolius melanogaster) confines itself to the thicker portions of the roast bush, and feeds on insects, berries, and wild fruits. 


\section{THE DESTRUCTIVE RODENT}

to persecute them relentlessly in the face of the unanimous testimony of ornithologists who have made a life-study of birds and their food. How can it be otherwise, however, when economic natural history is not taught in schools, and the people pass their leisure time in reading books of fiction only?

A female rat is capable of producing as many as six litters a year, and from eight to ten in a litter. The progeny begin breeding when half grown. So rapidly do they multiply, that from a single pair a large city or a farm miles in extent would, in a few years, be overrun with a countless horde of these destructive rodents.

Thrice fortunate it is for man that he can command the service of the hawk and the owl in his fight for life against the rat and mouse tribe. Without the help rendered by owls and hawks these rodents would eat him out of house and home.

We possess a very reliable means of finding out what kind of diet the owl is most partial to. These birds regurgitate or vomit pellets consisting of the indigestible portion of the bodies of their prey, such as the hair and bones.

A pair of barn owls (Strix flammea maculata), or dood-vogel, reared their offspring in the loft of an old outbuilding. After the young were reared and had flown away I examined the nest and found in the regurgitated pellets the skulls of 698 mice and rats of various species. Another pair inhabited a large cavity in an old tree trunk, and after two broods of young had been reared I examined the hole and found 
pellets containing the skulls or portions of skulls of I,089 mice, and those of $7 \mathrm{I}$ rats, as well as the remains of a variety of insects. 'These results were confirmed by over fifty similar observations at various times and places.

Although this bird wages nightly warfare on the mice which infest the farmer's barns, stacks, and fields, it is given no mercy. Some farmers, believing it destroys poultry or game, shoot it down at sight; others kill it or allow their children or employees to do so through sheer love of taking life. There is a widespread superstition amongst uneducated country people that if this bird settles on the roof of a house and hoots, one of the members of the household is sure to die. Impelled by this stupid belief these eminently valuable birds are remorselessly killed or driven from the neighbourhood.

If men regard knowledge as a weariness of the flesh, and neglect to acquire it, they pay dearly for their ignorance, and will continue so to suffer until they awaken from their lethargy.

There are two distinct classes of owls-the large eagle owls and those of smaller size. 'The smaller owls, of which there are several species in South Africa, prey chiefly on mice and rats. When this form of prey is scarce, the larger of the insects which are active at night are captured and eaten. The eagle owls, so-called because of their large size, are equally valuable to man, for 90 per cent. of their diet consists of rats and mice. Farmers are far too apt to condemn this extremely valuable bird because it 


\section{THE DESTRUC'TIVE, RODENT}

sometimes kills poultry. The enlightened, progressive farmer constructs vermin-proof enclosures in which his fowls can roost at night. 'The lazy, easy-going type prefer to let the poultry sleep in trees, or anywhere; and when an eagle owl, driven to desperation by hunger, attacks and kills a fowl, the owner's ire is aroused, and all owls are shot on sight ever afterwards. Even should an eagle owl be known to take fowls in this way it would be far more economical for the farmer to make a proper roosting enclosure for his fowls than to kill that owl.

Should an owl only succeed in killing one rat every night it would render great service to man, for about half of the 365 rats killed annually for a period of twenty-five to thirty years and longer would be females, each of which would have produced half a dozen litters of eight to ten in a litter annually.

Now and then an eagle owl succeeds in killing a hare. Knowing this, the sportsman regards this bird as a foe. What is the life of an occasional hare against the swarms of rats and mice slain by this magnificent bird? The hare is a destructive rodent and a positive pest devoid of any economic value. The bird is often accused of being destructive to game birds, particularly partridges and pheasants. This is not so. 'These birds hide away so effectually at night that it is impossible for the owl to see them. It must be borne in mind that owls hunt for their prey by night only, and in doing so they invariably skim noiselessly over the land and drop down upon their victims before they can find a refuge. The mission of the owl is to 
keep nocturnal rodents in check; and the hawk preys upon those which come forth to feed by day.

The worst enemy of the game bird is the rat. This rodent, particularly the bold brown rat, destroys the eggs, chicks, and even adult birds. But so silently and secretly does it work, that men do not perceive its fearful ravages, but, finding the remains of a young hare or game bird on occasion in the pellets or crops of eagle owls, they slay these birds which are the saviours of game birds, crops, and pasturage. Truly man has eyes, but he sees not. In the course of a year an eagle owl may kill two or three partridges which were unwise enough to venture from their retreats before the owls had retired to rest at break of day. One rat will kill the sitting bird and ravage a nest containing eight to a dozen eggs in a single night. Ascending the trees, and guided by its keen sense of smell, it preys upon the eggs and helpless young of highly valuable insect-eating birds; or, having a fancy for grain, it visits the standing crops or barns, and feasts to repletion.

An owl kills a minimum of $\mathrm{I}, 0 \circ \mathrm{rats}$ and mice a year, and indirectly saves great numbers of valuable birds and produce. The young of both owls and hawks remain a long time in the nest and consume great quantities of food, which consists almost entirely of destructive rodents captured by the parents.

I have seen eagle owls mobbed by small birds during the daytime, and never on any occasion did they attempt to retaliate. Even when in the deep, dark recesses of the forests they did not make any 


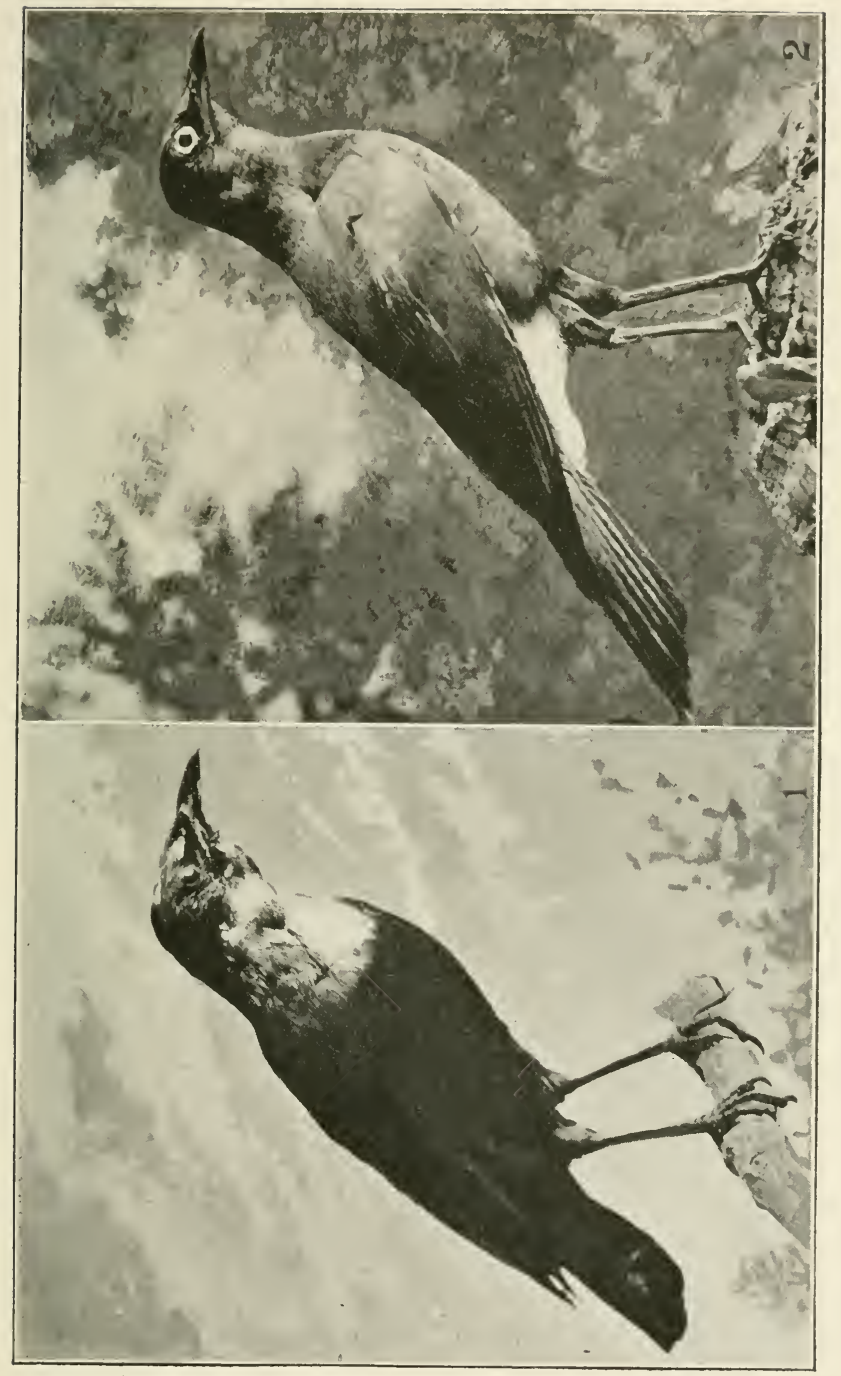

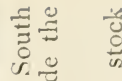

‡.

芯芯

焉 $=$ क

- 0 co

कै हैं

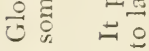

पढ

.

๘.

क.

ปूँ

ठㄹ

๘ँ

o $=$ के

$\rightleftarrows$ E

छ

केष्ठ ज्ञ

¿

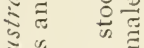

ป ठ

ऽ

$\approx . \Xi \breve{~}$

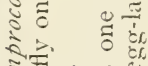

푤. क

넌

啊 $\approx$

$\Xi \pm 0$.

盯

ก.

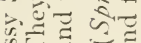

${ }_{0}^{0}=$ उ

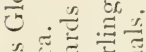

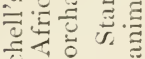

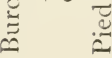

- -i 
attempts to seize their tormentors, although within reach of bill and claw. I have examined the cast-up pellets of the three species of South African eagle owls at various times and seasons, and the results furnished overwhelming proof that these birds render invaluable service to man by eating rats and mice. The farmer who destroys or allows others to destroy any species of owl on his farm is doing himself, his neighbours, and the State a serious mischief.

The spotted eagle owl (Bubo maculosus) is the species which renders the South African farmer the greatest service; the other two are shyer birds and flee from the haunts of man, having learned by bitter experience how treacherous and untrustworthy he is.

The spotted eagle owl is one of the nocturnal keepers of our lands and plantations, and the poaching rats and mice lead hard and perilous lives when these owls are abroad.

Unfortunately, however, the spotted eagle owl's cry to his mate is a mournful hoot, or rather succession of hoots. This is thought by ignorant people to be an augury of death to a member of the household, and, like its cousin the barn owl, the spotted eagle owl is sacrificed at the altar of superstition.

The barbarous, inhuman cruelties inflicted upon God's creatures on this beautiful world by people who are under the influence of stupid superstitious beliefs is simply unthinkable. I have heard men boast of their fiendish practices against our friend the owl. Through ignorance of the first principles of hygiene, a child died, and the superstitious father, 
having heard the hoot of an owl some hours prior to the boy's decease, concluded the bird was in some way responsible. A relentless war on the owls followed. So dominated by senseless superstition was he, that when an owl fell winged, he, with a curse, left it to die an agonising, lingering death.

The owl is the only bird which preys on nocturnal rodents, and the night jar on night-flying insects; consequently every effort, both educational and coercive, should be employed to protect these birds from molestation. A few species of ordinary diurnal birds might be exterminated, and other species would do their work. But should the owl and night jar be annihilated, there are no others to fill the gaps. 'The principal diet of hawks consists of rats and mice. They also devour prodigious numbers of locusts, grasshoppers, and other vegetation-eating creatures.

When omnivorous small birds increase abnormally in numbers, they are apt to become a pest, owing to their natural diet of insects and seeds of weeds and grasses not being sufficient for their needs. Hawks are Nature's agents in preventing small birds breeding too rapidly, and also in checking disease and eliminating the physically unfit; for, naturally, a sick or inactive bird falls an easy prey to a hawk.

Should hawks become too numerous, then it is justifiable for man to reduce their numbers; but this should be done only after mature consideration and observation. The larger species of hawks sometimes become chicken thieves, and it is then necessary to destroy them. But man is certainly not justified in 
raising his hand against the entire hawk tribe because of the predatory acts of a few hawks. Kill the offenders certainly, but leave the others alone.

What of the quails and partridges taken by hawks? you ask. The number of these birds slain by hawks is very few in comparison to the rats, mice, and insects devoured. What matters an occasional quail, partridge, pheasant, or rail to the saving of crops, plantations, orchards, and pasturage from the ravenous hosts of rats, mice, locusts, and grasshoppers?

The governors of one of the States of America many years ago, persuaded by the farmers that hawks and owls were harmful to man, actually passed an Act providing a bounty of fifty cents each for every hawk and owl killed within the boundaries of the State. In addition to this sum another twenty cents were given as fee to the notary taking the affidavit. In two years the State paid out 100,0०० dollars in fees and bounties. This mad slaughter of hawks and owls resulted in a rapid increase of rats, mice, and other small rodents, culminating in an actual loss to farmers in grain and other crops of $4,850,000$ dollars. This merely represented the loss immediately following the destruction of the chief natural enemies of small rodents. Many millions more of dollars were lost before the balance of Nature was restored. And yet man still prefers to muddle along, making more or less blind hits and misses instead of calling in and profiting by the advice of his men of science.

In Montana a similar stupid Act was passed which also brought upon those foolhardy people an appalling 


\section{THE DESTRUCTIVE RODEN'T}

plague of rats. Then the governing body hastily repealed the Act and passed another, offering bounties for the destruction of rats, mice, and other small rodents; but the sums paid out were so great that the legislature was hastily summoned, and the Act was repealed because the State could not afford this financial drain which threatened to render it bankrupt.

Later, Nevada, California, Wyoming, Utah, and several other States were also smitten as heavily as Pennsylvania and Montana for their sins in slaying their friends the hawks and owls-allies which were performing services worth millions sterling annually and asking nothing in return, except an occasional chicken when one of their kind was on the verge of starvation or which had a nestful of hungry youngsters, and the supply of rats and mice had temporarily proved insufficient for their needs.

Riding with a farmer one day, we saw a large hawk drop to the ground and rise with a partridge in its talons. My friend shot at it and missed, but the hawk dropped its prey. On examination it proved to be a coqui partridge, blind with chicken-pox.

During twenty-five years' museum experience I have examined the crops of a large number of hawks of various species. The predominating food was rats, mice, and grasshoppers. Only now and then the remains of birds were found. The crops often contained a curious assortment of creatures, chiefly locusts, grasshoppers, crickets, termites (white ants), and snakes. When locusts are abundant, hawks feed almost exclusively on them.

VOL. I. 


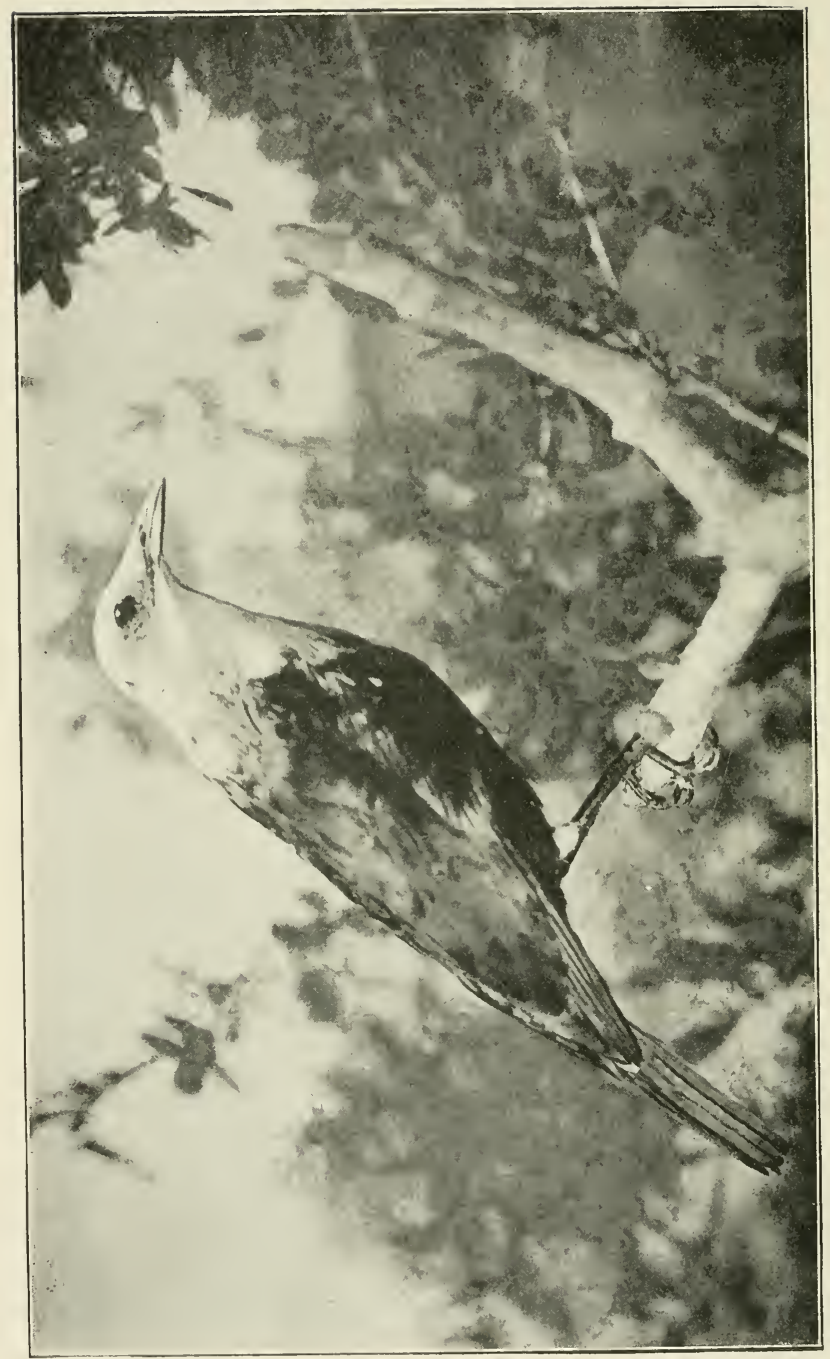

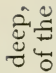

.

引.

$\circ 0$

ㄴ. I

है

응.

国

E-

म․ 동

t)

ว

क्ष 0 ह

잉

त.

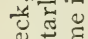

的

¿ 0

đ. $2 \frac{3}{3}$

ᄃ.

$\stackrel{2}{=} \frac{0}{\infty}$

ㄱ. 욜

프 ह

$\because \quad$

(5)

$\approx$ L

i:

จับ

.

है

को

¿

¿

रे है चु

¿

का 픙

焉焉

की 


\section{THE, DESTRUCTIVE, RODEN'T}

Hawks may be classed as highly beneficial to man, the larger hawks, such as the buzzards, much less so on account of their disposition to attack and kill poultry.

The eagles are not of much economic value to man, owing to their lamb and poultry destroying habits. They kill off large numbers of rats, but their smaller cousins the hawks, if left in peace, are capable of keeping these rodents in check.

In the past the eagle acted as a natural check on small antelopes, klip dassies, various rodent animals, such as hares, game birds, etc.; but such services are not now required, and the larger eagles will in time pass from the face of the earth.

Sir Boverton Redwood, speaking to the British Science Guild in I9I4, said: "It is estimated that the birds of Nebraska eat I70 cartloads of insects a day; that those of Massachusetts destroy 2I,000 bushels of insects daily; and that a single species of hawk saves the farmers of the Western States I 75,000 dollars a year by destroying grasshoppers and field mice. Yet millions of people wantonly kill birds that destroy injurious and disease-spreading insects."

The moral of these facts applies to South Africa.

"You slay them all! and wherefore? For the gain

Of a scant handful, more or less, of wheat,

Or rye, or barley, or some other grain

Scratched up at random by industrious feet

Searching for worm or weevil after rain!

Or a few cherries that are not so sweet

As are the songs these uninvited guests

Sing at their feast with comfortable breasts."

LONGFELLW. 


\section{BIRDS AND INSECTS}

The well-known wire-worm and cockchafer grubs are the larvæ of beetles. They live chiefly in cultivated soil for three to five years before changing into beetles. Meanwhile they are busy all the time devouring the roots of crops and useful pasturage plants. They attack all crops with the exception of mustard; and in South Africa they feed all the year round. We have no chemical or other agent by which we can kill these grubs. A host of species of birds feed on wire-worms, cut-worms, and cockchafer grubs. Amongst others they are eagerly sought after by rooks, hoopoes, starlings, thrushes, larks, plovers, partridges, pheasants, quails, and guinea-fowls. When the grubs are turned up by the harrow, plough, or spade, a host of other species of birds pounce upon and devour them.

It has to be remembered in cases of stomach examination that soft animal food is digested with great rapidity and leaves few traces, whereas grain and seed remain in evidence a much longer time.

The army moth is another dreaded South African scourge. A vast army of moths settle by night upon the succulent pasturage and lay their eggs. Presently an uncountable host of caterpillars emerge from the eggs and eat off the grass and crops as effectually as if they had been burned by fire. They travel in a vast army, eating every green blade and leaf before them.

The night jar and insectivorous bats prey upon I 80 
the moths by night, and birds assemble from the surrounding country and fall upon the caterpillars by day.

Flocks of starlings attack and devour them in great quantities. Even the seed-eating birds lend a hand and dispose of hosts of them. Yet I have seen pothunting boys and grown men go out and shoot a double charge of shot into a flock of starlings engaged in this magnificent work. The dead and crippled birds are gathered up; numbers of wounded escape to die miserably, and the flock departs terror stricken to another part of the country.

There are hundreds of species of weevils. They are equally destructive in both the adult beetle and larvæ or grub stage. The larvæ attack and voraciously feed on peas, beans, and all kinds of grain, and the beetles devour green crops, fruit trees, garden flowers, and even invade the conservatories. They often strip a tree bare of its buds, flowers, and shoots. When birds assemble to feed on them, the untrained observer declares the guilty parties are the birds, and forthwith a brutal war of extermination is waged on our allies.

In a single season a fruit grower of my acquaintance lost $f .700$ from the ravages of weevils.

I have found weevils and their larvæ, mostly the former, in the stomachs of large numbers of South African birds. Often the stomach contents were 90 per cent. weevils.

Starlings prey largely on them, and they are right royally reinforced by thrushes, chats, sparrows, finches, 


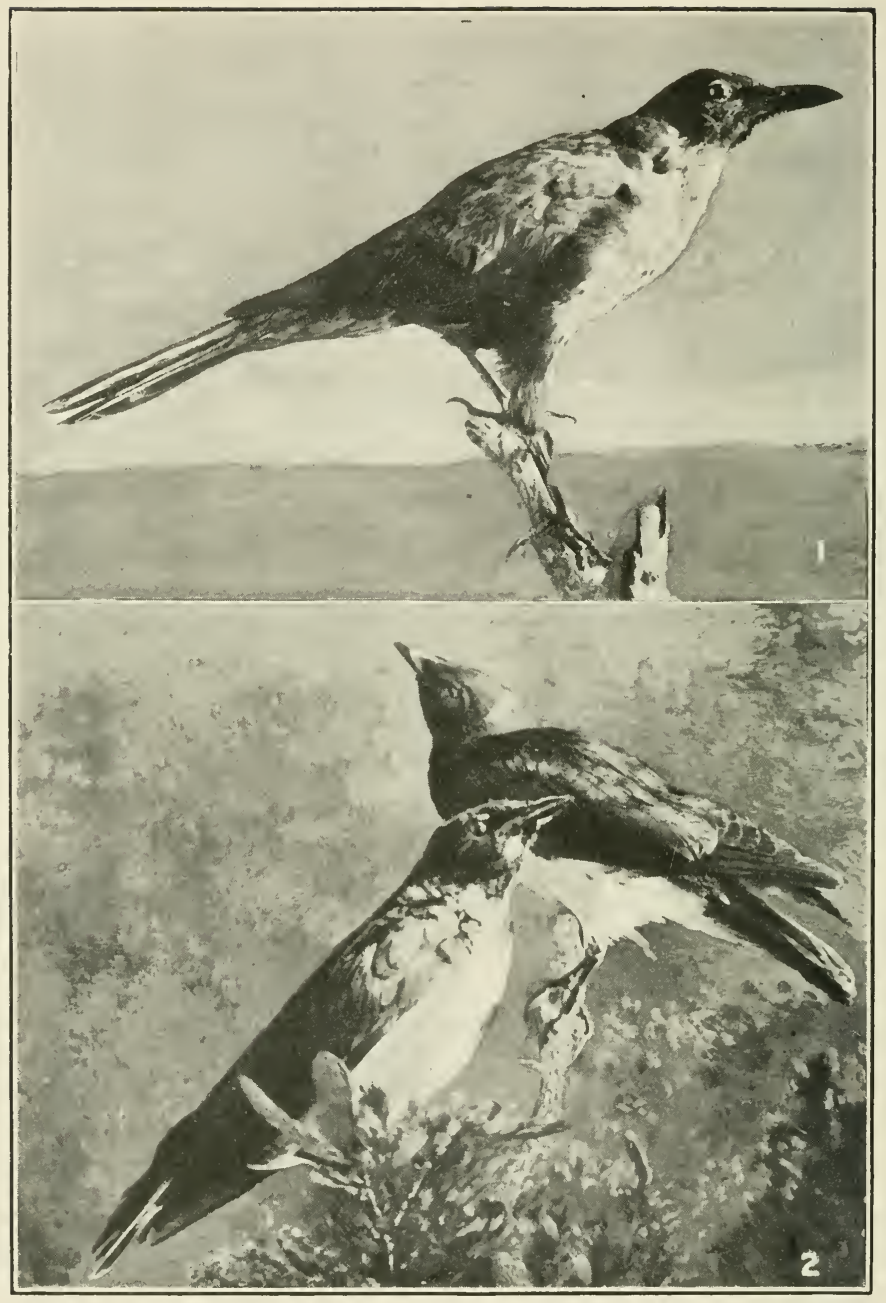

1. The Red-wing Starling, Spreeuw or Rooivlerk (Amydrus morio), is a pest to the fruit grower. When no fruit is available, its diet consists of insects and wild berries.

2. Verreaux's Glossy Starling (Pholidanges verreauxi). In the sun this marvellously beautiful bird glitters like burnished copper, with purple and violet reflections. 
white eyes, orioles, weavers, wagtails, sun birds, tits, shrikes, bulbuls, and fly-catchers.

The aphides, otherwise known as plant lice or green fly, do extensive damage to both cultivated and wild plants.

In England the damage done to the hop fields in a single season amounted to $f . \mathrm{I}, 750,000$, with an additional expenditure of $f, 200,000$ to overcome the plague.

In South Africa the damage by insects is great, and goes on from year to year, varying with the number of bird enemies there happens to be in the locality. With but very few exceptions the smaller birds prey upon these rapidly breeding plant lice. Even the little seed-eating birds, such as wax-bills, sparrows, finches, and weavers, eat vast numbers.

Scale insects infest trees and plants to an alarming degree. Their chief bird enemies are the woodpeckers, tree-creepers, tits, and white eyes.

Caterpillars are the larvæ of butterflies and moths. Of the many hundreds of species of birds in South Africa, there are not more than fifty species which do not feed more or less on them when the opportunity presents itself. With but very few exceptions the smaller birds feed their young on soft-bodied insects. I have found by actual examination that 90 per cent. of the contents of the nestlings' stomachs consists of small caterpillars.

Moths, gnats, and multitudes of other kinds of flying insects are eaten by swifts, swallows, martins, fly-catchers, night jars, wagtails, warblers, and an army of other species of birds in a minor degree. 


\section{NATURAL HISTORY OF SOUTH AFRICA}

The majority of species of moths and butterflies lay their eggs in clusters on trees or other vegetation. The much despised Cape sparrow and other seedeating birds, as well as a hundred other species of small birds, are particularly fond of these eggs and the newly hatched larvæ, and the uninformed observer, seeing them thus employed on his fruit or other trees, hastily concludes they are devouring the young shoots, buds, flowers, or fruit. Moths hide away by day and issue forth at night to lay their eggs. It is the business of birds to know where to search for these inveterate enemies of man, and they perform their work well and faithfully.

The little white eye (Zosterops), which associates in small flocks of a dozen and more, makes a thoroughly systematic search for the eggs and young larvæ on trees and shrubs, and the small amount of damage it causes to soft, ripe fruit in an orchard does not amount to more than Io per cent. of the good it accomplishes in clearing the orchard of a number of insect pests, including the destructive fruit fly, unless, of course, its numbers are abnormal.

On turning over the pages of a standard work on economic entomology, the mind is bewildered and staggered at the host of species of insects and allied forms of life which prey upon man, his domestic animals, and the produce of his lands.

Man is fighting against his insect enemies for his very existence, and it is only by utilising the services of trained entomologists, ornithologists, naturalists, and other men of science that he will ultimately emerge 
victorious. At present the insect hosts are the strongest allies of the Angel of Death. They sow disease and death broadcast in his pathway through life. The pitfalls they cause are so numerous and well concealed that comparatively few people ultimately escape and die peacefully of old age as Nature intends, in order to gain the fullest earth experiences before entering the next phase of life in the beyond. The insect armies attack us at all points. They not only sow deadly diseases amongst us and our domestic animals; they ravage and cripple us in a thousand other ways. Our food supplies are reduced alarmingly by them. They attack and destroy our timber, our dwellings, our furniture, clothing, and even that poisonous weed, tobacco. The nicotine of tobacco is one of the most powerful poisons known to science, yet there are certain beetles which thrive on prepared tobacco leaves.

While our enemies the insects are slaying us and our stock and cutting off our food supplies, we continue to quarrel and wrangle among ourselves and strive for place and power; or live our little selfish lives, snatching impotently at the will-o'-the-wisps of so-called pleasure instead of combining and utilising our resources and the trained minds of our men of science to present a solid front against this terrible enemy which is eating into our vitals.

Nay, more! We persecute and destroy our feathered allies which God in His wisdom has given us to help fight our battles. If, perchance, we do not actively persecute our bird friends and helpers, 


\section{NA'TURAL HISTORY OF SOU'TH AFRICA}

we remain stupidly indifferent to the effective striking power of this ally in our unending war on insects.

The average layman does not, as a general rule, observe accurately or reason overmuch on his observations. It is good enough for him to see a bird feeding on his fruit, his grain, or his chickens to forthwith declare war on all birds of the same species. Many farmers can only distinguish a few species out of a hundred or more. They class them merely as " small birds"; or, if belonging to the great bird of prey family, they are "hawks" or "eagles." There are in South Africa a few birds whose destructiveness is so apparent that they stand condemned. An instance in point is the coly or muis vogel (Colius). With the exception of this species and a few others, it is essential to have expert analysis of the contents of crops and stomachs at different periods of the year before pronouncing judgment on a bird. This work should be conducted in the laboratory and in the field.

It is not only the suffering of the bird we are trying to prevent; it is the moral degradation of the person who causes the suffering.

"And a town meeting was convened straightway

To set a price upon the guilty heads Of these marauders, who in lieu of pay

Levied blackmail upon the garden beds And corn-fields, and beheld without dismay

'The awful scarecrow, with his fluttering shreds; 'The skeleton that waited at their feast,

Whereby their sinful pleasure was increased."

LONGFELLOW. 


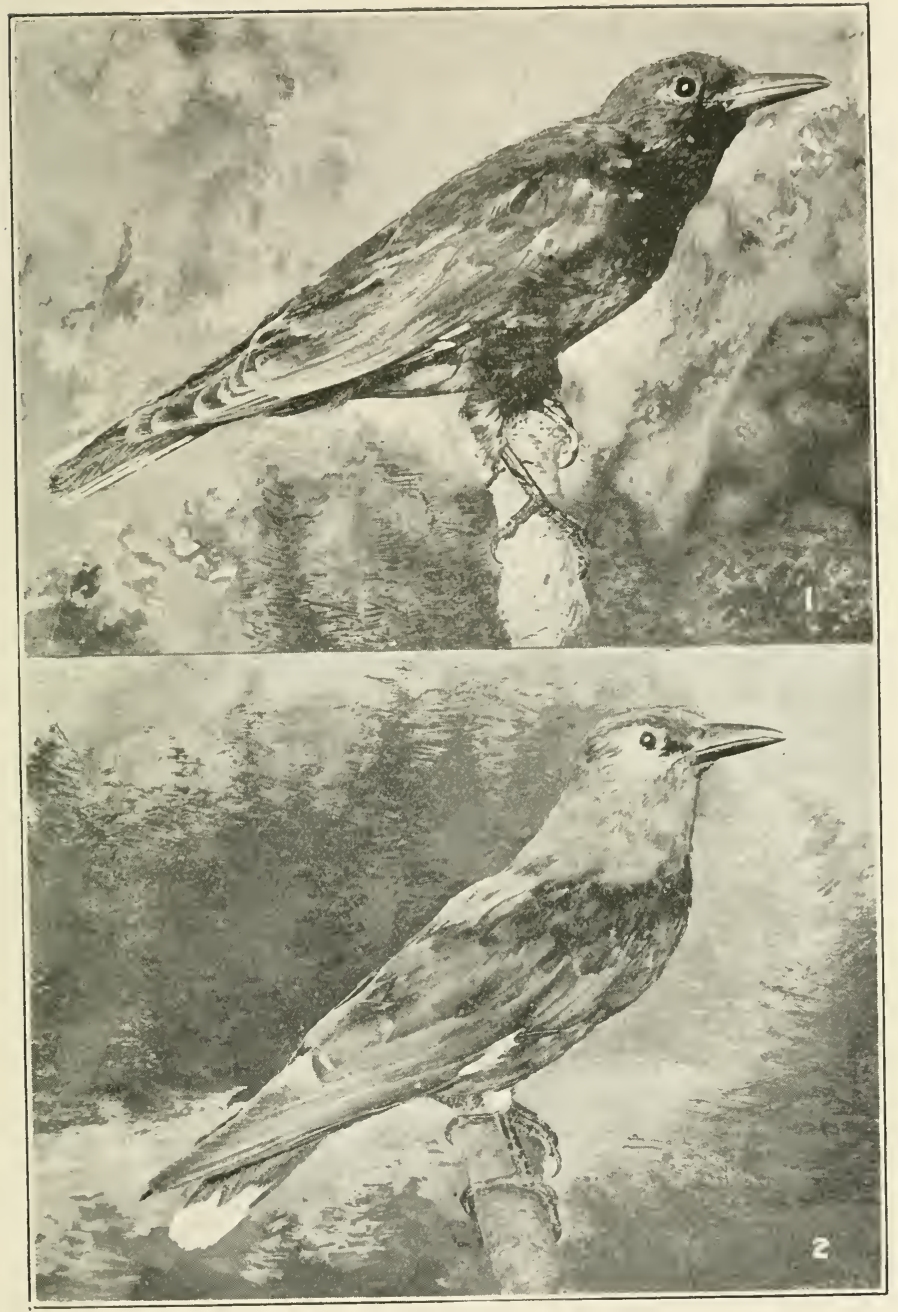

1. Black-headed Oriole (Oriolus larvatus).

2. Golden Oriole (Oriolus galbula).

The former is common in the bush-veld and forests of South Africa at all times of the year. The latter migrates during the spring into South Africa from Europe, Asia, and Northern Africa. Both species are greedy devourers of insects and their larvæ. They are both efficient policemen of the forests. 
As man's knowledge of the great part played by birds in safeguarding the forests, pasturage, cultivated crops, and orchards increases, so will his indifference to the welfare of these indispensable allies decrease. So, too, will he eagerly seek by every means in his power to conserve bird life when he realises more fully how loyally birds are aiding him in his struggle against insect-borne diseases which ravage his race and his stock animals. What better way have we of imparting this knowledge than by teaching economic natural history in schools? One wonders when men will cease to struggle for place, power, and wealth, and devote their time and energies to the betterment of others of their race. If we really want to see South Africa prosper, and if we desire to make it possible for our children and our children's children to settle down and make their living in the country, two outstanding barriers must be removed:-

I. The diseases which attack man, his stock animals and crops, must be attacked and conquered.

2. Economic natural history must be studied in all its branches, and not only taught to school children ; but measures of the most thorough and practical kind must be taken to protect the natural enemies of the hosts of foes which assail us, our animals, and our products.

A teacher, after twenty years' experience, said : " Nothing ever helped me so much to manage boys as teaching kindness to animals." 


\section{NESTLING BIRDS AND THEIR FOOD}

\section{NESTLING BIRDS AND THEIR FOOD}

Young birds grow rapidly, and consequently they must have an abundance of food. When there is a shortage of provender, the strongest bird in the nest gets the greater bulk of the food, and its less robust brothers and sisters slowly weaken and die.

There are many tragedies in the family life of birds. The weather may be cold and rainy, and insects hard to find. The parents in their desperate eagerness to feed their hungry child-

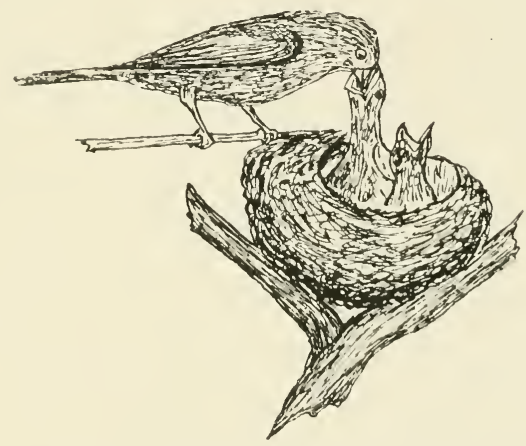

A Nestling Bird will eat its own weight of grubs in twenty-four hours. ren neglect their own needs, and one or both perish. In the latter instance, of course, the entire brood inevitably dies. When one parent succumbs or is slain by an unthinking boy, the other makes heroic efforts to provide a sufficiency of food for the family; but notwithstanding its struggles, the majority of the brood wilt and perish.

Young birds remain in the nest from little over a week to several months, according to the species. The average is from two weeks to a month. The majority of birds, after leaving the nest, continue to 
be fed by the parents until they are fully fledged and have learned how to find and capture their own food. The young of the secretary bird remain in the nest for nearly six months until fully feathered, while those of the English sparrow are out in about a week.

A nestling bird will eat its own weight of food in twenty-four hours. Some kinds eat double their weight in the same period. The young of the smaller species of birds, such, for instance, as robins, warblers, thrushes, etc., will eat I 50 caterpillars, each I inch long, in twelve hours, and then will be greedy for more. A brood of birds consists in most instances of from three to five youngsters. We will take four as the average. If one young bird eats 150 caterpillars and other kinds of insect pests in the course of one day, the four will dispose of 600 daily. Add to this another ro० for the parents' sustenance, and we have 700 insect pests destroyed daily for about two months. Therefore from the day the young hatch until they are able to fend for themselves, a single family of birds will destroy 42,000 insects. If these are true insectivorous birds they will continue their daily war on our insect enemies. Should they be of the seed-eating kind, they will also continue to feed largely on various forms of insects and allied noxious kinds of life, although their staple food will consist of seeds. It consequently rests with the individual farmer to use his discretion. If the birds are attacking his corn in phenomenal numbers he may be compelled to reduce them to normal limits. If they, however, are not too numerous it will pay him infinitely better to hire 
boys to patrol his corn lands when his grain is ripening and until it is reaped and stored.

The young of game birds are active from birth, and follow the mother after the manner of domestic chicks. The parent may have a flock of as many as fifteen or even more, as in the case of the guinea-fowl, partridge, and quail. The number of "white ants,"

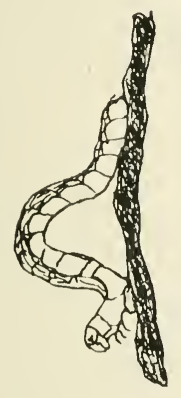

The Looper Caterpillar is picked off the twigs by the parent bircls and fed to their babies.

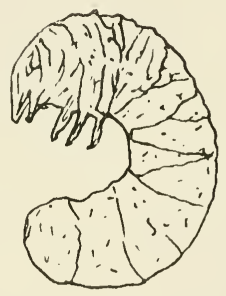

The Bustard, the Partridge, and other ground birds dig the larve of beetles out of the ground and devour them.

insects, their larvæ, and eggs which are devoured by so large a brood of hungry youngsters can easily be imagined. The young of game birds grow at about the same rate as the young of farmyard fowls. They breed during the spring and summer seasons when insect pests are at their zenith of destructiveness, and yet, notwithstanding the incalculable services rendered, we shoot them down for "sport" and the pot. I have watched parent birds visiting their young with insect food, and on an average small birds, such as 


\section{NATURAL HISTORY OF SOUTH AFRICA}

thrushes, starlings, weavers, and warblers, brought food I 50 times in a day of sixteen hours. On calm, warm, cloudy days, when insects were especially active, the parents visited the nest as often as 320 times.

An examination of the crops of the young revealed the fact that for every beneficial insect there were ninetyfive noxious ones. It is by no means good enough to

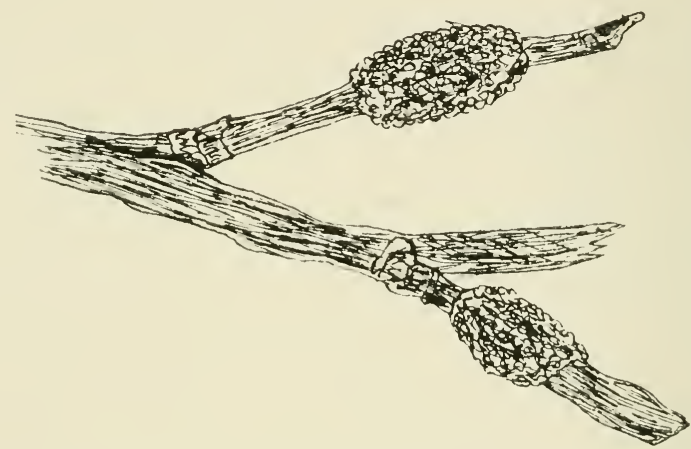

The masses of Insects' Eggs on twigs are picked oft and eaten by birds.

strictly preserve certain kinds of birds and leave others without any measure of protection, for the reason that each species of bird has its likes and dislikes in regard to food. Some birds feed their young on certain species of insects which another bird will pass by as unpalatable. For instance, I have observed the fiskal fly-catcher (Sigelus silens) feed its young on a certain hairy caterpillar that no other bird would touch. It will therefore be realised that it is not sufficient to protect the purely insectivorous birds only. An army is composed of many regiments, and each has its 


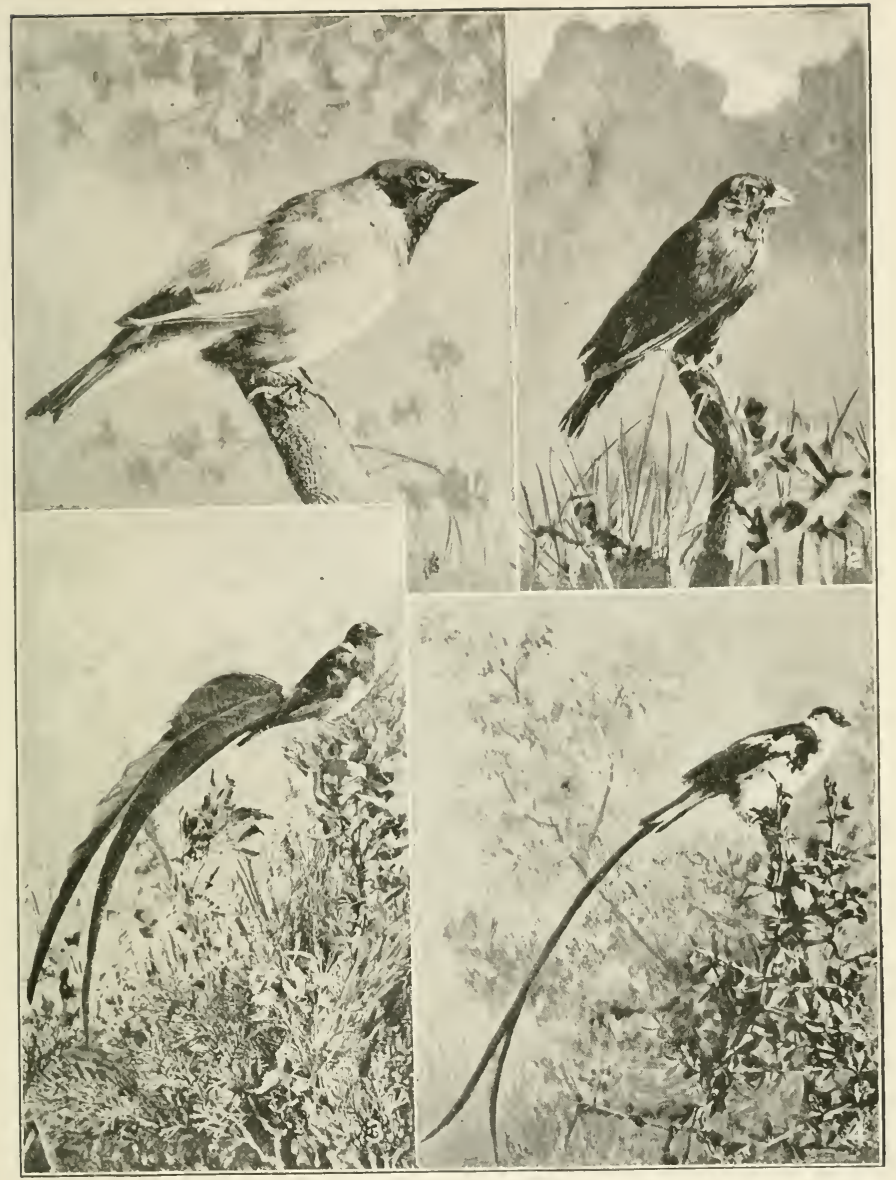

1. Masked Weaver Bird (Hyphantornis velatus). Weaver birds subsist largely on insects during the summer, and feed their young on them. During the winter months they live mostly on grain, and seeds of grasses and weeds.

2. Black Widow Finch (Iypochera funerea) of the eastern side of South Africa from Natal to the Niger.

3. Paradise Widow Bird (Vidua paradisea). Male in summer plumage.

4. Pin-tailed Widow Bird (Vidua principalis) in nuptial dress. He loves to flit in zigzag fashion over and around the lady of his choice.

VOL. I. 
special duties to perform in war. So it is with the various regiments (species) of birds in their endless war on the insect army. During the time of the year when their services are in special request, birds are most active in their war of extermination of the insect hosts. Yet we stupidly admire the feathers of wild birds in ladies' hats, and encourage our boys to collect birds' eggs. A farmer, whose son or Kafir employee robs a nest of its contents or kills a pair of breeding birds, leaves unslain at least 20,000 insect pests which rapidly mature on his succulent crops. Half of these are females. In a few days after their emergence from the chrysalis each of these deposits from 500 to 10,000 eggs on his crops, pasturage, and trees. The eggs hatch in a few hours or days, and a host of caterpillars emerge to begin feeding voraciously. Thus within a period of two months the destruction of a single pair of breeding birds, their eggs, or young, results in an active ravening army of more than a million caterpillars or other forms of insect larvæ. Verily, I say, we have eyes, but we see not; ears, but we hear not; brains, but we reason not. The house fly, the blood-sucking fly, and the mosquito sow disease and death broadcast amongst us and our stock animals, yet we persecute the birds which destroy these flies. The wagtail, the fly-catcher, the swallow, swift, and martin devour flies and mosquitoes wholesale; we calmly stand by while our boys and the coloured children destroy these eminently useful birds' nests or rob them of their contents.

Reckoning the time it takes for a bird to digest 


\section{NESTLING BIRDS AND THEIR FOOD}

flies, I worked it out, and have ascertained that a single fly-catcher, wagtail, swallow, or martin will dispose of from 200 to 300 flies in a single day. This

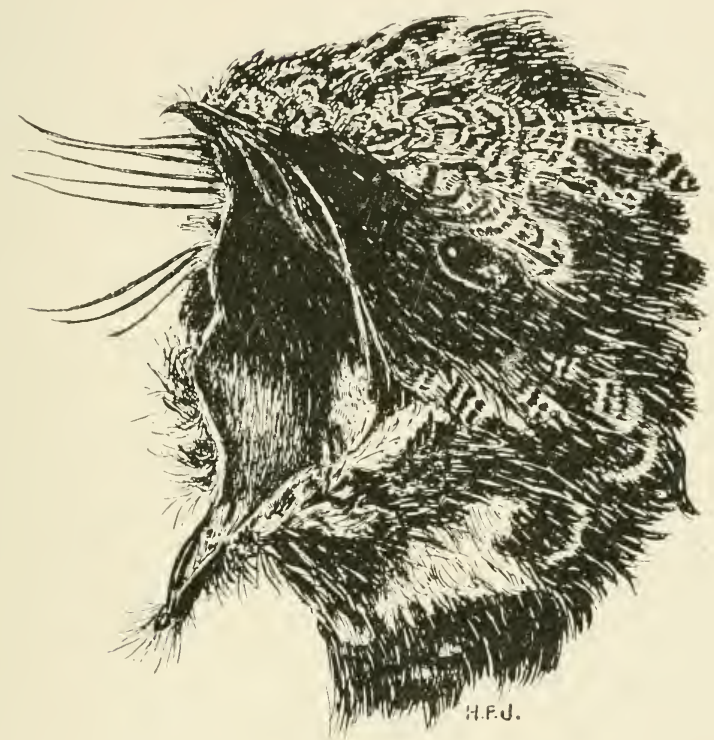

The Gape of the Night Jar. This bird hawks its prey on the wing at night. With a single snap it shears off the wings of a moth and swallows its egg-laden body.

The night jar is provided with a wide gape for capturing insects in the air.

is from a study of the stomach contents at various periods of the daylight hours. I have watched flycatchers at work feeding their young, and they have made as many as 450 journeys to their nest in the course of a day with food for their young. Half these flies are females. A female house fly lays I 20 eggs 
at a time, and the entire life cycle from egg to grub and chrysalis and the emergence of a full-grown fly is only a fortnight; therefore every female fly will produce $\mathrm{I} 20$ more flies in a little over two weeks from the day she emerges from the chrysalis. If a female fly escapes destruction in the spring, and if allowed to breed unchecked, then the progeny of that single fly will amount to something like $6,488,560,000,000$ before the chills of winter appear. The familiar wagtail, which loves to dwell in cities and villages and around homesteads, feeds its young largely on flies, their grubs, and chrysalides, and yet we permit our children to rob its nest or murder it with a catapult or air-gun. We rear cats because we are too "tender hearted" and sentimental to painlessly kill them when born. We think we are doing a kindness when we give these kittens away. We would pause and reflect if we knew that the great majority of these kittens grew up into hungry, mangy cats, whose chief diet consisted of our allies the birds.

I have watched the nests of warblers, fly-catchers, weavers, larks, starlings, sun birds, and numbers of others for an hour at a time during varying periods of the day. From these observations it was shown the parents brought insect food to the young about twenty times an hour. Sometimes the number of visits were less, but as often as not they were over twenty. The parent birds often bring two, three, and often more caterpillars at a time; but, taking one as the average, and twelve working hours, we have a total of 240 
caterpillars and other destructive larvæ fed to a single brood of young birds daily.

The caterpillar, the cut-worm, wire-worm, other grubs, and the hundreds of other units which make up the legions of insect pests which strive with man for the possession of mother earth, work more or less unseen. On the contrary, the bird is visible to the dullest observer. Consequently the damage some birds do is glaringly noticeable, but invariably grossly exaggerated. Being unaware of the extent of the ravages of the hidden insect pests, man fails to realise that the services rendered by our feathered police and soldiers usually outweigh the damage some of them do by twenty or even fifty to one.

In every country throughout the world where birds have been systematically destroyed, or where no active measures have been taken for their preservation, the results have always been the same :-

I. Insect and vermin plagues.

2. Grave losses to crops of all kinds.

3. The impotence of man in checking the plagues.

4. Efforts to bring back the birds.

It is not unusual to find crops injured by insect pests to the extent of 25 to 50 per cent. Ponder it well. At least 25 per cent. of the country's crops, stock, timber, and other products goes into the stomachs of insects and their allies, while we callously permit the feathered enemies of these foes of the human race 


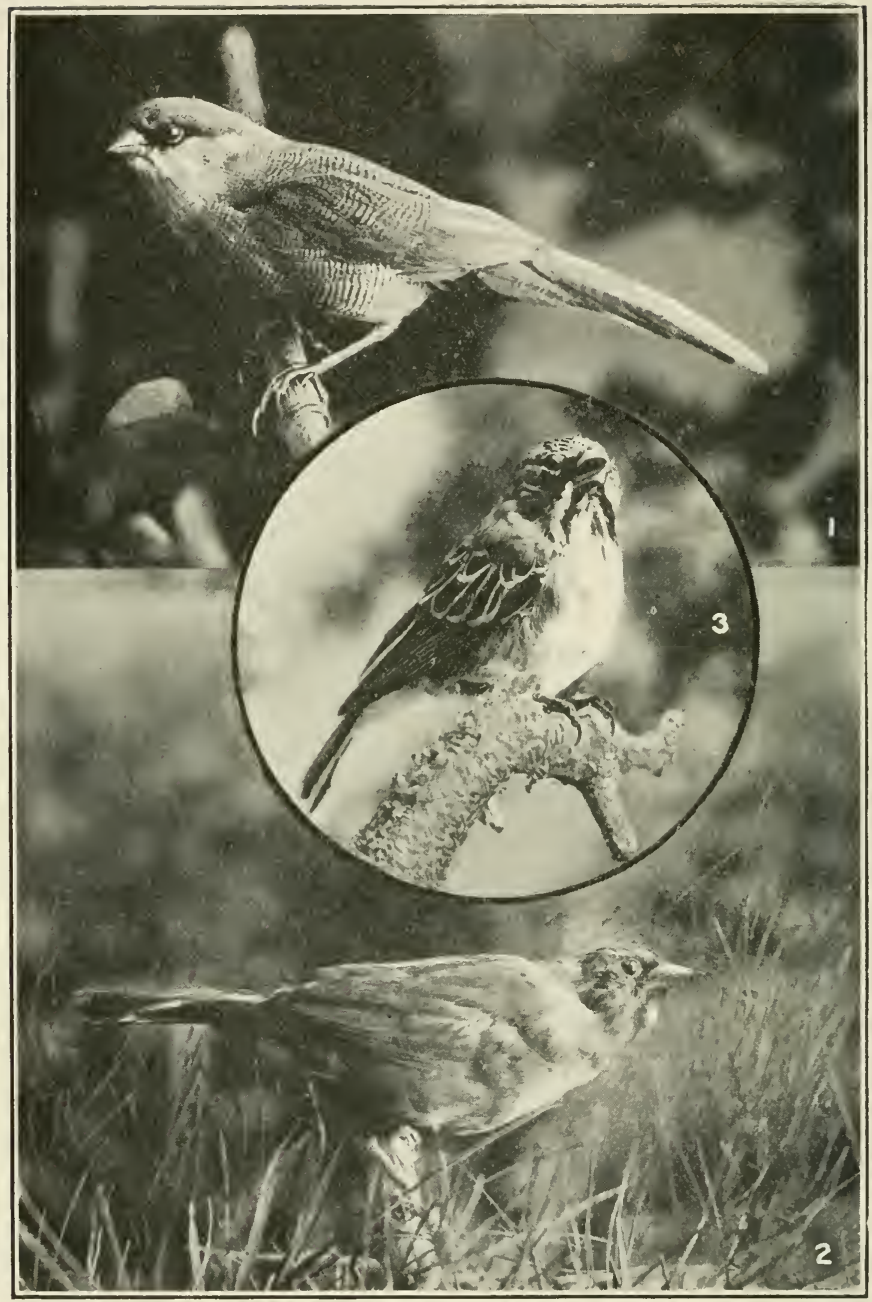

1. Common Waxbill, or Rooibeckie (Estrilda astrilda). A favourite cage bird.

2. South African Ruddy Waxbill, or Robin (Lagonosticta rubricata). The Waxbills feed on the seeds of weeds and grasses. They also eat a considerable number of insects and their eggs.

3. The dainty Scaly-feathered Weaver (Sporopipes squamifrons). 
to be murdered and otherwise persecuted. But! you exclaim, we in South Africa have placed the majority of our birds under the protection of the law ! Yes, so we have in some districts, but does the law afford them any protection? Is there any special machinery for the enforcement of the law? Are there special police whose duty it is to see that our feathered friends get the protection to which they are entitled? No! little or no effort is made to enforce the laws. The average policeman does not know one bird from another, and he cares less.

How blind we are. How stupidly short-sighted. If a man shoots a hare or a buck out of season, the sleuths of the law are keen on his track, and sooner or later run him to earth. Yet these animals are vermin. Let a man shoot a hare or a buck in the close season. What occurs? His neighbours at once raise a howl of indignation, and clamour furiously for the police to prosecute him. Those same people give their sons air-guns or shot-guns and applaud them when they shoot our bird allies. They encourage them to make collections of birds' eggs. They take no measures to prevent Kafir umfaans on their farms and estates from taking the plump young birds from their nests and eating them. This latter practice is general throughout South Africa. I know from twenty years' experience as a field naturalist. 


\section{HOW TO ENCOURAGE BIRDS TO BREED}

To encourage birds to breed on a farm, an estate, in a forest, or in parks, the first essential is to see to it that they are not persecuted in any way whatsoever. Then their habits require to be studied. Every species of bird has its likes and dislikes in regard to the situation and environment of its nest. Many species of eminently useful insectivorous birds build in dense thickets, others



The Wother Bird feeds her greedy children on soft caterpillars from the farmers' crops. in scrub, and so on. Knowing this, the wise farmer will leave patches of bush, scrub, bracken, and other forms of cover in various sheltered places on his farm.

When there is an insufficiency of natural cover, or when the trees are not suitable, as is the case in most orchards and timber plantations, it is necessary to make nesting boxes and attach them to the trees. These may be prepared from any kind of wood and covered with bark to make them look natural and inviting to the birds. The best way is to bore out sections of tree stems. Those species of birds which build saucer or cup-shaped nests will require little open boxes like trays. Those which build nests with a side entrance will at once be attracted to a nesting box with 
a side entrance near the bottom, at the middle, or close to the top. Nesting boxes may be placed about the homestead, in sheltered places, on outhouses, under the eaves, etc. Care should be taken to affix them in situations out of the reach of rats. It is highly desirable to encourage owls to breed, and suitable nesting boxes should always be provided for them. Rats and mice play appalling havoc to crops, other produce, and young plantations; and owls are their chief enemies. It is therefore a wise policy to take every possible measure to protect owls and encourage them to breed. The boxes should resemble cavities in the tree trunks, and ought to be placed high up on the stem or at the bases of the large branches.

Municipal and Government authorities would do well to put an abundance of nesting boxes high up on the trunks of trees in all public plantations to encourage owls, woodpeckers, and other feathered policemen of the forests to come and breed. Swallows and martins are of the utmost possible economic value. They may be encouraged to breed around the homestead by providing suitable covering from rain and wind under which they can build their nests of mud.

It is advisable to have nesting boxes placed in position a good while in advance of the nesting season. Birds begin building on the advent of spring, so the boxes ought to be put up during the winter to allow the birds to get accustomed to them. Fix the boxes in the most sheltered spot possible away from direct sunlight and strong wind and drifting rain. No nesting material should be put inside the boxes. A 
little sawdust or dry earth is all that is necessary. The boxes should be screwed very firmly to the tree trunk from 6 to Io feet above ground for small birds. See that they are out of reach of cats and tree snakes. Branches of the thorny mimosa nailed below or round the box will help to keep cats off.

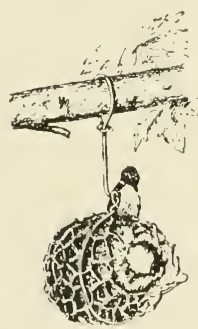

Crocheted Ball filled with cotton batting and feathers, with short lengths of yarn, string, and horse - hair added, for nest building.

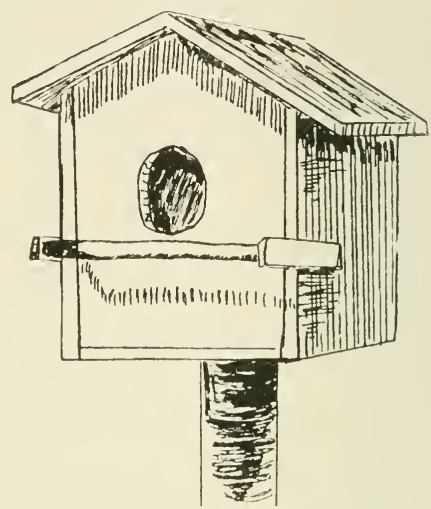

Nesting Boxes like this one may be placed on poles, trees, or under the eaves of houses.

The upper part of the box should incline slightly forward. Boxes ought not to be too near together, and the birds should not be disturbed while nesting. The boxes should vary in shape. Some birds prefer deep boxes, and others medium or shallow.

The tree-hole boxes are bored in the solid wood. The lids of closed nesting boxes should be hinged or screwed so that they may be easily opened for a yearly cleaning. 


\section{HOW TO ENCOURAGE BIRDS TO BREED}

Stray cats should be poisoned or shot, and a constant warfare waged on rats, as these canines and rodents play havoc with birds.

Apart from the economic aspect of the matter, people ought to take the greatest pleasure in preparing and putting up nesting boxes for birds, so that they may be encouraged to settle down and rear their families in the neighbourhood of homesteads. The presence of birds with their cheery song and happy, bright ways do much to lessen the feeling of solitude and loneliness of dwellers on farms. Any boy or man who is at all handy can easily make nesting boxes with little or no expense. The great essential is to make them after the manner of the actual nest. The outward appearance need not be imitated. For instance, birds which build open saucer-shaped nests will not rear their young in closed nesting boxes with a hole at the side; nor will those species of birds

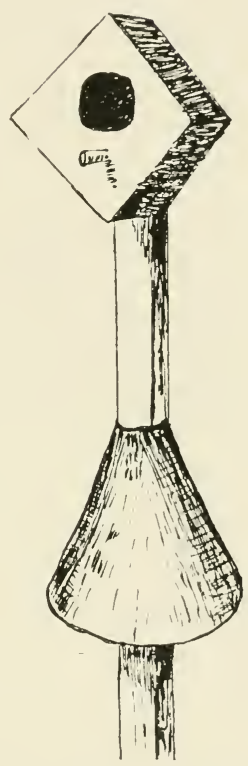

A Cat-Proof Nesting Box. The pole is surrounded by a funnel-s haped piece of zinc, inverted. which build domed nests take to open nesting boxes.

Gourds cut in half, and others left entire with a sufficiently large hole bored in the side, make good nesting boxes. Jam, meat, and fish tins, as well as small boxes, may be utilised. Boxes may be made from odd bits of wood and tree bark. 


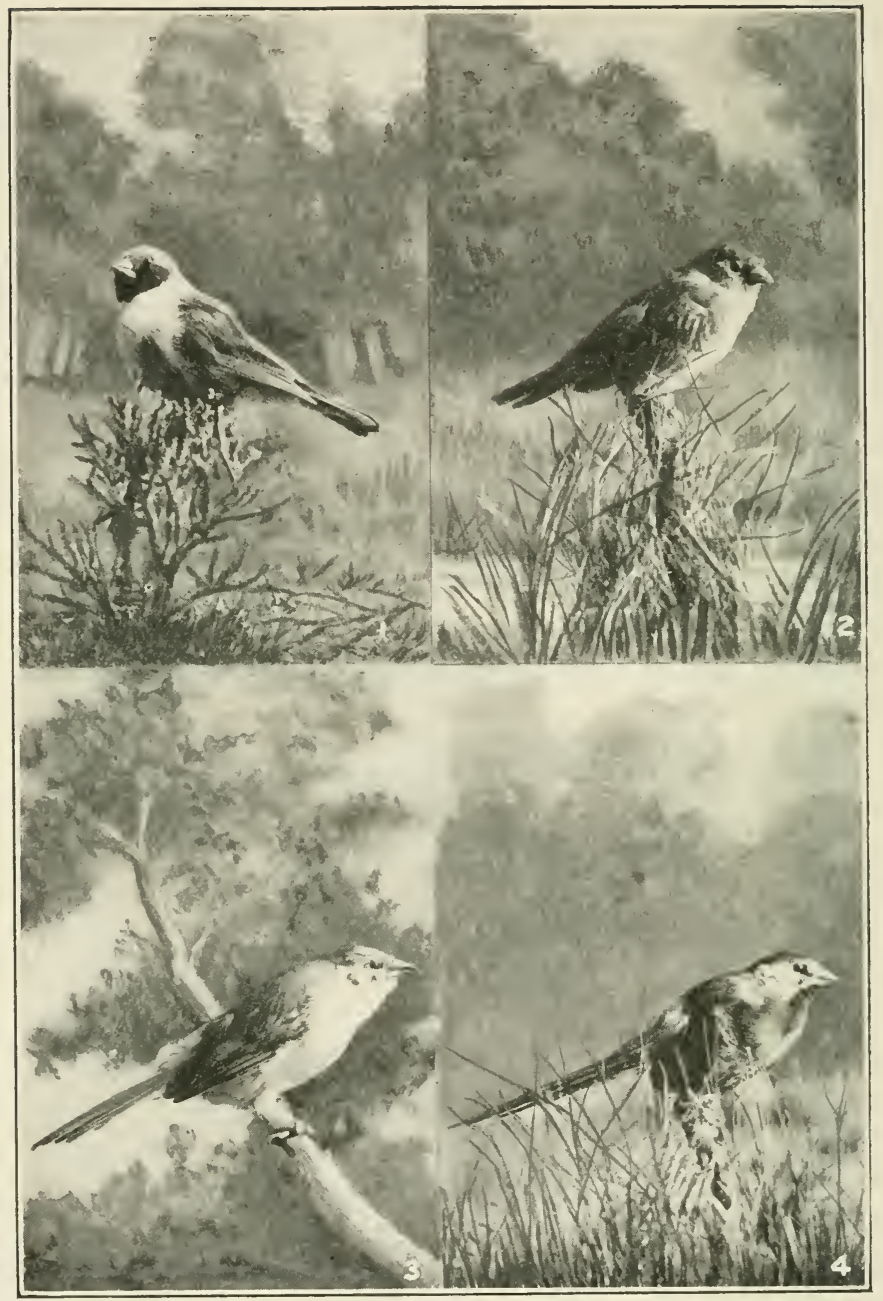

1. Dufresne's Waxbill, or See-see (Estrilda dufresnii), which inhabits the eastern side of South Africa. Male.

2. Orange-breasted Waxbill, or Zebra Waxbill (Estrilda subflava), which frequents the grass lands and margins of streams.

3. Blue-breasted Waxbill, or Cordon Bleu of bird fanciers (Estrilda angolensis).

4. Grenadine, or Violet-ear Waxbill (Estrilda grenatina). It inhabits the western side of South Africa. The male is exquisitely coloured.

These waxbills feed on the seeds of weeds and grasses, supplemented by insects, their larvæ, and eggs. 


\section{HOW TO ENCOURAGE BIRDS TO BREED}

Some forethought is necessary in choosing suitable places for the nesting boxes. A situation must be chosen which provides security against sun, wind, rain, and bird enemies. No exact dimensions are necessary for bird boxes. Anyone of average intelligence will know fairly well, from a study of the birds for which the boxes are intended, what size the nesting boxes ought to be. The most important requirements are the size of the entrance hole, the situation, and the environment. The hole must be sufficiently large to admit the birds comfortably.

The following directions by Edward Howe Forbush, of the State Department of Agriculture of Massachusetts, are clear and concise, and we cannot do better than reproduce them verbatim :-

" I. Let the roof be made tight, and overhang the entrance far enough to carry rain clear and keep the sun from shining in on the young.

"2. Do not make the bottom of the box too tight. If any rain drives in, it should run out.

" 3 . If the box tips forward a little on the side of the entrance hole when set in place, it will shed rain well. It should never lean backward.

" 4 . Provide a way of opening the box quickly, even if you intend to burn it, and replace it after the first season, as is done sometimes with gourds and shingle or bark boxes. It will be necessary from time to time to open the box for cleaning or for evicting gipsy moths and other pests or vermin.

" 5. Make the entrance hole and the box itself 
just large enough for the bird you want-no larger. This will tend to keep out larger birds as well as the birds' enemies, will give the bird a better chance to defend its home, and will save material.

" 6. Make nesting boxes of weathered wood, or paint or stain them with coloured linseed oil of a neutral tint resembling dead wood or bark, or put them up in the fall that they may become weather stained

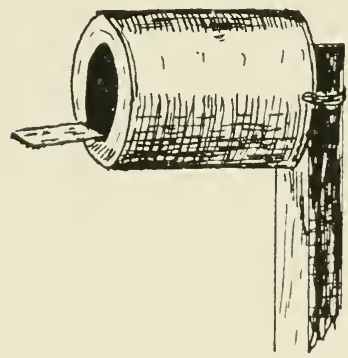

Old tins securely fixed to poles or branches make good nesting places for birds.

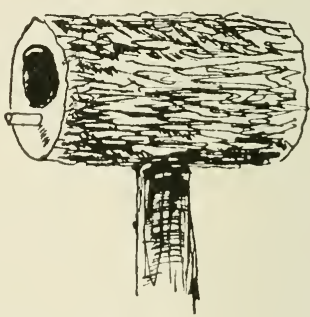

The bored out section of a tree trunk makes a nice nesting box.

before spring. Apparently birds are less suspicious of such boxes than of those made of new, bright lumber, but they have been known to use the newest of the new.

"7. Fix nesting boxes on buildings or on poles rather than on trees, and make them inaccessible to cats, squirrels, mice, rats, and snakes.

" 8. When it seems best to put them in trees, choose isolated trees which can be protected against cats, squirrels, weasels, etc.

"9. Ordinarily ventilation is unnecessary if the 206 


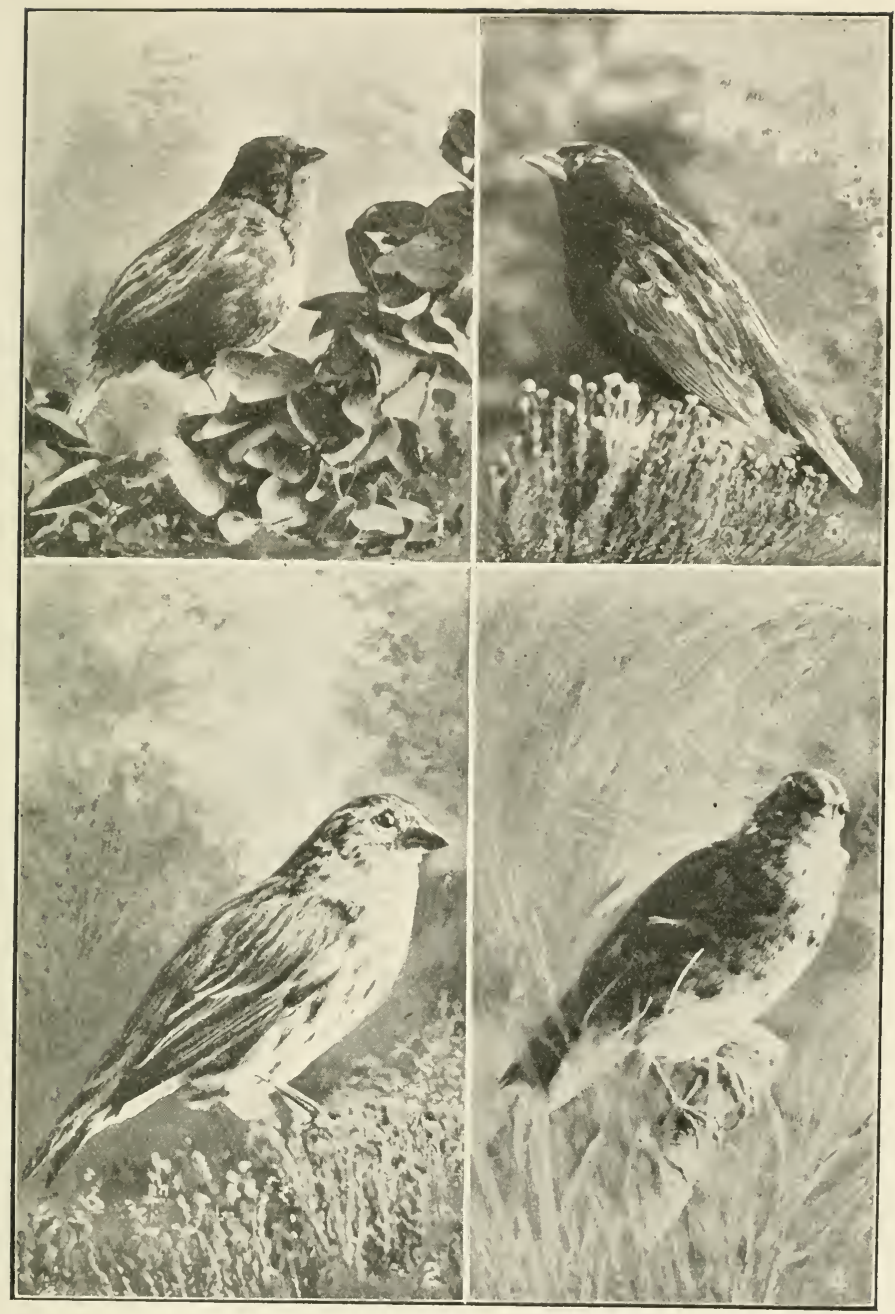

1. Taha Bishop Bird (Pyromelana taha) in summer plumage. Flitting amongst the reeds and rushes, this Bishop Bird is strikingly beautiful.

2. Black and Yellow Bishop Bird, or Yellow Kafir Fink (Pyromelana capensis), which haunts the reed beds, weed patches, and long grass. Winter plumage.

3. Black and Yellow Bishop Bird (Pyromelana capensis). In nuptial plumage.

4. Paradise Widow Bird (I'idua paradisea) in drab winter plumage. 
entrance is near the top of the box, as it should be; but in very hot summers young birds are believed to have died of heat in unshaded boxes mounted on poles. Ventilation may be provided by boring four $\frac{1}{2}$-inch holes in the sides of the box near the top and filling them with corks, which may be removed in extremely hot weather.

" IO. It is best to clean out the boxes each autumn, burning the old nesting material to destroy dirt and vermin, and putting in a little chaff, dry grass, or coarse sawdust as a foundation for a new nest."

A few practical details in regard to carrying out some of the above rules should be noted:

"If the roof of a nesting box, made of wood, is horizontal, the water will stand on it, and even if painted it will warp somewhat in drying unless heavily coated with good roof paint, or covered with zinc, some good roofing felt, or other waterproof material. It is well to have a cross piece nailed (with clinch nails) across the grain on the under side to prevent warping and splitting. If the top slopes downward at an angle of 45 degrees or less, and is well painted, the water will run off so fast that the roof will not warp much.

"Top, side, or front of the box may be hinged to open as a door, or fixed to fasten by means of nails, easily removed, slid loosely into sockets bored for them. White pine from $\frac{1}{2}$ to $\frac{7}{4}$ of an inch thick is the best lumber. Cedar and cypress are durable. Grocery or dry-goods' boxes may be used." 
It is unwise to nail boxes to timber trees, as the nails in time become overgrown by the wood and cause damage to saws and planing machinery. The boxes in these instances may be fastened to flat boards and screwed on to the trees. Another plan is to attach them to poles or fasten them with wires in the forks of branches. Nesting boxes should be covered with bark. Failing this, they may be stained or painted more or less the colour of the tree trunk or whatever base they may happen to be attached to.

To puzzle bird enemies, such as cats, squirrels, and snakes, nesting boxes may be suspended from branches with wire.

If the situation and environment of the nesting boxes are suitable, birds will soon take possession of them, provided the locality furnishes a sufficiency of insect food. Water is

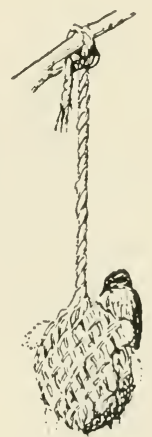

Crocheted Ball filled with raw cotton, feathers, etc., for lining nests. a necessity, and unless this is obtainable in the neighbourhood, drinking and bathing receptacles should be provided. On many South African farms the only water supply is from tanks, and it cannot be expected that birds will build in such an environment unless some provision is made for them by constructing shallow bathing and drinking troughs or basins. These can easily be made with concrete. Another aid in inducing birds to rear their young near a homestead is to provide nesting material, such VOL. I. 


\section{NATURAL HISTORY OF SOUTH AFRICA}

as hay, straw, cotton, hair, feathers, and string. The string should be cut into small pieces of 6 to 12 inches in length. These materials can be scattered about near the nesting boxes, or hung in bundles on fences or on branches of trees.

In countries where the common European sparrow occurs, it is often necessary to make war on them when they are too abundant, owing to their habit

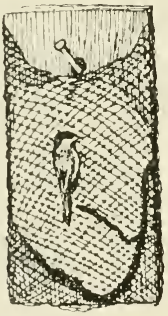

Crocheted Bag filled with suet, attached to board, then fixed to tree.

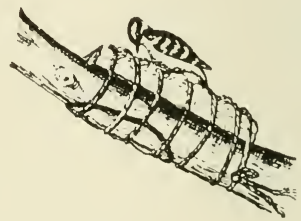

Suet tied to a branch.

of monopolising the nesting boxes. They often wait until a pair of useful birds have built a cosy nest in a box, and then boldly and impudently take possession of it. Eminently useful birds are driven from the neighbourhood in this way. The Cape sparrow or mossie does the same, only to a much lesser degree, owing probably to natural building sites being abundant.

During the cold winter months birds may be kept in the vicinity of a homestead by judicious feeding. Insects are comparatively scarce in winter, and unless 


\section{HOW TO ENCOURAGE BIRDS TO BREED}

this diet is supplemented, the great majority of the birds will be forced to migrate elsewhere. Birds which are fed during times of food scarcity almost always remain and breed in the neighbourhood, and unless persecuted they will spend their lives there.

A special feeding place should be chosen in a sunny situation sheltered from winds. The birds will soon find the spot and assemble from all over the neighbourhood to feed. As time goes on, greater numbers will be attracted, until there will be enough birds to exterminate the species of insects and allied forms of life which prey on the scanty winter vegetation. The birds during the winter months do not confine themselves to capturing active adult insects. They seek out and devour the eggs and chrysalides of insects-the eggs which otherwise would have hatched when the crops were young and succulent in the spring-time, and the chrysalides from which adult insects would have

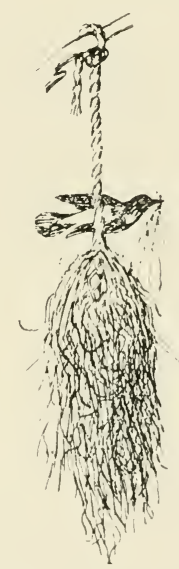

Basket filled with loose string, wood fibres or grass for nest building. emerged on the advent of warmer weather. Half of these insects would have been females capable of laying from a hundred to many thousands of eggs, according to the species. Apart, therefore, from the joy the presence of birds around our homesteads afford us, it is highly advantageous, from an economic point of view, to encourage birds to stay on farms in winter-time. 
A good feeding station may be made by erecting a platform on poles, or suspended from a tree, and roofed with reeds, rushes, or thatch. If a 6 -inch board is nailed around the four sides of the platform, the food will not be blown off by wind, and the roof will prevent it getting wet. Any sorts of small seeds, chaff, finely crushed mealies, coarse meal, broken

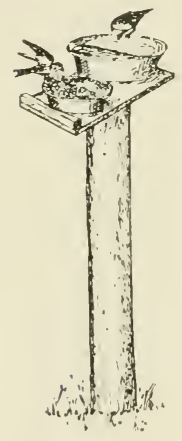

A Pan of mud and another of water for the use of swallows and martins in nest building. sunflower seeds, scraps of bread, vegetables, and in fact any soft edible substance, whether animal or vegetable, would provide good winter food for birds.

Instead of a platform, a clearing may be made on the ground for the food. The disadvantage of this, however, is-rats and mice have access to it.

When a natural water supply is not within reasonable distance, water must be provided. A dearth of water in summer often induces birds to attack soft, juicy fruits.

Swallows and martins are amongst the finest of insect killers. They take the mature insects on the wing, whereas the majority of other birds feed on the larvæ. In destroying adult female insects they eliminate the potential mothers of untold hosts of larvæ, hence every possible effort should be made to encourage them to breed on farms. To accomplish this desirable end, suitable nesting boxes should be affixed on the walls and roof of the homestead and outhouses, and 


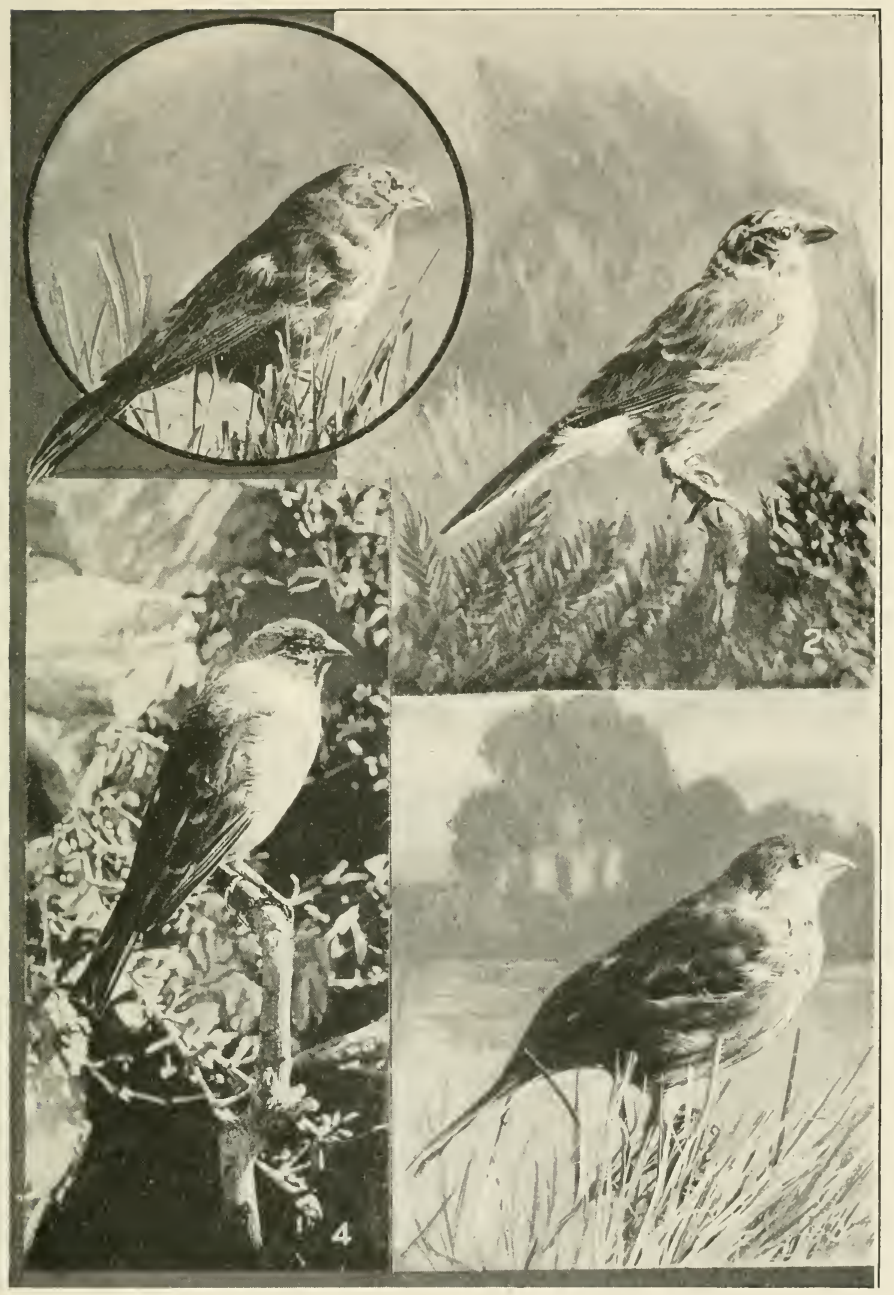

1. Sundevall's Seed-eater (Serinus scotops).

2. Streaky-headed Seed-eater (Poliospiza gularis).

3. Seed-eater (Serinus flaviventris). The seed-eaters feed on the seeds and berries of shrubs, and of grasses and weeds, supplemented by insects, their larva, and eggs.

4. Cape Canary (Serimus canicollis), the favourite cage bird of South Africa. 
also on poles out on the lands. The majority of the many species of swallows and martins build nests of mud, and unless there are muddy puddles in the near neighbourhood, these must be provided. A shallow dish of water and another of mud will fulfil all their requirements if they are replenished as often as needful. A shallow puddle of mud is the best. This can be kept from drying up by fixing a water barrel or other receptacle at the edge, and allowing the tap to drip.

\section{DESTRUCTIVE BIRDS}

Owing to the reduction of their natural enemies and an abundant supply of insects, certain species of granivorous and frugivorous birds breed and multiply so rapidly that they constitute a serious menace to the farmer. Those which are specially apt to increase unduly are the Cape sparrow, weaver, bishop, and widow birds. These are, with the exception of the sparrows, popularly termed "vinks." They often assemble in vast flocks and attack the ripening grain in the fields and do serious damage. I have seen large fields of wheat and millet completely destroyed by them. In these instances it is necessary to considerably reduce their numbers. Destroying their nestlings has been strongly advocated and is often practised. This is a wrong policy, because the birds at this period are at the zenith of their usefulness. When the fields 


\section{DESTRUC'TIVE BIRDS}

are not extensive, the birds can be kept off by Kafir boys beating tins, cracking whips, or springing a rattle, such as those used in former days by policemen, only somewhat larger.

When the wheat fields are extensive these measures usually fail, and it becomes necessary to destroy the birds by gun and poison. When the latter method is practised the greatest possible care should be taken to so place the poisoned grain that the troublesome birds only will have access to it, or at least so as to reduce the risk to a minimum of useful birds being poisoned. If the poisoned grain is spread out on platforms there is very little risk of beneficial ground birds eating it. Another method is to make large, shallow frames without a bottom, cover them with a wire mesh sufficiently coarse to allow the "vinks" to get through, then strew the poisoned grain on the ground and cover it with these crates. All uneaten grain should be buried or burned. The term "vink" is often specially applied to the widow and bishop birds.

The fruit crop is often preyed upon by colies or muis vogels (Colide), bulbuls (Crateropodide), redwinged starlings or rooivlerk, glossy starlings, and often by the little white eye (Zosterops).

Although the colies and bulbuls destroy numbers of insects, yet they are essentially fruit-eating birds, and undoubtedly play havoc in orchards, and are, in consequence, a serious pest to the fruit grower. When fruit is scarce they, especially the colies, will attack ripe, soft vegetables, such as pumpkins, marrows, and tomatoes. Poisoning, trapping, and shooting with 


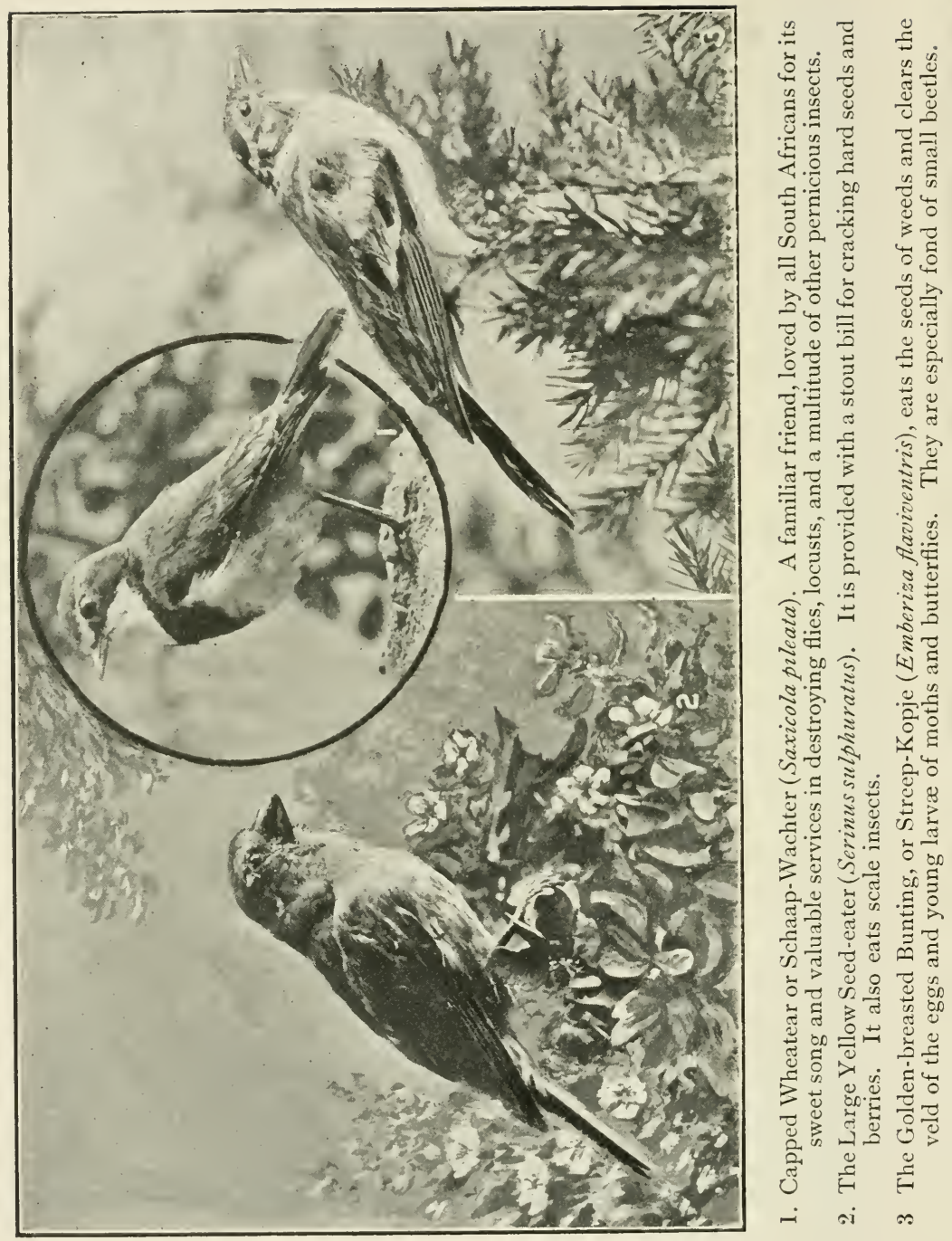


air-guns are the best means of destroying them. When a shot-gun is discharged in an orchard, useful insectivorous birds are terrified to such an extent that they flee in wild alarm and often do not return.

The red-winged and glossy starlings, although by Nature insectivorous birds, have become confirmed fruit-eaters, and they often do extensive damage to fruit in the orchards. Otherwise these starlings render excellent service in destroying insects.

The little white eye is one of our finest insecteaters, and it performs services of a special kind. It creeps through the bushes and trees, carefully scrutinising every leaf, twig, and shoot in search of the eggs and young larvæ of insects. It, however, does damage to soft, ripe fruits, but its depredations are usually not serious to the fruit grower. When, of course, a man has only a few fruit trees, a small flock of these birds will make serious inroads on his limited supply of fruit.

It is not the purpose of this book to detail all the ways and means of destroying birds which may do more harm than good to individual farmers. Should any particular bird become troublesome, and if its natural habits are not known, a letter of inquiry should be sent to the nearest public museum asking for the desired information. Then if the farmer, after weighing the evidence for and against, is convinced the bird is more destructive than beneficial to him, he should take the most efficient measures he is able to devise to reduce its numbers. If he is in doubt as to 


\section{NATURAL HISTORY OF SOUTH AFRICA}

what course to pursue in getting rid of the pest, he is advised to write to the Agricultural Department of the Government of the country he is resident in.

\section{TO POISON GRAIN-EATING BIRDS}

TAKE two heaped teaspoonfuls of finely powdered strychnine; take two to three, or even four, gallons of water in an old paraffin tin; add Io lbs. of sugar, brown or white, and boil until consistency of very thin cream. Take the syrup so made; sprinkle the powdered strychnine into it. The poison will not dissolve, so stir until you think the whole mixture is thoroughly permeated with strychnine. Now, pour the poisoned syrup on to small quantities of finely crushed mealies or wheat, and stir and mix well until the particles of grain are coated with a thin covering of the syrup. Leave it to dry, and it is ready.

Three gallons of syrup will mix two sugar bags full of crushed grain, and this will be enough to kill all the birds for one season. In putting down the bait, mix it with chaff or other grain.

Be careful: it is a deadly concoction. 


\section{NOTES ON NESTS, EGGS, AND YOUNG OF BIRDS}

There are two great divisions of birds, viz., those whose young are helpless at birth and for a longer or a shorter time afterwards, and those whose young are active from birth and can look after and feed themselves. The former are known as altricial, such for instance as starlings, weavers, hawks, herons, etc. The great majority of birds belong to this division. The other division is known as the præcocial, and chief among them are domestic fowls, partridges, plovers, and ducks. The altricial birds, with the exception of a few parasitical species, such as cuckoos, make a nest of one kind or another. Some nests are merely slight depressions on the ground, like those of the crowned lapwing and plovers, for instance; while others, such as those of the doves and pigeons, are merely loose bundles of twigs. Others, again, build the most elaborate nests.

The shape and situation of the nest is, in the majority of instances, determined by weather conditions, enemies, and food supply. The great majority of birds raise only one brood annually. A few species, such as the familiar Cape wagtail (Motacilla capensis), rear several broods during the course of the spring and summer seasons. In the world of birds, as with plant life, there is a systematic round or plan of life. At the best time of year for the purpose the birds build their nests, lay their eggs, and rear their young. 


\section{NATURAL HISTORY OF SOUTH AFRICA}

When this strenuous and all-important business is over, they moult and migrate to distant countries, retire to winter quarters, or go to other parts of the country where food is most plentiful at this season of the year. Some species live in the same environment throughout the year. Birds always select localities for nest building where food

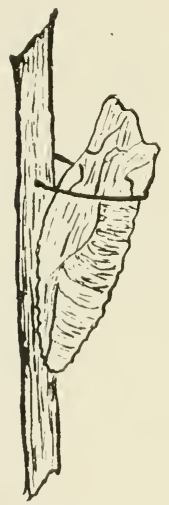

The Chrysalis of the

Butterfly strapped to a twig is a dainty morsel for a bird. is plentiful. The time chosen for rearing the young will always coincide with the time the favourite food is at its greatest abundance. During the spring and early summer the trees are putting on foliage, grass and other plant life is growing rapidly, and the crops are young and tender. Consequently it is at these times that tree and plant destroying insects are most abundant, and these enemies of plant life furnish the birds with ample nourishment for their children and themselves. Birds work so hard when rearing their young that they require twice and three times as much food as they do at other periods of the year.

It will be noticed that some species of birds build their nests in the very early spring; others a little later; while other sorts build at varying periods during the spring and summer. The time is determined by the character of the food and its abundance at these various times of the year. For instance, when caterpillars are plentiful, the birds which feed their young 


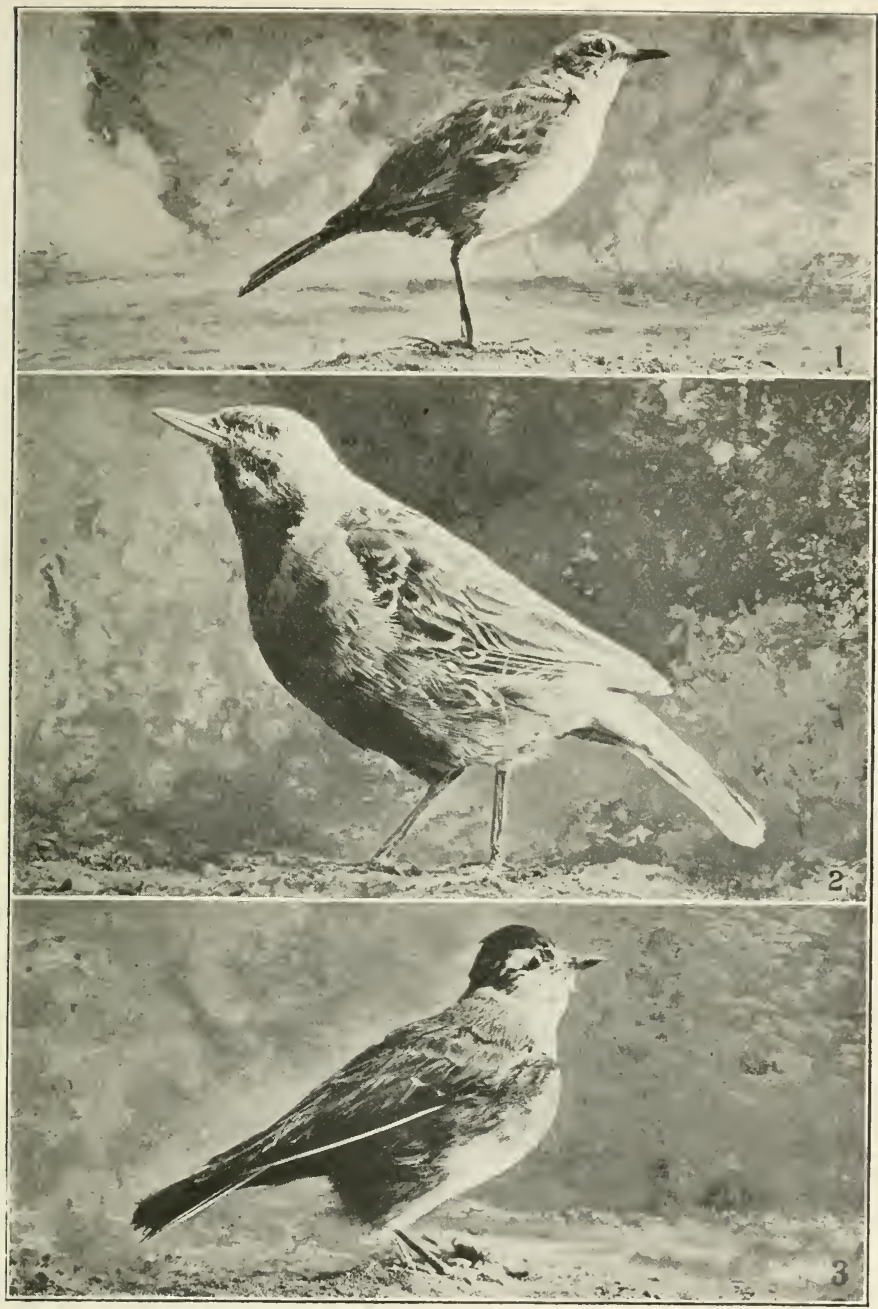

1. The Cinnamon-backed Pipit (Anthus pyrrhonotus) subsists on insects which it captures on the ground.

2. Orange-throated Lark, Long-claw, Cape Lark or Cut-throat Lark (Macronyx capensis). A large and handsome policeman of the veld.

3. Red-capped Lark (Tephrocorys cinerea), also known as the Inkelde Leeuwerk. Common on the veld all over South Africa. Feeds on insects. 
on this class of food breed at that time. I made a large number of observations in this connection, and found that the nestlings of the majority of the smaller birds were hatching from the eggs at the time the species of caterpillars which formed the bulk of their food were very young. These caterpillars provided the small and delicate young birds with the very food needed at this critical period of their lives. As they grew older and more robust, they required a greater quantity of food, and the caterpillars, which by this time had grown considerably, furnished exactly what was needful. A few species of birds rear their young in the winter. The sugar bird (Promerops) of South Africa is an example. The proteas and the aloes flower in the winter, and these birds feed their nestlings largely on the insects which infest the flowers of these plants.

\section{THE EGGS}

THE eggs of the majority of small birds hatch in from twelve to fourteen days. Those of the larger birds vary considerably, according to the species. The time for incubation usually ranges from fourteen days to a month. Many species of hawks take from twenty-one to twenty-eight days, and various of the duck tribe thirty days. Large birds, such as the ostrich and emu, take five to six weeks. When the 


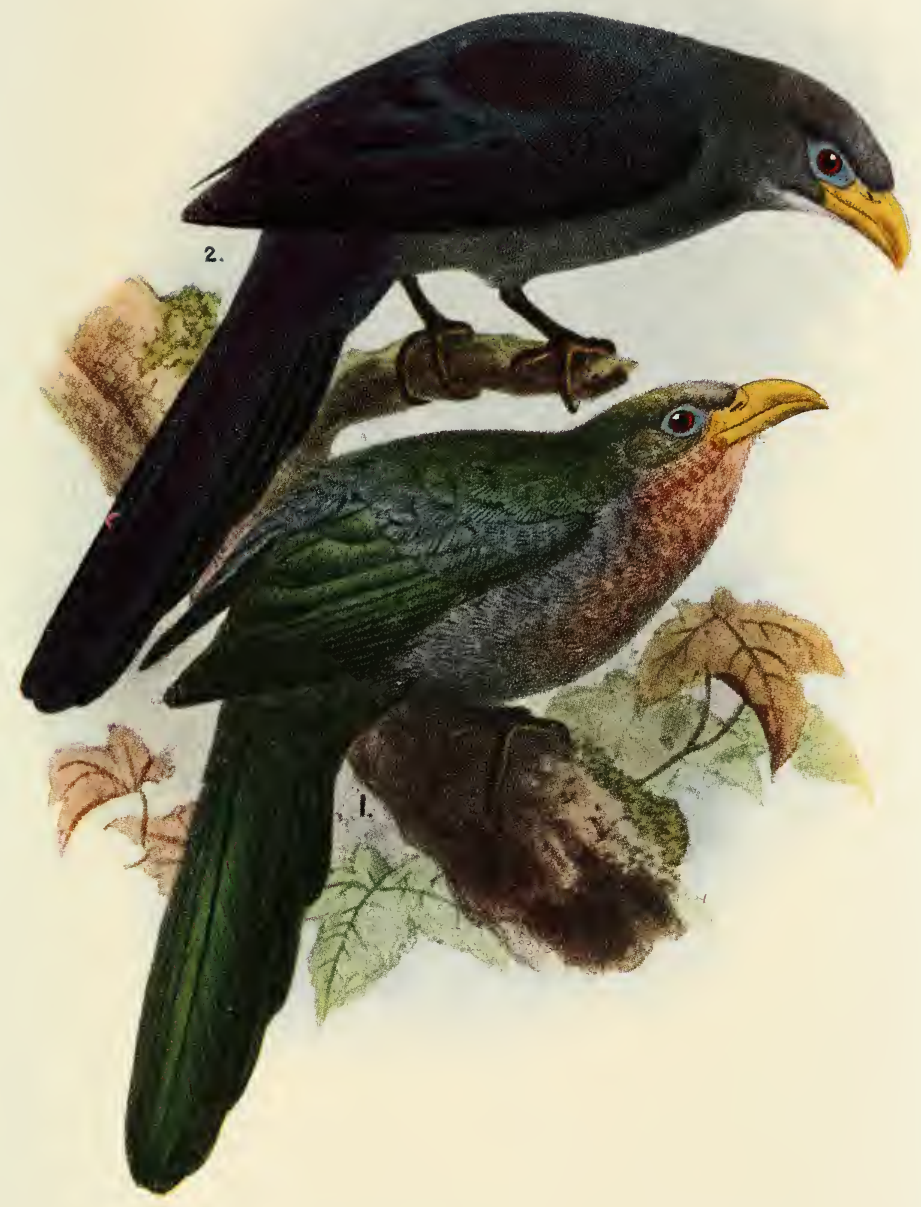

PLATE V - (1) Green Coucal (Ceuthmochares australis).

(2) West African Coucal (Ceuthmochares aereus)

The Coucal is a devourer of hairy caterpillars, beetles, grasshoppers and other insect vermin. 



\section{THE EGGS}

nest is robbed at the time the hen bird is laying, or before she begins to sit, in many instances she will lay a second clutch, and often several batches if the eggs are removed from the nest when laid. I have never yet observed any species of bird produce a second clutch of eggs after being robbed of her first clutch on which she had been sitting. When all the eggs are removed, very few species of birds will lay a second clutch in the same nest. A clutch of eggs is a full set, and they range from one to about twenty, according to the species of bird. The birds (præcocial) whose young are active and do not remain in the nest after birth, usually, but by no means always, produce far more eggs than those (altricial) whose young are helpless and remain in the nest for a longer or shorter period. The Cape gannet, which lays one egg, is an instance of the former; and certain species of francolins, which lay up to twenty eggs in a clutch, are examples of the latter. Moreover, the young of præcocial birds do not require nearly so much care on the part of the parents as do the birds of the altricial division. The size of the egg usually depends upon the size of the bird, but not always. The eggs of the Cape thrush (Turdus olivaceus), for instance, are larger than the majority of the eggs of birds of similar size, but these are exceptions to the general rule. The colour of the egg is caused by pigment which is deposited on it when the shell is forming within the bird. In some birds the colours are in the shell substance and on the surface. This is due to the deposition of the colour during the whole time the shell 
is being formed. Sometimes the variation in colour is due to an access of carbonate of lime being deposited on the shell, as instanced in many sea birds' eggs.

The colouring and markings on birds' eggs are certainly, in the great majority of instances, for the purpose of rendering them less conspicuous to enemies. The reptilian ancestors of birds laid white eggs, as they do to-day, and buried or otherwise hid them. Many species of birds which lay white eggs cover them up when they leave the nest. The doves and pigeons have white eggs which are very conspicuous lying in their flimsy bed of twigs, but both sexes of these birds assist in the incubation process, and consequently the eggs are seldom exposed.

The colour and markings, for instance, of plovers' and lapwings' eggs render them so inconspicuous that it is extremely difficult to see them even when close at hand and within full view. The eggs of birds which nest in holes are usually white. There are many exceptions, however. Some of the South African species of starlings which nest at the ends of deep holes in banks produce blue eggs. Again, many of the weavers, bishop, and widow birds build domed nests, and the eggs are not visible to enemies, yet the majority of them have coloured and spotted eggs. The causes of the coloration of birds' eggs need a great deal more study before we can dogmatise on the subject.

Eggs vary a good deal in shape. Those of many birds which deposit their eggs on rocks and ledges of cliffs are shaped in such a way that they 


\section{THE YOUNG BIRD}

do not roll off. When blown by the wind they may move, but they remain on the same spot. Such eggs are pyriform. The conical eggs of plovers, snipe, etc., lie in the nest with the small end inwards. Packed thus they take up the minimum amount of space, and can be fully covered by the parent bird. Other kinds of eggs are elliptical and spherical.

When the chick hatches, the parent bird carries the broken shell some distance and drops it. A few species of birds simply cast it out of the nest.

\section{THE YOUNG BIRD}

THE young of præcocial birds, of which the game birds are examples, although active from birth, are unable to fly. They are covered with a thick, warm coat of down, and one or both parents lead them about in search of food. When alarmed they instantly scatter and, crouching on the ground, as immovable as a pebble they wait until the danger is past. The mother bird employs many ingenious ruses to lead the enemy away from the vicinity of her brood. She pretends to be crippled and flutters away, or runs to a distance with head low, and then, exposing her body, she flutters her wings and cries shrilly to endeavour to deceive the enemy into the belief the young are with her, or to lead it to think she is unable to fly. When a bird of prey appears overhead, the mother

VOL. I.

225

I 5 
usually utters a low cry of warning, and she and the brood instantly flatten themselves down and remain perfectly still. The bird of prey, although exceedingly keen sighted, is always on the lookout for a moving object; and the instant it detects a rodent, a bird, or any other likely form of prey, it drops on it like a stone. Young ground-frequenting birds know instinctively that their best chance of escaping observation is to remain perfectly still. The young of ducks and other aquatic birds take to the water and swim and dive without any training by the parent. When alarmed the mother duck instantly leads her brood into the midst of reeds, rushes, and other cover. If on a lagoon or lake, she often takes them as far from land as possible. I suddenly surprised a wild duck in a quiet river pool. The moment she observed me she emitted a warning "quack" and dived, followed by her brood. The mother and young seemed to disappear at one and the same moment. They evidently swam under the water and came to the surface in the midst of the rushes near the bank, for I saw no more of them. On another occasion I encountered a red-knobbed coot (Fulica cristata) on a river pool. The disappearance of herself and brood under water was practically instantaneous. There was a momentary glimpse, and nothing more.

The young of this division of birds feed very largely on insect life which infests the ground and play havoc with vegetation. The economic value of the young so-called game birds is simply incalculable. 


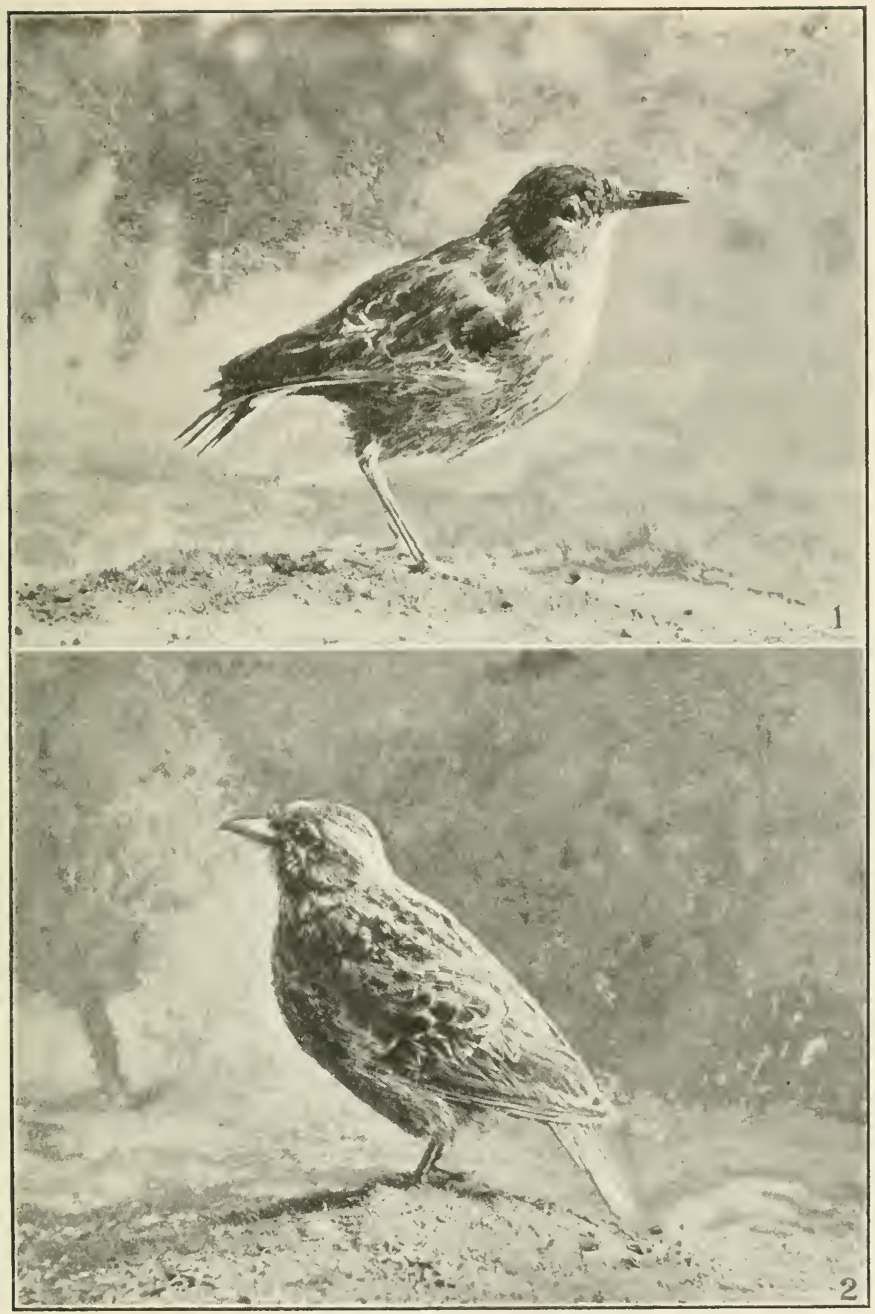

1. Rufous Long-billed Lark (Certhilauda rufula) which seeks its insect prey on the ground in open and stony localities.

2. Bar-tailed Lark, or Clapart Leeuwerk (Mirafra apiata).

The various species of larks are Nature's policemen of the veld, giving their services gratis, for they do not levy any toll on the products of man. In return for these services, the children of men are allowed to shoot them for amusement, and rob their nests. 
Yet, curious and strange to say, this class of bird is only afforded a certain measure of protection for the one and only purpose of freeing it from persecution sufficiently long to enable it to incubate its eggs and rear its young until they are large enough to be shot for sport. I have gone carefully into the matter, and find that the services of the majority of game birds are each worth at least $£ 20$ a year to man as insect destroyers. Yet they are shot in thousands annually and their bodies eaten; or sold on the market for a few pence or shillings.

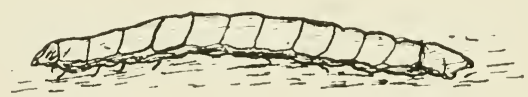

The feathered enemies of the wire-worm are killed for sport.

There is another factor in this partial protection of game birds. They are so terrorised by the sportsman with his gun and dogs during the open season, that they flee in wild alarm to haunts as remote from man as they can find. The result is, large numbers live and breed there, and the stock farmer loses their services on his lands.

The young of altricial birds are helpless at birth, and remain in the nest for a longer or shorter period, according to the species. During this time, which, in the majority of small birds, averages two weeks, and in larger birds three weeks and longer, the parent birds feed the helpless young. For a month after leaving the nest the young birds have still to be 


\section{THE YOUNG BIRD}

tended and fed by the parents while their muscles and bones are strengthening and their feathers developing. Meanwhile they practise the art of flying, and their parents teach them how to seek their food.

The nestling birds are fed in various ways. Some species of birds swallow the food and regurgitate it from the crop or stomach into the throat of the young bird. Other species, viz., many of the sea birds, the doves, and the humming birds, employ this method until the young are able to feed themselves. Others, again, do so only when the nestlings are very young and delicate. Some of the passerine birds feed their young for a few days in this way, but they, with the great majority of the others, thrust the food in its natural state into the gaping mouths of their youngsters. The diet is carefully chosen. The softest and tenderest insect larvæ are given to the very young nestlings. The young of the smaller species of birds are fed every few minutes during the greater portion of the daylight hours. The food, as already mentioned, is at first small and tender to suit the delicate stomachs of the offspring. From day to day larger prey is brought, and when too large the parents dismember it with their bills.

The larger birds usually feed their nestlings at much longer intervals, and often many hours pass between each visit to the nest, but the young receive a large bulk of food at a meal. The birds of prey bring the food to the nest and proceed to tear it to pieces. When a bit is torn off it is thrust into the gaping mouth of the eager, squealing youngster. 
The young of the smaller birds, especially the perching birds, eat great quantities of food, and their rate of growth is correspondingly rapid. Visiting a nest one day I found the young ones to be tiny, blind, bare, and helpless little mites. Fourteen days later I peeped into the nest, and away flew the brood in all directions into the bushes. Applying the same rate of growth to a human baby we would find that if it were $7 \mathrm{lbs}$. in weight when born, it would be about I 40 lbs. when twelve days old.

$\mathrm{W}$ ise Nature has provided against young birds being overfed. The throat of the nestling is very sensitive, and when the stomach is ready to receive more food, the throat nerves will instantly respond with a simultaneous contraction of the gullet. If there is no response, the parent bird withdraws the morsel and thrusts it into the gaping mouth of another nestling. In the human baby the gastric or stomach nerves are so delicately adjusted that when too much food is swallowed, or if the stomach is not in a fit condition to digest it, a reflex motion is set up, and the contents are cast out. Through constant overfeeding, the human stomach soon loses its natural sensitiveness and the surplus food, if digested, forms fat. If undigested it generates various poisons, and slowly but surely undermines the constitution and brings about a variety of ills which cause premature death. 


\section{DEVOTION AND LANGUAGE,}

\section{SANITATION}

Some of the nestling birds in open nests, notably the birds of prey, void their excrement over the edge of the nest. With but few exceptions, the birds which are included in the great order Passeres void their excreta in the nest. It is, however, enclosed in a membraneous sac, and is subsequently removed by the parents. In these ways Nature guards against the nests becoming insanitary. There are a few species of birds, however, which utterly neglect nest sanitation. The South African hoopoe is one, and the hornbill is another.

\section{DEVOTION AND LANGUAGE}

THE devotion of parent birds to their young is so great that they will often take the most appalling risks in their defence. I have, on more than one occasion, seen parent birds of small species attack and furiously peck the head of a boomslang (tree snake) when it was in the act of devouring their nestlings. Many and various are the ruses, stratagems, and methods adopted by birds in defence of their young.

It pleases us to think we are the only species of living creature on earth capable of speech. Animals, too, have a language of their own. True, it is limited, but nevertheless it is a form of speech. A low cry of 


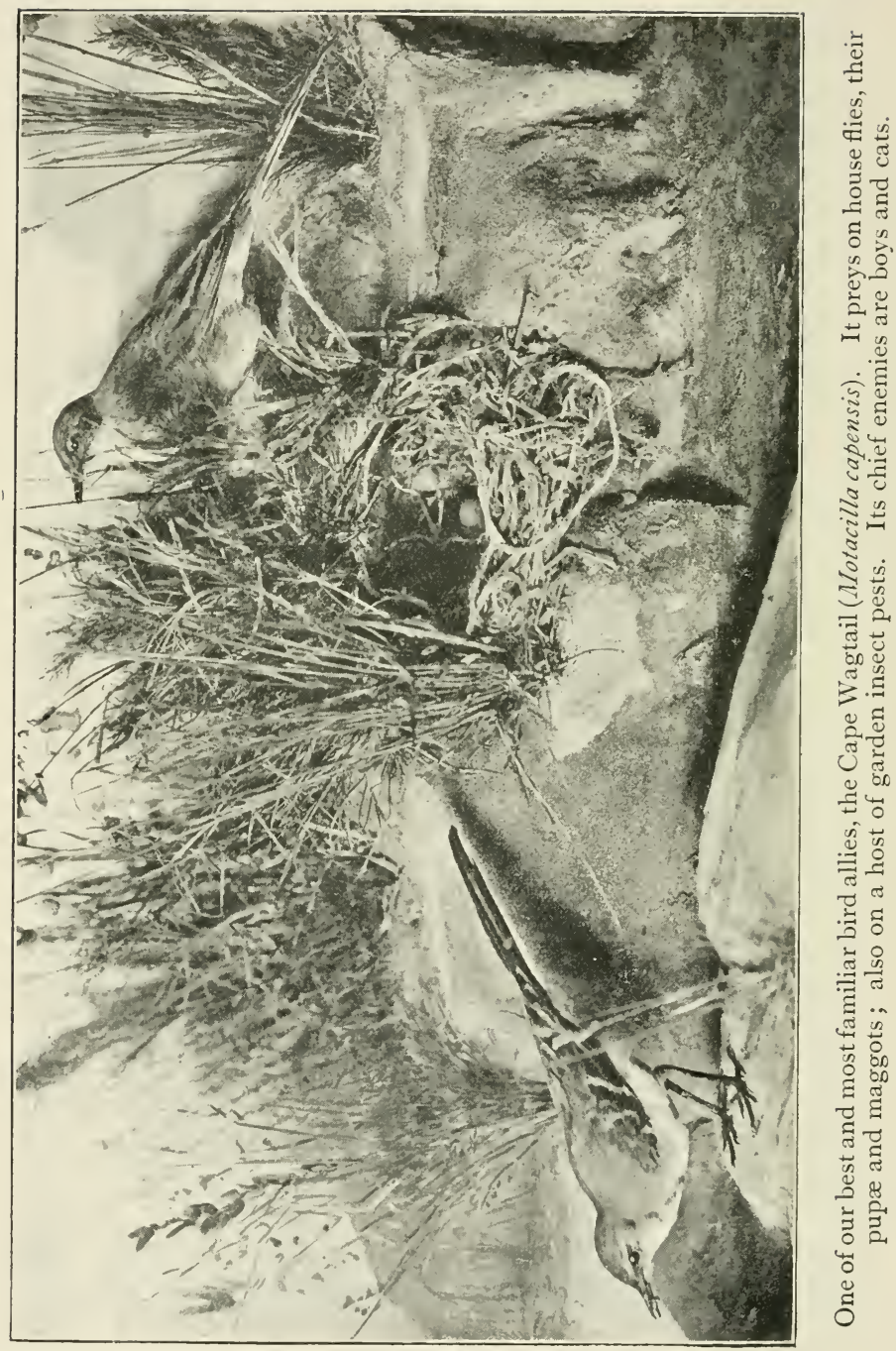


alarm by a partridge will send its brood instantly to cover ; and they will remain as still as stones until she tells them the coast is clear. When a hen catches a worm she emits certain sounds, which, in our language, could be interpreted "come quick, I have food for you." Instantly the chicks eagerly flock round her. Bird language is a most interesting study. Space forbids enlarging upon it here.

\section{FLIGHT}

THE young of the great majority of birds, on leaving the nest, can only make short, clumsy flights ; and it is at this time large numbers fall a ready prey to enemies. The young swallow, on the contrary, on first leaving the nest has full mastery of the air. The nest is used as a roosting place, as a rule, until the young birds are quite capable of taking care of themselves. The young of the wandering albatross remains in the nest for a year, and only vacates it when the parent birds require the nest again. It has, even then, to be actually forced to vacate its baby home to go forth into the wide world alone.

\section{PLUMAGE}

THE young of altricial birds are naked at birth except for slight traces of filmy down on the back. The feathers soon begin to grow, and when the young 
bird leaves the nest its wings are usually sufficiently developed to enable it to make short, uncertain flights. All birds moult in the autumn. Moulting does not take place until the breeding season is over. The wing feathers of altricial birds are shed so gradually that flight is not seriously interfered with. With swimming birds, however, the reverse is the case. They shed all their wing feathers at the same time and become flightless. When the moulting season approaches they resort to secluded lagoons, lakes, rivers, bays, etc., where they can live in comparative security on the water while their new wing feathers are growing.

When feathers are plucked out by accident, others grow. When the wing or tail feathers are cut, the bird does not get another set until the old ones are shed at the usual moulting season. The male bird is, as a general rule, more handsome than the female. The painted snipe (Rostratula capensis) is one of the exceptions. With some species of birds the plumage is similar in both sexes. Climate affects the colour of birds' plumage more or less profoundly. Many species of birds are extensively distributed. A species which inhabits the more or less arid portions of the country will be noticed to be paler in colour than examples of the same species inhabiting humid districts. Several degrees of variation may often be observed in birds of the same species. This has given rise to subspecies. Sometimes the variation is slight, and at other times it is very pronounced. The climate and food supply affect the size of the bird, as well as 


\section{PLUMAGE}

its feathers. Birds of the same species are often found to differ in size in various parts of the country. Climatic changes and food supply affect the bird so greatly that it is sometimes a difficult matter to determine whether it is a subspecies or a new species.

In course of time many subspecies become so profoundly modified in appearance that they differ from the type sufficiently to be designated a new species. This gradual change may go on for many thousands of years before very marked variations take place in the plumage and body of the bird.

To secure a mate the male bird is obliged to court the female. This courtship is more or less prolonged, according to the species and the fastidiousness or otherwise of the lady. Consequently the males have the handsomer plumage, and they display it to the greatest possible advantage before their lady love, who eventually selects the most virile and good-looking aspirant. This is a provision of Nature to prevent deterioration of the race. The female painted snipe is more brightly coloured and larger than the male, and we naturally seek for an explanation of this exception to the general rule of the male bird being the handsomer. The probable explanation lies in the fact that there are usually more females than males of this species.

I collected these birds at various seasons of the year in Natal, and the females always predominated. 


\section{THE FOOD SUPPLY}

ManY species of birds are compelled to migrate to secure a sufficiency of food. If swallows, for instance, were not migratory, only a comparative few would find sufficient food to carry them through the winter, even in temperate climates; while in those countries like the British Isles where the winters are severe, the swallows would probably

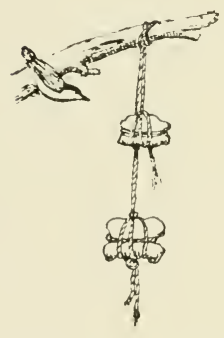

Suet hung by string from branch. Suet is an excellent winter food.

become extinct. By migrating from the northern hemisphere of the earth to the south in the autumn, migratory birds are perpetually in spring and summer conditions; and at these times insect food is at its maximum of abundance. This is a wise provision of Nature. Even with the present large number of migratory birds, the insect hosts are able to more or less hold their own. When a severe blizzard or other sudden weather changes occur, great numbers of birds perish, and there is a corresponding increase in the insect world, and insect plagues are prevalent. Sometimes a catastrophe overtakes the migrating hosts of birds. They are occasionally caught in a wind storm of great violence and driven out to sea to perish miserably; or they may be struck down by hail and heavy rain. Should this occur, insect pests increase alarmingly. Insectivorous birds cannot be too abundant. If there 


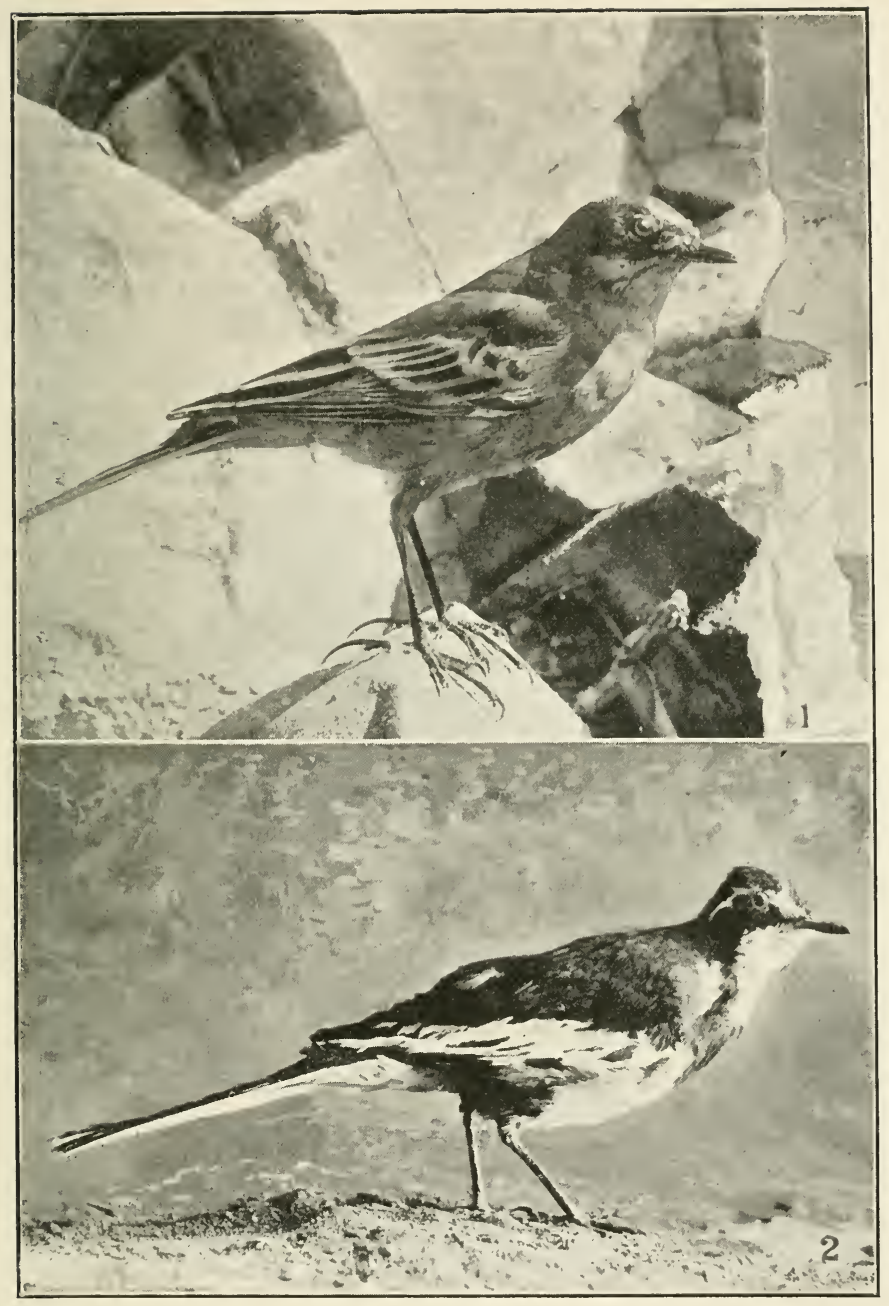

1. Ray's Yellow Wagtail (Motacilla campestris) is a rare visitor to South Africa. It migrates from Europe and wanders as far south as Port Elizabeth.

2. African Pied Wagtail (Motacilla vidua) feeds largely on mosquitoes and flies which it catches on the wing; also young water snails and allied forms of life. 
is not a sufficient food supply numbers die off, and the balance of Nature is restored. This is not so with many of the seed-eating kinds. When the seeds of grass and other wild plants and insects fail them, they attack the farmers' grain crops, and their numbers have to be reduced by human agency. Birds rarely store food. They seek and consume what food is needful for the day, and their movements are consequently guided and determined by their food supply. When insects are superabundant in any locality, the birds soon become aware of the fact, and flock in from the surrounding districts and prey upon the pests, leaving only a few survivors lurking in hiding places.

Birds have a high bodily temperature, and to keep it up a large amount of food is needful. When deprived of food, a bird rapidly dies. Mammals, with but few exceptions, can fast for a month and more. It is a common practice for people to abstain from all food for two weeks to a month for various health reasons. Food is, therefore, an ever-present necessity for the bird.

The jack hanger or fiskal shrike (Lanius collaris) is one of the few exceptions amongst birds which store food. When insects are abundant it catches and impales them on thorns and barbed wire fences for its future needs. I have frequently seen a large assortment of beetles, locusts, and mice stored away by a pair of fiskal shrikes, and have kept them in aviaries to study their habits. 


\section{NATURAL ENEMIES OF BIRDS}

L.IKE all other living creatures, birds have their natural enemies. The natural enemies of bird life sufficed, in the past, to maintain the balance between bird and insect. However, that era is dead and gone. Man has made his advent and has overspread the earth. As the ages roll by his struggle for existence will become increasingly keen, until every foot of arable soil will be cultivated. The utilisation of the soil by man for the production of food and timber has resulted in an abnormal increase of insect life. Food of a rich and succulent nature is provided by man for the insect hosts, and he at the same time has consistently and persistently persecuted the feathered enemies of insects. The production of crops favours the rapid multiplication of insect life. Consequently it is necessary for us to take active measures to conserve bird life. We must avail ourselves of every means of increasing the numbers of insect-eating birds.

The destruction of some of the principal natural enemies of birds is one of those ways. We no longer require the services of these natural enemies of bird life.

$\mathrm{W}$ ith the advent of the agricultural and pastoral phases of human culture, conditions have changed. We are apt to regard all snakes, for instance, as enemies. This is a grave error. The great majority of snakes prey eagerly on rats. A number of species of snakes in South Africa are non-venomous ; many others, although more or less venomous, rarely inflict a poisonous 
bite on man or beast for the good reasons that (I) they are exceedingly timid and seldom attempt to bite; and (2) their venom fangs are set so far back in the jaw that when they do bite with malicious intent, they rarely succeed in driving their fangs home. This great host of snakes preys on rats and mice. These rodents are amongst man's worst enemies. They prey incessantly upon the products of his hands and his brain. They rob him of a large percentage of his food. They not only do this. They devour the eggs and nestlings of birds, and attack and destroy adult birds during the hours of darkness. In these ways they largely contribute to the increase of noxious insect life. There are, however, a few snakes in South Africa which are inveterate enemies of bird life. They are the mamba (Dendraspis angusticeps), eggeater (Dasypeltis scabra), boomslang (Dispholidus typus), and bird snake (Theltornis kirtlandii). The egg-eater preys chiefly on the eggs and nestlings of birds. The boomslang and bird snake feed not only on the eggs and young, but on adult birds. In addition, a favourite food of theirs is that most useful of all lizards-the chameleon. This lizard feeds exclusively on insects which it finds amidst the foliage of trees and shrubs.

If these snakes confined themselves only to those species of birds such as the weaver, bishop, and widow birds, not much, if any, harm would be done; but they feed indiscriminately on all the smaller species of birds.

The Nilotic monitor lizard (I aranus niloticus) robs 


\section{NATURAL, ENEMIES OF BIRDS}

the nests of birds which build in the neighbourhood of its watery haunts. This lizard is able to climb trees with ease, and the destruction it causes in the ranks of useful birds is not balanced by the harmful insects it disposes of. In fact this monitor lizard may be safely regarded as a reptile of little economic value in South Africa. In Central Africa it performs a useful service in reducing the crocodiles by feeding on their eggs and young. It feeds largely on freshwater crabs, which are useful scavengers; and also on frogs (Rana) and toads (Bufo). Frogs and toads are insect feeders, and therefore of considerable economic value.

The various wild cats, genets, and muishonds prey on birds to a more or less considerable extent, but their depredations are mostly confined to ground birds. As an offset against the harm they do to bird life, they prey largely on rats and mice. The mungoose and muishond render the highest services to man in this way. I have ascertained, after many years of close observation, that the chief diet of these little carnivorous animals consists of rats and mice.

Squirrels destroy the eggs and young of birds to a considerable extent in localities where these animals are numerous. The Carolina squirrel (Sciurus carolinensis) was introduced into Cape Town many years ago, and has multiplied so alarmingly that it is now a serious menace to the fruit grower and to our native birds.

The vervet monkeys, which dwell in the wooded districts of South Africa, are unqualified enemies of

VOL. I. 


\section{NATURAL HISTORY OF SOUTH AFRICA}

bird life. They eagerly seek out the nests of birds which build in trees and devour their eggs and nestlings.

The domestic cat has been, and is, very much overrated as a destroyer of rats and mice. The harm it does to bird life in and about towns and villages and around homesteads is immense. Well-fed cats usually do not trouble to hunt down wild birds to any considerable degree, but the numbers of uncared for and semiwild domestic cats in and about cities, villages, farms, and in the woods is much larger than is generally believed. Cats at all times prefer birds to rats for food. Cats which I have possessed at various times developed into bird hunters, and after a time they refused to eat rats and mice which were caught in traps and given them.

The grounds of the Port Elizabeth Museum were frequented by two or three dozen pairs of laughing turtle doves, and a variety of other birds were to be seen amidst the shrubs and flower beds at all times of the day.

A vagabond cat appeared, and within three months the birds had all been captured and eaten by it. This cat refused poisoned bait of various tempting kinds, and it was some considerable time before we were able to encompass its death. It used to lie concealed, and spring out upon the unsuspecting bird and strike it down as it rose to fly.

Cats breed rapidly, and a few ownerless cats will soon populate a locality and practically exterminate the birds. Cats are tough and hardy, and their enemies 


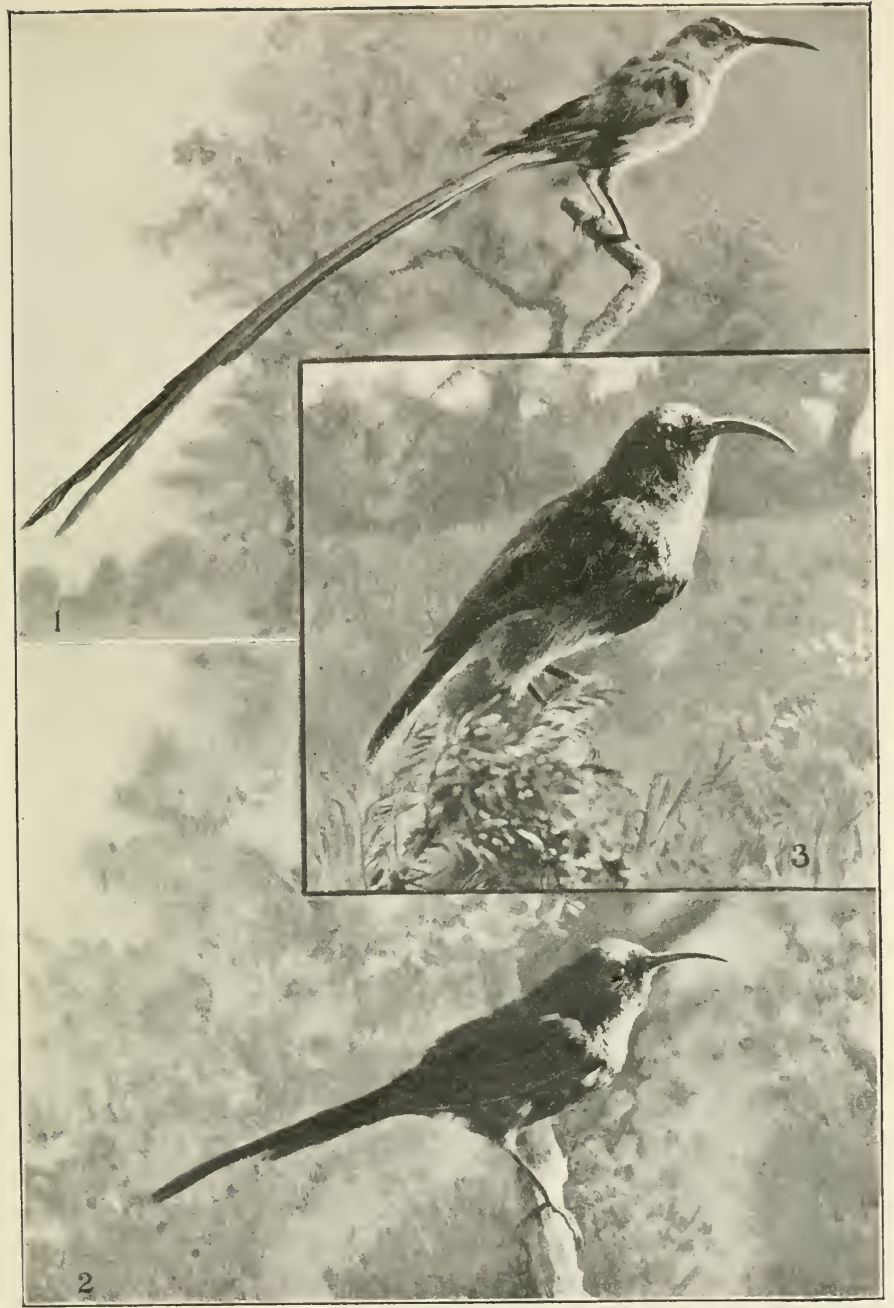

1. Cape Long-tailed Sugar Bird (Promerops cafer). Unlike most other birds, it breeds in winter when the proteas and aloes are in bloom. It lives on nectar and insects, and renders valuable service in the cross-fertilisation of plants.

2. The Orange-breasted Sun Bird (Anthobaphes violacea) is confined to the Cape Province. Its favourite haunts are patches of heath and proteas.

3. Greater Double-collared Sun Bird (Cinnyris afer) glitters with metallic green and steel blue, and its breast is barred with bright yellow. 


\section{NATURAL HISTORY OF SOUTH AFRICA}

are few, consequently, unless kept severely in check by man, they multiply alarmingly.

The greatest possible efforts should be made to preserve bird life in cities, villages, and around our homesteads in the suburbs and country, for two good reasons: (I) We need the co-operation of every insectivorous bird in keeping in check the insects which ravage our gardens. (2) The æsthetic value of birds in our neighbourhood is highly important in the evolution of our higher brain centres.

"It's a good thing to scatter sunshine,

It's the best way we know ;

It's a good thing to make hearts happy,

To bring gladness where we go."

\section{WHAT THE DESTRUCTION OF BIRDS MEANS TO YOU}

I. InSECT-Borne diseases attack you, your wife, and children. Results-financial losses, worry, anxiety, damaged constitutions. Often death of beloved wife or children.

2. Insect-borne diseases play havoc with your stock and cause financial ruin, or a heavy annual drain upon your resources.

3. Insects devour your pasturage, your standing crops, your root crops, your timber trees, your fruit and fruit trees, your dwellings, your carefully stored-up 


\section{WHAT DESTRUCTION OF BIRDS MEANS}

foodstuffs, your furniture ; and, in fact, everything you grow and the other goods you possess.

4. Insects prevent the colonisation of thousands of square miles of land.

5. Insects make man's struggle for existence 80 per cent. heavier than it otherwise would be.

6 . Insects, by bringing red ruin, vexations, and troubles to farmers, cause every individual in the country to suffer more or less indirectly.

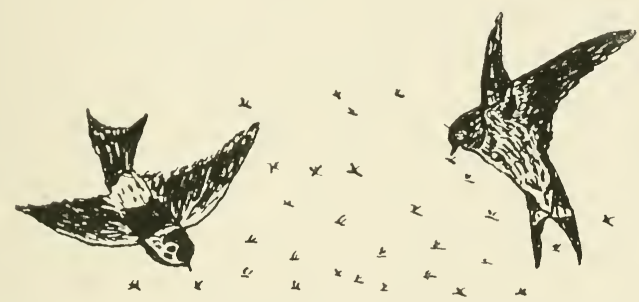

The Swallows and Martins hawk the insects in the air.

7. Rats and mice, which owls and hawks prey on: carry diseases to man and stock animals. They devour everything eatable he produces. They gnaw and destroy the work of his brain and hands.

8. Overcome the insect hosts and armies of rats and mice, and you will have-

(i.) The reduction by two-thirds of diseases which afflict man and beast.

(ii.) Health, wealth, happiness, and long life.

(iii.) Your country will be able to support many times its present population.

(iv.) You will be able to thickly populate thousands 245 
of square miles of fertile territory which at present are in the grip of insects.

\section{HOW TO FIGHT AND CONQUER THE ENEMY}

I. Put birds under the protection of the law, and at the same time create the necessary machinery for the stern, unrelenting enforcement of those laws.

2. Suppress the catapult, and impose a heavy tax on owners of air-guns and shot-guns.

3. Teach school children economic natural history, and especially the value of birds to man.

4. Prohibit the exportation or importation of the plumage of wild birds.

5. Station good energetic men with a thorough training in economic entomology and the relation of birds to insects all over the country to fight the insect hosts and to give advice to the farmers. Money spent in this way is money wisely spent. In South Africa a hundred such men are required. The resulting increased prosperity of farmers would add largely to the Government revenue.

"To welcome new procedures is the test of greatness, for it betokens breadth of view. Most men's knowledge is cut on a bias of early acquisition, and cannot be adapted to new habits of thought."-LOWELL. 


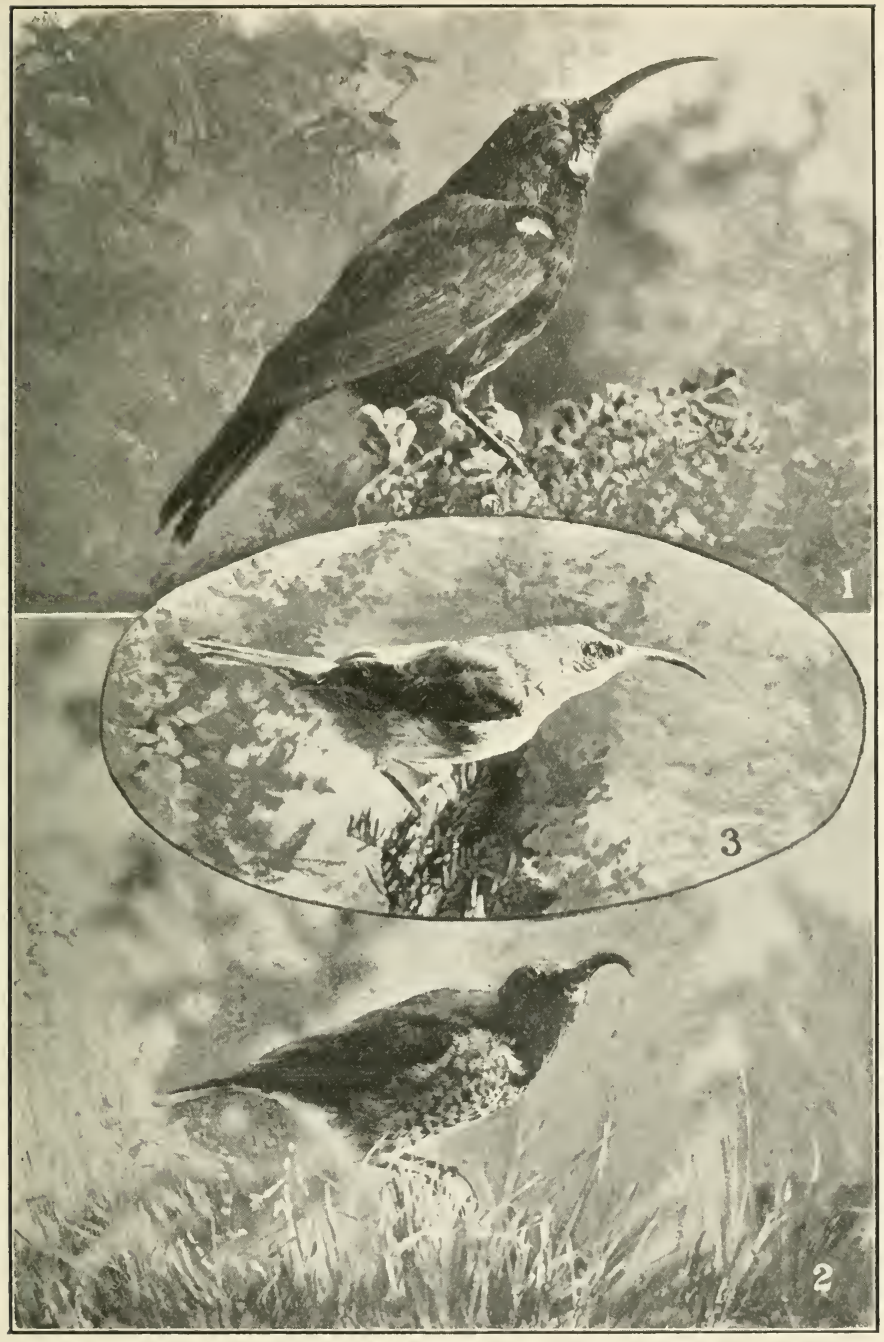

1. The Black Sun Bird (Cinnyris amethystinus) is dressed in velvety black, with a glittering and shimmering amethyst patch on the forehead and throat. (Male.)

2. Black Sun Bird. (Immature male.)

3. Mouse-coloured Sun Bird (Cinnyris verreauxi). The Sun Birds, or Honeysuckers of every species, render great service to man. They feed on insects, and are active agents in the cross-fertilisation of plants. 


\section{INSECTS AND ALLIED FORMS OF LIFE-BUTTERFLIES AND MOTHS}

So much has been written in this book about the havoc wrought by insects and allied forms of life that some knowledge in regard to them and their life history may be useful. The great majority of insects are pests, but, nevertheless, there are numbers of species which are beneficial to man.

Butterflies and moths are grouped under the order Lepidoptera, that is, the order of insects with scaly wings. The butterfly differs in a number of ways from the moth. The antennæ or movable appendages which stand out from the head are plain or feathered in the moth; those of the butterfly are more or less club shaped at the tips. The two pairs of wings in the moth are fastened together by a beautiful little arrangement of hook and eye, the hook on the inner margin of one wing locking into the eye of the upper wing. Butterflies lack this provision.

Butterflies fly by day; the great majority of the moths fly by night and are attracted by light. When at rest the wings are either wrapped round the body, spread horizontally, or folded roof-like on the abdomen; they are not held in a vertical position above the body.

The life history of these insects is marvellously interesting, and is one of the most wonderful series of events in Nature. The female moth or butterfly, after mating, lays its precious eggs on trees, shrubs, crops, or young growing plants of one sort or another. 


\section{INSECTS AND ALIIED FORMS OF IIIFE}

The eggs soon hatch with the warmth of the air and sun, and tiny caterpillars appear. At first they are so small it is with difficulty they can be distinguished from the eggs. However, they soon wake up and begin devouring the leaves and tender shoots of the plant on which their parent has glued her eggs. Eggs are not laid on plants at random. The parent knows instinctively the species of plant her children will thrive upon. In this selection she never makes a mistake. The caterpillars feed heartily and grow rapidly. The skin does not grow with the body, as is the case with animals and birds; it has to be shed at frequent intervals. The old skin splits open at the back of the head, and the caterpillar draws its body through the rent. The most difficult part of the process has yet to come. The caterpillar casts out the lining of the food canal within its body. In fact, it moults its skin inside and out. After this exhausting effort it rests awhile to regain its old vigour and to allow its jaws to harden. Then it again attacks the vegetation, and eats voraciously until the next moulting time. A caterpillar's life is made up of eating and casting its skin. It moults from five to ten times, according to the length of time it remains a caterpillar. Some change into chrysalides in a month, while others take longer. The caterpillar of the goat moth, for instance, does not change into a chrysalis for three years, and during its life it has made itself 72,000 times as heavy as when it emerged from the egg. The privet moth caterpillar changes into a chrysalis in twenty-two days, and during that short time its 


\section{NATURAL HISTORY OF SOUTH AFRICA}

weight is II,3 I 2 times as great as when it was born.

A caterpillar on an oak tree was kept under observation for fifty-two days, and during that period it ate 120 oak leaves weighing three-quarters of a pound.

We all know what a greedy feeder a silk-worm is. It can be taken as an example of the eating powers of other species of caterpillars. Is it, therefore, not essential for us to carefully foster and care for all enemies of caterpillars? If, as an instance, a bird had gobbled up the caterpillar referred to on the oak tree, I 20 oak leaves would have been saved. When the caterpillar is full grown it ceases eating. If it is the larva of a moth it will spin a cocoon of silk or make a bag of some sort around itself, or else hide away amidst decaying leaves or loose mould and change into a chrysalis. If it is the larva of a butterfly it will probably suspend itself from a twig or crawl into cover and change into a chrysalis. The chrysalis of a butterfly caterpillar is usually golden in colour, whereas that of the moth is deep reddish-brown.

The caterpillar or larva has now turned into a chrysalis or pupa. It lies sleeping in its case for some days, weeks, or months, according to the species of insect and the weather. Suddenly the chrysalis opens, the top ring lifting off like a lid, and a moth or butterfly crawls out. In the interval of sleep the ugly caterpillar has changed into a lovely moth or butterfly. The insect is now called an imago, and is as big as it ever will be. At first it is weak and 


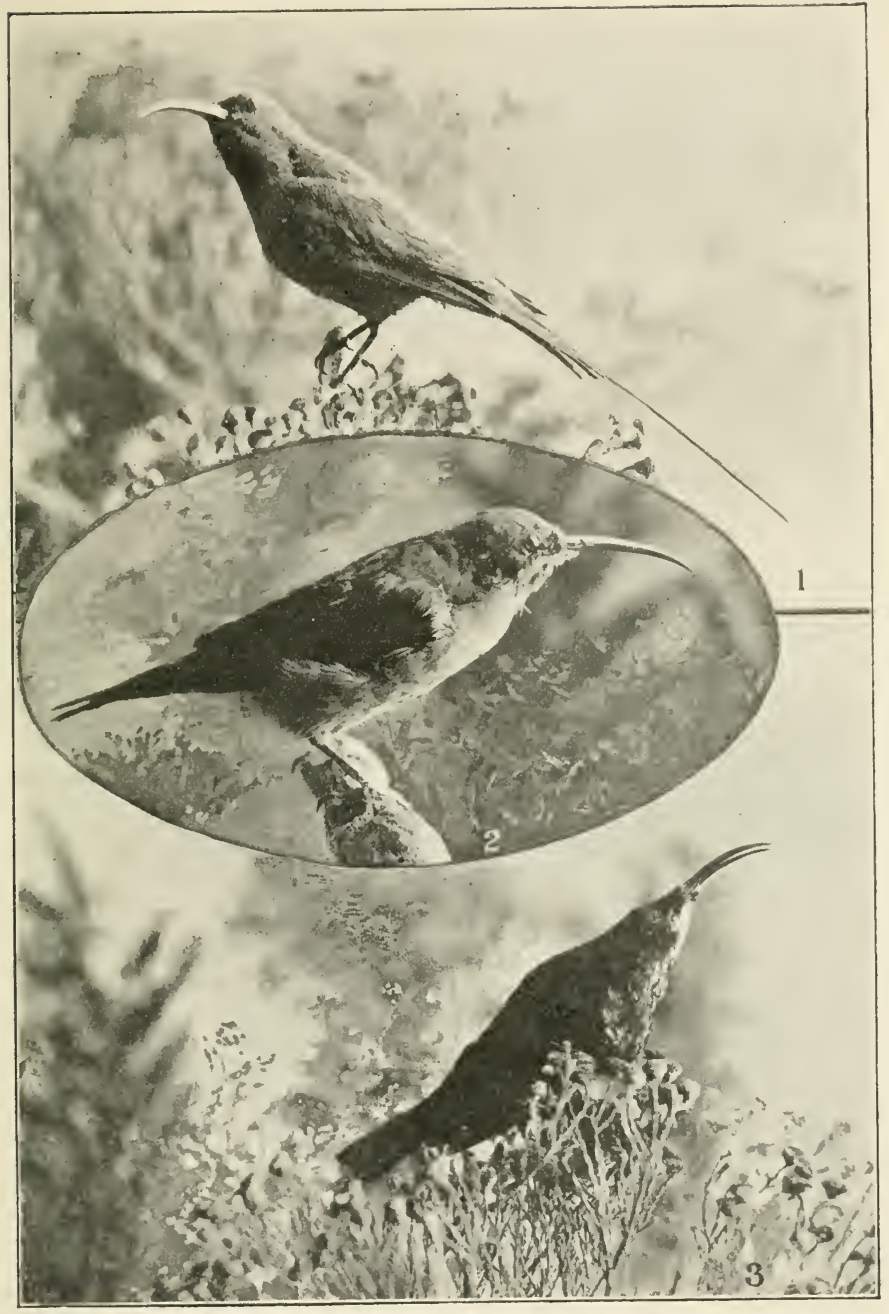

1. The cock Malachite Sun Bird (Nectarinia famosa) has brilliant metallic green plumage, and is one of Nature's most beautiful living jewels.

2. Malachite Sun Bird (female), with plumage of a sombre hue.

3. Scarlet-chested Sun Bird (Cinnyris gutturalis). The beauty of the male of this species transcends the imagination of man. 
unsteady. Its wings are small and crumpled. The juices from the insect's body flow into the veins of the wings, and they expand and dry. Presently the insect rises into the air and flies off-one of the loveliest and most marvellous of Nature's creations.

Some species of butterflies and moths live only two or three days, and do not eat at all. Others sip nectar from flowers, the butterflies by day and the moths by night, and live weeks and even months. After mating, the females deposit their eggs in clusters on twigs, leaves, bark, etc.; or on wool and fur in the case of the clothes moth. These eggs hatch into caterpillars, and so the life cycle goes on as before.

Butterflies and moths, in their quest for nectar, carry pollen and fertilise plants, and in this way they are beneficial. They, however, breed so rapidly that, if left unchecked, their larvæ; which are called caterpillars would eat all the vegetation off the face of the earth.

The cultivation of the ground by man provides good, succulent, nutritious food for caterpillars, and they, in consequence, tend to increase much more rapidly than if they were obliged to support themselves on wild plant food; hence the necessity for taking every possible measure to increase the number of insectivorous birds and bats. Ichneumon flies are very destructive to caterpillars. The fly punctures the skin of a caterpillar and deposits an egg in each puncture. These eggs hatch into grubs, which feed on the body of their host, the caterpillar. The latter usually does not die until it has changed into a chrys- 
alis. By this time the grubs have also become adult and changed into chrysalides, and at the proper time. instead of a beautiful moth or butterfly issuing from the caterpillar chrysalis, a number of ichneumon flies emerge. They fly away, mate, and the females seek out fresh caterpillar victims.

Caterpillars evolve various schemes to protect themselves against their bird enemies. They feed on the under sides of leaves, hide by day and issue forth by night; bore into trees, manufacture a nasty secretion which makes birds sick, and grow stiff hairs on their bodies; others imitate dry twigs, pretend to be dead, or frighten their enemies by assuming alarming attitudes.

Birds have their likes and dislikes. Some birds feed on certain species of caterpillars which other kinds of birds will not touch. For instance, the cuckoos feed very largely on hairy caterpillars which the majority of other birds will not eat.

Sometimes caterpillars multiply so alarmingly that they swarm in uncountable multitudes and strip forest, veld, and farms bare, leaving famine in their wake. In I9I9 the army moth caterpillar stripped the veld as bare as a road over wide stretches of country in South Africa. The army moth flies by night, and night jars and insectivorous bats are their chief enemies; yet little or nothing is done to protect these night-flying birds and mammals.

Most species of moths die after one, or at most two, batches of eggs have been laid; but some kinds hibernate during the winter. Eggs and chrysalides 


\section{NATURAL HISTORY OF SOUTH AFRICA}

also remain dormant throughout the winter months. On the advent of warm weather the eggs hatch and the chrysalides burst, and moths and butterflies emerge to increase the race.

"Devoured by worms, like Herod, was the town, Because, like Herod, it had ruthlessly Slaughtered the innocents. From the trees spun down

The canker worms upon the passers-by, Upon each woman's bonnet, shawl, and gown,

Who shook them off with just a little cry: They were the terror of each favourite walk;

The endless theme of all the village talk."

LONGFELLOW.

\section{BEETLES}

Adult beetles and their larvæ are almost if not quite equal in their destructiveness to the caterpillars of moths and butterflies. Hosts of species of beetles attack and devour plant life. There are others, however, which are known as carnivorous beetles. These feed voraciously on insect life-largely on the beneficial ant.

Beetles are grouped under the order Coleoptera. They possess a pair of horny wing-covers known as elytra. They meet in a straight line down the back. Beneath these hard and usually shiny wing-cases are a single pair of transparent wings. The mouth parts are adapted for biting.

The life history of a beetle is, first the egg, then 


\section{BEETLES}

the grub, chrysalis, and adult beetle. 'The eggs are laid in crevices in the bark of trees, in punctures made by the insect, on twigs, in the ground, in balls of dung, in seeds, grain and various other foodstuffs, animal skins, and dry flesh.

The grubs of beetles differ from the caterpillars of moths and butterflies, and are usually white or coppery white. As soon as the grubs hatch from the eggs they begin their career of destructiveness. Some kinds bore into wood and feed on it. Great numbers of species pass their lives underground, feeding on root crops and the roots of all manner of plant and tree growth.

One of the weevils lays its eggs in mealies, mealie meal, and other grain. These eggs hatch into tiny, yellowish-white grubs or maggots, which feed on the grain and meal. When the grub is full grown it, like the caterpillar, changes into a chrysalis, and in due time emerges from its case a fully-developed adult beetle.

Unlike butterflies and moths, adult beetles, with the exception of the comparatively few predaceous species, feed greedily on vegetation. For instance, the Colorado or potato beetle is a much dreaded pest. If not kept strictly in check, it increases so rapidly that it eats off the potatoes to the last plant.

The damage done to man directly and indirectly by beetles and their larvæ is colossal. The grubs of some of the wood-boring beetles live, in the grub condition, in trees for several years before finally changing into beetles. During all this period they 


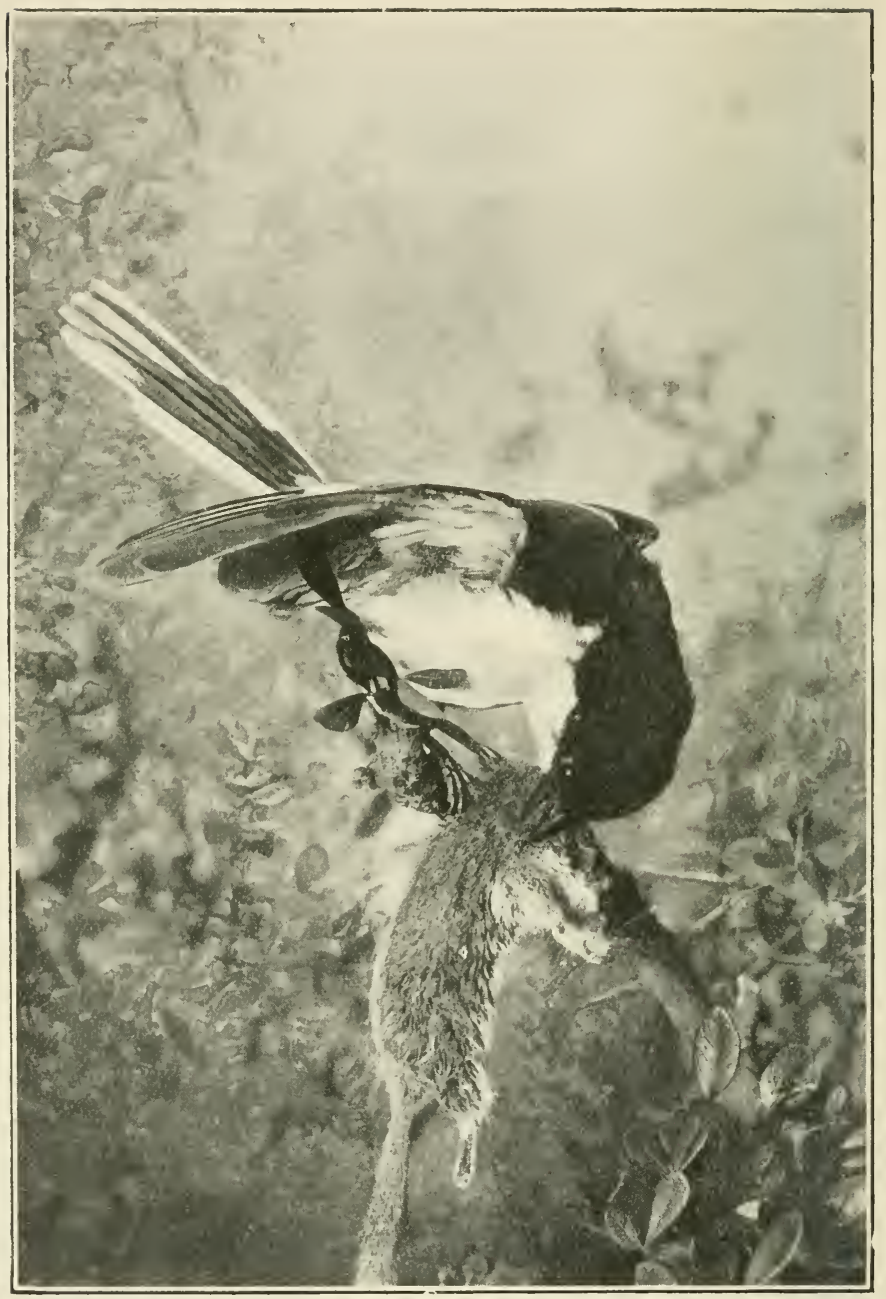

A Fiscal Shrike, or Butcher Bird (Lanius collaris), in the act of killing a Cape Dormouse (Graphiurus murinus).

The Dormouse preys on the young and eggs of birds.

This familiar shrike, which is much persecuted by boys, eats various species of hairy caterpillars which no other species of bird will touch. 
are tunnelling through the living wood, and slowly but surely destroying the health and life of the tree.

The grubs or larvæ of beetles are more formidable enemies of man than the caterpillars of butterflies and moths in one sense, and it is this. They, as a general rule, live out of sight in the interior of the substance they prey upon, or hide in the soil. Consequently man cannot readily reach them with his artificial insect exterminators, and their natural enemies, the birds, find it difficult to get at them. Therefore those comparatively few species of birds which seek out and prey on the grubs of beetles should be afforded a double measure of protection by man. Among the predaceous beetles the lady-birds (Coccinellide) and their larvæ do good service by feeding on aphides and scale insects. Several other families of beetles and their larvæ feed on insects and allied forms of life, notably the tiger beetles (Cicindelide), ground beetles (Carabide), water beetles (Dytiscide). The weevils, of which there are a large number of genera, are the most destructive of all the beetle tribe to vegetation and foodstuffs. They attack and destroy all kinds of plants in a variety of ways. The apple blossom weevil devours the flower buds of apple trees wherever apple trees are grown. Birds gather to feed on these pernicious beetles, and man, concluding the birds are the offenders, foolishly destroys his feathered friends. Other species of weevils attack stored corn, rice, wheat, etc. During the Anglo-Boer War some shortsighted, greedy speculators in Maritzburg cornered thousands of bags of mealies. When the price went

VOL. I. 


\section{NATURAL HISTORY OF SOUTH AFRICA}

up as the result of this dishonest deal, those robbers of the people's money got a most unpleasant surprise. The entire stock of grain had been destroyed by weevils.

Birds are Nature's principal enemies of beetles.

\section{FLIES}

Flies are distinguished from all other insects by possessing only two wings. The second pair are rudimentary, and are reduced to stalked knobs called balancers.

The mouth parts are modified for sucking and piercing.

Their life history is the same as that of beetles and butterflies, viz., the egg (ova), maggot (larva), chrysalis (pupa), and adult fly (imago). A few species of flies incubate the eggs within their bodies; the majority produce eggs.

With two or three exceptions, the flies of the order Diptera are a terrible curse to man. The common house fly (Musca domestica) is a world-wide pest. It breeds chiefly in fresh stable manure (horse, mule, and donkey manure). Failing this, it will breed in human excrement, moist decaying garbage, etc. Its whole life history from egg to mature fly averages fourteen days. The eggs hatch a few hours after being laid; the maggots feed greedily for eight days 


\section{FLIES}

and then change into chrysalides. After five days a full-grown fly emerges from the chrysalis. A female fly lays a batch of about 120 eggs, and often a second lot before she dies. Flies, which are born in the spring, will often survive until the cold of late autumn kills them. Apart from being an intolerable nuisance in houses and to stock animals, the house fly is an agent in the spread of disease germs amongst men and domestic animals. It carries the germs of diseases on and in its body. It is one of the foulest of feeders. Unfortunately for men, its digestive juices are not sufficiently antiseptic to kill disease bacteria swallowed with its food. They, consequently, pass out of it in its excrement alive. Fly specks are the excrement of flies, and they usually teem with living disease germs. Wild birds feed eagerly on the fly in every phase of its life history. Many species of birds devour the maggots and chrysalides, while others take the adult fly on the wing.

The maggots of the flies known as gall midges (Cecidomyide) burrow into the tissues of plants and give rise to galls.

The crane flies or daddy long-legs (Tipulide) are notorious pests. Their larvæ or maggots, which are known as leather jackets, prey upon the roots of plants.

The female gadfly (Talamide) sucks the blood of horses and cattle, and in so doing carries disease from one to another. The maggots live in damp earth, and are preyed upon by partridges, thrushes, robin chats, and other birds. The hairy, bee-like botflies 
(Estride) lay eggs on the hair of horses and other large animals. These eggs are licked off and swallowed by the animals, and the larvæ which hatch from them live as parasites in their hosts' stomachs. The larvæ are known as bots. The larvæ of some species live in the nasal and ear cavities of large animals, and cause their victims acute distress.

The warble flies (Hypoderma) are another pest to large animals. The female punctures the skin of her host and lays an egg. A grub hatches from the egg and passes its larval span of life beneath the skin of the animal, living on the juices of its host all the time. When adult it burrows out, drops to the ground, and changes into a chrysalis. The grub of the botfly, when adult, passes out of its host with the stallings, and also changes into a chrysalis on the ground. Partridges, guinea-fowls, starlings, and some other species of birds break up the droppings of animals and eat these grubs and any worms or other noxious forms of life they might contain. By scattering the excrement of animals they also render excellent service by preventing other species of flies from breeding in it; and by exposing it to the drying heat of the sun, any eggs of parasitic pests it might contain are shrivelled up and destroyed.

The tse-tse flies of the genus Glossina inoculate man with sleeping sickness, and domestic animals with a disease known as nagana or tse-tse fly disease. The maggots are produced alive, and are full-grown when born. They are usually deposited in damp, loose, loamy, leaf-strewn soil under bushes, where 


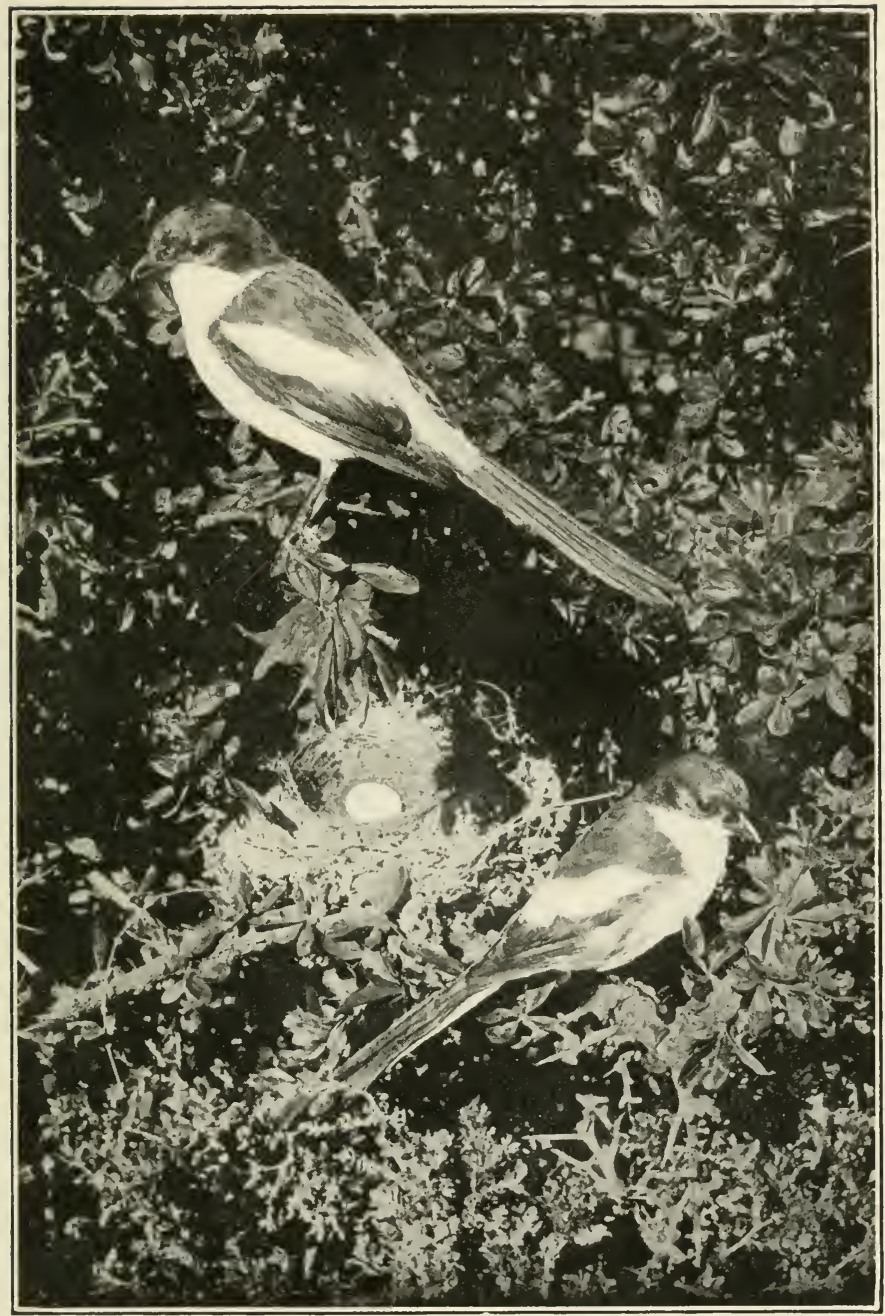

Fiscal Shrike, or Butcher Bird (Lanius collaris), with nest and eggs. This familiar shrike is of high economic value, notwithstanding its occasional habit of killing small birds temptingly exposed in cages. The author has tested it with the Mantis, or Hottentot God, Lady-Bird Beetle, and other beneficial insects, and has found it does not eat them. 


\section{NATURAL HISTORY OF SOUTH AFRICA}

they change into chrysalides, and eventually issue forth winged flies to feed on the blood of man and beast, and incidentally carry deadly infection to them.

Here, again, the bird comes to the rescue. The one all-important consideration of a bird is to find enough food for itself and its young. Consequently birds know exactly where to seek for their prey. The naturalist and trained collector are mere tyros in comparison. Thrushes, partridges, guinea-fowls, and a number of other species of birds know when and where the tse-tse flies produce and hide their young; and they assemble from all over the neighbourhood to scratch them up and devour them. Man, in his stupidity, greed, and selfishness, armed with gun and dogs, drives forth the birds and shoots them down. After learning that game birds, such as partridges, pheasants, guinea-fowls, and some others, are saving countless multitudes of men and animals from getting infected with sleeping sickness and nagana, as well as other diseases, would anyone calling himself a man go deliberately forth to slay these allies of the human race? We think not.

While men in authority struggle one with another for place and power, the people of the world go on suffering from preventable diseases and preventable poverty. When a war is on, money is raised and spent as prodigally and recklessly as water; but when men of science ask for money to be spent on fighting the many foes which incessantly attack the human race and check its evolution and expansion, they are either 
BEES, WASPS, HORNETS, ANTS, ETC.

ignored or money is doled out with a niggardly and hesitating hand.

While ambitious men wrangle, scheme, and fight, the race suffer and perish prematurely.

The various species of flies which check the expansion of the human race are many, and space does not permit of a fuller mention of them. It is sufficient to say that birds prey incessantly upon them in all the three phases of their development-maggot, chrysalis, and adult fly.

\section{BEES, WASPS, HORNETS, ICHNEU- MON FLIES, SAW-FLIES, ANTS, ETC.}

These insects are grouped under the order Hymenoptera. They possess four membraneous wings, the hind ones being smaller than the fore wings. Mouth parts are formed for biting and sucking. The end of the abdomen is usually provided in the female with a sting, a piercer, or a saw. The life history is the egg, grub, chrysalis, and adult insect. Bees are eminently useful in fertilising flowers. They feed on nectar. The honey bee provides man with honey and wax.

The typical wasps and hornets feed their grubs on other forms of insect life. They build nests of mud or papery material, or make burrows in the earth. An egg is laid at the bottom of each cell, 
and the mother wasp or hornet captures small caterpillars, various other larvæ, and spiders. These she paralyses with an injection of venom sufficient to render them comatose for a prolonged period, but insufficient to kill them outright. The cell is filled up with the victims and then sealed. The grub which hatches from the egg feeds on the food provided until it is adult. It then goes through the usual change, and emerges a winged wasp or hornet. The parent knows instinctively the exact quantity of food to provide for her larva to last it until it is fully grown.

Hornets and wasps are generally claimed by entomologists to be beneficial to man. This is only partly so. A careful examination of the nests of the mason wasp extending over a period of years has convinced me the bulk of their victims are spiders. Spiders feed on various insect pests, and render great service to man. They capture large numbers of adult winged insects. Each female of these victims of the spider would have laid hundreds of eggs. Therefore one female adult insect killed by a spider equals in economic importance a hundred and sometimes a thousand larvæ.

The solitary wasps, however, which make burrows in the ground, prey largely on caterpillars and other destructive larvæ. The wood wasps and saw-flies puncture plants with their ovipositors or saws, and deposit their eggs in the holes thus made. The grubs burrow into the tissues of the wood, and feed on it.

Some grubs, notably those of the saw-fly, feed 264 


\section{WHITE ANTS}

openly on leaves, or form galls on twigs and pass their lives therein.

We know of no birds which prey on the typical stinging wasps and hornets, but numbers of birds feed on the destructive saw-flies. The woodpecker digs the larvæ out of their hiding places in the wood with its sharp, hard bill.

Ichneumon flies render good service to man by using caterpillars as hosts for their larvæ.

Ants are highly valuable as insect destroyers. Some species are a pest in dwellings, but, with very few exceptions, ants are of considerable economic value. Some kinds attack and destroy insect pests on and in the ground, while others seek them in the herbage and trees.

\section{WHITE ANTS}

THE termites, or "white ants," as they are popularly termed, are not ants at all. They are grouped under a separate order, viz., Isoptera. Some species build mounds and others live underground. They feed on dead, dying, and diseased vegetation. Some species attack and destroy living vegetation, such as the roots of shrubs and young trees, and play havoc with the woodwork of houses, timber, fencing poles, stacks of hay, forage, etc. Their ravages in South Africa constitute a severe handicap on the people.

Birds are the chief enemies of these destructive 
pests. When the fertile winged males and females issue forth to establish fresh colonies, the birds assemble and feed greedily on them. After rain the worker termites are usually active on top of their mounds, adding to them. When thus exposed they are a ready prey of birds. Our feathered friends of nearly every species are incessantly hunting this pest in the air, amidst dead and decaying leaves, on tree trunks, behind loose bark, and its various other lurking and feeding places. Among game birds, partridges, guinea-fowls, and quails are immensely useful as termite destroyers.

\section{LOCUSTS}

All the locusts (Locustide) are vegetable feeders. There are a large number of species. Some kinds, such as the migratory locust, often assemble in vast swarms and strip the country of vegetation. Locusts lay eggs in the ground. These hatch into small, wingless locusts. They live on the ground and develop wings when adult. In some species the wings do not mature.

The Locustide include all the long-horned grasshoppers.

The short-horned grasshoppers (Acridide) are also vegetable feeders, and both they and the locusts are pests. Some species of tree grasshoppers attack and destroy caterpillars, but the good they do in this 266 


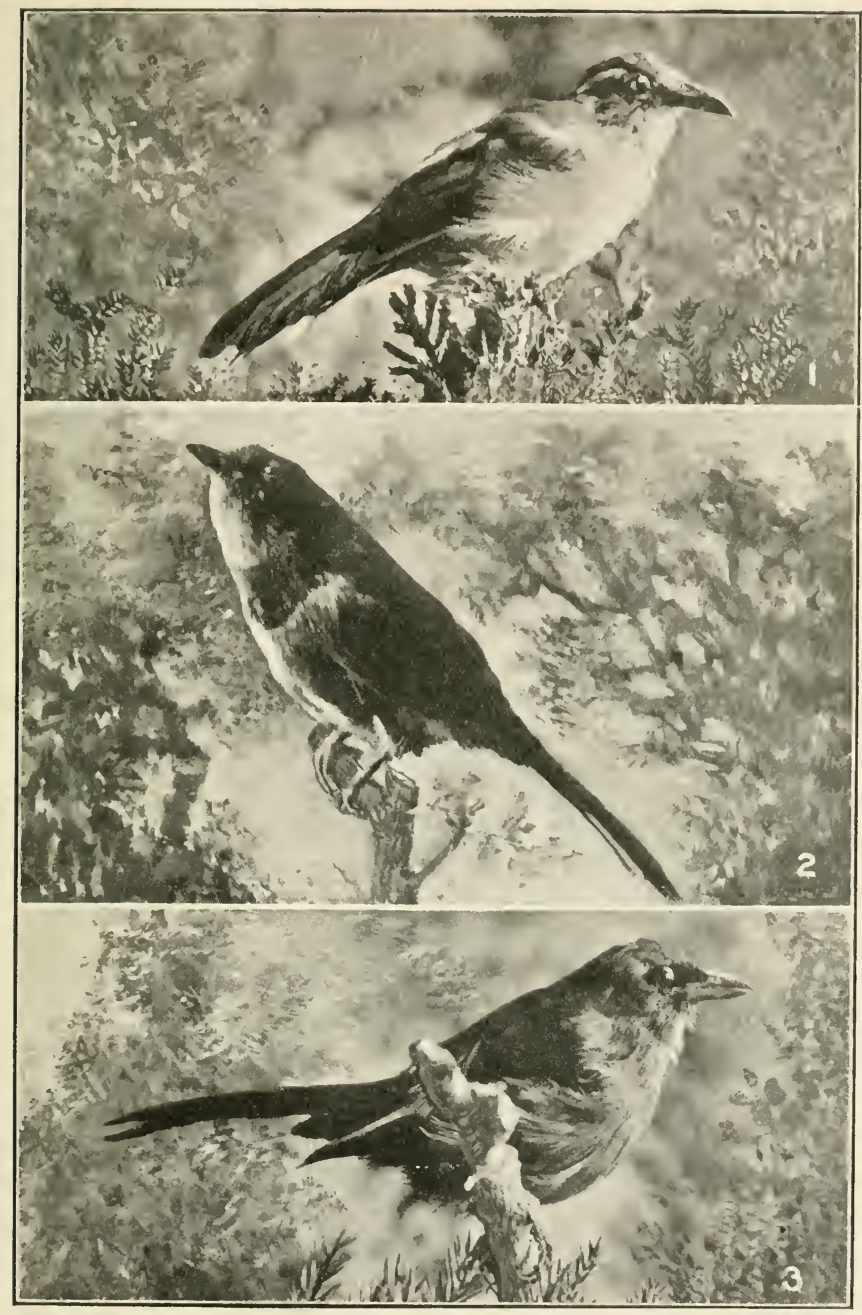

1. The Black-headed Bush Shrike (Telephonus senegalus) which helps to police the veld and scrub.

2. Four-coloured Bush Shrike (Lanarius quadricolor) with cheeks and throat of scarlet.

3. The Black and Crimson Shrike (Lanarius atrococcincus) inhabits the bush country from the Orange and Vaal rivers to Angola, and gives the insects of those territories a bad time.

They are conservators of the bush and scrub lands. 
way is of little value. Hundreds of species of birds feed upon locusts and grasshoppers, and if it were not for our feathered allies these pests would make stock rearing and agriculture impossible.

Guinea-fowls, partridges, and pheasants dig up the locust eggs and feed on them.

\section{TICKS}

There are a large number of species of ticks (Acari). They are parasitic on animals, and feed on their blood. All ticks pass through the following stages :-

I. The egg.

2. The larva.

3. The nymph.

4. The adult.

The adult female, gorged with the blood of her host, drops to the ground and, crawling into a tuft of grass, a crevice, under leaves, etc., deposits a large coherent mass of eggs, and soon afterwards dies. The number of eggs laid by a single tick varies from about 2,000 to $\mathrm{r} 8,000$, according to the species. The larvæ have six legs. They crawl up the stems of grasses and other plants and gather at the top in clusters, and wait for an animal to brush past. They cling to the hair of its legs and body, and fasten upon the skin and feed. After distending themselves with blood, they moult and change into nymphs with eight legs. 


\section{TICKS}

The nymph, after feeding on the blood of the host and increasing its size, moults its skin and appears as a sexually mature tick. The female is fertilised by the male while she is still small. She sucks the blood of her host until she becomes greatly distended. She then lets go her hold and falls to the ground and proceeds to lay her eggs.

Ticks are the chief agents in spreading stock diseases. If ticks were exterminated we should practically stamp out stock diseases. Apart from the terrible losses of stock animals by infection spread by ticks, these terrible pests cause severe irritation, loss of blood, and consequent loss of condition in animals.

Birds feed upon ticks in every phase of their life history. Quails, larks, and other birds seek out the clusters of eggs and devour them. Other species of birds pluck ticks from their host or feed upon the gorged females on the ground. Numbers of birds, chiefly starlings, associate with cattle in order to secure these blood and egg laden female ticks when they fall from the cattle. A single female tick is indirectly capable of infecting an entire district in a short time with one of the many cattle plagues.

Every gorged female tick eaten by a bird is the potential parent of from 2,000 to 18,000 ticks, each individual of which may be capable of infecting a stock animal with a highly virulent disease. It will therefore be seen what an important part the bird plays in stock rearing. 


\section{MOSQUITOES}

OF the many insect pests which plague mankind, the mosquito is by no means the least. The female mosquito lays its eggs in water. Some species deposit their eggs on the surface of the water in adherent clusters, while others (anopheles) lay them singly. Stagnant and sheltered pools, ponds, ditches, marshes, and water in tubs, old tins, etc., are preferred, because (I) any disturbance of the surface by wind, or motion of the water in running, prevents the larvæ from coming to the surface to breathe ; (2) stagnant water contains an abundant supply of the minute vegetable and animal organisms on which the mosquito larvæ feed. They do not breed in brackish water. Each female mosquito lays about 300 eggs at a sitting, and if it survives its enemies it will lay several more batches before the cold of winter kills it. A few hours after being laid the eggs hatch. The larvæ are small blackish creatures, more or less similar in shape to a caterpillar. They are obliged to come to the surface of the water every few minutes to breathe. Advantage is taken of this fact to cover the water with a thin film of paraffin, which stops up the breathing tube of the larva and kills it. After about ten days the larva or wriggler changes into a pupa or chrysalis. If the water remains at a suitable temperature, the pupa, in about twenty hours, finally comes to the surface and rests there, and from it a fully-developed mosquito emerges and flies away. After feeding and mating, 
the female goes to the nearest collection of stagnant water and lays her first batch of eggs. On the advent of winter the great majority of mosquitoes die, but a sufficient number to carry on the race survive in dark, warm crevices, caves, cupboards, and other sheltered places. The female mosquito possesses a most efficient apparatus for piercing the skin of its host and drawing out its blood, on which it lives. The instrument is a pointed proboscis which serves the double purpose of piercing the skin and sucking up the blood. When this sharp instrument is thrust into the tissues of the mosquito's victim, and a droplet of saliva is injected into the bottom of the wound for the purpose of causing the blood to flow more freely, it is the irritation of this saliva which causes itching and redness in the human subject.

In the male mosquito the proboscis is comparatively short, and is not in other ways adapted for piercing the skin of an animal or man. The males feed on the juices of plants, as do the females when blood is unobtainable. They prefer blood, however, to any other kind of food.

Apart from mosquitoes being an annoying, biting, sleep-dispelling pest, they inoculate men, animals, and birds with virulent diseases. The mosquito is the agent which spreads malaria and yellow fever. The female mosquito sucks the germ or parasite laden blood of a sick man or beast. These disease-producing parasites accumulate in the saliva of the mosquito, and when it punctures the skin of its host, it injects a droplet of this infected saliva. The parasites soon find 
their way into the victim's blood, where they multiply rapidly. The mosquitoes have many natural enemies. The wrigglers are preyed on by small fish, the larvæ of dragon flies, water beetles, and other aquatic creatures.

Authorities on mosquitoes and mosquito-borne diseases, in mentioning the natural enemies of mosquitoes, either omit to mention birds or speak of them as being of no practical value as mosquito destroyers. On the contrary, birds feed greedily on adult mosquitoes. All species of swallows, martins, and swifts prey upon them on the wing when they begin to fly at sundown. The night jar feeds upon them all night. The warblers, of which there are a large number of species, search them out in their lurking places during daylight hours, and dispose of vast numbers. Many species of fly-catchers join forces with the swallows in capturing these pests on the wing, and continue their onslaught until it is too dark for them to see.

\section{APHIDES, OR PLANT LICE}

THese small insects live on the juices of plants, the skin of which they pierce preparatory to sucking out the juices. They may be seen clustered on the buds and tender shoots. Warblers and other small birds feed freely on these pests. They also utilise them as food for their nestlings. 


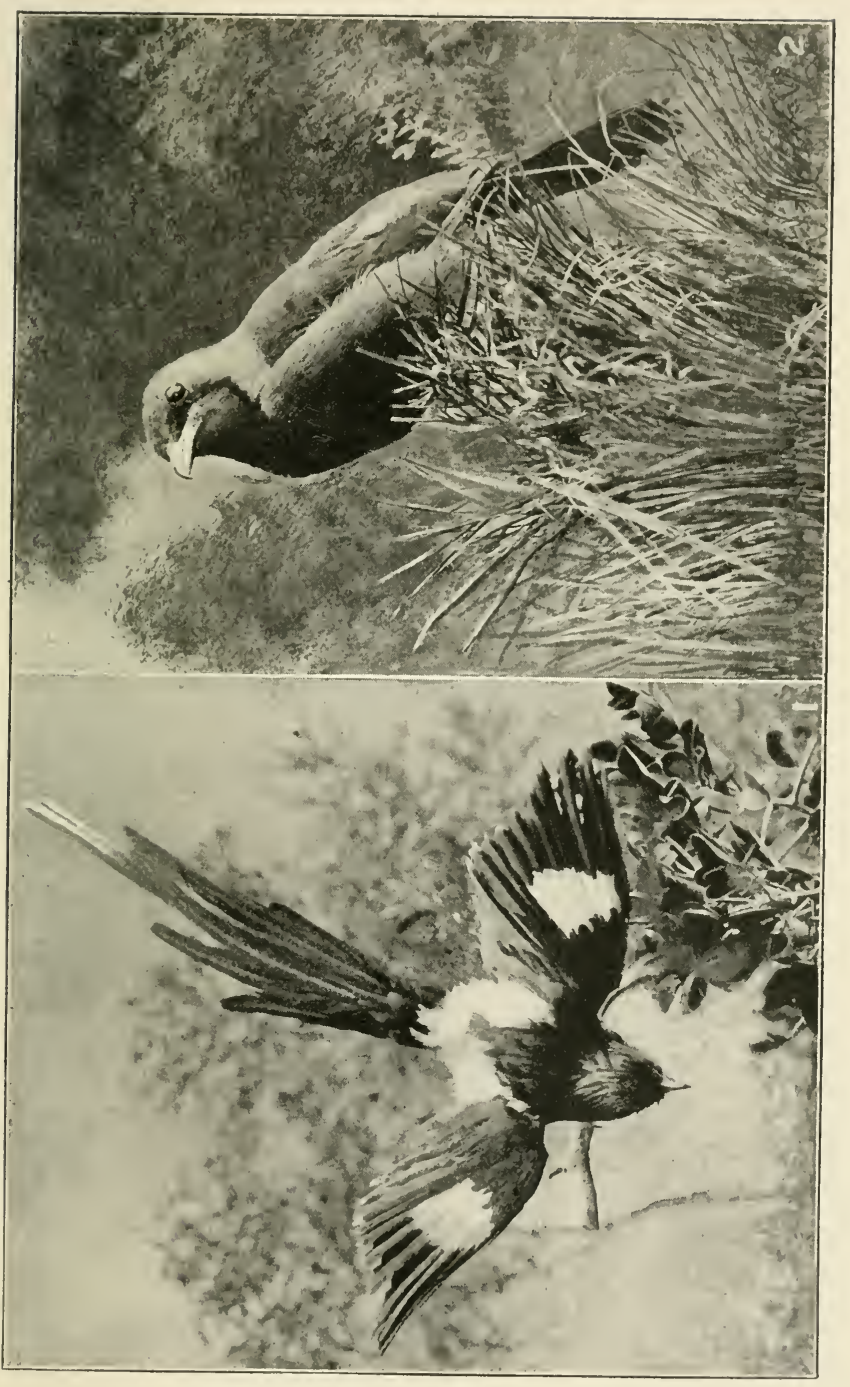

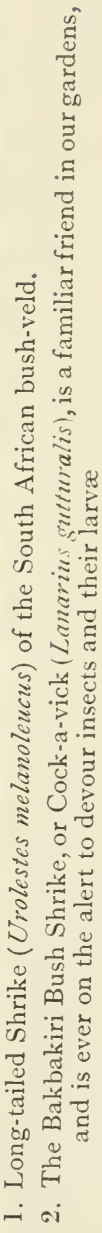

VOL. I. 
One aphis can become the parent of billions during her brief life of a summer season.

I have found thousands of plant lice in the stomachs of warblers. When large animals trouble us we can shoot or poison them, but we are practically powerless against the insect hosts without the aid of our feathered friends.

\section{TERRITORIAL HABITS IN BIRD LIFE}

WhEN we say a bird or animal is territorial in its habits, it means it restricts its range to a certain area or territory, and regards it as its own by right of conquest in precisely the same way as the human race has done from time immemorial.

Some species of animals and birds secure territory and hold possession of it for the remainder of their lives, or until driven out by stronger rivals. For instance, a troop of chacma baboons will take possession of a portion of a range of stony hills, a kloof, or rugged isolated mountain, and regard it as their own. A troop of vervet monkeys will do likewise with a certain area of bushland. Birds, such for instance as the well-known fiskal shrike or johnny hangman and his wife, are strictly territorial, and remain so during their lifetime, and will not tolerate rivals of their own species on their hunting grounds. 


\section{TERRITORIAL HABITS IN BIRD LIFE}

Other species of birds are territorial only during the nesting season, and when the young have been reared they associate in flocks with others of their own, and even different, species. On the approach of .

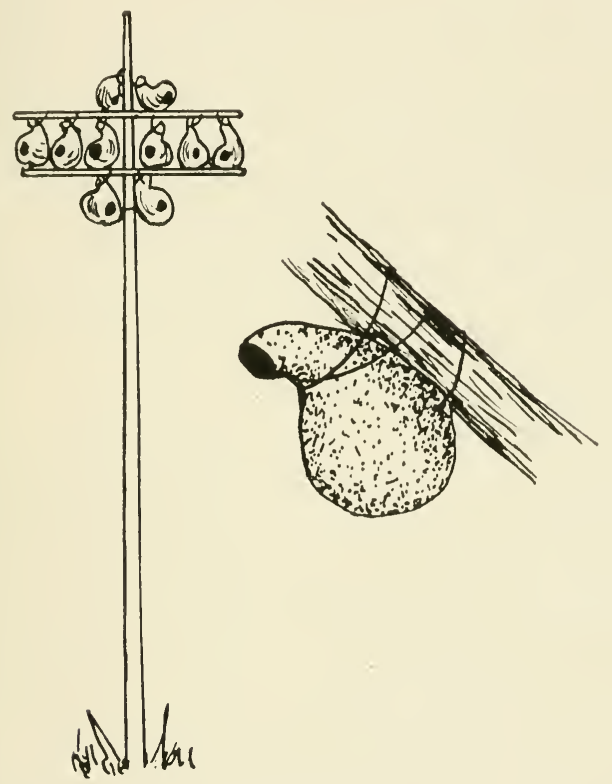

Gourds or Calabashes on poles, or tied to the branches of trees, are suitable for nesting in. They are waterproof and warm.

the next nesting season the sex instinct begins to assert itself in the male bird first; he forthwith leaves the flock, selects a suitable site, and with song and the display of his newly acquired nuptial plumage, seeks to attract a mate. Every hen bird he sees is courted, until eventually one favours him, and the 
nest building proceeds. With others, the sexes pair off before the flock disperses, and they at once seek out a suitable locality for rearing their family. The factors which dominate the birds are :-

I. A favourable aspect for the nest.

2. An adequate food supply.

3. A site as free as possible from enemies.

Often several pairs of birds build their nests in the same locality; others in colonies. When this occurs the birds know beforehand that the immediate neighbourhood contains ample food for the young of them all.

The wattled starling, for instance, discovers where a swarm of migratory locusts have laid their eggs, and they also know when those eggs will hatch. The birds forthwith build hundreds of nests in the immediate neighbourhood, and when their eggs have hatched there is an abundance of food for the nestlings and parents in the shape of young locusts. In this way Nature provides food for the young birds, and at the same time seeks to prevent the locusts increasing unduly in numbers. Unfortunately, although these immensely valuable birds are protected by law, their nests are so accessible that Kafirs and others of nondescript breeds collect the fat nestlings in thousands for food. I have seen white men and their sons deliberately shoot into flocks of these valuable allies of ours and kill and wound hundreds of them.

The territorial habit is determined mainly by the 


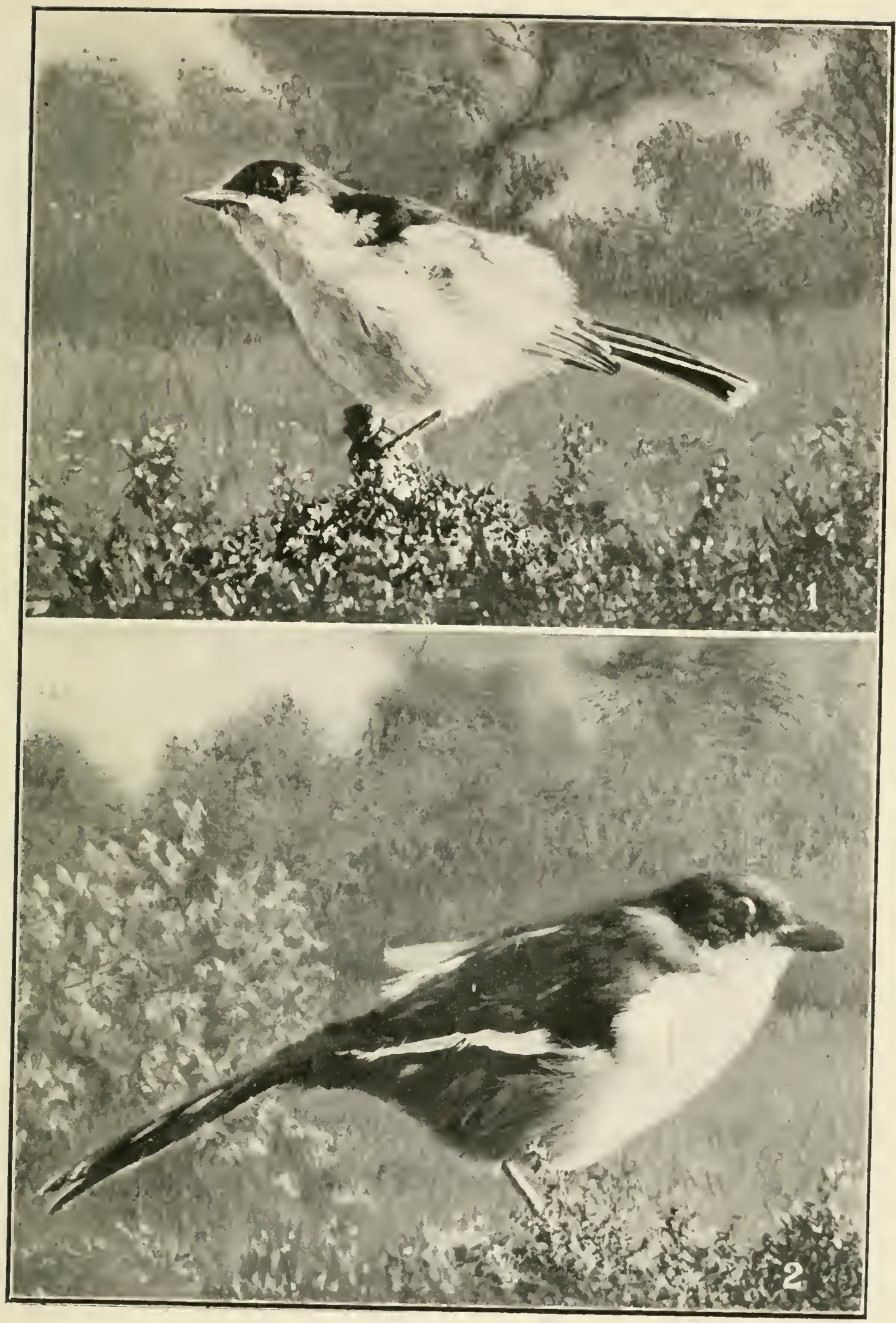

1. Lesser Puff-back, or Snowball Shrike (Dryoscopus cubla), so-called because the male puffs out a mass of snowy white feathers from the lower part of his back.

2. Greater Puff-back Shrike, or Bonte Canaribyter (Dryoscopus fermugineus), which creeps through the tangled scrub. These shrikes prey upon insect life amidst the foliage of trees and on the ground. 
food supply in any given area. It is a matter of the survival of the fittest. The size of the territory is in relation to the quantity of food required for the sustenance of a pair of birds and their young. A pair of fiskal shrikes will often be content to own one small garden plot, finding in it ample insect life for their needs.

Out in the arid veld in drought-stricken districts there is often only one pair of birds inhabiting a comparatively large territory. In a certain dry district I noticed there was one pair of fiskal shrikes to about ten morgen of land.

Often, owing to a scarcity of nesting sites, birds are forced to congregate in numbers in small areas. In these instances long journeys for food are often necessary. Others are naturally sociable in their habits, and build their nests in proximity to one another for preference.

It has been asserted that the brilliant plumage of many male birds of territorial habits, such, for instance, as the sun birds, are warning colours, viz., so that, perched on a bush, the owner of the territory will be conspicuous to all and sundry who may have any inclination to intrude. The weakness of this theory, however, is that there are as many species of birds of beautiful plumage which are not territorial as there are of those which have this habit. Birds, the males of which take on beautiful plumage only on the approach of the nesting season, will be found to be the species which are polygamous, or which have a different mate each season. There is, consequently, a definite object 
in the male bird being as beautiful as Nature can make him. Nature's aim is to carry on the species, and at the same time eliminate the unfit.

\section{PROTECTION OF CROPS AND FRUIT WITHOUT DESTROYING BIRDS}

OUR energies should be directed to the prevention of unnecessary destruction of bird life. The reduction of birds by man is prompted by various motives and desires :

I. Sport.

2. Food.

3. Insufficient knowledge in regard to their place in the scheme of Nature.

4. Mistaken beliefs in regard to their habits.

5. Brutal and ignorant lust for killing defenceless creatures.

6. The demand by women for plumage.

7. The craze for making collections of skins or eggs.

Many species of birds do considerable harm to the products of man's toil and industry under certain circumstances and conditions ; but from long experience in various countries it is now established that birds should only be killed as a last resort, as, for instance, when the seed-eating species, known as 


\section{NATURAL HISTORY OF SOUTH AFRICA}

"vinks," attack the ripening grain in vast flocks. It must never be forgotten that, with very few exceptions, seed-eating birds prey largely on insect life and feed their young on it, consequently it will usually prove more economical for us to take intelligent measures to protect our newly-sown seed and our ripening crops other than by the old method of destroying the birds. If you grudge your bird labourer his hire, or if you

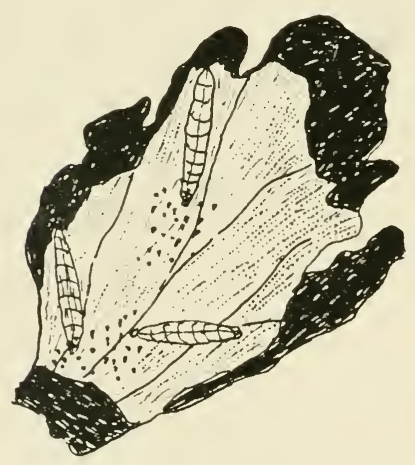

A Leaf blighted by small caterpillars. think he takes too large a wage for the services he renders, then outwit and scare him off when he comes for his pay, and only take extreme measures as a final resort.

To prevent birds eating the newly-sown seed in gardens, dress it with red lead. Place the seeds in an earthenware basin and cover them with water, stir well, and drain off the water. Then put powdered red lead in a tin sprinkler, such as an old Keating's insect powder tin, and thoroughly dust the wet seeds with the red lead, and stir and turn the seeds vigorously. Sow the seeds as soon as dry. The red lead method is useful for any kind of smooth-skinned seed which is not too small. Sprinkling seed with paraffin is another method often used. When the plants appear above ground, black threads may be stretched lattice fashion on pegs 6 inches high across 


\section{SCARECROWS AND VARIOUS DEVICES}

or along the rows and beds. Small mesh netting is better.

Birds often attack buds and seedlings because of a scarcity of water. See that water is available for their use in your garden. With a little time and patience, netting can be made in the home. A Kafir will soon learn how to make it. The netting should be oiled with castor oil to preserve it. If oiled properly it will last for years.

When your plants are in the seedling stage they may be saved from attack by exposing food for the birds in suitable places. Seed-eating birds are very fond of finely-crushed mealies, Kafir corn, or coarse mealie meal, and this provender, surely, is cheap enough. The object to attain is to encourage the birds to remain in your garden at the minimum cost to yourself, for when your plants begin growing vigorously, you will need the assistance of your feathered allies against insect enemies.

\section{SCARECROWS AND VARIOUS DEVICES}

The human scarecrow is usually a failure. To make it a success it must be properly made and moved to a fresh position after dark, so as to occupy a different spot and attitude each day. Bits of string, tin, or mirror hung around it are useful.

To scare small birds the figure of a flying hawk 
cut out of soft wood or light metal is effective. By a string and ring it can be suspended from a thin wire stretched horizontally across the seed beds, so that the breeze will make it move. To be of any lasting service its position on the cross-line must be changed every two or three days. A good scarecrow can be made in the form of a revolving windmill, so balanced that it will move with the slightest breeze. At one end about six vanes can be fitted, painted shiny red and white. In the board at the other end, fit a small piece of common mirror glass. Fix this windmill on a pole a few feet above ground. When the windmill revolves, the mirror flashes bright beams in all directions over the beds, much to the terror of the birds. A petrol or paraffin tin containing a few smaller tins or pebbles may be hung in a tree and a long cord attached. The other end of the cord, when jerked, will cause the tin to rattle alarmingly.

To scare birds from orchards, firing blank charges at stated periods is sometimes employed, but this is rather expensive. What is known as an automatic clock gun has been invented and placed on the market by $\mathrm{Mr}$ John Hall, Station Road, Wigton, Cumberland, England. It is made to hang from a tree or to stand on the ground, and automatically fires off a noisy blank cartridge, firing at regulated intervals and working as regularly as a clock. It only requires a couple of minutes to recharge and shift its position each day. This does away with the expense of a human shooter. It is essential that its position be changed each day. This clock gun is 


\section{SCARECROWS AND VARIOUS DEVICES}

also highly effective in scaring birds from grain crops at the time when they take a heavy toll of the ripening grain.

Writing of a substance called "corvusine" in Farm, Garden, and Birds, issued by the Royal Society for the Protection of Birds, 23 St Anne's Gate, London, Mr E. Purcell Jones, in an able essay, says:-

"I have left until the last that form of protector (note the exact term) which I consider is of untold value to the farmer. I speak of a proprietary article which has been placed on the market under the title of 'corvusine' (the manufacturer of this is $\mathrm{Mr} \mathrm{A}$. E. Hawker, 59 Mark Lane, London, E.C.). On the Duke of Westminster's estate here in Cheshire it has been tested with the very best results. It is a combination of sundry chemicals with a harmless tarry basis, and it is used to dress the seeds before sowing. It is absolutely non-injurious to the seeds; indeed, greatly helpful, inasmuch as it effectually kills such diseases as the smut of wheat. The various soil pests give it a wide berth-to birds it is anathema. 'The makers of this article claim that its use costs about $6 \mathrm{~d}$. per acre, and I know that farmers whose seeds suffer from birds will find it the most productive $6 \mathrm{~d}$. per acre they ever spent. Now, while it is of no service in protecting the grain when it is ripe, it possesses, while the crop is growing, this immense advantage as a protector over the mechanical scarer-it prevents the birds feeding on your seeds, but it does not altogether drive them off the land, so by its means you get the inestimable services of the scavengers without having to pay 


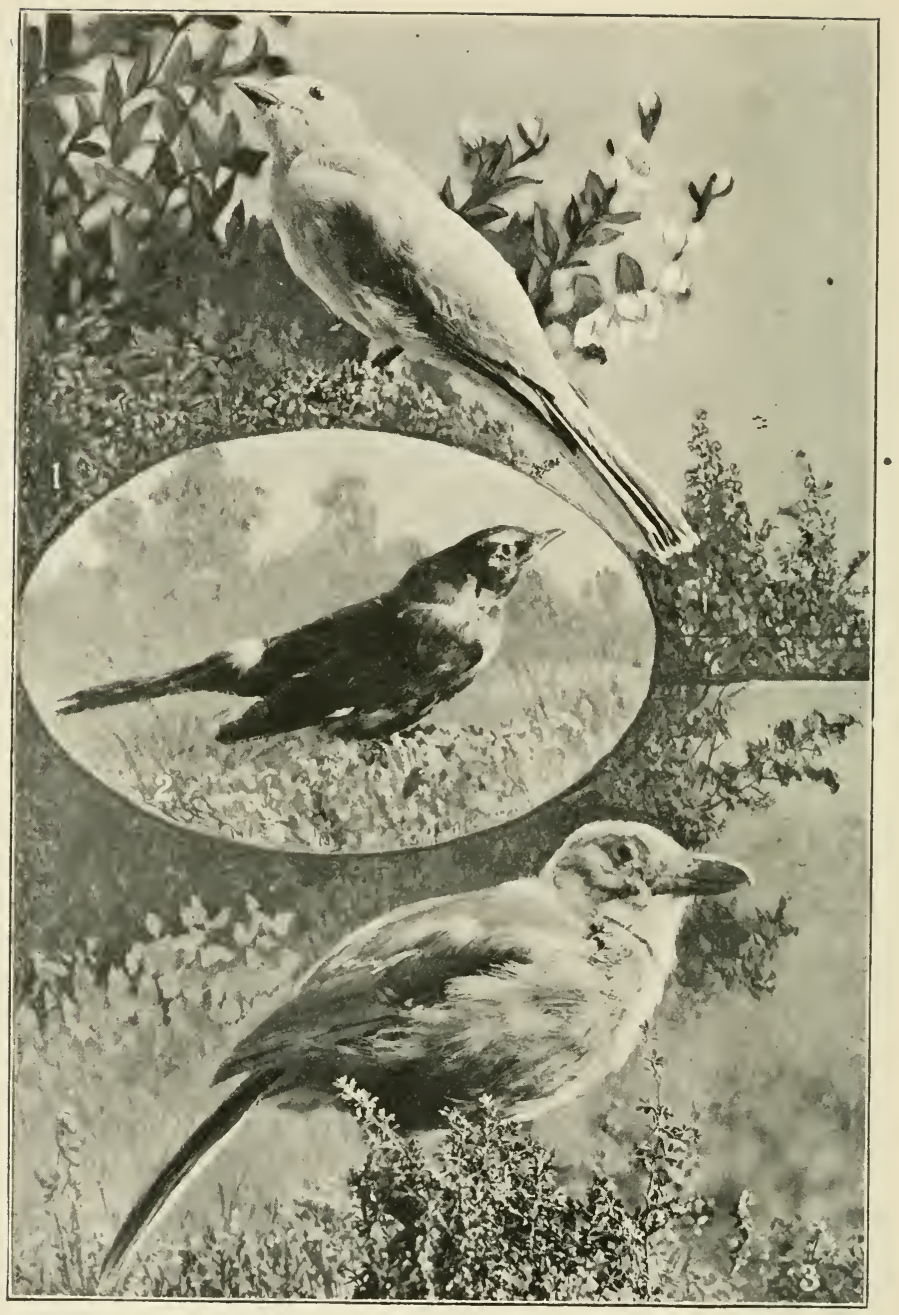

1. Grey Cuckoo Shrike (Graucalus casius), or Blaauw Katakure, of the forests and bush-veld on the eastern side of South Africa.

2. Black Cuckoo Shrike (Campophaga nigra). These Cuckoo Shrikes are inveterate enemies of insect life in the forests and bush-veld.

3. Southern Grey-headed Bush Shrike (Lanarius starki). This shrike, in addition to insects, adds young snakes and mice to its diet. 


\section{SCARECROWS AND VARIOUS DEVICES}

any wages. Have you seen a fine turnip swarming with turnip caterpillars? You know well enough the ravages of wire-worms, leather jackets, and the rest? You must have the services of the birds to keep down these pests. I have proved over and over again that starlings and other birds eat them in enormous numbers, and it is now possible to allow such valuable service to go on unrestricted and at the same time rest assured that your own seeds are safe. Similar good results are obtained by the use of 'Clark's wheat protector' (the maker of this is Mr G. B. Clark, Woburn Sands, Beds., England), which is a carbolised, instead of a tarry, preparation; this will dress something like a bushel of seed at a cost of a modest penny."

In South Africa, where native umfaan labour is so cheap, it pays to keep boys to patrol the orchards and fields with empty tins at the times when the crops are liable to be attacked by birds.

Spraying budding fruit trees with nicotine emulsion has good results. It is very lasting, and one spraying is usually sufficient to protect the buds until they burst, when they are then safe. If much rain has fallen, a second application will be needed. Birds abominate the bitter taste of nicotine. This method has been practised with great success in England by fruit farmers against the bud-eating sparrow and bullfinch.

A simple device to scare birds is mentioned by Mr E. J. Platt in Farm, Garden, and Birds. He 
"When a large area is sown down, and netting is impossible, I have found a very simple method most useful. Stretch lines of string about I 5 feet apart over the whole area, on stout stakes about 6 feet high; from these lines at intervals of I 5 feet suspend a medium-size potato 4 feet from the ground, liberally furnished with wing feathers of fowls or other such feathers; the slightest breeze sets the potato in motion, and proves a most effective deterrent. The preparation of a seed bed with a fine tilth is a great aid. The seed can then be well covered, and is not so easily found by the birds."

\section{SUMMARY}

THE most efficient and cheapest way to protect large areas has been found to be the live scarecrow, in the shape of a boy with a pair of clappers or an empty petrol tin and a drum stick. He should be the possessor of a strong voice, and ought to carry a rattle or " bull roarer" to use at intervals. A " bull roarer" is a small, flat, oblong piece of wood, to which is attached a stout cord about 3 feet long. The boy whirls this rapidly in the air. When properly manipulated it makes a roaring noise terrifying to birds. The best plan is for the boy to sleep in a hut in the centre of the orchard or field, and to begin his demonstrations before the early bird arrives. The boy should have an assistant in the form of a terrier 
dog with him. A wind-driven scaremill or crawmill has given good results. It also serves the purpose of scaring hares and bucks off the crops at night.

Empty tins and shiny pieces of glass hung in bunches from horizontal wires or from poles are good.

$\mathrm{Mr}$ Turnbull, in support of the windmill, writes:-

"Being a market gardener, I have tried many ways of protecting my crops, and find the most effective and economical is by means of a simple windmill, with a few links of chain securely attached to the spindle and an old tin shovel fastened above, so that every time the sails fly round, the chain whacks the shovel and makes the terrified birds fly in all directions. Any handy man can make one in half an hour. Any other thing the birds get used to. If a windmill were going constantly the birds would take no notice of it; but in this case sometimes all is still, then a little wind springs up and the sails fly round, the chain batters the shovel, and off the birds go. I have found it most effective and cheap, and have never had occasion to shoot a bird for many years."

Flying a hawk-shaped kite at intervals over the crops often proves very helpful. Most birds have a great dislike for glass bottles placed on or hung from sticks about 3 feet high. These could be put at intervals among the crops and shifted every day or two. Coloured rag streamers, preferably red, at the end of high poles are often employed as scarecrows.

Wrapping black and white cotton, intermixed, round fruit trees and bushes is a good deterrent. 
Birds, in avoiding the white cotton, fly against the black and get such a scare that they do not return. Muslin bags for choice fruits, such as figs and peaches, may be used. A friend has 300 small tobacco bags, and these are placed on the figs when they begin to swell. Every morning he, or a native, goes round the trees, removes the ripe figs, and replaces the bags on other figs. In this way he loses very few figs.

Fruit growers should plant sunflowers, millet, wheat, etc., in the vicinity of their orchards to provide food for birds. Many species of seed-eating birds only attack fruit when driven to do so by desperate hunger and thirst. If cheap food and water are provided, the fruit will be saved.

Ploughing up and harrowing land near an orchard will often keep numbers of birds from eating fruit. The turned-up soil will provide insects and seeds to satisfy the needs of the birds.

Fruit-eating birds are very fond of mulberries. These trees flourish in most fruit-growing districts. A few such trees may be planted in and about the orchard to provide food for birds. When mulberries are available, the birds will not touch other fruit. Various hardy berry-bearing trees and shrubs may also be planted with advantage. 




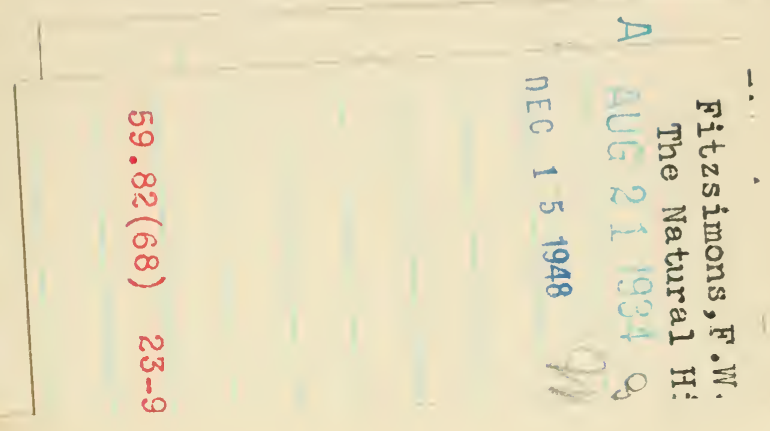


